Universidade de São Paulo

Faculdade de Educação

MARIA PAULA CORREIA DE SOUZA

O discurso expositivo sobre biodiversidade e conservação em exposições de imersão 
MARIA PAULA CORREIA DE SOUZA

\section{O discurso expositivo sobre biodiversidade e conservação em exposições de imersão}

Tese apresentada à Faculdade de Educação da Universidade de São Paulo para a obtenção do título de doutora em Educação.

Área de concentração: Ensino de Ciências e Matemática

Orientadora: Profa. Dra. Martha Marandino 
Autorizo a reprodução e divulgação total ou parcial deste trabalho, por qualquer meio, convencional ou eletrônico, para fins de estudo e pesquisa, desde que citada a fonte.

Catalogação na Publicação

Serviço de Biblioteca e Documentação

Faculdade de Educação da Universidade de São Paulo

Souza, Maria Paula Correia de

O discurso expositivo sobre biodiversidade e conservação em exposições de imersão

/Maria Paula Correia de Souza; orientação Martha Marandino São Paulo: 2017. 251p.

Tese (Doutorado - Programa de Pós-Graduação em Educação. Área de Concentração : Ensino de Ciências e Matemática) - Faculdade de Educação da Universidade de São Paulo)

1. Educação em museus 2.Sociologia da Educação 3. Educação Não Formal 4. Biodiversidade - Educação I. Marandino, Martha, orient. 


\section{FOLHA DE APROVAÇÃO}

Maria Paula Correia de Souza

O discurso expositivo sobre biodiversidade e conservação em exposições de imersão

Tese apresentada à Faculdade de Educação

da Universidade de São Paulo

para obtenção do título de doutora

Área de Concentração: Ensino de Ciências e Matemática

Aprovado em: / /

\section{Banca Examinadora}

Prof.(a) Dr.(a).

Instituição Julgamento

Assinatura

Prof.(a) Dr.(a).

Instituição Julgamento

Assinatura

Prof.(a) Dr.(a).

Instituição Julgamento

Assinatura

Prof.(a) Dr.(a).

Instituição Julgamento

Assinatura

Prof.(a) Dr.(a).

Instituição Julgamento

Assinatura 
Para André e Mariana.

Para que as futuras gerações

tenham sempre em mente: "A persuasão do poder está no silêncio que gera” (Bernstein). 


\section{AGRADECIMENTOS}

Encerro uma longa jornada, desafiadora em muitos momentos, realizadora em tantos outros. Grandes obstáculos se interpuseram neste final de ciclo, modificando minha percepção, muitas vezes pessimista, de qual é o nosso limite. Tenho certeza de que a amizade e o apoio possibilitaram estender os meus limites, em uma operação que nos transcende e nos torna vinculados ao outro. Não há palavras que possam traduzir exatamente meu agradecimento frente a esse nível de experiência. Assim, o que mais se aproxima textualmente do sentimento que quero exprimir é "obrigada". Palavra que como afirma o prof. António Nóvoa, carrega em si o estado mais profundo de agradecimento, aquele em que ficamos comprometidos com o outro.

À CAPES pelo financiamento desta pesquisa e do estágio no exterior.

À equipe da pós-graduação da Faculdade de Educação da Universidade de São Paulo, pelo profissionalismo e eficiência.

À professora Martha Marandino, companheira de muitas empreitadas, que muito além da orientação, compartilha comigo ideias, vontades, felicidades e por que não dizer, indignações. Obrigada pela motivação e carinho indispensáveis para chegar realizada ao final dessa etapa.

Ao professor Marcelo Motokane, por participar da minha vida profissional, trazendo um olhar entusiasmado sobre minhas pesquisas.

À professora Cláudia Galian, pela força que me motivou a realizar o estágio no exterior, pela contribuição inestimável no exame de qualificação, com ideias e sugestões.

À equipe da Fundação Zoo-botânica de Belo Horizonte, em especial à Ângela Lutterbach, Inês Andrade, Maria Guadalupe Fernandes, Humberto Mello e Miriam Pimentel, por me receberam com tanta gentileza e terem sido tão solícitos.

À Lilian Zaidan e Leopoldo Coutinho (em memória), pela solicitude e delicadeza. À Patrícia Ruggiero e à Aby Cohen pela atenção e pelas valiosas informações.

Às profas. Dras. Ana Maria Morais e Isabel Neves pela inspiração e contribuição no aprofundamento na compreensão da teoria e refinamento dos instrumentos de análise durante os meses do estágio em Portugal.

Aos amigos do GEENF (Grupo de Estudos em Educação Não Formal e Divulgação Científica), por todos os aprendizados, bons momentos de discussão e também de diversão.

Às companheiras do dia-a-dia, amigas e profissionais com as quais pude contar em todos os momentos desses quatro anos, Luciana Martins e Djana Contier. À Carolina Laurini, por sua amizade e dedicação. 
Às "Amigas-VIP" pelo incentivo constante, pela força inigualável. Ao amigo Gustavo por toda solicitude e carinho.

Aos meus pais, pelo apoio incondicional, mesmo em situações tão críticas, jamais imaginadas quando tudo isso começou. Obrigada por me motivar a ser crítica e acreditar que podemos contribuir para um mundo mais justo.

À minha irmã e amiga, por todo o apoio e motivação, muito além deste trabalho. Ao meu irmão, pela presença constante e pelo inequívoco humor.

Ao Jean, por toda ajuda e perseverança para o término do trabalho, pelo olhar atento e incentivo diário. Obrigada pelo amor e carinho, sobretudo pela compreensão e "extensão" dos meus limites. 


\section{RESUMO}

SOUZA, M. P. C. O discurso expositivo sobre biodiversidade e conservação em exposições de imersão

Frente ao importante papel educativo dos museus na atualidade, e considerando a ampliação do tratamento de temáticas ambientais nessas instituições, este trabalho busca compreender aspectos dos processos e práticas da educação museal relacionados à biodiversidade e à sua conservação em exposições de imersão. 0 presente trabalho se debruçou à análise sociológica do processo de produção dos discursos expositivos, com base na teoria de Basil Bernstein. Tal referencial teórico permite uma análise com forte potencial de descrição dos mecanismos internos e externos da constituição e funcionamento dos processos educacionais. Utilizamos também as discussões da área de educação em museus, além daquelas relacionadas às abordagens da biodiversidade em diferentes contextos educacionais. Com base nas perspectivas educacionais das exposições, esta pesquisa buscou identificar os campos recontextualizadores e os discursos oficiais dos museus, bem como caracterizar o processo de recontextualização específico à produção dos discursos expositivos. Foi também realizada a caracterização desses discursos buscando compreender quais são os significados legítimos sobre biodiversidade presentes nas mensagens de exposições de imersão, e quais são as formas legítimas da transmissão desses significados. Ainda, considerando que os discursos expositivos são resultado de processos de recontextualização, buscamos também relacionar as características deles com os processos que os geraram. A abordagem metodológica utilizada tem como base a pesquisa mista em educação, tendo como universo de análise duas exposições de imersão cuja temática tratada são biomas brasileiros. A análise dos campos recontextualizadores dos museus mostrou que há uma diversidade de agências que participam desses processos, bem como há diversas políticas públicas destinadas à educação em instituições museais. Essa diversidade está relacionada às diferentes tipologias de museus e suas afiliações. Ressaltamos a importância de diferentes agências de governo, do campo da economia e associações não-governamentais no fomento das ações de educação em museus. A análise dos processos de recontextualização dos discursos expositivos mostra que a regulação das agências às quais as instituições são vinculadas é fraca. A caracterização dos discursos expositivos mostrou que as exposições podem contribuir para o acesso a conhecimentos sobre biodiversidade relativamente complexos. Em particular, destacamos que as potencialidades das competências cognitivas são maiores que a complexidade dos conhecimentos. Esse fato está relacionado tanto às especificidades das exposições quanto à presença do objeto e o espaço, sendo de especial relevância a estrutura imersiva das exposições. É possível perceber que a expografia exerce papel importante para a ampliação das relações entre discursos de diferentes áreas (interdisciplinaridade), assim como a própria temática da biodiversidade. Quanto às relações entre humanos e natureza há predomínio de abordagens menos integradoras, chamando a atenção para que sejam adotados discursos mais atuais sobre a biodiversidade e conservação, que incluam, para além do seu significado na ciência, vieses sociais, políticos e culturais. Considerando a definição científica do termo, nota-se quanto às relações entre os componentes de composição, estrutura e funcionamento da biodiversidade, que os discursos apresentam um grau intermediário de relacionamento entre esses componentes, trabalhando especialmente os aspectos composicionais, que são justamente aqueles mais presentes nas concepções do público sobre biodiversidade. Finalmente, considerando o contexto não-formal de educação e a heterogeneidade dos níveis de conhecimentos dos visitantes, concluímos que as exposições têm importante potencial para o processo de aquisição de conhecimentos sobre biodiversidade. Os discursos expositivos, no que se refere ao nível de exigência dos conteúdos relacionados ao tema, podem contribuir para acessar conhecimentos relativamente complexos, que possibilitem obter informações confiáveis e outros pontos de vista para a reflexão sobre as questões ambientais.

Palavras-chave: Educação em museus; Sociologia da Educação; Educação Não Formal; Biodiversidade - Educação. 


\begin{abstract}
SOUZA, M. P. C. The expositive discourse related biodiversity and conservation in immersion exhibitions.
\end{abstract}

This work seeks to understand aspects of the processes and practices of museum education related to biodiversity and its conservation in immersion exhibitions. This understanding is necessary because of the important educational role of museums today, and considering the broader treatment of environmental themes in these institutions. A sociological analysis of the production process of expository discourses was carried out, based on Basil Bernstein 's theory. This theoretical reference allows an analysis with strong potential to describe the internal and external mechanisms of the constitution and functioning of educational processes. The discussions of the area of museum education were also used, in addition to those related to biodiversity approaches in different educational contexts. This research aimed to identify the recontextualizing fields and the official discourses of the museums, as well as to characterize the specific recontextualization process to the production of the expository discourses based on the educational perspectives of the exhibitions. The purpose of the characterization of these discourses was to understand what are the legitimate meanings about biodiversity present in the messages of immersion exhibitions, and what are the legitimate ways of transmitting those meanings. Still, considering that expository discourses are the result of recontextualization processes, we also try to relate their characteristics to the processes that generated them. The methodological approach used is based on mixed research in education, having as the universe of analysis two immersion expositions whose theme is Brazilian biomes. The analysis of the recontextualizing fields of the museums showed that there are a diversity of agencies that participate in these processes, as well as there are several public policies destined to the education in museums institutions. This diversity is related to the different typologies of museums and their affiliations. We emphasize the importance of different agencies of government, the field of economics and nongovernmental associations in the promotion of educational actions in museums. The analysis of the recontextualization processes of the expository discourses shows that the regulation of the agencies to which the institutions are linked is weak. The characterization of the expository discourses showed that the expositions can contribute to the access to knowledge on biodiversity relatively complex. In particular, we emphasize that the potentialities of cognitive skills are greater than the complexity of knowledge. This fact is related both to the specificities of the exposures as to the presence of the object and the space, being of special relevance the immersive structure of the expositions. It is possible to realize that the expography plays an important role for the expansion of the relations between discourses of different areas, as well as the biodiversity theme itself. Regarding the relationship between humans and nature, there is a predominance of less integrative approaches, drawing attention to the adoption of more current discourses on biodiversity and conservation, including, in addition to their meaning in science, social, political and cultural biases. Considering the scientific definition of the term, it is possible to notice the relations between the components of composition, structure and functioning of biodiversity, that the discourses present an intermediate degree of relationship between these components, working especially the compositional aspects, which are precisely those more present In public views on biodiversity. Finally, considering the non-formal context of education and the heterogeneity of visitor knowledge levels, we conclude that the exhibitions have important potential for the process of acquiring knowledge about biodiversity. The exposition speeches, regarding the level of demand of the contents related to the theme, can contribute to access relatively complex knowledge, that allow to obtain reliable information and other points of view for the reflection on the environmental questions.

Keywords: museum education; sociology of education; non formal education; biodiversity education. 


\section{LISTA DE ILUSTRAÇÕES}

Figura 1.1: Modelo do discurso pedagógico, adaptado de MORAIS e NEVES (2007b).58

Figura 1.2: 0 dispositivo e suas estruturas, adaptado de Bernstein (2000). 62

Figura 2.1: Exemplo de unidade de análise contendo objeto, texto e imagem................. 75

Figura 2.2: Aspectos do o "que" do discurso considerados para a análise......................... 75

Figura 2.3: Aspectos do "como" do discurso considerados para a análise.......................... 76

Figura 2.4: Componentes da biodiversidade, adaptado de Noss (1990) ........................... 82

Figura 3.1: Esquema das agencias e principais políticas do Campo de Recontextualização Oficial 99

Figura 3.2: Esquema dos principais programas relacionados à biodiversidade......... 108

Figura 3.3: Imagens de satélite da localização dos jardins ................................................ 123

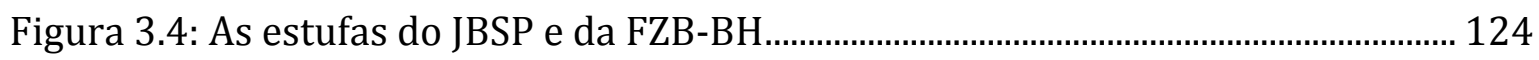

Figura 3.5: Representação da Casa de Adobe e material educativo para público em geral. 133

Figura 3.6: Objetos de artesanato e representação das feiras com produtos

medicinais; vista da representação dos ambientes naturais da Caatinga.

Figura 3.7: Vista geral da representação do ambiente natural de Cerrado e painel final da exposição.

Figura 3.8: Vista do aparato expositivo com vídeo e à frente no chão, janela de piso.

Detalhe da janela de piso. 139

Figura 3.9: Modelo do Discurso Pedagógico adaptado de Bernstein (1996). 148

Figura 4.1: Planta baixa da exposição "Estufa do Cerrado" com localização dos módulos.

Figura 4.2: Planta baixa da exposição "Estufa da Caatinga Mineira" com localização dos módulos. 163

Figura 4.3: "Estufa do Cerrado", unidade 22, módulo 4. 165

Figura 4.4: "Estufa do Cerrado", unidade 13, módulo 8. 165

Figura 4.5: "Estufa da Caatinga Mineira”, unidade 1, módulo 2. 166

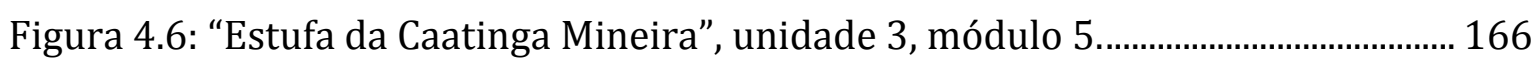

Figura 4.7 : Graus de complexidade dos conhecimentos................................................... 167

Figura 4.8: Graus de complexidade das competências. ....................................................... 168

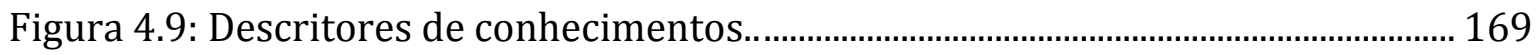

Figura 4.10: "Estufa do Cerrado", unidade 2, módulo 5 ..................................................... 170 
Figura 4.11: "Estufa da Caatinga Mineira", unidade 5, módulo 4.

Figura 4.12: Verbos de ação das competências.

Figura 4.13: "Estufa do Cerrado", unidade 6, módulo 4.

Figura 4.14: "Estufa do Cerrado", unidade 1, módulo 7.

Figura 4.15: "Estufa da Caatinga, unidade 2, módulo2. 175

Figura 4.16: "Estufa da Caatinga, unidade 2, módulo2. 175

Figura 4.17: Índice de complexidade dos conhecimentos e competências. 177

Figura 4.18: Diagramas de dispersão. 178

Figura 4.19: Diagramas mostrando as relações entre os módulos 180

Figura 4.20: "Estufa do Cerrado", unidade 5, módulo2. 181

Figura 4.21: "Estufa da Caatinga, unidade 1, módulo5. 182

Figura 4.22: Grau de relação entre os conhecimentos 182

Figura 4.23: "Estufa do Cerrado", unidade 11, módulo 4. 183

Figura 4.24: "Estufa da Caatinga Mineira", unidade 5, módulo 3. 184

Figura 4.25 : Grau de relação entre os componentes da biodiversidade. 185

Figura 4.26: Diagramas de Venn. 186

Figura 4.27: "Estufa do Cerrado", unidade 1, módulo 8. 187

Figura 4.28: "Estufa da Caatinga”, unidade 4, módulo5. 188

Figura 4.29: Grau de relação entre o ser humano e a natureza. 188

Figura 4.30: "Estufa do Cerrado", unidade 27, módulo 8. 189

Figura 4.31: "Estufa da Caatinga mineira”, unidade 2, módulo 4. 190

Figura 4.32: Índices totais de cada indicador. 191 


\section{LISTA DE QUADROS E TABELAS}

Quadro 1.1: Principais ideias de Bernstein ao longo da sua carreira, adaptado de Moore \& Maton (2001, p. 155).

Quadro 2.1: Contexto instrucional - 0 "que" do discurso. Complexidade dos conhecimentos científicos relacionados à biodiversidade. 78

Quadro 2.2: Contexto instrucional - 0 "que" do discurso. Complexidade das competências cognitivas relacionadas à biodiversidade 80

Quadro 2.3. Contexto instrucional - o "como" do discurso indicador. Relação entre saberes e/ou conhecimentos de diferentes áreas..

Quadro 2.4. Contexto instrucional - o “como" do discurso indicador - relação entre componentes da biodiversidade - intradisciplinaridade

Quadro 2.5. Contexto instrucional - o "como" do discurso indicador - relação entre natureza e humanos

Tabela 4.1: Características temáticas e expográficas da "Estufa do Cerrado" 160

Tabela 4.2: Características temáticas e expográficas da "Estufa do Caatinga Mineira" . 162 


\section{LISTA DE SIGLAS}

BGCI

Botanical Gardens Conservation International

CECA Committee for Education and Cultural Action (Comitê Internacional para Educação e Ação Cultural)

CAPES Coordenação de Aperfeiçoamento de Pessoal de Nível Superior

$\mathrm{CNPq}$ Conselho Nacional de Desenvolvimento Científico e Tecnológico

CDB Convenção da Diversidade Biológica

DEPDI Departamento de Difusão e Popularização da Ciência e Tecnologia

FAPs Fundações de Amparo à Pesquisa

FAPESP Fundação de Amparo à Pesquisa do Estado de São Paulo

FINEP Financiadora de estudos e projetos

FZB-BH Fundação Zoo-Botânica de Belo Horizonte

IBAMA Instituto Brasileiro de Meio Ambiente

IBRAM Instituto Brasileiro de Museus

ICMBio Instituto Chico Mendes de Conservação da Biodiversidade

ICOM International Council of Museums (Conselho Internacional de Museus)

INCTs Institutos Nacionais de Ciência e Tecnologia

INSA Instituto Nacional do Semiárido

JBRJ Jardim Botânico do Rio de Janeiro

JBSP Jardim Botânico de São Paulo

MCTIC Ministério da Ciência, Tecnologia, Inovação e Comunicações

MEC Ministério da Educação

MINC Ministério da Cultura

MMA Ministério do Meio Ambiente

OMCC Observatório de Museus e Centros Culturais

OS Organização Social

PELD Programa de Pesquisas Ecológicas de Longa Duração

PNEA Política Nacional de Educação Ambiental 


\begin{tabular}{|c|c|}
\hline PPBio & Programa de Pesquisa em Biodiversidade \\
\hline PNB & Política Nacional da Biodiversidade \\
\hline PNM & Política Nacional de Museus \\
\hline PNEM & Programa Nacional de Educação Museal \\
\hline \multirow[t]{2}{*}{ Probio } & Projeto de Conservação e Utilização Sustentável da Diversidade \\
\hline & Biológica Brasileira \\
\hline PRONABIO & Programa Nacional da Diversidade Biológica \\
\hline ProNEA & Programa Nacional de Educação Ambiental \\
\hline PRONAC & Programa Nacional de Apoio à Cultura \\
\hline $\mathrm{RBJB}$ & Rede Brasileira de Jardins Botânicos \\
\hline REM & Rede de Educadores de Museus \\
\hline SEA & Serviço de Educação Ambiental \\
\hline SECIS & Secretaria de Ciência, Tecnologia e Inclusão Social \\
\hline $\mathrm{SiBBr}$ & Sistema de Informação sobre a Biodiversidade Brasileira \\
\hline SISBIOTA & Sistema Nacional de Pesquisa em Biodiversidade \\
\hline SNJB & Sistema Nacional de Jardins Botânicos \\
\hline SNUC & Sistema Nacional e Unidades de Conservação \\
\hline UCs & Unidades de Conservação \\
\hline UNESCO & United Nations Educational, Scientific and Cultural Organization \\
\hline & (Organização das Nações Unidas para a Educação, Ciência e \\
\hline & Cultura) \\
\hline UEBT & Union for Ethical BioTrade \\
\hline
\end{tabular}




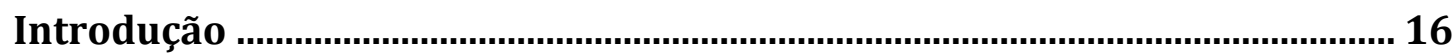

Contexto geral da pesquisa ............................................................................................. 16

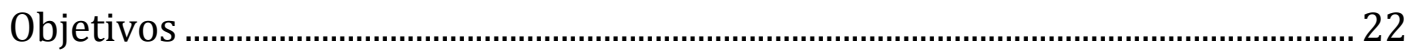

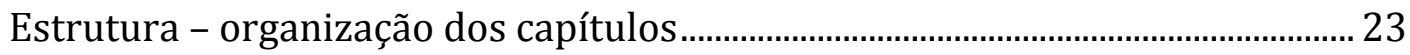

Capítulo 1 - Contextos teóricos da pesquisa: o olhar sociológico sobre as

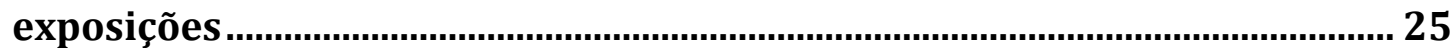

1.1 Teorias do currículo, transmissão cultural e as pesquisas em educação



1.2 A teoria de Basil Bernstein...................................................................................

1.3 O uso da teoria de Bernstein em diferentes contextos ..................................... 64

Capítulo 2 - Aspectos metodológicos: relações entre teoria e métodos....... 70

2.1 Aspectos gerais ..................................................................................................... 70

2.2 Instrumentos de coleta e análise dos dados......................................................... 72

Capítulo 3 - 0 processo de construção do discurso: agentes, agências e campos ................................................................................................................ 8 8

3.1 O Campo de Recontextualização Oficial dos museus.........................................89

3.2 O Campo Recontextualizador Pedagógico dos museus ..................................113

3.3 O processo de recontextualização dos discursos expositivos .....................119

Capítulo 4 - Análise do "que" e do "como" do discurso expositivo sobre biodiversidade em exposições de imersão ....................................................151

4.1 Análise dos resultados ......................................................................................159

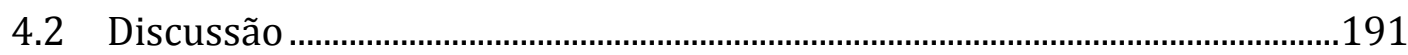

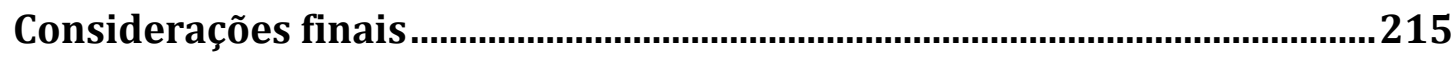

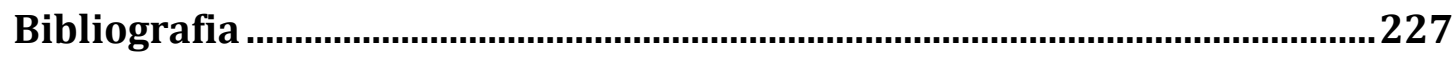

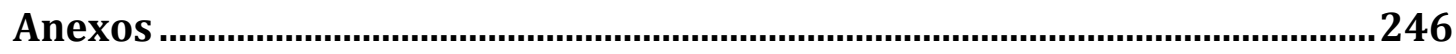

A Roteiro de observação da exposição ...............................................................246

B Roteiro de entrevista.....................................................................................248 


\section{Introdução}

\section{Contexto geral da pesquisa}

Em meio a uma possível "nova revolução tecnológica", denominada por alguns autores de "informacional" ou ainda de "terceira revolução industrial", notamos profundas mudanças e adaptações na economia, relações sociais, cultura, política e nas relações com o espaço. Conforme Sene (2008), esta situação impõe mudanças também no sistema educativo, quer no ensino formal, quer nas ações de educação não formal e no que se refere à educação ao longo da vida.

Apple (2006) traz importante reflexão sobre as mudanças que estão ocorrendo na sociedade e de suas implicações na educação, e discorre sobre qual o papel que esta última assume em uma sociedade em constante mudança: "De quem é o conhecimento de maior valor?". De acordo com Dussel (2009), a função da escola é a transmissão da cultura. Esta é também a função social de outras instituições que têm entre as suas missões a educação tais como os museus, parques e centros culturais. Neste contexto, precisamos refletir qual é a cultura a ser transmitida nesses diferentes espaços, o que dela é transmitido e, como e por que transmiti-la.

Vale apontar que outras instâncias de socialização têm tido papel fundamental na transmissão da cultura, tais como as mídias televisas, internet, aplicativos. As chamadas novas tecnologias adentram os espaços de educação com intuito de renovação e aproximação com os jovens que os frequentam. Essas novas instâncias de socialização convivem e inserem-se no cotidiano de instituições seculares, como os museus e escolas. Essas instâncias reinventam-se por meio das novas formas de transmissão da cultura, já que tais espaços eram outrora os únicos detentores da cultura legitima ${ }^{1}$.

A chamada "revolução tecnológica" contribuiu ainda mais para a crescente valorização do conhecimento científico e tecnológico, repercutindo no aumento da importância destes conhecimentos em sistemas educacionais de

\footnotetext{
${ }^{1}$ A ideia de cultura legítima ou dominante utilizada tem como origem a "Teoria da reprodução " de Bourdieu e Passeron, que tem como base a violência simbólica. Os autores destacam que há nas ações pedagógicas uma imposição de poder arbitrário. Uma vez que a arbitrariedade está relacionada na divisão da sociedade em classes, a classe dominante impõe a classe dominada sua própria cultura. Assim, a escola e
} 
vários países. Recomendações de diferentes instâncias propõem que os programas de educação formal e não formal sejam desenvolvidos e realizados para a formação de indivíduos críticos, aptos a questionar o conhecimento propagado pela mídia, que busquem seu próprio desenvolvimento cultural e científico de forma permanente e que valorizem a ciência como parte da cultura (SHAMOS, 1995).

Há uma diversidade de instituições que atuam na educação não formal, incluindo uma grande variedade de tipologias de museus. Desta forma, espaços como os jardins botânicos e parques naturais são considerados museus pelo órgão internacional $\mathrm{ICOM}^{2}$. Assim como os zoológicos, estas tipologias de museus têm a especificidade de apresentar elementos vivos na exposição, atraindo um número elevado de visitantes ${ }^{3}$. Além do aspecto educativo, está entre as missões dos jardins botânicos a conservação da biodiversidade, meta que permeia as diversas ações desenvolvidas nestes espaços.

Diversas estratégias de comunicação com o público têm sido adotadas pelos jardins botânicos, promovendo experiências, em que além dos conteúdos de botânica e conservação, são estimuladas as sensações e emoções dos visitantes. São exemplos destas estratégias os jardins sensoriais e trilhas interpretativas.

Atualmente, esse tipo de experiência tem sido trabalhada por meio das "exposições de imersão", as quais integram elementos vivos a outros objetos e aparatos. A intenção dessa concepção expositiva é propiciar aos visitantes uma imersão total nos ambientes, como se estivessem visitando o meio original, mesmo estando distante deles.

Marandino e Diaz (2011) ressaltam que, além da ideia de imersão no ambiente natural, nessas exposições são utilizadas técnicas museográficas que estimulam os cinco sentidos, associadas a informações científicas que podem ser apresentadas de forma interativa. Essa "forma" expositiva tem sido cada vez mais utilizada no sentido de permitir que a experiência da visita alie aspectos cognitivos, afetivos e sensoriais. Dadas as especificidades desse tipo de exposição,

\footnotetext{
2 International Council of Museums. A definição adotada pelo órgão está presente no estatuto de 2007, disponível em: http://icom.museum/the-vision/museum-definition/

3 De acordo com o relatório da OMCC (2006-2007), dentre as instituições consideradas museus pelo ICOM, os jardins zoológicos são aquelas mais visitadas pela população no Brasil, seguidas dos Jardins Botânicos.
} 
incluindo o menor número de trabalhos sobre elas, destacamos a importância de estudar os processos de sua produção e a efetividade dela junto ao público.

A ideia de integrar o visitante ao mundo que foi convidado a descobrir é relativamente recente. A exposição pode inserir o visitante na "cena", fazendo-o não apenas ocupar um espaço, mas também desempenhar um papel. De acordo com Davallon e colaboradores (1992) está presente na chamada museografia do meio ambiente ${ }^{4}$ a ideia do público inserido no "patrimônio-ambiente", que institui o sujeito visitante como ator social e que pode propiciar, como estratégia de visitação, condições para a reflexão sobre suas atitudes.

Durante o século XX os museus e centros culturais sofreram, de maneira geral, uma transformação em suas perspectivas de atuação. Tende-se atualmente à construção de discursos nos quais a ciência é evidenciada como um processo humano em construção, no qual cabem erros e versões controversas. Esta tendência possibilita a discussão e reflexão das implicações éticas, políticas, econômicas e ambientais do desenvolvimento científico e tecnológico que, ao impactarem a vida das sociedades, devem ser discutidas pelo conjunto dos cidadãos.

Para muitos autores os museus são locais privilegiados para esse tipo de abordagem, na medida em que podem trazer à tona, por meio de diversos tipos de ações de comunicação e educação, temas científicos atuais, contribuindo, dessa forma, para o maior diálogo entre a ciência e a sociedade (GONZÁLEZ et al., 2001; PEDRETTI, 2004; VILCHES et al., 2006). Assim sendo, a temática ambiental se converte em um objeto central e necessário para discussão nesses espaços.

A emergência das questões ambientais a partir da década de 70 teve grande influência sobre as exposições dos museus de ciências, introduzindo novas concepções e formas de abordagem sobre temas como biodiversidade e conservação, no sentido de repensar a relação do homem com a natureza, conciliando dois aspectos aparentemente antagônicos: desenvolvimento e conservação ambiental (PORCEDDA et al., 2006).

\footnotetext{
4 Perante a uma vertente "verde" esboça-se um novo papel para o museu: o de ser um "espaço público" que oferece a possibilidade de se formar opinião sobre o que está em vias de tornar-se o "patrimônio verde". 0 encontro da relação do Homem com a natureza pelo Museu se dá, principalmente, na ampliação da noção de patrimônio pelo parque natural, e, depois, pelo ecomuseu (DAVALLON, GRANDMONT, SCHIELE, DE KONINCK, 1992).
} 
Tema bastante presente na sociedade, a biodiversidade assume diferentes contornos e pode apresentar definições diversas, relacionadas ao contexto de sua utilização, refletindo em maior ou menor grau os princípios dominantes sobre o tema na sociedade. As pesquisas de opinião realizadas pelo ministério do Meio Ambiente de 1992 a 2012 mostram que a conscientização dos brasileiros sobre o ambiente natural e a biodiversidade, além da sua importância para a vida e atividades humanas, aumentou ao longo dos últimos 20 anos. De acordo com essas pesquisas, a capacidade de reconhecer elementos da biodiversidade também se modificou nesse período, abrangendo conceitos mais sofisticados sobre o que compõe o meio ambiente e a biodiversidade (BRASIL, 2012). Para além dos conceitos, fatos e fenômenos científicos, o termo biodiversidade pode incluir aspectos relacionados à valorização da natureza pelos seres humanos, além de atitudes acerca da importância e necessidade de conservá-la.

Por conta das possibilidades educacionais da apresentação de temas ambientais em exposições imersivas e do pequeno número de estudos realizados nesses contextos, selecionamos duas exposições de imersão para análise empreendida nesta investigação. Além dessas similaridades, ambas exposições estão sediadas em jardins botânicos; a "Estufa do Cerrado" está presente no Jardim Botânico de São Paulo e a "Estufa da Caatinga Mineira" faz parte do Jardim Botânico da Fundação Zoo-botânica de Belo Horizonte - Minas Gerais.

Uma perspectiva de análise sobre como as questões ambientais vem sendo tratadas em contextos museais deve levar em consideração a função social destas instituições ${ }^{5}$, bem como os contextos históricos e atuais da concepção das suas ações, dentre elas as exposições. As diversas ações desenvolvidas pelos museus e outras instituições que atuam no campo da educação não formal podem ser analisadas a partir da premissa de que elas são discursos e que possuem uma mensagem. Estes discursos são construídos com o envolvimento de diferentes atores sociais que possuem uma variada bagagem de conhecimento e que estão imersos em um contexto sociocultural, político e econômico.

\footnotetext{
${ }^{5}$ Partimos do pressuposto de que os museus para além da função de salvaguarda do patrimônio material e imaterial, tem como fim propiciar à sociedade a compreensão da realidade presente por meio da valorização e entendimento da memória preservada, "colaborando para que o cidadão possa se apropriar e preservar o seu patrimônio, pois ele deverá ser a base para toda a transformação que virá no processo de construção e reconstrução da sociedade" (SANTOS, 1993, p. 99)”. Resumidamente, concordamos com Bruno (1998) que a função social e educativa dos museus é proporcionar a compreensão sobre patrimônio (seja material ou imaterial) e o exercício da cidadania.
} 
De acordo com Marandino (2001) e Martins (2011), os discursos presentes nos museus estão inseridos em uma complexa rede de relações estabelecidas entre a instituição e o público, numa lógica em que estes discursos são a voz e a mensagem da instituição. Levando em consideração a importância dos museus como espaços privilegiados para a educação, expressa no processo comunicativo entre a instituição e os visitantes (HOOPER-GREENHILL, 1994a), faz-se necessário estudar a construção dos discursos presentes nas ações educativas, no sentido compreender o "que" está sendo comunicado, o "por quê" que está sendo comunicado e o "como" está sendo comunicado.

O discurso expositivo, enquanto prática institucional, é um campo de estudos bastante abrangente, pois os museus são instituições diversificadas, tanto no que se refere a sua tipologia de acervo, quanto à sua história, contexto sociocultural, perfil institucional e tipo de público frequentador.

A compreensão do discurso expositivo pode ser realizada entendendo-o como um discurso pedagógico ${ }^{6}$, de acordo com a teoria proposta por Basil Bernstein. Esse autor construiu um amplo escopo teórico na área da sociologia, com fortes ligações com outras áreas do conhecimento, em particular com a educação. Sua teoria pode ser incluída na análise crítica do currículo. As ideias e conceitos propostos por Bernstein são passíveis de utilização em diferentes contextos de análise, fornecendo modelos para descrever e analisar as relações sociais que constituem as práticas de organização, as práticas discursivas e de transmissão inerentes a qualquer tipo de ação pedagógica (BERNSTEIN, 1990, 1996).

O conceito de dispositivo pedagógico foi concebido pelo autor para analisar diversos aspectos envolvidos na produção e transmissão do discurso pedagógico. De acordo com Mainardes e Stremel (2010), o discurso pedagógico, tal como concebido por Bernstein, é também um princípio, que regula os processos de recontextualização. Nestes processos ocorre uma descontextualização de um discurso de sua prática e contexto originais, e recolocação dele com base em princípios de focalização e reordenamentos seletivos de um novo contexto. Com isso, é possível dizer que há a produção de um

\footnotetext{
${ }^{6}$ Marandino (2015, p. 177) propõe que o discurso expositivo "se comporta de forma semelhante ao pedagógico, pois desloca outros discursos a partir de seus princípios e objetivos, assumindo as características do discurso recontextualizador".
} 
novo discurso, pois as ideias originalmente propostas são inseridas em outros contextos que permitem e demandam releituras, reinterpretações e mudanças nos significados iniciais.

Dada as possibilidades de análise dos processos de produção e reprodução do discurso pedagógico em diferentes contextos, ressaltamos a aplicabilidade do conceito do dispositivo pedagógico em outros ambientes para além da educação formal. A aplicação das ideias e conceitos da teoria de Bernstein está presente nos estudos realizados por Marandino (2001), Botelho (2001) e Martins (2011) no âmbito da educação em museus.

De acordo com Mortensen (2010), a análise do discurso expositivo tem o potencial de ajudar tanto os educadores das instituições e pesquisadores da área de educação em museus, bem como as pessoas que concebem as exposições, a entender o processo de ensino e de aprendizagem que ocorre durante uma visita e estabelecer critérios relevantes para avaliar a qualidade para melhor produzir exposições em museus.

Além disso, conforme Achiam e Marandino (2014), os museus apresentam possibilidades únicas no engajamento do público em questões científicas. 0 conteúdo científico em museus e exposições, assim como em outros espaços de educação, tem grande influência do processo de construção da ciência em que estes conteúdos foram produzidos. Assim, "os esforços para entender exposições devem, portanto, incluir esforços para compreender a produção de exposições" (ACHIAM e MARANDINO, op. cit., p. 67).

Notadamente o conceito de dispositivo pedagógico permite analisar como se relacionam o poder e controle que diferentes sujeitos, discursos e instituições possuem nos processos de produção das mensagens e códigos, ou seja, na produção de conhecimentos e transmissão da cultura. É pertinente então questionar quais são os agentes e agências que participam dos processos de recontextualização e como se dá essa participação nos diversos níveis da produção dos discursos presentes nos museus.

Com base nas perspectivas educacionais das exposições, esta pesquisa busca conhecer como se dá a produção dos discursos expositivos em contextos museográficos imersivos, não apenas com relação aos conceitos científicos de forma isolada, mas principalmente no que diz respeito a temas muito presentes na 
atualidade e que demandam a participação efetiva para a tomada de decisão, como é o caso da biodiversidade. A partir dessas premissas, consideramos importante questionar quais são os significados legítimos sobre biodiversidade presentes nos discursos de exposições de imersão, e quais são as formas legítimas da transmissão desses significados. Por fim, levando em conta que os discursos expositivos são resultado de processos de recontextualização, cabe indagar como as características dos discursos expositivos se relacionam com os processos de recontextualização que os geraram.

A partir do que foi exposto, levantamos questionamentos que se traduziram nos objetivos desta investigação. Apresentamos a seguir tais objetivos, em que se consideram a problemática apresentada de acordo com a realidade empírica e o referencial teórico adotado.

\section{Objetivos}

\section{Objetivos gerais}

- Compreender a construção do discurso expositivo em duas exposições de imersão, com foco nos temas da biodiversidade e conservação, revelando as relações de poder presentes no processo de transmissão cultural em museus.

- Colaborar no estabelecimento de referenciais de análise de exposições a partir do estudo sociológico dos discursos expositivos.

\section{Objetivos específicos}

- Identificar os campos recontextualizadores relacionados à educação em museus e aqueles que influenciam no processo de construção dos discursos expositivos de duas exposições de imersão em jardins botânicos.

- Caracterizar os agentes e discursos que compõem o campo recontextualizador pedagógico das exposições analisadas.

- Analisar as características dos discursos expositivos sobre biodiversidade e conservação quanto aos componentes instrucionais, o "que" do processo de transmissão-aquisição (conceitos e competências).

- Analisar as características dos discursos expositivos quanto às relações entre discursos, ou seja, o "como" do processo de transmissão-aquisição (relações 
entre e dentro das áreas de conhecimento, entre os módulos expositivos e entre os seres humanos e a natureza).

- Discutir como as características dos discursos expositivos se relacionam às ideologias e objetivos dos conceptores da exposição e das agências envolvidas, buscando compreender as escolhas, seleções, restrições e refocalizações a partir do processo de recontextualização.

- Contribuir no desenvolvimento de critérios relevantes que avaliem as ações educativas e permitam aperfeiçoar a produção de exposições em museus.

\section{Estrutura - organização dos capítulos}

Apresentamos a seguir a estrutura da tese. No primeiro capítulo são apresentados os aspectos gerais da teoria de Basil Bernstein. 0 contexto teórico tem como base a revisão da bibliografia produzida pelo autor e de outros trabalhos de síntese e discussão das suas obras. 0 objetivo é dar um panorama geral dos conceitos e modelos propostos por Basil Bernstein, enfatizando o modelo do discurso pedagógico que será utilizado nesta investigação. Dentro da perspectiva teórica trazemos ainda um pequeno levantamento de pesquisas que utilizam diferentes aspectos da teoria proposta por Basil Bernstein.

No que se refere ao contexto metodológico, são apresentados no capítulo dois, as características que configuram a metodologia utilizada neste trabalho como pesquisa mista, bem como, os principais aspectos da coleta de dados, instrumentos de análise e de tratamento dos resultados.

De acordo com o modelo do discurso pedagógico, a concepção das exposições remete-se à dimensão da produção do discurso. No terceiro capítulo empreendemos a análise do processo de concepção das exposições "Estufa do Cerrado" presente no Jardim Botânico de São Paulo e "Estufa da Caatinga Mineira" sediada na Fundação Zoo-botânica de Belo Horizonte. Nesse capítulo efetuamos a descrição dos agentes envolvidos, do ponto de vista de seus objetivos e intenções, além da identificação das instituições partícipes na produção do discurso expositivo. A partir dessa análise, buscamos discutir como 
o poder e controle posicionam e opõem os agentes e agências no processo de produção do discurso expositivo.

No quarto capítulo são analisados o "que" e o "como" dos discursos expositivos relacionados à temática da biodiversidade. Para isso foram utilizados conceitos do modelo do discurso pedagógico de Bernstein, além da ideia e metodologia associada ao nível de exigência conceitual proposto pelo grupo de Estudos Sociológicos de Sala de Aula (ESSA). No primeiro item desse capítulo, o foco está na análise da complexidade dos conhecimentos científicos e competências cognitivas sobre biodiversidade, trazendo a discussão sobre as possibilidades educacionais da visita às exposições. Além disso, procuramos identificar as proximidades e distâncias entre os objetivos e intenções dos conceptores das exposições e os resultados obtidos na análise.

No segundo item do capítulo 3, analisamos o "como" do discurso expositivo sobre biodiversidade, isto é, as relações estabelecidas entre os discursos. Especificamente ao "como" analisamos as relações entre saberes e/ou áreas de conhecimento, as relações entre os componentes da biodiversidade e ainda, as relações entre seres humanos e natureza. A análise foi realizada com base no conceito de classificação proposto por Bernstein. Na discussão refletimos como o grau de relação entre os discursos contribuem para a complexidade dos conteúdos de biodiversidade apresentados nas exposições. Bem como, buscamos relacionar as características dos processos de recontextualização que produziram os discursos expositivos com a forma de realização das mensagens expressas pelas exposições.

O item final do capítulo 3 reúne os aspectos do "que" e do "como" dos discursos, discutindo como eles contribuem para a complexidade dos conteúdos sobre biodiversidade nas exposições.

Nas considerações finais buscamos responder as questões norteadoras da tese, integrando os resultados e discussões presentes nos capítulos. 


\section{Capítulo 1 - Contextos teóricos da pesquisa: o olhar sociológico sobre as exposições}

\subsection{Teorias do currículo, transmissão cultural e as pesquisas em educação em museus}

As teorias de currículo tem há algum tempo ocupado espaço importante entre aqueles que se preocupam em compreender e estudar o universo da Educação Formal. Segundo Silva (2002), inicialmente a perspectiva dos estudos curriculares estava associada com o "como" ensinar, ou seja, tinham como enfoque a prescrição dos melhores métodos para o ensino.

Como aponta o autor, as teorias críticas que ganharam força, nos Estados Unidos e Europa, a partir da década de 1960, procuram trazer outras dimensões aos estudos de currículo associadas ao "por quê" se ensina determinados conteúdos utilizando-se de determinadas metodologias. As teorias críticas trazem também para o cerne das discussões sobre o currículo questões ideológicas, relacionadas ao papel do processo de escolarização na manutenção das classes sociais, na reprodução dos discursos das classes dominantes e na legitimação do viés cultural dominante. As discussões levantadas pelos estudos curriculares sob esse novo enfoque, não ficaram restritas apenas a educação escolar, motivando discussões em outros campos (GOODSON, 1995).

Assim, pode-se esperar que as discussões acerca dos programas e currículos tenham tido também reflexos em espaços como museus, universo desta pesquisa de doutorado. Os museus apresentaram ao longo de sua história uma progressiva ampliação do enfoque educacional e, atualmente, pode-se considerar que a educação está entre os seus principais papeis sociais. De acordo com Hooper-Greenhill (1994a), a função mais importante de uma instituição museológica é a de educação de seus públicos e é essa função que justifica, do ponto de vista social e econômico, a manutenção dos museus no mundo contemporâneo. Ao corroborar com essa afirmação, este trabalho parte do pressuposto de que a educação e comunicação museal deve ser vista como um dos orientadores das ações de um museu. Nessa direção, é possível compreender os museus como instituições fundamentais não só para a estruturação da 
pesquisa em diversas áreas do conhecimento (BRANDÃO, 1999; LOPES, 1997; SCHWARCZ, 1989) mas, principalmente, para a divulgação do conhecimento científico para uma diversidade de públicos "não especialistas" (CAZELLI, 1992, 2000; ASENSIO, 1999; CAZELLI et al., 2003; MARTINS, 2000; FALK e STORKSDIECK, 2005).

De acordo com Bourdieu (1998), a educação em museus possui especificidades tanto no que se refere às práticas pedagógicas, quanto ao próprio processo de produção de conhecimento. Muitas dessas instituições, como os museus de história natural, tiveram sua origem ligada às universidades $\mathrm{e}$ apresentavam como principais funções a de abrigar coleções botânicas e zoológicas e a de propiciar a formação de especialistas (STUDART et al., 2003). Além dos aspectos ligados a constituição histórica dessas instituições e de sua importância educacional, elas possuem outras especificidades importantes que as abrigam sob a nomenclatura "museu", como o caráter preservacionista de suas ações e a capacidade de ressignificação, colocando-as, ainda hoje, como instituições ligadas à produção de conhecimento e detentora da cultura legítima.

Vale ressaltar que apesar dessas instituições apresentarem um conjunto de aspectos que permitem considerá-las museus, elas podem ter características bastante diversas, que influenciam no papel social e educativo que desempenham. Entre essas características podemos apontar os elementos relacionados à constituição histórica e tipologia de acervo que abrigam. E também, aspectos pertinentes ao contexto sociocultural na qual estão inseridas, à constituição de suas equipes, ao perfil de seus visitantes e potenciais públicos almejados. Para ilustrar a diversidade de tipologias, podemos citar os zoológicos e jardins botânicos, que apresentam constituição histórica e acervos vivos bastante distintos dos museus de arte, e no entanto, estão abrigados sob essa mesma definiçãa ${ }^{7}$. Por outro lado, essas instituições apresentam semelhanças,

\footnotetext{
${ }^{7}$ Segundo o ICOM (International Council of Museums) são considerados museus sítios e monumentos naturais, arqueológicos e etnográficos; instituições que adquirem, conservam e difundem a prova material dos povos e de seu entorno; jardins zoológicos, botânicos, aquários e viveiros; centros de ciência e planetários; galerias de exposição não comerciais; parques naturais; organizações internacionais, nacionais, regionais e locais de museus; ministérios ou as administrações sem fins lucrativos, que realizem atividades de pesquisa, educação, formação, documentação e de outro tipo, relacionadas aos museus e à museologia; centros culturais e demais entidades que facilitem a conservação e a continuação e gestão de bens patrimoniais, materiais ou imateriais; qualquer outra instituição que reúna algumas ou todas as características do museu, ou que ofereça aos museus e aos profissionais de museus os meios para realizar pesquisas nos campos da Museologia, da Educação ou da Formação.
} 
por ter entre suas missões a funções sociais e educativas "a compreensão sobre patrimônio, herança e o exercício da cidadania" (BRUNO, 1998, p.27).

Diante dos aspectos mencionados acerca das instituições museais e que precisam ser considerados para uma análise de seu papel educativo, coloca-se a necessidade de definir e compreender as especificidades da educação em museus e como se caracteriza a prática educativa desenvolvida nesses espaços, ou seja, é necessário delimitar a pedagogia museal. A recente constituição da área de educação em museus tem trazido para o debate a compreensão de como esta dimensão foi se estruturando enquanto prática e teoria dentro dos museus (ALLARD e BOUCHER, 1991; ALLARD e LEFEBVRE, 1995), quais são linhas pedagógicas que influenciaram as práticas educacionais museais (HOOPERGREENHILL, 1994a; HEIN, 1996; HEIN e ALEXANDER, 1998; SOUZA, 2009), as diversas mudanças conceituais nos rumos das exposições em busca de uma comunicação efetiva com os diversos públicos (KAPLAN, 1995; STUDART et al., 2003) e a aprendizagem possível nesses espaços (BORUN, 1983; FALK, 2001; BIZERRA, 2007).

Entretanto, muitos desafios ainda persistem em busca de uma epistemologia da educação em museus. Uma dessas questões tem relação com a definição do próprio âmbito educacional, ou seja, o campo de inserção da educação em museus. Encontra-se na literatura algumas possibilidades como educação não formal, educação informal e aprendizado por livre-escolha (FALK, 2001). De acordo com Smith (2001), o termo "não formal" aparece em discursos internacionais e politicas educacionais a partir do final da década de 1960, relacionado muitas vezes à projetos e programas de cunho educativo para grupos em situação de desvantagem social. Esse autor aponta ainda, que este termo passa a ser mais comum a partir do inicio da década de 1970, quando, frente às novas demandas sociais, é declarada pela UNESCO a necessidade de uma educação a longo prazo, a chamada "educação ao longo da vida" (UNESCO, 1972 apud SMITH, 2001). De acordo com Gohn (2006), a análise da literatura acerca das definições da educação não formal e/ou informal mostra uma tendência a fazê-las em oposição as características da educação formal.

Discussões acerca da inserção da educação em museus no âmbito da educação não formal tem sugerido algumas especificidades comuns às práticas 
educativas realizadas nesses espaços, como as questões relativas a temporalidade, sequência e ritmo das atividades e também, acerca dos programas e currículos (MARANDINO et al., 2004). Alguns autores têm trabalhado no sentido de delimitar a educação não formal segundo seus programas e currículos, como o caso de Jeffs e Smith (1990) que propõem uma distinção entre o campo formal e não formal, de acordo com o planejamento curricular. Assim, os currículos formais seriam aqueles concebidos sem a participação daqueles para os quais os programas se destinam. Já na educação não formal, esses currículos seriam negociados pelos diferentes indivíduos que participam dos processos educacionais nesse campo.

Ainda que se caminhe para a construção de uma pedagogia própria dos contextos museais, as tendências pedagógicas que aparecem originalmente para um contexto formal podem ser utilizadas como ferramentas de análise sobre o papel educativo de museus. Pesquisas sobre aprendizagem em museus de todas as tipologias vêm sendo feitas ha décadas com base em autores amplamente usados na análise desse processo na escola. No que concerne os museus de ciências, especialmente na análise de exposições ou ações educativas, pesquisas têm utilizado para análise modelos e tendências pedagógicas referentes à educação formal, a formação de professores mas também a discussões sobre as relações entre ciência, tecnologia, sociedade e ambiente (CTS\&A). Da mesma maneira, as teorias de currículo, que muitas vezes parecem estar voltadas apenas à educação formal, trazem reflexões muito mais amplas, que dizem respeito às formas como a sociedade se relaciona com o conhecimento e legitima a produção, seleção e apropriação da cultura.

No sentido de compreender as especificidades educacionais dos museus, Hooper-Greenhill (1994b), aponta as principais influências teóricas advindas do campo da educação que têm marcado o mundo dos museus. De acordo com a autora, não há consenso acerca de qual a melhor abordagem educativa a ser empregada nos espaços museais, mas de forma geral é possível distinguir duas correntes principais. Uma delas tem caráter positivista, compreende $\mathrm{o}$ conhecimento como exterior ao aprendiz. A outra tem caráter construtivista, e o conhecimento é considerado algo a ser dialogado na interação do público com o 
ambiente social. Nessa perspectiva há maior espaço para a subjetividade como parte dessa construção.

Assim, de acordo com Hooper-Greenhill (op. cit.), há duas abordagens de comunicação/educação que podem ser transpostas para o contexto museal: abordagem transmissora e abordagem cultural. A autora afirma ser a primeira abordagem a mais comum nos museus em que não há um processo de reflexão sobre as práticas desenvolvidas pela instituição, bem como, não se estabelece um diálogo efetivo com o público. Já na abordagem cultural a sociedade é considerada parte do processo de comunicação como um todo, atuando na produção, manutenção e transformação deste.

Dessa forma, ao ser aplicado nos museus, o modelo transmissor implica em um tipo de comunicação linear, em que pesquisa de público, consulta de audiência e avaliação não fazem parte do processo. A abordagem cultural, por sua vez, baseada no paradigma construtivista de aprendizado, é a mais presente hoje nos Estudos Culturais e tem despertado grande interesse dentro da comunidade museológica. Nessa perspectiva comunicacional, a realidade é moldada em um processo de negociação contínua entre as experiências, crenças e valores prévios do indivíduo que, dentro da estrutura das comunidades, constrói seus próprios sentidos e significados. Na aplicação dessa abordagem nos museus, a autora afirma a correlação possível entre a prática museal e o público, para além da mera contemplação passiva.

Hooper-Greenhill (1994b), propõem que o público vê o museu a partir de sua própria perspectiva, escolhendo o que visitar e examinando o significado da visita através do seu olhar pessoal. Assim, a autora enfatiza a importância da perspectiva histórica e da inserção social dos sujeitos na construção do conhecimento e afirma que a audiência dos museus é ativa e portanto, a comunicação possível nesses espaços deve partir dessa premissa. Essa é a base que determina a pedagogia crítica, defendida pela autora como a teoria mais adequada para a prática pedagógica em museus.

Nota-se que o estabelecimento de uma pedagogia museal vem se desenvolvendo nos campos de estudo mais voltados aos processos de ensinoaprendizagem, havendo também alguns autores que têm buscado compreender a 
educação museal por meio do uso das teorias curriculares. No entanto, conforme aponta Martins (2011), essa perspectiva de análise é incipiente, havendo um número restrito de autores e estudos que utilizam as teorias de currículo para a compreensão da educação em museus.

Os estudos analisados por Martins (op. cit.) revelam uma aproximação entre os processos educativos dos museus e as teorias tradicionais de currículo. Isso porque tais trabalhos se propõem a analisar o que, por que e como os museus ensinam, com o objetivo de definir um modelo curricular mais adequado. A autora destaca dois principais eixos de investigação da área curricular em museus. Um deles busca propor um currículo museal, no sentido de compreender e melhor divulgar as práticas e processos internos dos museus, em uma percepção de que esses espaços são "locais curriculares", e na mesma lógica dos currículos da educação formal, devem contribuir para a melhoria da educação pública. Outros trabalhos, além de descrever os elementos que fazem parte da educação museal, têm como foco evidenciar a especificidade da aprendizagem em museus, escabelando um modelo curricular que abarque as melhores qualidades dessa aprendizagem.

Nesse sentido, é possível perceber que as análises curriculares da educação em museus trazem semelhanças com as perspectivas de investigação dos autores que analisam por exemplo, as linhas pedagógicas da educação museal, a aprendizagem nesses espaços e/ou a comunicação com os diversos públicos. De acordo com Martins (op. cit.), elementos relacionados às especificidades da educação em museus como objetos, tempo, espaço e comportamento do público, assim como, preocupações relacionadas ao aperfeiçoamento da prática pedagógica museal, são elementos trazidos tanto entre os trabalhos que utilizam as teorias curriculares quanto entre os autores da área de educação em museus.

No entanto, como ressalta a autora, os trabalhos que utilizam uma perspectiva curricular para a compreensão da educação em museus, não analisam em profundidade como se dão os processos de seleção e realocação de determinados temas, conteúdos e ações, assim como, não aprofundam a compreensão das relações de poder que se estabelecem dentro dos contextos 
museais e desses com outras áreas do conhecimento, em uma perspectiva mais crítica ou pós-crítica das teorias de currículo.

De maneira geral, as teorias críticas do currículo estão focadas nas questões de poder envolvidas na determinação dos currículos escolares: quem seleciona o currículo e porque seleciona? O que é selecionado e com que interesses? Quais as contingências políticas, econômicas, sociais e culturais que determinam essa seleção? Mais do que saber como ensinar os diversos conteúdos, questionamento central presente das teorias tradicionais, as teorias críticas "estão preocupadas com as conexões entre saber, identidade e poder" (SILVA, 2002, p.17).

Dentre a teoria crítica do currículo destacamos o movimento de reconceptulização do campo do currículo, ocorrido nos EUA a partir da década de 1960, constituindo duas linhas principais: a fenomenologia e o materialismo histórico. Os principais nomes desse movimento são: William Pinar, Michel Apple, Henry Giroux, entre outros. Apesar das muitas distinções existentes dentro da Sociologia do Currículo ${ }^{8}$, a preocupação geral estava voltada à identificação e eliminação "de aspectos que contribuíam para restringir a liberdade dos indivíduos e dos diversos grupos sociais" (PINAR e GRUMET, 1981 apud MOREIRA e SILVA, 1995, p. 15).

Outra vertente da teoria crítica do currículo foi a Nova Sociologia da Educação (NSE), originária da Inglaterra, e que tem entre seus principais pesquisadores, Michel Young, Basil Bernstein, Nell Keddie, Pierre Bourdieu e Geoffrey Esland, entre outros. De acordo com Moreira e Silva (1995, p. 20) a Sociologia da Educação estava voltada à compreensão dos "processos de seleção, distribuição, organização e ensino dos conteúdos curriculares e a estrutura de poder do contexto social inclusivo". O currículo é, para a NSE, uma construção social, histórica e economicamente determinada, sendo papel dos estudiosos desvelar os mecanismos por trás dessa construção.

\footnotetext{
${ }^{8}$ As duas correntes são a neomarxista e da teoria crítica, representadas mais comumente por Michel Apple e Henry Giroux, e uma segunda corrente mais associada à hermenêutica e às tradições humanistas, cujo principal representante é William Pinar. A respeito das diferenças entre as duas linhas, Moreira e Silva (1995, p.15) afirmam que "para os neomarxistas, os humanistas secundarizavam a base social e o caráter contingencial da experiência individual. Estes últimos, por sua vez, acusavam os primeiros de subordinar a experiência humana à estrutura de classes, dela eliminando a especificidade, a inventividade, bem como a capacidade de resistência e de transcendência".
} 
De acordo ainda com Moreira e Silva (op. cit.), os temas centrais da análise crítica e da sociologia do currículo podem ser resumidos em alguns grandes eixos. 0 primeiro deles é voltado às análises da conexão entre currículo e ideologia. Baseada nas proposições de Althusser acerca dos Aparelhos Ideológicos do Estado, essa perspectiva tem como proposta compreender os mecanismos ideológicos atuantes na educação e, mais precisamente, na escola, findando com o ideário de uma escola e uma educação apolíticas e isentas.

A partir do conceito de ideologia, o próprio conceito de conhecimento passa a ser revisto. Dentro dessa perspectiva, a linguagem, veículo pelo qual o conhecimento se expressa, é vista como produtora de realidade, constituída ideologicamente, e não mais como uma mera ferramenta isenta e inquestionável. As implicações dessa abordagem para os estudos das relações entre currículo e conhecimento são muitas, já que a questão não é mais "saber qual conhecimento é verdadeiro, mas qual conhecimento é considerado verdadeiro" (SILVA, 2002, p. 46, grifo do autor), e por quem ele é assim considerado.

Conforme Moreira e Silva (1995), um segundo eixo de investigações da análise crítica e da sociologia do currículo são as relações entre currículo e cultura. A grande modificação das teorias críticas em relação às tradicionais nesse quesito passa, justamente, pelo questionamento do próprio conceito de cultura. Enquanto nas teorias tradicionais existe uma herança cultural da humanidade, estática e atemporal, que deve ser passada aos aprendizes, nas teorias críticas essa herança é questionada, tanto no que se refere à sua transmissão, quanto ao seu conteúdo.

$\mathrm{Na}$ concepção crítica não existe uma cultura da sociedade, unitária, homogênea e universalmente aceita e praticada e, por isso, digna de ser transmitida às futuras gerações através do currículo. Em vez disso, a cultura é vista menos como uma coisa e mais como um campo e terreno de luta. Nessa visão, a cultura é o terreno em que se enfrentam diferentes e conflitantes concepções de vida social, é aquilo pelo qual se luta e não aquilo que recebemos. (MOREIRA e SILVA, op. cit., p. 27). Como aponta Young (2011), o acesso ao conhecimento pode ser transformador, mas isso não está nas mãos apenas do currículo ou da escola, uma vez que a sociedade é desigual. 0 autor defende que o 
currículo e a escola poderiam levar o aluno a superar a condição da experiência, empoderando-se do instrumental mais abrangente, que para além da formação de sua própria identidade, permite influenciar nas transformações e no empoderamento da própria comunidade na qual está inserido.

Os estudos de currículo que trazem discussões sobre a educação e a cultura como os de Forquin (1993), podem ser bastante importantes para a compreensão do papel educativo dos museus. Em primeira instância, pela função social que essas instituições assumiram ao longo da história como locais de salvaguarda do patrimônio e acesso à cultura. Por outro lado, coloca-se o papel comunicativo e educacional dessas instituições junto ao seu público. Assim, os museus poderiam ser considerados os locais que abrigam objetos e o legado cultural humano, e que possibilitam a (re)significação disso para seus visitantes.

Podemos notar que as exposições mudaram suas formas de comunicação com público, passando a ser concebidas a partir de objetivos que levam em consideração o que, como e para quem se quer comunicar. 0 acervo não é totalmente exposto, havendo aqui também uma seleção de acordo com os significados culturais, sociais, econômicos, religiosos dos objetos e que seguem também os objetivos e o olhar das equipes que concebem as exposições.

Corroborando com a proposta de delimitação do campo da educação não formal proposta por Jeffs e Smith (2001), em que os currículos possuem uma maior negociação entre os envolvidos, nota-se uma ampliação da participação do público na concepção, reestruturação ou adaptação das exposições. Assim é possível encontrar instituições, que desde a formação das equipes para planejar a construção do espaço físico que ela ocuparia, contou com a participação de diversos atores sociais, com forte tendência a inclusão da comunidade (CHAGAS, 2000).

Convivem na atualidade museus com exposições que propiciam formas bastante distintas de comunicação com seus públicos. Há instituições com exposições muito mais voltadas à contemplação e ao encontro com uma cultura erudita, destacando as obras daqueles que são legitimados pela cultura dominante como "gênios" da arte ou da ciência. Museus de ciências, ainda hoje apresentam formas de organização em que há a exposição exaustiva de 
espécimes da natureza, nos remetendo aos museus de história natural do século XVII e XVIII, que possuíam importante papel na produção do conhecimento e tiveram influencia na constituição das disciplinas científicas. Outros museus, como os centros de ciências, são caracterizados pela intencionalidade educacional da relação com seus públicos, geralmente esses espaços não possuem acervos e os objetos expostos são construídos propositalmente para demostrar fenômenos e ensinar conceitos. Há ainda museus de arte à céu aberto, iniciativas de musealização do espaço que abriga expressões artísticas "mais populares" como por exemplo, o grafite.

Assim, com base nesses exemplos, poderíamos ilustrar que os conteúdos selecionados pelos museus, são vieses da cultura, considerando diferentes definições que ela pode assumir. Nos dois primeiros exemplos notamos a ênfase dada para o conteúdo, aproximando-se assim da definição de cultura tradicional, em que os currículos trariam recortes de um conceito de cultura que legitima o "espírito cultivado". Nos centros de ciências, ainda que haja foco no conteúdo, nota-se um outro viés da cultura na medida em que esses espaços só existem em função do seu papel na formação dos indivíduos, determinando seleções de conteúdos e práticas em função dos visitantes, aproximando-se da cultura escolar. No que se refere ao exemplo dos museus de arte à céu aberto, nota-se uma tendência à valorização de outras formas de expressão artísticas que se distanciam da cultura elitista. Museus ao ar livre e Ecomuseus ${ }^{9}$ permitem de acordo com Sandell (2003) acessar e legitimar os bens culturais das comunidades locais.

As definições patrimonial e universalista de cultura são as que apresentam mais relação com os objetivos e com o processo histórico de muitas instituições museais. A primeira - patrimonial, se relaciona com a ideia de construção histórica de patrimônio de uma comunidade humana particular, encontrando ressonância em museus históricos e nos diversos museus dedicados aos povos que ocuparam um território, como os museus indígenas e de temáticas afro. Já a acepção universalista que trabalha com a ideia de uma cultura humana

\footnotetext{
${ }^{9}$ Ecomuseus e museus comunitários surgiram na década de 1970 e tem suas referencias no movimento chamado de Nova Museologia. De acordo com Desvallées (1986, p.32) o ecomuseu seria um "território no qual as relações entre homem e natureza atravessam o tempo e o espaço, ele é composto por bens de reconhecido interesse científico e cultural, representativos do patrimônio da comunidade que ele serve"
} 
comum, poderia ser identificada com a própria definição de museu ${ }^{10}$. Cabe lembrar no entanto, que essa acepção de cultura não deve prescindir da reflexão sobre quem vai selecionar e o que vai ser selecionado para ser considerado universal.

Nessa breve apresentação vimos que há uma grande variedade de museus no que se refere à tipologia do acervo e aos conteúdos; somado a isso, há uma diversidade de práticas profissionais e formas de relação com o público, levando a um ampla gama de possibilidades pedagógicas realizadas por essas instituições. Considera-se que a experiência de visita a um museu é de natureza sócio-cultural-educativa e que é o resultado da interação de diversos fatores que incluem. Entre outros elementos, estão em interação os interesses e atitudes do visitante, suas experiências pessoais prévias, a proposta pedagógica do museu e suas características comunicacionais e de salvaguarda. Destaca-se também a complexidade da produção dos discursos das exposições e outras atividades educacionais realizadas por museus, que podem ser analisados desde um ponto de vista das relações de poder, como é proposto em um terceiro eixo de investigação das teorias críticas do currículo.

Esse terceiro eixo de investigação da análise crítica e da sociologia do currículo é o grande tema centralizador dessas teorias, pois foi a partir da compreensão de que tanto a educação como o currículo são espaços de poder, que se estruturaram parte das análises desse campo (MOREIRA e SILVA, 1995). Nessa vertente, os estudos se voltam para a identificação e análise das relações sociais de poder que constituem o currículo, enfatizando o caráter social e, portanto, político da constituição do currículo.

No Brasil autores como Bourdieu tiveram grande influencia sobre os estudos da área da Sociologia da Educação e também sobre os estudos do currículo. As teorias críticas também tiveram grande incidência entre os educadores brasileiros, principalmente a partir da década de 1980 (LOPES e MACEDO, 2002). Nesse período destacavam-se dois grupos teóricos nacionais: a pedagogia histórico-crítica ou pedagogia crítico-social dos conteúdos, de

\footnotetext{
10 "Museu é uma instituição permanente, sem fins lucrativos, a serviço da sociedade e de seu desenvolvimento, aberta ao público, adquiri, conserva, estuda, expõem e transmite o patrimônio material e imaterial da humanidade e de seu meio ambiente com fins educacionais e de deleite" (ICOM, 2006).
} 
Dermeval Saviani, e a educação popular, de Paulo Freire. Apesar de não serem especificamente teorias curriculares, ambas trouxeram em suas teorizações uma visão específica de currículo e de conhecimento que contribuíram para ampliação das discussões em curso (BARRETTO, 1998; SILVA, 2002; MOREIRA, 2000), fortalecendo a inserção das teorias críticas nos estudos realizados no País.

Também nessa época começam a se tornar presentes no cenário investigativo nacional as denominadas teorias pós-críticas de educação. De acordo com Silva (op. cit.) as teorias pós-críticas na área educacional incluem desde as teorias multiculturalistas de currículo até as críticas pós-estruturalistas do currículo.

Um aspecto importante apontado por Silva (op. cit.) para a compreensão dos impactos das teorias pós-críticas para os estudos curriculares, baseia-se nas discussões de Foucault sobre o conceito de "verdade". De acordo com Silva (1999), para Foucault não existe uma verdade que corresponda a uma realidade verificável, paradigma-base da construção dos currículos na escola da Modernidade. Assim, o mais importante não é o estabelecimento de uma suposta verdade e sim "o processo pelo qual algo é considerado verdade. A questão não é, pois, a de saber se algo é verdadeiro, mas sim de saber por que esse algo se tornou verdadeiro" (SILVA, op. cit., p.124).

O autor também aponta como as análises se voltam para o conceito de ideologia, no caso das teorias críticas, e de discurso, no caso das teorias póscríticas, evidenciando uma tensão no campo das teorias sociais críticas. Uma delas refere-se a noção de conhecimento: nas teorias pós-críticas o significado não é mais produzido a priori, mas sim determinado cultural e socialmente. Dessa forma, não é possível falar de um conhecimento "puro" que reflita o "melhor" da cultura humana, como é o caso nas teorias tradicionais, ou de um conhecimento que possa ser despido de seus condicionamento capitalistas e convertido a um estado original "ideal", como é o caso das teorias críticas. Para as teorias pós-críticas, examinar as relações envolvidas na produção do conhecimento passa pela caracterização dessas relações como campo de significação, (in)determinadas e conectadas com relações de poder. 
Considera-se que os museus têm uma função educacional explícita e comprovada tanto pelas suas práticas, como pela literatura que se debruça sobre o tema. A partir dessa premissa é possível afirmar que os processos educacionais que ocorrem no interior das instituições museais trazem uma série de elementos que constituem sua especificidade e que, da mesma forma que os currículos escolares, são passíveis de serem compreendidos enquanto produtores de sentidos/práticas de significação (SILVA, 1999). Essa compreensão da educação museal traz a tona uma série de possibilidade analíticas, que incluem desde a identificação e análise das relações de poder que constituem o "currículo" de uma determinada instituição museológica, até a compreensão do status epistemológico que o conhecimento possui dentro dos processos educacionais museais.

Em síntese, consideramos que as teorias curriculares podem auxiliar na compreensão dos processos educacionais que ocorrem nos museus. Acredita-se, portanto, que um primeiro passo para compreensão de suas especificidades, baseada nos questionamentos propostos pelas teorias curriculares (COSTA, 2002; SILVA, op. cit., 2002) resida, justamente, na compreensão da diversidade dessas instituições e nos processos que permeiam a construção de suas práticas educacionais.

Assim, pode-se questionar quais as concepções de cultura estão presentes nas exposições; quais são as condições de produção dos discursos; como as seleções, recortes, restrições, enfoques e tensões na produção dos discursos determinam os conteúdos e formas de leitura e compreensão da mensagem pelo público. Entre as diversas possibilidades teóricas, relacionadas ao campo curricular, selecionamos como embasamento desta pesquisa as teorias propostas pelo sociólogo da educação Basil Bersntein. Consideramos que as ideias propostas pelo autor, além de constituírem um quaro teórico robusto e construído ao longo de muitas décadas, permite compreender os contextos e práticas pedagógicas museais, do ponto de vista das seleções, recortes e possibilidades, levando em conta as influencias das relações e posicionamentos dos sujeitos sobre tais processos.

No contexto dos museus, a teoria de Basil Bernstein foi utilizada por 
Marandino (2001) na análise dos discursos de cinco exposições em museus de ciências. Além dessa autora, Martins (2011), buscou contribuir para a definição das especificidades epistemológicas da educação museal, analisando diferentes tipologias de museus, com base no conceito do dispositivo pedagógico. Citamos por fim, Pugliese (2015) que utilizou a teoria de Bernstein para analisar currículos e práticas do ensino superior, com foco na contribuição dos espaços de educação não formal para a formação de professores.

Foi a partir das contribuições teóricas da educação em museus e da teoria de currículo no contexto da sociologia da educação proposta por Basil Bernstein, que buscamos empreender a análise das bases que regem a produção dos discursos expositivos em exposições de imersão. Apresentamos no item seguinte parte das ideias de Bernstein pertinentes para a análise objetivada nesta investigação.

\subsection{A teoria de Basil Bernstein}

Basil Bernstein (1924-2000) é considerado atualmente um dos grandes sociólogos do século XX (DAVIES, 2001; SANTOS, 2003; MORAIS, 2004). Apesar desse reconhecimento e do elevado posto que ocupou na Universidade de Londres, por um longo período as ideias do autor foram bastante contestadas. De acordo com Arnot (2003), mudanças de visão sobre a teoria de Bernstein ocorrem com a publicação de Atkinson e colaboradores (1995). Esse trabalho trata-se de volume de celebração em honra de Basil Bernstein, contendo 12 artigos com uma enorme gama de abordagens da teoria do autor, com o viés comum das questões que envolvem a linguística e pedagogia.

A mudança da visão sobre as ideias de Bernstein pode ser notada também a partir das conferências organizadas com foco nos trabalhos do autor, tanto no Reino Unido, como em Portugal (ARNOT, 2003). De acordo com Santos (2003), depois do afastamento de Bernstein da universidade e depois de sua morte, cresceu o interesse por seus trabalhos, a exemplo da publicação "Tribute to Basil Bernstein: 1924 - 2000. Neste tributo colegas, colaboradores e acadêmicos de diferentes países prestam uma homenagem ao autor. 
Basil Bernstein foi professor emérito da cátedra Karl Mannheim de Sociologia da Educação no Instituto de Educação da Universidade de Londres. Suas publicações tem início no final da década de 1950 e se estendem até 2000.

Assim como Bourdieu, Michael Yong, Micahel Apple, entre outros, Bernstein costuma ser incluído no campo das teorias críticas do currículo e processos educacionais. $\mathrm{O}$ autor faz parte do movimento que ficou conhecido na Inglaterra como Nova Sociologia da Educação (NSE). No entanto, o próprio Bernstein demarca seu distanciamento em relação a esse movimento, afirmando que a NSE não chegou a efetivar aspectos de suas ideias e proposições. Como aponta Delamont (2000), Bernstein argumentava que sua sociologia da pedagogia caracteriza-se pela ausência de uma área de estudo em particular ou uma identificação profissional.

Delamont (op. cit.) afirma ainda, que Bernstein teria adotado um estruturalismo pós-durkeimiano, evidenciado na teoria da reprodução cultural que se coloca entre os campos do controle social, economia e política. Em alguns trabalhos de Bernstein é possível notar também, a busca em estabelecer relações com as teorizações produzidas por Foucault, nos quais se evidenciam os processos de controle e poder produzidos por meio dos discursos.

Segundo Delamont (op. cit.) a ênfase de Bernstein em princípios e regras estruturais sugere uma abordagem modernista que na década de 1990, diante das tensões entre essas abordagens e as pós-modernistas, podem ter colocado a teoria de Bernstein à margem. 0 autor afirma, no entanto, que a teoria de Bernstein pode ser definida como pós-estruturalista ou mesmo pós-modernista devido ao papel que atribui à linguagem, cujos princípios de classificação e enquadramento regulam as relações da sociedade.

Os trabalhos de Bernstein trazem uma combinação única entre poder e controle de todas as formas de transmissão educacional, considerando diversos campos que atuam na produção e transmissão da cultura, integrando macro e micro níveis da sociedade. Suas teorias têm caráter singular pois integram estrutura, cultura, linguagem e discurso (ARNOT, 2003).

0 modelo do discurso pedagógico constitui uma das principais e mais aplicadas ideias de Basil Bernstein. A proposta desse modelo é desvelar a complexidade dos discursos pedagógicos e das práticas escolares, considerados 
em permanente articulação com contextos sociais mais amplos. Vão nesse sentido as críticas que Bernstein fez às teorias reprodutivistas de Bourdieu, Passeron e Bowles, já que elas não se voltavam para as dinâmicas internas das práticas de forma integrada com as estruturas de poder e controle mais amplas da sociedade (SADOVINIK, 2001).

Como dito anteriormente, a teoria de Bernstein foi e é, ainda hoje, alvo de críticas. Uma delas diz respeito a caracterização da teoria do código como uma forma de teoria do déficit e da diferença, em que a origem do sucesso ou fracasso escolar estaria ligado às características do micro-contexto e não a uma distribuição social desigual. Outra crítica refere-se à relação do conceito de código elaborado com as condições sociais de sua produção e reprodução; e uma última crítica está relacionada ao nível de abstração e complexidade de sua teoria (ARON, 2005).

A teoria de Bernstein é famosa por seu caráter complexo, formal e criador. Abarca e relaciona de forma sistemática na mesma teoria, contextos diversos como família, trabalho e educação. A teoria abrange, também, níveis diferentes de regulação das relações, desde o estado, por meio do currículo e pedagogia ao nível dos sujeitos. Por fim, aponta para as possibilidades de variação e mudança, real ou potencial, entre e em todos os níveis do dispositivo pedagógico (BERNSTEIN e SOLOMON, 1999).

Revendo trinta e cinco anos de sua pesquisa, Bernstein ressalta a importância do trabalho empírico para fornecer elementos que permitem rever os conceitos teóricos (MOORE \& MATON, 2001). De acordo com os autores, essa afirmação decorre da produção de Bernstein ter sido desenvolvida tanto no campo teórico quanto no empírico, tratando a teoria como um processo, uma prática. Assim, para Bernstein não é possível imaginar ou representar a realidade, é preciso integrá-la na (re)construção teórica.

Para Morais e colaboradoras (2014), uma questão peculiar da obra do sociólogo e que expressa a sua posição epistemológica, é a possibilidade da relação dialética entre um modelo teórico e metodológico. Desta forma, a teoria norteia o empírico e este possibilita a mudança e ampliação da teoria, em uma constante relação dialética. A teoria de Bernstein permite criar uma linguagem 
que formule simultaneamente descrições sociológicas consistentes acerca das práticas de regulação e instrumentos conceituais de investigação.

Assim, a teoria de Bernstein é, atualmente, um modelo teórico, analítico e metodológico bastante empregado e discutido. Basil Bernstein tem tido um reconhecimento cada vez maior, isso é evidenciado por uma ampliação do número de pesquisas que utilizam suas ideias, realizadas por investigadores das mais diversas áreas do conhecimento, bem como, por meio dos vários simpósios internacionais dedicados a discussão das pesquisas que se valem da teoria do autor.

\subsubsection{Desenvolvimento das principais ideias de Basil Bernstein}

De acordo com Moore e Maton (2001), a trajetória de desenvolvimento das ideias de Bernstein podem ser representadas conforme o quadro 1.1. Neste estão evidenciados os principais focos do desenvolvimento teórico expressos nas suas publicações, seguindo uma escala temporal.

Quadro 1.1: Principais ideias de Bernstein ao longo da sua carreira, adaptado de Moore \& Maton (2001, p. 155).

\begin{tabular}{lll}
\hline Principal foco da teoria & $\begin{array}{l}\text { Principal década de } \\
\text { circulação da teoria }\end{array}$ & $\begin{array}{l}\text { Principal publicação } \\
\text { (Class, Codes and Control) }\end{array}$ \\
\hline $\begin{array}{l}\text { Transmissão/aquisição do } \\
\text { discurso pedagógico }\end{array}$ & Década de 1970 & Volume III - 1975 \\
$\downarrow$ & Década de 1980 & Volume IV - 1990 \\
$\begin{array}{l}\text { Estrutura do Discurso } \\
\text { Pedagógico } \\
\downarrow\end{array}$ & Década de 1990 & Volume V - 1996, 2000 \\
$\begin{array}{l}\text { Estruturas do conhecimento a } \\
\text { partir do qual o discurso } \\
\text { pedagógico é } \\
\text { recontextualizado }\end{array}$ & & \\
\hline
\end{tabular}

Segundo Morais (2004), os 5 volumes de Class, Codes and Control, publicados entre 1971 e 2000, mostram a evolução do pensamento de Bernstein. A autora ressalta que ele fez constantes revisões de suas ideias ao longo das publicações. Para Bernstein, 4 de seus trabalhos constituem os marcos de sua 
teoria. No artigo Classification and Framing, o autor aperfeiçoa as ideias da teoria sociolinguística que constituíram as primeiras propostas publicadas pelo autor. Em Codes, Modalities and the Process of Cultural Reproduction: A Model de 1981, Bernstein revê sua obra e formaliza uma teorização dos códigos. Além disso, as ideias presentes nesta publicação são elementos básicos que foram utilizados pelo autor para o desenvolvimento do modelo do discurso pedagógico.

O conceito de dispositivo pedagógico foi publicada inicialmente no artigo On Pedagogic Discourse de 1986. Em 1990, Bernstein publica uma versão mais estruturada sobre o discurso pedagógico em The structuring of pedagogic discourse (volume 4, de Classe, códigos e controle), que foi traduzido para o português em 1996, com o título "A estruturação do discurso pedagógico: classe, códigos e controle". Além das regras (distribuição, recontextualização e avaliação) que atuam nos processos de produção do discurso pedagógico, nesta versão foi desenvolvida uma forma de análise que incluiu as relações entre os modos de transmissão cultural, as ideologias e interesses, com os campos de produção e recontextualização dos discursos.

Os princípios internos da construção e da base social dos discursos, foi desenvolvida no artigo Vertical and Horizontal Discourse: an essay, publicado em 1999. Neste artigo, Bernstein faz uma análise da "forma" dos discursos que estão sujeitos a transformação pedagógica. De acordo com Bernstein (1999), é possível distinguir dois tipos de discursos (horizontal e vertical) de acordo com a forma de conhecimento que são realizadas neles. Para o autor essa distinção é essencial pois, o modo de aquisição desses discursos será diferente, tanto pela natureza distinta deles, quanto pela forma em que são adotados pelas pedagogias.

\subsubsection{Conceitos e modelos centrais da teoria de Bernstein}

Bernstein (op. cit.) aponta que qualquer teoria de transmissão cultural deve estar baseada em três critérios. 0 primeiro deles está relacionado à necessidade da teoria considerar e ser passível de análise em três níveis: o macro - institucional; o micro - interações; e os vários níveis do sujeito. Além de funcionar nesses níveis, é necessário que a teoria seja capaz de mantê-los unidos e de traduzir o macro no micro e vice-versa. 
Um segundo critério que diz respeito à consistência de uma teoria de transmissão cultural. É necessário o estabelecimento de regras que permitam distinguir manutenções, variações e mudanças nos níveis.

A descrição explicita dos sujeitos de análise é o terceiro critério apontado por Bernstein como essencial à uma teoria de transmissão cultural. É necessário ter o reconhecimento empírico do objeto e de sua descrição. Assim, a primeira coisa a se fazer é descrever de forma clara e sistemática o processo de transmissão e aquisição, para qualquer nível que esteja sendo trabalhado (escola, família etc.). As regras de descrição devem ser consistentes, esse é um aspecto deficiente em muitas trabalhos, pois há uma verdadeira separação entre teoria e prática. Essas regras precisam ser claras, de forma que a teoria possa especificar os contextos, e também os procedimentos para a descrição e interpretação. Isso porque, os princípios de descrição irão atuar seletivamente sobre aquilo que será convertido em dados, ou seja, sobre a interpretação.

A teoria de transmissão cultural proposta por Bernstein (1990), explicita o processo mediante o qual uma distribuição de poder e princípios de controle, são traduzidos em princípios de comunicação. Estes estão distribuídos diferentemente entre as classes, e durante o processo de reprodução cultural, ocorre o posicionamento e oposição das classes e entre as classes.

Os princípios de comunicação têm dois papeis principais: posicionam o indivíduo em uma classe e em relação as outras classes. Com isso, torna-se essencial mostrar como se dá a tradução do poder e controle em princípios de comunicação, que serão justamente os portadores e transmissores do poder e controle.

\subsubsection{Código}

Um conceito essencial relacionado aos princípios de comunicação é o código. De acordo com Bernstein (1996), o código é um princípio regulador que atua na seleção e integração dos significados relevantes, na forma com que é realizado e nos contextos de sua realização. De acordo com Morais e Neves 2007b, o código regula a relação entre contextos e origina princípios orientadores da produção dos textos adequados a cada contexto. Desde as suas 
primeiras obras sobre linguagem, Bernstein se refere ao código (restrito e elaborado), como um princípio regulador que está na base dos sistemas de mensagens. É importante destacar, que Bernstein (1990), considera o currículo, a pedagogia e a avaliação, como sistemas de mensagens. 0 currículo define quais são os textos ou conhecimentos válidos; a pedagogia define formas de transmissão legítimas do conhecimento e por fim, a avaliação define o que conta como a realização válida do conhecimento.

O código é definido pela relação entre a orientação de codificação e a forma como essa orientação é realizada. A orientação restrita está relacionada ao contexto e tem características particularistas, já os códigos elaborados independem do contexto e são universalistas. A forma como a orientação de codificação é realizada depende da distribuição de poder e dos princípios de controle que regulam as relações sociais e os contextos pedagógicos. 0 código restrito caracteriza a socialização primária e é acessado pelos indivíduos de qualquer classe social. Ele está diretamente ligado a base material e limita o desenvolvimento de recursos que permitam que os indivíduos reconheçam e realizem os conteúdos e práticas legitimas e relevantes independentemente do contexto.

De acordo com Morais e Neves (2007b), a teoria de Bernstein propõe que o discurso e prática pedagógica oficial, tais como os currículos e materiais escolares, institucionalizam uma orientação elaborada. Já os discursos e práticas pedagógicos locais na família, podem ter uma orientação restrita ou elaborada, conforme a posição da família na divisão social de trabalho. Contudo, a orientação restrita não é uma categoria imutável, a mudança para uma orientação elaborada pode ocorrer pelo acesso à educação formal e também pelo acesso a contextos diferenciados, como museus e outras agências que possuem estrutura organizada (partidos políticos e sindicatos).

Bernstein (1996) considera que existem diferenças nos códigos de comunicação devido à classe social. Essas diferenças refletem as relações de classe e de poder na divisão social do trabalho, família e escolas. O conceito de classes sociais para Bernstein está ligado ao conceito de divisão social do trabalho de Durkheim, assim a classe social pode ser entendida pela posição que as pessoas ocupam na divisão do trabalho. 
Mas como o poder e controle se traduzem em princípios de comunicação, que posicionam o indivíduo em uma classe e em relação as outras classes? Tomando um conjunto de categorias e compreendendo-as como uma divisão social de trabalho, podemos afirmar que esta divisão depende do tipo de relação estabelecida entre essas categorias. As relações de poder são reproduzidas, assim como a divisão de trabalho é reproduzida, por meio das relações sociais entre os sujeitos e os grupos, fazendo a manutenção de cada indivíduo em sua categoria. Quanto mais especializada for uma categoria, maior será sua diferença em relação a outra categoria, e maior é a probabilidade de ter sua própria voz. Assim, as categorias constituem "vozes" e essas limitam aquilo que pode constituir uma mensagem legitima. As relações sociais que se estabelecem nos diferentes contextos, posicionam as categorias e por sua vez as "vozes", atuando portanto, na regulação da mensagem. De acordo com Bernstein, há um nexo entre categoria, voz e mensagem e é por meio dos códigos que são adquiridas uma determinada voz e uma determinada mensagem.

\subsubsection{Classificação e enquadramento}

Para compreender como se dão as relações entre categorias, Bernstein (1990) apresenta o conceito de classificação. Se uma categoria é especializada de forma diferente a outra categoria, considera-se que esta relação é fortemente classificada. Isso significa que há um grande espaço entre elas, denominado por Bernstein como isolamento, que é criado e mantido pelas relações de poder. Qualquer mudança na categoria, significa romper o isolamento e expor as relações de poder. Porém, em algumas situações as categorias não são tão especializadas, havendo uma classificação fraca. Aqui as relações de poder existem, mas são muito menos explícitas.

Em nível superficial a classificação estabelece ordem e também quem é o dono da ordem. Isso ocorre de duas formas: objetivamente pois a classificação cria ordem; e subjetivamente, pois gera o isolamento entre categorias que possuem um determinado posicionamento devido ao código. É o isolamento que suprime as contradições e dilemas da própria classificação, garantindo sua reprodução. Isso quer dizer que as contradições da ordem estabelecida vivem 
dentro de cada um, mantendo um potencial para a mudança, no entanto o isolamento, produzido pelo poder, mantem menos evidentes essas contradições.

A classificação é considerada forte quando as fronteiras entre as categorias são evidentes, já a classificação fraca refere-se ao esbatimento dessas fronteiras. Nas escolas há categorias de discurso representadas por disciplinas fortemente classificadas, com forte isolamento entre elas. Nessa situação, na comunicação entre os professores há relações de poder que não estão vinculadas por relações de trabalho. Isto porque o professor está amarrado em seu discurso especializado. Se a classificação for enfraquecida e os discursos integrados, os professores estariam unidos por meio das relações de trabalho, havendo assim uma relação de contra poder (BERNSTEIN, 1990).

O princípio de classificação estabelece a voz de cada um. 0 indivíduo possui sempre a voz de vários discursos, ainda que não tenha a mensagem de todos eles. 0 poder constitui os princípios de comunicação, assim para mudar a classificação é necessário mudar a as relações de poder. Porém há um controle que regula essa comunicação. 0 poder está relacionado à classificação e o controle à comunicação.

Tomando as categorias e suas práticas, sabendo que essas são reguladas por princípios de comunicação, pode-se dizer que a comunicação se refere a uma prática pedagógica, em que há relações entre transmissor e adquirente, entre os transmissores, entre os adquirentes e ainda, entre as agências. Nessas relações há sempre um controle que regula a comunicação nas relações pedagógicas. Para Morais e Neves (2007b), Bernstein indica que os princípios de controle estabelecem a forma das relações sociais entre categorias, ou seja, instituem os princípios de comunicação de uma determinada mensagem.

O enquadramento é o princípio de comunicação, que regula quem tem o controle do que é transmitido, do que é recebido e do que pode ou não ser transmitido na relação pedagógica. Quando há forte enquadramento é o transmissor quem controla os princípios de comunicação, já quando é fraco há um espaço aparente para que o adquirente tenha controle sobre tais princípios. Vale ressaltar, que o uso do aparente está ligado a ideia do autor de que o enquadramento fraco não leva de fato a igualdade de controle, podendo mesmo mascarar o poder. 
O enquadramento regula portanto, a estrutura básica da comunicação e sua lógica interna, definindo regras de comunicação especializadas. Nesse sentido, Bernstein (1990) aponta que poderá haver exclusão de crianças na escola justamente porque não compartilham dessas regras.

No contexto da década de 1960, Bernstein procurou compreender as razões do fracasso escolar de crianças e jovens da classe operária. Por meio do desenvolvimento do conceito de código, queria chamar atenção para a enorme contradição entre código elaborado posto pela escola e o código restrito das crianças operárias, que poderia ser a origem do seu fracasso escolar.

De acordo com Bernstein (op. cit.), as crianças da classe trabalhadora geralmente não adquirem as regras de enquadramento dos códigos elaborados da escola, assim não podem produzir um texto pedagógico legítimo. Isso estaria relacionado ao fracasso escolar.

Segundo Morais e Neves (2007b), a forma de especialização da comunicação educacional é regulada pelo código pedagógico. Ele é um princípio que modela o currículo, pedagogia e avaliação. Para Bernstein (1990), há diferentes tipologias de currículo. Em um extremo estão aqueles chamados de currículos de integração e no outro os de coleção. A partir desses tipos de currículo, Bernstein caracteriza os códigos a estes subjacentes, utilizando os conceitos de classificação e enquadramento. Assim, o código de coleção possui classificação forte, há fronteiras claras entre os conhecimentos. 0 enquadramento é também forte, pois há poucas possibilidades de controle do que é transmitido e adquirido. Já o código de integração, possui fraca classificação, o isolamento entre os conhecimentos é reduzido. 0 enquadramento tende a ser fraco, uma vez que há mais opções de controle para os agentes nas relações pedagógicas.

No sentido de compreender as possibilidades pedagógicas, disponíveis no sistema escolar, e como elas operam para as diferentes classes sociais, Bernstein publicou entre 1975 e 1990 diferentes versões do texto "Classe social e pedagogias visíveis e invisíveis". Nestes trabalhos analisou as diferenças existentes entre dois modelos de transmissão pedagógica e as implicações dessas práticas para as diferentes classes sociais. Pedagogias marcadas por forte classificação e forte enquadramento, foram denominadas pedagogias visíveis. As 
chamadas pedagogias invisíveis, são aquelas caracterizadas pela fraca classificação e fraco enquadramento. Apesar de serem modalidades aparentemente opostas Bernstein (1990), afirma que em ambas reproduzem as relações de classe. Com isso, nenhum dos modelos de transmissão pedagógica poderiam eliminar a reprodução das desigualdades de classe.

Morais e Neves (2001), Morais (2004), Morais e colaboradoras (2014), afirmam com base na teoria de Bernstein e das pesquisas realizadas pelas autoras no ensino de Ciências, que uma prática pedagógica mista, com elementos das pedagogias visíveis e invisíveis, podem gerar oportunidades, aos alunos socialmente desfavorecidos, de acesso aos códigos restritos e ao conhecimento válido na sociedade.

As pesquisadoras argumentam em favor de uma prática mista em que a comunicação entre professores e alunos, e o tempo destinado à aprendizagem tenham enquadramento fraco. Isso significa que a relação transmissor e aquisidor deve ter uma comunicação aberta, permitindo maior apoio aos alunos desfavorecidos. Outra forma de apoio a estes alunos pode ser proporcionada por meio de tarefas diferenciadas, que respeitem o ritmo de aquisição individual. Já os critérios de avaliação devem ter enquadramento forte, ou seja, deve-se explicitar o texto considerado legítimo. Este ponto é crucial para o acesso das crianças desfavorecidas, pois critérios de avaliação mais explícitos, permitem que os professores e pais tenham informações mais precisas sobre o progresso dos alunos. No que se refere a classificação, as autoras propõe o estabelecimento de relações dentro e entre as disciplinas, ou seja, que a intra e interdisciplinaridade sejam fracamente classificadas.

As pesquisas conduzidas pelo grupo de Estudos de Sociológicos de Sala de Aula (ESSA), mostram que a prática pedagógica pode atenuar as diferenças do nível socioeconômico dos alunos, sem que seja necessário diminuir a complexidade de conteúdos. Pelo contrário, os trabalhos do grupo aplicando o conceito de exigência conceitual para análise de currículos, materiais pedagógicos e práticas (FERREIRA e MORAIS, 2002; CALADO e NEVES, 2012; CALADO, NEVES, MORAIS, 2013), consideram que a complexidade dos conceitos e competências deve ser alta, oportunizando a todos os alunos o acesso ao conhecimento científico valorizado pela comunidade científica e pela sociedade 
em geral.

Com base em alguns dos pressupostos da teoria de Bernstein, Young (2007) argumenta que os indivíduos da "elite" tem mais acesso ao código elaborado, e portanto à aquisição do "conhecimento poderoso", independentemente do contexto. Young diferencia o "conhecimento dos poderosos", aquele que é definido pelos indivíduos que detêm o conhecimento, e o "conhecimento poderoso", que se refere especificamente ao papel do conhecimento em fornecer explicações confiáveis ou novas formas de pensar a respeito do mundo (YOUNG, op. cit., p.1294).

A escola é de forma principal, uma agencia de transmissão cultural ou de conhecimento. Neste contexto alguns conhecimentos são mais valiosos que outros, e diferenciam-se daqueles não escolares. Para o autor a escola pode permitir o acesso a conhecimentos para aqueles indivíduos que não poderiam adquiri-lo em casa, na sua comunidade ou local de trabalho. Da mesma forma que a escola, guardadas as devidas especificidades, os museus constituem espaços de socialização que contribuem para o acesso ao conhecimento poderoso. De acordo com sua função social dos museus na transmissão da cultura legitima, valorização do patrimônio material e imaterial e na construção de conhecimentos e significados, reforçamos o importante papel dessas instituições para o acesso aos códigos elaborados e, em última análise, a contribuição para as possíveis mudanças das relações de poder na sociedade.

Dessa forma, é preciso ressaltar que o conhecimento é transformador, mas dado que a própria sociedade é desigual, a educação formal não pode ser o único viés de transformação (YOUNG, 2011). Com isso, apontamos a relevância de identificar, descrever e compreender outros contextos educativos, que podem desempenhar importante papel para o acesso de todos ao "conhecimento poderoso".

\subsubsection{O discurso pedagógico}

$\mathrm{Na}$ obra "A Estruturação do discurso pedagógico: Classe, códigos e controle (1996), Bernstein propõe a hipótese de que quanto mais abstratos forem os princípios relacionados à produção, mais simples será a divisão social 
do trabalho e mais complexa será a divisão social relacionada ao controle simbólico.

Para trabalhar a hipótese, Bernstein traz alguns fundamentos importantes, como as ideias acerca da relação entre produção (economia) e cultura propostas por Marx. A ideologia marxista de que a existência determina a "consciência" carece de especificações mais consistentes das relações entre os discursos, relações sociais e divisão do trabalho, bem como, dos processos de transmissão que geram as relações entre consciência e ideologia. Bernstein ressalta que apesar das ideias de Foucault contribuírem para evidenciar as possibilidades de "posicionamento discursivo do sujeito", não são analisadas de forma sistemática as agências, agentes e suas relações, tampouco a educação e suas modalidades de transmissão.

Para iniciar o aprofundamento sobre a hipótese traçada, Bernstein afirma que o controle simbólico conduz a formas de distribuição do poder, expressas pelos discursos que também são moldados pelas relações de poder. As agências e agentes são constituintes do campo de controle simbólico, que regulam os meios, contextos e possibilidades dos recursos discursivos. Os componentes desse campo se especializam e dominam discursos específicos de comunicação, que regulam as relações sociais, atuando também sobre as formas de consciência.

O campo de controle simbólico está geralmente relacionado aos códigos discursivos e o campo econômico aos códigos de produção. Neste segundo campo encontram-se os agentes que atuam na regulação dos contextos e possibilidades dos recursos físicos.

Há diferentes categorias de agentes dos códigos discursivos dominantes. Quando há uma relação direta entre recursos físicos e os códigos discursivos, o controle simbólico será realizado preponderantemente pela atuação dos agentes no campo da produção, funções de administração, gerenciais e financeiras. Já quando os códigos discursivos dominantes estiverem diretamente relacionados aos recursos discursivos, o controle simbólico será efetuado pela atuação de médicos, sacerdotes, cientistas. Há que se considerar também os agentes de controle simbólico que atuam no campo da produção e aqueles que atuam em empresas ou via textos que são contratados por agências. Nesse último caso, os agentes dominam a produção porém, não tem controle sobre o texto, havendo aí 
“tensões intrínsecas do encontro de agentes especializados” (BERNSTEIN, 1996, p. 193).

Os agentes de controle simbólico tem funções normalizadoras e que são legitimadoras do próprio discurso. Bernstein propõem uma divisão de trabalho do controle simbólico, que abarca agentes e agências, de acordo com as funções nesse controle: reguladores (jurídico, religioso, polícia), reparadores (médicos, psiquiatras, assistentes sociais), reprodutores (professores), difusores (meios de comunicação), modeladores (geradores de mudanças simbólicas), executores (administração pública).

Algumas oposições podem surgir da atuação dos profissionais no campo da produção ou do controle simbólico; em geral os agentes que atuam no campo do controle simbólico tendem a querer aumentar os gastos públicos, enquanto o inverso ocorre com aqueles que atuam no campo da produção. Assim, de acordo com Bernstein, ter uma identidade profissional comum pode ser menos importante do que a localização e posição dele no campo.

0 autor destaca que a educação tem importante papel na construção da consciência dos agentes dos dois campos, ressaltando os aspectos da relação entre produção e educação. Na análise entre produção e educação proposta pelo autor o foco está nos agentes de controle simbólico que atuam no sistema educacional. Bernstein explica ainda, que os campos da educação e produção podem ter graus diferentes de classificação, ou seja, os contextos dos campos podem ser mais ou menos distintos para a formação da consciência. Quando eles são fortemente classificados seus princípios são bem separados, já quando essa classificação é fraca, os campos são menos distintos, havendo princípios comuns.

Bernstein questiona qual campo (educação ou produção) seria a influência primária na formação da consciência, apontando que quando essa influência tende para a produção, tanto para a classe dirigente como para a operária, a educação será a reguladora de comportamentos e condutas. Já quando o controle simbólico é a principal influência sobre a formação da consciência, surgem incompreensões e suspeitas por parte das outras classes, abrindo espaços para a resistência e oposições.

Com isso, a hipótese anterior é complementada com a ideia de que quanto mais abstratos os princípios da produção, mais simples será a divisão social do 
trabalho e mais complexa a divisão social do trabalho de controle simbólico. Bernstein utiliza como exemplo a divisão de trabalho do séc. XX, no qual os princípios de produção ficaram cada vez mais abstratos, levando a geração de sistemas de comunicação auto-reguladores e com uma complexidade maior dos mecanismos de controle.

De acordo com o autor, no pré-capitalismo não havia vínculo entre produção e educação, o condutor para a produção e reprodução de práticas manuais estava na família. 0 vínculo entre o controle simbólico e a educação era forte, representado pela igreja e universidades.

No capitalismo competitivo, em meados do século XX, é possível ver o início do vínculo entre produção e educação, o discurso instrucional começa a ser visto como forma de criação de força de trabalho dócil e com moral apropriada. Há também um aumento da complexidade na divisão social do trabalho de produção.

Apenas no capitalismo de transição, principalmente na segunda metade do séc. XX, é possível identificar o vínculo entre produção e educação mais forte, originado das novas tecnologias e forças de produção, bem como, das ideias de mobilidade social por meio da educação e igualdade de oportunidades (ainda que essas ideologias não sejam reais em seus efeitos, principalmente para as classes menos favorecidas).

Nas últimas décadas do século XX, a educação é vista como muito abstrata e há um aumento da educação vocacional, com currículos e regulação mais fortemente ligados ao campo econômico. Há também um aumento no papel do estado via discursos e agências de regulação.

No entanto, o final do século XX nota-se também a diminuição da economia e da crescente complexidade da divisão social do trabalho. Passa-se então à ideologia de mercado, as agências de regulação tornam-se suspeitas por conta do coletivismo estatal, o estado se retira da produção e também, facilita o acesso de agentes oriundos do campo da economia para gerenciar o campo do controle simbólico. 0 mercado passa a ser orientador na seleção dos discursos, pesquisa e nos programas educacionais dos diferentes níveis. Novos instrumentos de controle do estado sobre a educação passam a ser utilizados, como as avaliações 
externas e também a avaliação dos pesquisadores da universidade por produtividade acadêmica.

Afonso (1999) traz a ideia da educação de quase-mercado, pois apesar dos mercados substituírem o monopólio do estado , a educação não fica a deriva da livre demanda pois há um papel de regulação do campo do estado sobre o currículo, materiais pedagógicos e práticas. É no contexto, do quase-mercado e associado a uma nova direita que surgem novas formas de gestão pública ou gerencialismo. Elas visam aumento de eficiência na administração pública, trazem princípios de mercado para a educação como a premiação pelo desempenho em avaliações, ênfase no produto e não no processo.

De acordo com Bernstein (1996), a ideologia de mercado leva a um novo conceito de conhecimento, que é fluido e pode gerar vantagens e lucro, ele passa a ser dinheiro. Assim, o conhecimento é desumanizado e dissociado das pessoas, que podem a qualquer tempo ser substituídas. Na época medieval o conhecimento e quem o detinha estavam integrados, agora formam dois mercados distintos.

Ocorre também no séc. XX, uma mudança em relação a própria forma de organização do conhecimento. Se antes existiam disciplinas com discursos especializados, e que formavam um campo intelectual com práticas, textos e regras próprias, durante o capitalismo de transição é possível notar uma mudança em direção ao que o autor denomina regiões. Elas seriam a recontextualização das disciplinas em unidades maiores e operariam também na interface entre elas e as tecnologias que propõem. Ocorre assim, um enfraquecimento na classificação dos discursos e formação de entidades profissionais.

$\mathrm{Na}$ conjectura realizada por Bernstein para o séc. XXI, denominado de capitalismo reorganizado, deverá ocorrer uma simplificação na divisão social do trabalho de produção, por conta da existência de um pequeno conjunto de funções especializadas na execução ou nas tecnologias. 0 autor considera, no entanto que possa ocorrer uma nova ascensão dos trabalhos manuais e artesanais, bem como, a expansão do campo cultural, de suas agências e agentes. O campo de controle simbólico deverá crescer em complexidade, podendo 
assumir novas funções normalizadoras, ao mesmo tempo em que poderá representar o lugar "do novo" e das possibilidades de mudança.

As possibilidades de mudança decorrem do fato de que o dispositivo pedagógico que produz e reproduz o controle simbólico (agora mais complexo pelo enfraquecimento da divisão social do trabalho) e suas modalidades, disponibiliza princípios que moldam e remoldam a consciência. Notamos assim, que o vínculo entre educação e controle simbólico é cada vez mais forte, e o vínculo com a produção mais especializado.

O dispositivo pedagógico, de acordo com Bernstein (1996), é um conceito que pretende ser capaz de especificar os princípios próprios à produção, reprodução e mudanças do discurso pedagógico. Uma teoria capaz de fornecer "a gramática intrínseca do discurso pedagógico" (p. 254).

Para o autor, as pesquisas acerca do discurso que vem sendo realizadas pela sociologia da educação, dão ênfase à mensagem do discurso ou desse como meio para outras vozes (classe, gênero, raça). Mas não há explicações sistemáticas dos princípios que constituem a prática comunicativa de transmissão e aquisição destes discursos, atividades estas centrais da escola. Ainda que a nova sociologia da educação tenha se proposto a estudar o currículo e as formas de transmissão e aquisição do conhecimento, suas produções não conseguiram atingir esses objetivos. Por sua vez, as teorias da reprodução estudam o discurso como apenas um condutor das relações de poder externas a ele, deixando de lado as características próprias desse condutor que certamente influenciam na mensagem transmitida.

A ideia de dispositivo pedagógico tem por base as teorias da reprodução cultural, da resistência e pedagogia crítica. Bernstein (op. cit.) afirma que a escola retém e aumenta o recorte na cultura que é produzido pelas relações de classe, atuando portanto na legitimação da reprodução dessas relações. Contudo, o autor não considera que a escola seja um mero condutor destas relações. Ele reconhece que as mensagens reproduzem as classes, mas aponta também para outra distorção, que leva, por meio dos processos de recontextualização, a uma menor valorização da representação da cultura, das práticas e da consciência dos grupos dominados. 
Como já apontado anteriormente, Bernstein considera que uma teoria da sociologia da educação deve trazer a possibilidade de tradução do micro no macro e vice-versa. 0 modelo do discurso pedagógico, presente na teoria do dispositivo, traz diferentes possibilidades de análise acerca do texto pedagógico privilegiante $^{11}$ (currículo ou prática dominante). Uma delas teria como ênfase as relações com o texto no nível micro (classe, gênero) e/ou macro (trabalho, estado). A outra análise teria como foco a relações interiores do texto, seja no nível macro (sistema educacional) ou micro (sala de aula).

As relações com o texto podem dar ideia sobre as possibilidades de inclusão e exclusão dos sujeitos em relação aos textos. Essas possibilidades estão ligadas à ideia de habitus, remetendo-nos à família, comunidade e grupo de colegas que constituem a prática pedagógica local. Alguns indivíduos estão posicionados de forma a se apropriar do texto legitimo, pois receberam em casa alguma versão da prática pedagógica oficial. Caso essa prática não seja a dominante na família, o adquirente poderá estar posicionado em desigualdade ou mesmo em oposição ao texto.

Já as relações no interior do texto, referem-se às regras internas de constituição desse texto (suas especificidades, formas de transmissão, contextualização, aquisição e mudança). No nível micro essas regras regulam as relações entre os agentes e seus contextos. No nível macro regulam a constituição dos discursos pedagógicos dos quais o texto privilegiante foi derivado, referem-se as relações de poder e controle do estado. Vale ressaltar que para Bernstein são justamente essas as relações inexploradas pelas teorias da reprodução cultural, resistência ou transformação.

Para Bernstein (1996), o dispositivo pedagógico assim como o linguístico são constituídos por regras relativamente estáveis (condutor), porém as regras que agem sobre a comunicação que é derivada dos dispositivos, são variáveis e contextuais (conduzido). Isso não quer dizer que qualquer um dos conjuntos de regras seja neutro em relação às ideologias. As regras do dispositivo pedagógico participam da divulgação ou limitação de formas de consciência. Porém,

\footnotetext{
${ }^{11}$ Bernstein propõe que o conceito de autonomia relativa tem um papel fundamental na produção e condução do discurso pedagógico (dos seus textos, práticas e na sua transmissão). Mas que esse conceito é utilizado aqui de forma diferente das teorias da reprodução cultural, nas quais ele apontava para a criação da "ilusão da neutralidade da educação". Neste ensaio, Bernstein aponta que o conceito diz respeito a todo o discurso pedagógico "como uma arena de conflito, local de luta e apropriação".
} 
diferentemente do dispositivo linguístico, o pedagógico pode produzir uma forma de comunicação que subverta as regras principais dele.

0 dispositivo pedagógico proporciona os princípios que regem o funcionamento inerente ao discurso pedagógico. Ele atua por meio de regras distributivas, recontextualizadoras e avaliativas, hierarquicamente relacionadas. Essas regras atuam nos processos que levam à especialização de formas de consciência, ou seja, podem fornecer a compreensão de como a distribuição de poder e princípios de controle posicionam, reposicionam e opõem as formas de consciência e prática.

Bernstein (1996) afirma que atualmente o controle sobre o conhecimento impensável (aquele menos diretamente ligado ao contexto imediato, relacional e que necessita de códigos elaborados para ser acessado) estão ligados aos níveis superiores de ensino, nos quais há mais produção do que reprodução de conhecimento. Já o pensável (conhecimento mais diretamente relacionado à base material) está situado nos níveis inferiores do sistema educacional, ligado mais a reprodução do que produção do conhecimento.

As regras distributivas ou de distribuição regulam a especialização das formas de consciência de maneira diferenciada para os diversos grupos, controla assim o que pode ser transmitido (significados) e portanto, o acesso ao impensável. Elas agem também sobre quem pode "pensar" o impensável, transmitir o conhecimento e as condições dessa transmissão. As regras de distribuição constituem portanto, um principio de classificação que regula as relações entre a distribuição de poder, o conhecimento e as formas de consciência.

A aquisição e transmissão diferenciadas são efetuadas por meio de uma comunicação especializada: o discurso pedagógico, que pode ser considerado como um princípio pelo qual um discurso sai de seu contexto de origem e é selecionado, sendo colocado em uma base reguladora, moral e de comportamentos. Assim, segundo Morais e Neves (2007b), as regras recontextualizadoras ou de recontextualização, regulam a constituição dos discursos pedagógicos específicos, quanto ao "que" - discursos a serem transmitidos, e quanto ao "como" da transmissão-aquisição - discursos que regulam este processo. 
Segundo Bernstein (1996), o discurso pedagógico não tem um discurso próprio, mas é sim um princípio de apropriação de outros discursos, deslocandoos de suas práticas e contextos originais e colocando-os de acordo com os próprios enfoques e seleções, além de introduzi-lo em um novo ordenamento temporal. No processo de deslocamento e recolocação, o discurso original perde a base social de sua prática. Em uma primeira etapa, os discursos passam pelo processo de descontextualização, no qual o texto sofre mudanças de posicionamento em relação a outros textos, seleções, simplificações, condensações e elaborações para por fim, ser reposicionado e refocalizado.

Por fim, as regras de avaliação, reguladas pelas regras recontextualizadoras, atuam na especialização dos discursos dentro da escola ou contexto educacional, bem como, regulam a atuação dos executores das práticas pedagógicas. Ressalta-se com isso, que não são apenas as regras recontextualizadoras que fazem seleções de significado e formas, uma vez que as regras distributivas agem sobre o que pode ser transmitido e as avaliadoras regulam a especialização do texto no interior da escola ou em outros contextos educacionais como os museus.

Por meio das regras distributivas, recontextualizadoras e avaliativas, o dispositivo pedagógico estabelece a relação entre poder, conhecimento e consciência. 0 dispositivo pedagógico é, de acordo com Bernstein (1996), um "governador simbólico da consciência", abrangendo as condições para a produção, reprodução e transferência da cultura. A eficácia dele é limitada tanto internamente como externamente. Ao transformar os discursos em discursos recontextualizados, o princípio do dispositivo gera espaço para a atuação das ideologias, pois como dito anteriormente, a própria distribuição de poder acaba por gerar espaços de contestação de sua legitimidade. Portanto, o dispositivo contem o potencial de sua própria transformação.

0 modelo do discurso pedagógico inclui três níveis fundamentais de análise: geração, recontextualização e transmissão. A figura 1.1 evidencia a complexidade de relações entre diferentes campos e contextos que determinam o discurso pedagógico e portanto, o discurso expositivo. No contexto primário, produção do discurso pedagógico, encontram-se os dois primeiros níveis de 
análise - geração e recontextualização. 0 terceiro nível de análise, transmissão está relacionado ao contexto da reprodução do discurso pedagógico.

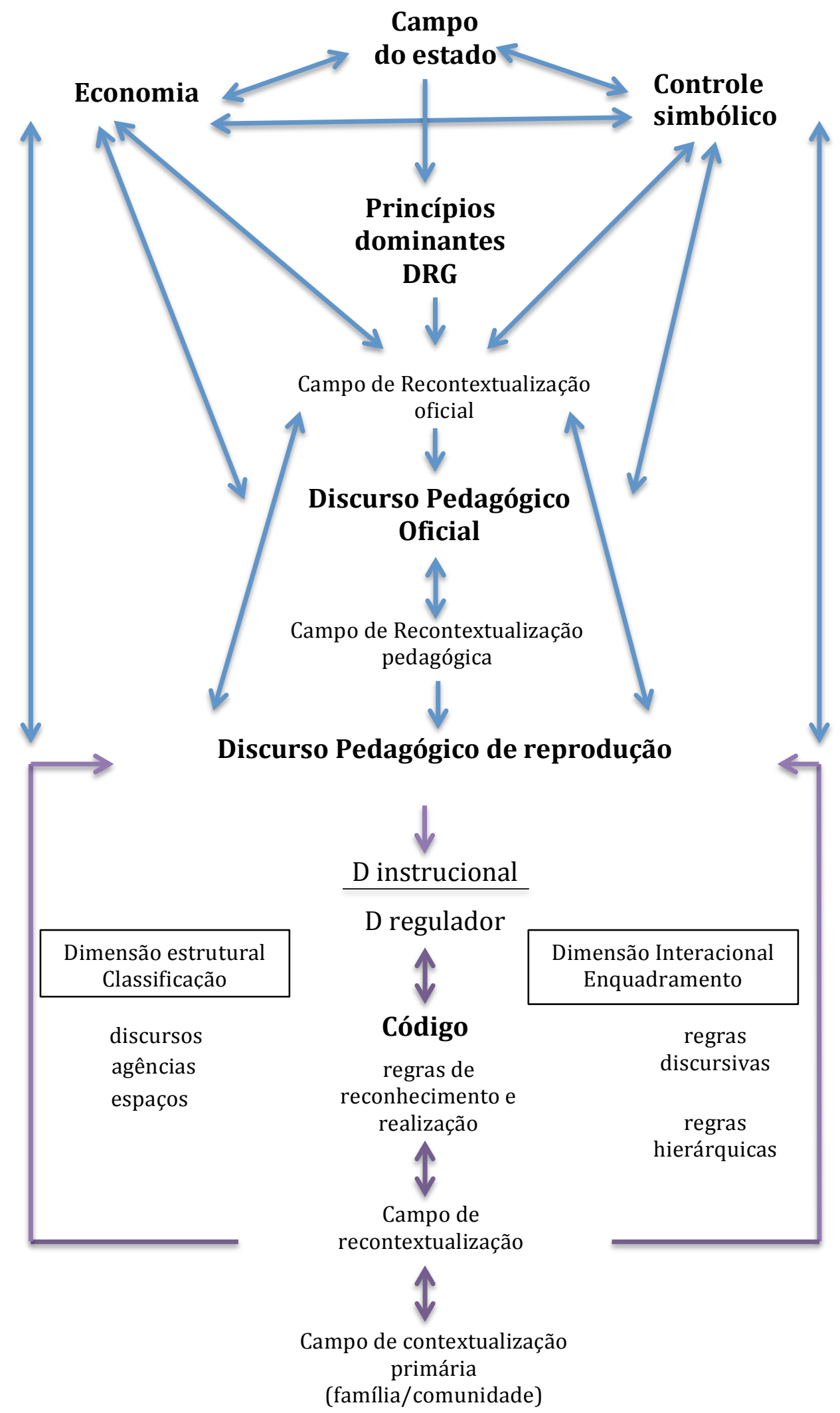

Figura 1.1: Modelo do discurso pedagógico, adaptado de MORAIS e NEVES (2007b). 
O contexto da produção do discurso, ao nível da geração do discurso, constitui o campo intelectual do sistema educacional. 0 processo de produção e posicionamento do discurso pedagógico é chamado de contextualização primária, na qual novas ideias são criadas, modificadas, bem como, discursos especializados são produzidos. A este contexto estão relacionadas as regras distributivas. O nível da recontextualização do discurso é composto pelos campos recontextualizadores, nos quais agentes e práticas atuam na produção do discurso pedagógico oficial e de reprodução. Vale ressaltar que processos de recontextualização e campos recontextualizadores podem também ocorrer no contexto de reprodução do discurso pedagógico. Já o contexto secundário (reprodução do discurso) está relacionado à reprodução seletiva do discurso, compõem o campo da reprodução, que possui vários níveis, práticas, agências e agentes. A este contexto de reprodução estão relacionadas as regras avaliativas.

Como vimos, a partir do final do séc. XX, a produção cultural está relacionada com o campo da economia e com o campo do controle simbólico. 0 primeiro está relacionado à produção de bens e de serviços e à distribuição e circulação de capital econômico. 0 campo do controle simbólico é aquele em que ocorre a criação, distribuição, reprodução e mudança legítimas da consciência por meio de princípios de comunicação. Neste campo atuam instituições, agências e agentes do "campo intelectual".

Também ressaltado anteriormente, o contexto de reprodução do discurso posiciona e opõem os sujeitos - transmissores e adquirentes, em referência a um conjunto de significados (discursos recontextualizados), e de relações sociais (práticas reguladoras da transmissão). 0 código pedagógico está subjacente aos significados e às relações sociais que são implicitamente adquiridos pelos indivíduos.

A produção do discurso pedagógico oficial (DPO), é o resultado de relações que estabelecidas nos níveis de geração e de recontextualização do discurso regulador geral (DRI). Este discurso é resultado das relações entre o campo do Estado e os campos da economia e controle simbólico, ele possui os princípios dominantes da sociedade. Ao nível da geração (I), o campo do Estado funciona legitimando os princípios de distribuição social do poder e do controle que são incorporados no discurso pedagógico oficial (DPO). Vale notar que este discurso 
não é resultado direto dos princípios dominantes da sociedade, pois eles sofrem um processo de recontextualização. Relacionados diretamente a este processo encontram-se o campo de recontextualização oficial (CRO), e o campo de recontextualização pedagógica (CRP). Considerando as possibilidades de relações propostas pelo modelo, vale ressaltar que estes campos são influenciados pelos campos da economia e do controle simbólico.

O CRO é criado e dominado pelo Estado e seus agentes, pelos departamentos especializados. Já o $C R P$ é composto pelos pedagogos e outros formadores de professores e pesquisadores das escolas, pelas faculdades e seus departamentos de educação, com suas pesquisas. Constituem também o CRP as fundações privadas, os "meios especializados de educação, jornais semanais, revistas, e as editoras, juntamente com seus avaliadores e consultores" e pode se estender "para campos não especializados do discurso educacional".

Os campos recontextaulizadores oficial (CRO) e pedagógico (CRP) têm por função criar, manter, mudar e legitimar o discurso, a transmissão e as práticas que regulam o discurso pedagógico. Estes campos definem portanto, o "que" categorias, conteúdos e relações a serem transmitidas e o "como" - modo de transmissão do discurso pedagógico.

Gerados a partir dos processos de recontextualização, encontram-se $o$ discurso pedagógico oficial (DPO) e o discurso pedagógico de reprodução (DPR). 0 DPO possui as regras oficiais que atuam na regulação da produção, reprodução, distribuição e mudanças nos textos pedagógicos, regulam também as práticas e a organização de seus contextos. Já o discurso pedagógico de reprodução (DPR) está inserido no nível da transmissão, aqui o código é o princípio que regula a relação entre transmissores e aquisidores, em contextos e espaços especializados.

De acordo com o modelo, no contexto de reprodução, o discurso pedagógico pode ser definido pela relação entre discurso instrucional (conhecimentos e competências) e DR que corresponde ao discurso regulador, relacionado com a aquisição de valores, normas de conduta social e competências sócio-afetivas.

Quando os discursos pedagógicos produzidos ao nível dos campos de recontextualização oficial e pedagógica são inseridos no nível de transmissão, eles podem sofrer ainda um processo de recontextualização, que depende do 
contexto específico e da prática pedagógica. Com isso, o discurso reproduzido é influenciado pelas relações que caracterizam os contextos específicos da sua transmissão. Também pode ser influenciado pelas relações que se estabelecem entre os contextos específicos de educação e a comunidade.

De acordo com Morais e Neves (2007b), a forma de especialização da comunicação educacional é regulada pelo código pedagógico, o que significa que o discurso pedagógico contem uma mensagem sociológica. 0 código pedagógico pode dar origem a diversas formas de discurso pedagógico e portanto, de diversas mensagens, dependendo da distribuição de poder e dos princípios de controle.

Vale ressaltar que Bernstein (1996), considera que a prática pedagógica não necessariamente reproduz o discurso pedagógico, tampouco o que é adquirido é prioritariamente o que foi transmitido. As relações de poder que constituem, legitimam e mantem a classificação (distanciamento entre categorias, seleção de conteúdos e práticas) e o enquadramento (controle das formas de transmissão e de quem pode transmitir) do dispositivo, são produtos e produtoras de contradições e rupturas. Assim, apesar do dispositivo reproduzir a distinção entre o impensável e o pensável, não cria tais distinções, regula a relação entre distribuição de poder, de conhecimento e de formas de consciência.

Na obra Pedagogy, Symbolic control and Identity (BERSNTEIN, 2000) o autor propõem um modelo de síntese que reúne a relação entre as regras formais do dispositivo e a estrutura sociológica, práticas e processos originados por elas (figura 1.2). Nessa síntese é possível notar que as regras distributivas, recontextualizadores e avaliativas, atuam na regulação as relações entre poder, conhecimento e consciência. Do ponto de vista da realização do modelo, é possível notar como tais regras se relacionam aos campos de produção, recontextualização e reprodução dos discursos pedagógicos, conforme apresentamos anteriormente. 


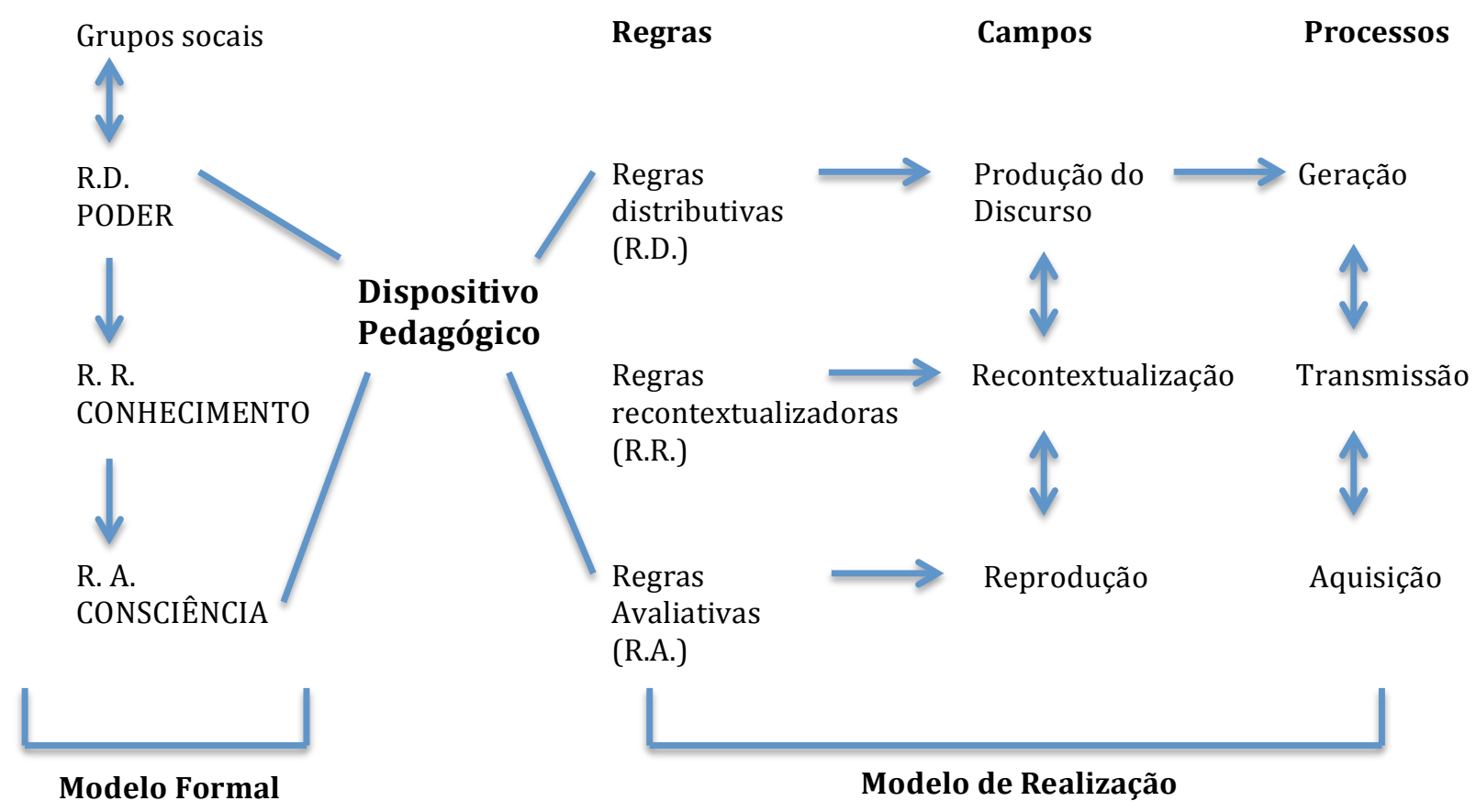

Figura 1.2: 0 dispositivo e suas estruturas, adaptado de Bernstein (2000).

Em resumo, Bernstein (1996) aponta que procurou construir um modelo descritivo dos processos relacionados ao discurso e à prática pedagógica. Esse modelo, de acordo com o autor: "torna possível, através da regulação e distribuição dos conhecimentos e dos discursos que esses conhecimentos pressupõem, a transformação do poder (isto é, sua base nas relações sociais e em seus locais generativos) em consciências diferentemente especializadas (sujeitos). Neste sentido, o dispositivo pedagógico é a condição para a cultura (suas produções, reproduções e modalidades de suas inter-relações)" (p.293).

\subsubsection{Discursos verticais e horizontais}

Em um dos seus últimos trabalhos, Bernstein (1999), distingui as formas dos discursos, isto é, os princípios internos da construção dos discursos que são sujeitos a recontextualização pedagógica e de suas bases sociais.

Bernstein parte da distinção entre discurso 'horizontal' e discurso 'vertical'. Como critérios para essa distinção Bernstein considera, as diferentes 'formas de conhecimento' que são realizadas nos dois discursos. 0 discurso horizontal corresponde a uma forma de conhecimento que tem como característica ser organizado de forma dividida. Este tipo de discurso 
corresponde ao conhecimento do dia-a-dia ou do senso comum, é dependente e específico do contexto.

Já o discurso vertical possui uma estrutura coerente e pode ter organização hierárquica, como no caso das ciências naturais; ou a forma de uma série de linguagens especializadas, como os discursos da área de humanas. A distinção entre estes discursos é referida em contextos educacionais à diferenciação entre os discursos acadêmicos e não acadêmicos.

De acordo com Bernstein (op. cit.) o caráter distinto dos discursos horizontal e vertical faz com que a forma em que são utilizados pela pedagogia e modo de sua aquisição, tenham características diferentes.

Aquilo o que é adquirido e a forma de aquisição relativos aos discursos horizontais, podem ser marcadamente distintos por conta dos contextos específicos. Os conhecimentos desse discurso são relacionados, não pela integração de seus significados, mas sim pelas relações entre as funções que possuem na vida cotidiana. Em geral, os conhecimentos do discurso horizontal são adquiridos na forma de competências comuns.

Já no discurso vertical, os conhecimentos são integrados ao nível dos significados e não dos contextos, como no discurso horizontal, a integração ocorre hierarquicamente entre esses significados. De acordo com Morais e colaboradoras (2014), "enquanto no discurso horizontal existe especificidade contextual através da 'segmentação', no discurso vertical existe especificidade contextual através da 'recontextualização'”' (p. 34).

Bernstein (1999) distingue ainda dois tipos de discurso interior ao discurso vertical de acordo com a estrutura que se organizam os conhecimentos: discurso vertical de estrutura horizontal e discurso vertical de estrutura vertical. As ciências sociais e humanidades, como é o caso da educação, têm uma estrutura de conhecimento fundamentalmente horizontal, caracterizada por linguagens paralelas e com formas especializadas de questionamento e com critérios especializados para a produção e circulação de textos. Outra característica dessas estruturas horizontais de conhecimento é a existência de uma acumulação de linguagens, em oposição as estruturas verticais em que há uma integração da linguagem. Os conhecimentos das áreas de ciências naturais e exatas caracterizam-se por integrar proposições e teorias que operam a níveis 
cada vez mais abstratos, buscando explicações mais uniformes para fenômenos relativamente diferentes.

Morais (2004), utilizando a Biologia como exemplo de estrutura hierárquica, aponta que uma teoria como a evolução ou a teoria celular possuem contém códigos integradores que unificam ideias relacionadas com um conjunto de fenômenos. 0 desenvolvimento de teorias complexas e temas transversais resulta de um processo de produção de conhecimentos cada vez mais abrangentes, que se valem outros conceitos e teorias anteriores sobre os mesmos fenômenos.

Ao tomar a Sociologia como um exemplo de conhecimento de estrutura horizontal, Morais (op. cit.) propõe que o funcionalismo, o pós-estruturalismo, o pós-modernismo, dentre outros, correspondem a linguagens diferentes dentro desta área do conhecimento. Nas estruturas horizontais o desenvolvimento de conhecimentos levará à introdução de uma nova linguagem, com um novo conjunto de questões, de relações e, aparentemente, com uma nova problemática.

Bernstein (1999) diferencia ainda conhecimentos de estruturas horizontais quanto a linguagem interna de descrição. Discursos horizontais com gramáticas fortes, por exemplo a economia, matemática e linguística, podem gerar descrições empíricas relativamente precisas. Aquelas que possuem uma linguagem interna de descrição com gramáticas fracas, como a sociologia e antropologia, podem ser são geralmente, incapaz de gerar descrições empíricas precisas e sem ambiguidades.

Ao definir a forma dos discursos verticais de estrutura horizontal e vertical, Bernstein procura evidenciar os princípios internos da construção de conhecimento acadêmico em áreas distintas e que estão sujeitos à recontextualização pedagógica. De acordo com o autor ao conhecer as diferenças entre as estruturas do conhecimento é possível compreender aspectos sobre os problemas de aquisição destes.

\subsection{O uso da teoria de Bernstein em diferentes contextos}

Como dito anteriormente, as pesquisas que utilizam os trabalhos de Bernstein tem aumentado significativamente nas últimas décadas. Diferentes 
conceitos e aspectos da teoria de Bernstein têm sido abordados nestas pesquisas, tais como: pedagogias visíveis e invisíveis, modelo pedagógico de competência e de desempenho, currículo de coleção e de integração, código restrito e código elaborado, discurso vertical e discurso horizontal, autonomia relativa da educação, recontextualização e reprodução do discurso pedagógico, educação e classe social, entre outros (MAINARDES e STREMEL, 2010).

De acordo com os autores, o modelo do discurso pedagógico tem sido utilizado em pesquisas sobre políticas educacionais e políticas curriculares. Esses trabalhos têm explorado o conceito de recontextualização do discurso das políticas educacionais, discutindo aspectos do discurso oficial, do discurso pedagógico e do campo recontextualizador local (família e comunidade).

Mainardes (2004), analisou a emergência e desenvolvimento do discurso da política de organização da educação em ciclos no Brasil. 0 autor mostrou que as atuais políticas de ciclos têm uma série de características das pedagogias invisíveis. De acordo com a pesquisa, essas políticas tornam-se complexas pois representam uma mudança de código, uma transição da pedagogia visível para uma pedagogia invisível.

Ainda em relação às investigações de políticas educacionais que utilizam os conceitos de Bernstein, Sadovnik (2006) traz uma análise do Programa No child left behind (NCLB) desenvolvido pelo governo dos Estados Unidos da América. Para o autor, o NCLB ampliou o poder do campo recontextualizador na esfera federal e enfraqueceu a relativa autonomia dos estados e das autoridades locais de educação. Apesar de se basear na igualdade de acesso e ter como intenção diminuir a diferença existente no desempenho dos alunos de diferentes classes sociais, o programa não desenvolveu ações voltadas para mudanças nas práticas pedagógicas, que ao longo da história mantem as diferenças de desempenho. Assim, para Sadovinik (op. cit.) o programa, sob uma chancela aparentemente inovadora, acaba por reproduzir as mesmas desigualdades.

Os conceitos da teoria de Bernstein e de contextualização foram utilizados na análise dos Parâmetros Curriculares Nacionais para o Ensino Médio (PCNEM) por Lopes e colaboradoras (2013). As autoras apontam a necessidade de questionamento sobre esses textos oficiais, pois a proposta curricular limita as possibilidades de mudança para a superação do conhecimento hegemônico e do 
conhecimento para a atuação no mercado de trabalho.

Diversos trabalhos sobre o processo de recontextualização em currículos de ciências, mostram que a mensagem dos currículos analisados, quanto a diversas características, traduz um discurso oficial conceitualmente pobre. Como os professores tendem a recorrer aos documentos curriculares é possível pensar que os alunos terão acesso a uma educação científica conceitualmente pouco exigente (FERREIRA, MORAIS e NEVES, 2011; FERREIRA e MORAIS, 2013; CALADO, MORAIS e NEVES, 2013; SILVA, MORAIS e NEVES, 2013b). No entanto, como destacam as pesquisadoras, dependendo da formação científica e pedagógica dos professores, a recontextualização da mensagem do currículo nas suas práticas pode levar a aprendizagens mais exigentes conceitualmente.

Essa pesquisas trazem também como conclusão, o questionamento sobre a legitimidade do currículo em relação aos princípios dominantes da sociedade, no que se refere à igualdade de acesso e sucesso dos alunos. Isso decorre do fato do currículo apresentar baixo nível de exigência conceitual, associado a princípios ideológicos e pedagógicos de seus conceptores que não são favoráveis à aprendizagem científica de todos os alunos.

Pesquisas que analisam os processos de recontextualização entre currículos, materiais pedagógicos e práticas pedagógicas, bem como aprendizagem dos alunos, têm sido realizadas por diversas autoras (GALIAN, 2011; CALADO e NEVES, 2012; ALVES e MORAIS, 2013; SILVA, MORAIS e NEVES, 2013a; FERREIRA e MORAIS, 2013). Estes trabalhos evidenciam que o nível de exigência da educação científica diminui ao longo do sistema educativo. Essa diminuição foi percebida por meio de processos de recontextualização que ocorreram, dentro do campo oficial; entre currículos e exames; entre currículos e materiais pedagógicos; e ainda entre currículo, materiais e práticas pedagógicas. Com isso, como apontam as pesquisas, o nível de proficiência científica que os alunos poderão atingir será baixo, colocando em destaque mais uma vez, a importância da formação e ideologia dos professores para o aumento de do nível de exigência conceitual.

No que se refere as práticas pedagógicas, as pesquisas acima apresentadas e outras desenvolvidas pelo grupo ESSA, apontam que uma prática altamente favorável à aprendizagem das crianças de origens sociais diferentes 
deve mesclar características como: fortes relações intradisciplinares; alto nível de exigência conceitual e alto nível de proficiência investigativa; seleção e sequência de conhecimentos, competências e atividades controladas pelo professor; relações dialógicas na comunicação entre professor-alunos e alunosalunos; critérios de avaliação explícitos; algum grau de controle do aluno sobre o tempo de aquisição.

Kress e colaboradores (2000), analisaram a representação de paisagens por crianças sob a perspectiva das novas teorias da semiótica, utilizando o modelo do discurso pedagógico. Os autores concluíram que essas novas abordagens, fazem com que as fronteiras entre linguagem e o visual sejam mais fracas. Entram em cena outros discursos, que além de suas características instrucionais, trazem discursos reguladores próprios. Com isso, fortes relações intradisciplinares possibilitam espaços para a mudança nas mensagens associadas aos discursos das artes.

Damiani (2006) buscou identificar os fatores de risco para o fracasso escolar (repetência e/ou evasão). Para isso, com base no conceito de dispositivo pedagógico, utilizou um modelo que examinou o risco de fracasso associado a diferentes variáveis pessoais e familiares. Os resultados indicam a importante influência dos fatores relacionados à classe social em que os sujeitos estão posicionados. A pesquisa comparou também, escolas que tem índices de fracasso escolar extremos, nesse caso, os resultados indicam que as instituições de ensino diferem entre si e apontam para a importância dos fatores do micro contexto. As escolas com menores taxas de evasão dão ênfase aos conhecimentos acadêmicos (discurso instrucional) de nível de exigência mais elevados.

0 trabalho de Smith (2013), procurou evidenciar as características dos modelos de pedagogia "visível" e "invisível" em escolas de ensino básico. Ao comparar a prática pedagógica e a interação professor-aluno em diferentes "modelos" de escolas, notou que aquela de pedagogia visível, possuía hierarquias fortes, objetivos e critérios de avaliação muito explícitos. Na escola de pedagogia invisível raramente ficou evidente para as crianças os objetivos dos professores e portanto, o texto legítimo.

Moss (2000) analisou a relação entre o conhecimento das crianças em contextos formais, em diferentes escolas, e em contextos informais. Baseando-se 
em conceitos de Bernstein sobre as formas do discurso - "discurso horizontal e vertical", o artigo argumenta que as crianças da classe média e crianças das classes trabalhadoras evoluem de forma semelhante quanto a competências globais no domínio informal, porém o mesmo não ocorre no contexto formal. Assim, a escolaridade posiciona esses sujeitos de forma diferenciada e possibilita "diferentes futuros" para as crianças da classe média e das classes trabalhadoras.

Nos contextos não-formais de educação, nomeadamente os museus, as pesquisas que utilizam os conceitos de Bernstein ainda são escassas. As que apontamos a seguir, utilizam o conceito de dispositivo pedagógico para a análise do processos de recontextualização dos discursos e análise das práticas museais.

A análise de como o público compreende temas científicos em exposições foi realizada por Botelho e Morais (2003), utilizando o modelo do discurso pedagógico proposta por Bernstein. De acordo com os autores, para que os objetivos pedagógicos presentes nas exposições sejam atingidos de maneira eficaz, é necessário que os visitantes reconheçam as especificidades do contexto museal. Esse reconhecimento é um primeiro passo para que a interação do público com os objetos e aparatos expositivos seja mais significativa. Além disso, o estudo apontou para a necessidade da investigação sobre as características sociológicas do contexto dos museus, permitindo apurar o modo como elas influenciam na compreensão dos fenômenos exemplificados e dos procedimentos e conceitos envolvidos.

A teoria de Basil Bernstein, mais especificamente o modelo do discurso pedagógico, foi utilizada por Marandino (2001) na análise dos discursos de cinco exposições. Derivados desse trabalho e aprofundando a utilização da teoria de Bernstein em contextos museais, Marandino (2014) publicou o artigo "The expositive discourse as pedagogical discourse: studying recontextualization in the production of a science museum exhibition" (0 discurso expositivo como discurso pedagógico: estudando a recontextualização em exposições de ciências ). De acordo com a autora, o contexto histórico e político e a divisão do trabalho nas instituições museais, influenciam o poder que diferentes agentes possuem na produção dos discursos expositivos. A pesquisa revela o papel dos vários profissionais envolvidos na produção das exposições, além dos especialistas, participam da definição do discurso expositivo, educadores e museólogos. Estes 
diferentes agentes podem ter maior ou menor poder de decisão em função da autonomia que a instituição propicia para a realização do trabalho.

Já Martins (2011) buscou contribuir para a definição das especificidades epistemológicas da educação museal, por meio da análise de práticas museais realizadas pelos setores educativos de diferentes tipologias de museus. A autora mostra que os educadores que atuam nos diferentes museus estudados, são os responsáveis tanto pela produção quanto pela recontextualização dos textos pedagógicos. Existe uma atuação concreta dos profissionais de educação na produção de conhecimento dentro do campo de recontextualização oficial, além de serem responsáveis pela recontextualização pedagógica desse conhecimento.

No presente trabalho buscamos analisar aspectos da produção e da reprodução do discurso expositivo, considerando-o como um discurso pedagógico. Para isso, será utilizado o modelo do discurso pedagógico proposto por Bernstein.

No que se refere ao contexto de produção esta investigação pretende identificar os campos recontextualizadores que influenciam diretamente no processo de construção do discurso expositivo, bem como, caracterizar os agentes e discursos do campo recontextualizador pedagógico.

Com foco nas questões sobre biodiversidade, a análise do discurso expositivo, compreenderá a sua caracterização quanto aos componentes instrucionais, o "que" do processo de transmissão-aquisição (conceitos e competências), e quanto às relações entre os discursos, o "como" do processo de transmissão-aquisição (relações entre e dentro das áreas de conhecimento e entre a natureza e seres humanos). A partir dessa análise buscaremos refletir sobre a complexidade dos conteúdos sobre biodiversidade tratados na exposição.

A análise do discurso expositivo deve também relacionar as características do discurso instrucional às intenções e objetivos dos conceptores da exposição e das agências envolvidas, buscando compreender aspectos do processo de recontextualização. 


\section{Capítulo 2 - Aspectos metodológicos: relações entre teoria e métodos}

\subsection{Aspectos gerais}

Este trabalho foi orientado por uma metodologia mista, conciliando abordagens de cunho qualitativo e quantitativo. A proposta metodológica que foi utilizada como base tem sido largamente utilizada nos trabalhos do grupo de pesquisa Estudos Sociológicos da Sala de Aula (ESSA). O principal aspecto desta proposta é conciliar as duas abordagens - quantitativa e qualitativa, utilizadas sequencial ou simultaneamente (MORAIS e NEVES, 2001, 2007a e 2009).

Considerando que o foco deste trabalho é a análise da produção e das características dos discursos expositivos, com embasamento da teoria sociológica de Basil Bernstein e das referências da educação em museus, entendemos que a metodologia mista ou quali-quanti é a que melhor se adequa para responder às questões desta investigação. Isso se deve ao fato desse tipo de metodologia contribuir, por um lado, para a análise em profundidade dos processos sociais, proporcionada pelas metodologias qualitativas, e por outro lado, trazer robustez e um caráter menos indutivista à investigação sobre as características dos discursos por meio da contribuição da metodologia quantitativa.

De acordo com Teddle e Tashakkori (2009), o uso de metodologias mistas tem se tornado mais popular em pesquisas nas ciências sociais. Segundo os autores, essas abordagens podem ser utilizadas para a coleta de dados e análise, proporcionando a integração de dados e inferências. Além disso, as metodologias mistas podem responder a questões sob um maior número de perspectivas, sendo extremamente útil quando uma metodologia não fornece todas as informações necessárias para atingir os objetivos da pesquisa.

Há diferentes tipos de pesquisas de metodologia mista. Nos trabalhos de Creswell (2007) e Creswell e Plano Clark (2007) os autores definem três designs básicos de pesquisas mistas. Elas podem ser paralelas convergentes, em que há coletas qualitativas e quantitativas que convergem na análise, e as de conduta sequencial explicativa e exploratória (quanti-quali ou quali-quanti). 
Para Johnson e Onwuegbuzie (2004), a maioria dos projetos de pesquisas com metodologias mistas pode ser desenvolvida a partir de dois tipos de designs principais, que incluem o modelo misto, em que há uma mistura de abordagens qualitativas e quantitativas dentro ou entre as etapas do processo de pesquisa; e o método misto, no qual há a inclusão de uma fase quantitativa e uma fase qualitativa. É fundamental ainda considerar a dimensão da ênfase paradigmática e da ordenação temporal das fases qualitativa e quantitativa (sequencial ou simultânea). Esses autores propõem que uma forma de se visualizar os métodos mistos de pesquisa é considerar o grau de mistura, que formaria um contínuo de método único para métodos totalmente misturados.

De acordo com Morais e colaboradoras (2014), a utilização de quadros teóricos de referência para a construção dos instrumentos de análise de dados, conferem à metodologia um caráter mais racionalista, característico de abordagens quantitativas. Já a construção de indicadores e categorias com base em documentos e observações, assim como a natureza contextual dos objetos de estudo, são de natureza naturalística, característica das abordagens qualitativas.

Este trabalho possui um caráter racionalista pois utilizou uma perspectiva teórica norteadora, a Teoria do Discurso Pedagógico de Basil Bernstein, que orientou a investigação e o desenvolvimento dos instrumentos de coleta e análise dos dados. Representam também características quantitativas a seleção de um número significativo de unidades de análise (trechos de textos, com imagens e objetos relacionados) e a quantificação delas de acordo com os diferentes instrumentos. Contudo, a abordagem qualitativa também está presente nesta pesquisa uma vez que foram adaptados ou construídos indicadores e categorias com base nos dados empíricos. Além disso, o discurso expositivo é um objeto de estudo contextual e o universo bastante específico exposições de imersão sobre biomas em dois jardins botânicos.

Vale ressaltar que a seleção desta metodologia proporciona uma relação dialética entre a teoria norteadora da pesquisa e os dados analisados. De acordo com Bernstein (2000), a metodologia sociológica de investigação deve possuir uma linguagem de descrição que permita a tradução de uma linguagem interna em externa e vice-versa. Para o autor a linguagem interna de descrição está relacionada às teorias e conceitos, e há uma linguagem externa que corresponde 
à interface que permite o diálogo entre os dados empíricos e a linguagem interna. Nesse modelo, uma linguagem pode se traduzir na outra, nos dois sentidos, em uma relação dialética. Conforme Morais e Neves (2003), por meio desta relação dialética, a teoria, a linguagem de descrição e a análise empírica interagem, transformando-se de forma recíproca. Assim, a compreensão da realidade que se pretende estudar pode ser mais precisa e profunda. 0 desenvolvimento dos instrumentos de análise utilizados neste trabalho decorre de uma articulação entre a teoria e a dimensão empírica. Com isso, as análises tiveram a intenção de possuir caráter menos subjetivo e menos indutivista.

\subsection{Instrumentos de coleta e análise dos dados}

Os discursos expositivos e seus processos de produção analisados neste trabalho referem-se às exposições permanentes "Estufa do Cerrado", sediada no Jardim Botânico de São Paulo, e "Estufa da Caatinga Mineira", sediada na Fundação Zoo-botânica de Belo Horizonte.

Localizada no Jardim Botânico de São Paulo, a exposição de longa duração "Estufa do Cerrado" ocupa uma das duas estufas concebidas por Carlos Heine na criação desse jardim. Atualmente o Jardim Botânico é um departamento do Instituto de Botânica da Secretaria de Meio Ambiente do Estado de São Paulo. A iniciativa da produção da exposição Cerrado partiu de pesquisadores da área de biologia, especialistas nesse bioma. Contando com verba de compensação ambiental de uma obra viária e contrapartida da instituição sede (Instituto de Botânica), foi realizada a exposição.

A exposição de longa duração "Estufa da Caatinga Mineira" está sediada na Fundação Zoo-botânica de Belo Horizonte (FZB-BH), na área do jardim Botânico. A Fundação está vinculada à prefeitura da cidade de Belo Horizonte, tendo como parceiros a Sociedade dos Amigos da FZB-BH e os Parceiros da Natureza. A produção da exposição "Estufa da Caatinga Mineira" foi um dos produtos de um projeto vencedor do "Prêmio Projetos Educacionais Modelos nos Jardins Botânicos brasileiros", concedido pelo "Projeto Investindo na Natureza - 
Brasil”12, iniciativa do órgão internacional de jardins botânicos - Botanic Gardens Conservation International (BGCI) com apoio do banco HSBC.

Foram coletados dados de entrevista, observação e documentos de ambas as exposições. As observações foram realizadas de acordo com roteiro (anexo 5.1) e os documentos são compostos pelos textos finais dos painéis, placas, etiquetas e a planta baixa, fornecidos pelos conceptores da exposições. Também foram realizadas entrevistas semiestruturadas aos conceptores e/ou responsáveis pelas mesmas, desenvolvidas de acordo com roteiro previamente elaborado (anexo 5.2), gravadas em áudio e posteriormente transcritas.

Foram entrevistados quatro conceptores que participaram do desenvolvimento da exposição "Estufa do Cerrado" e cinco da "Estufa da Caatinga Mineira". As entrevistas da exposição sobre o Cerrado foram realizadas em 2014 e 2015, incluindo três conceptores de conteúdo científico (CER1, CER2, CER3) e um de expografia (CER4). CER1 é bióloga e à época da concepção da exposição era pesquisadora científica nível 6 do Instituto de Botânica da Secretaria de Estado do Meio ambiente. Já CER2, tinha formação em História Natural e estava aposentado do Instituto de Biociências, no qual foi docente e pesquisador do Departamento de Ecologia. A entrevistada CER3 foi contratada por uma organização social que atuou no desenvolvimento da expografia e na produção da exposição. Essa conceptora tem formação na área de biologia e realizou seu mestrado em Ecologia do Cerrado. CER4 é cenógrafa com ampla experiência em desenvolvimento e produção de exposições, tendo sida também contratada pela organização social responsável pela expografia e produção da "Estufa do Cerrado".

Os entrevistados que participaram do processo de produção da exposição sobre a Caatinga incluem quatro conceptores de conteúdo científico (CAA1, CAA2, CAA3, CAA4) e um responsável pela expografia (CAA5). As entrevistas, neste caso, foram realizadas em 2014. Os cinco entrevistados têm formação inicial em biologia e são funcionários concursados da Fundação Zoo-botânica de Belo Horizonte. CAA1, CAA2 e CAA4 são pesquisadoras do Jardim Botânico,

\footnotetext{
${ }^{12}$ Mais detalhes sobre o projeto podem ser encontrados em <https://www.bgci.org/worldwide/1823/>.
} 
departamento da fundação. A entrevistada CAA3 é coordenadora do Setor de Educação Ambiental da FZB-BH e CAA5 atua no Jardim Zoológico da fundação.

0 processo de produção do discurso foi analisado por meio de triangulações dos dados de entrevistas, documentos e observações. Para identificar as agências e agentes e descrever os campos recontextualizadores, de acordo com o modelo do discurso pedagógico de Basil Bernstein, foram utilizados os documentos fornecidos pelos conceptores das exposições e as entrevistas realizadas junto a eles. Foram também consultados sites de agências oficiais e organizações citadas nas entrevistas e referidas nos documentos e textos das exposições.

Em busca da delimitação do campo de recontextualização oficial dos museus, levando em consideração as especificidades e tipo de vinculação dos jardins botânicos às agências de estado, realizamos um levantamento da bibliografia pertinente, entre as quais buscamos identificar nos "textos oficiais", as principais politicas públicas para a educação nesses espaços. No que concerne às temáticas específicas das exposições - biodiversidade e biomas, buscamos identificar materiais e publicações desenvolvidos pelas agências governamentais em âmbito federal.

Para a análise do o "que" e do "como" do discurso expositivo, foram definidas unidades que correspondem a trechos de textos, objetos e imagens inter-relacionados, conforme mostra a figura 2.1. A seleção delas foi feita com base na presença de conteúdos relacionados à biodiversidade, levando em conta a definição ampla deste termo, conforme apresentamos na introdução. As unidades foram agrupados em módulos expositivos, definidos por nós, utilizando como critério os subtemas explicitados em documentos e observação das exposições. 


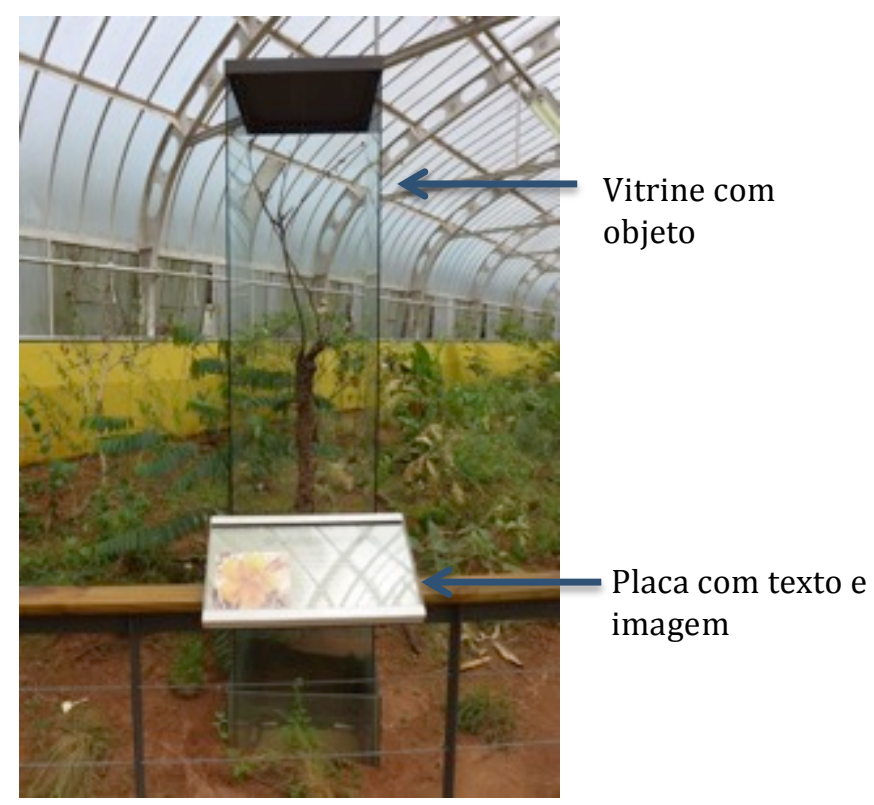

Figura 2.1: Exemplo de unidade de análise contendo objeto, texto e imagem.

A análise do "que" do discurso expositivo, contou com a utilização de dois instrumentos, um destinado à caracterização da complexidade dos conhecimentos científicos (1) e outro das competências cognitivas (2). Na discussão, relacionamos as características do "que" do discurso, obtidas na análise, com os objetivos e ideais dos conceptores, obtidos por meio das entrevistas.

A figura 2.2 resume as características do "que" do discurso expositivo analisadas nesse trabalho.

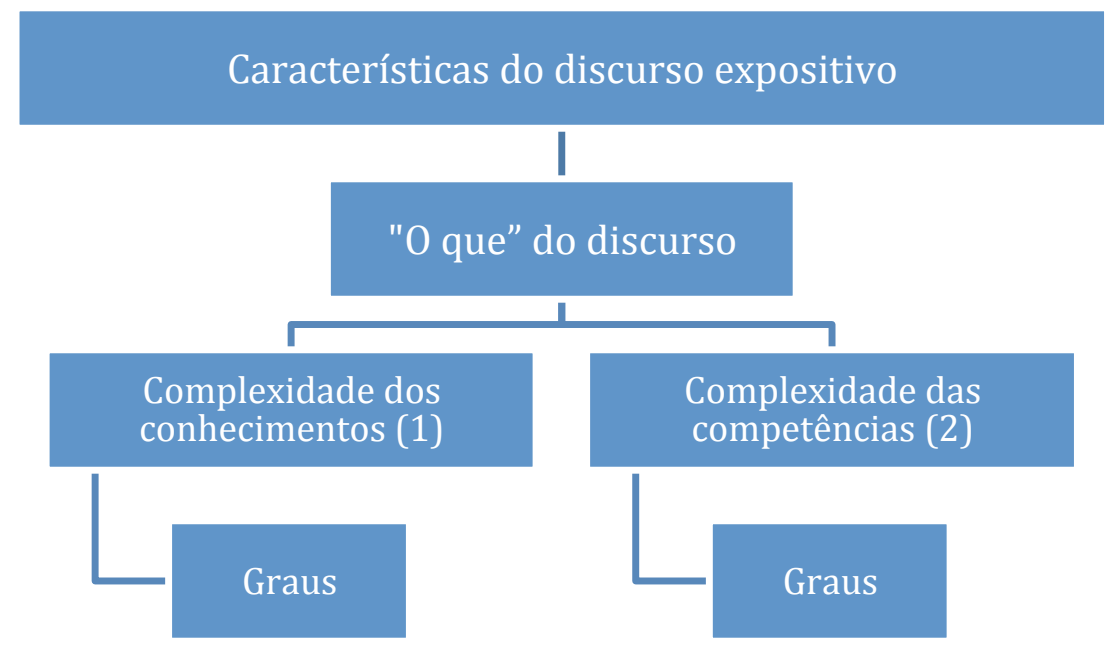

Figura 2.2: Aspectos do o "que" do discurso considerados para a análise 
Em um nível mais abrangente, para a compreensão do "como" do discurso expositivo, realizamos a análise das relações entre os módulos no que diz respeito aos conteúdos abordados. Para isso, identificamos nas unidades de análise de cada módulo, a presença dos conteúdos centrais - subtemas dos demais módulos.

Em um nível mais específico, a análise do "como" do discurso expositivo foi realizada por meio de três instrumentos. 0 primeiro deles é destinado à caracterização da interdisciplinaridade (3), ou seja, das relações entre os saberes e/ou áreas de conhecimentos. O segundo instrumento tem como objetivo a análise das relações entre os componentes da biodiversidade intradisciplinaridade (4), considerando a definição do termo pelas ciências biológicas. Já a análise das características do discurso expositivo quanto às relações entre humanos e natureza e conservação da biodiversidade (5) foi realizada por meio do terceiro instrumento.

A figura 2.3 resume as características do "como" do discurso expositivo analisadas nesse trabalho.

\section{Características do discurso expositivo - relações entre discursos}

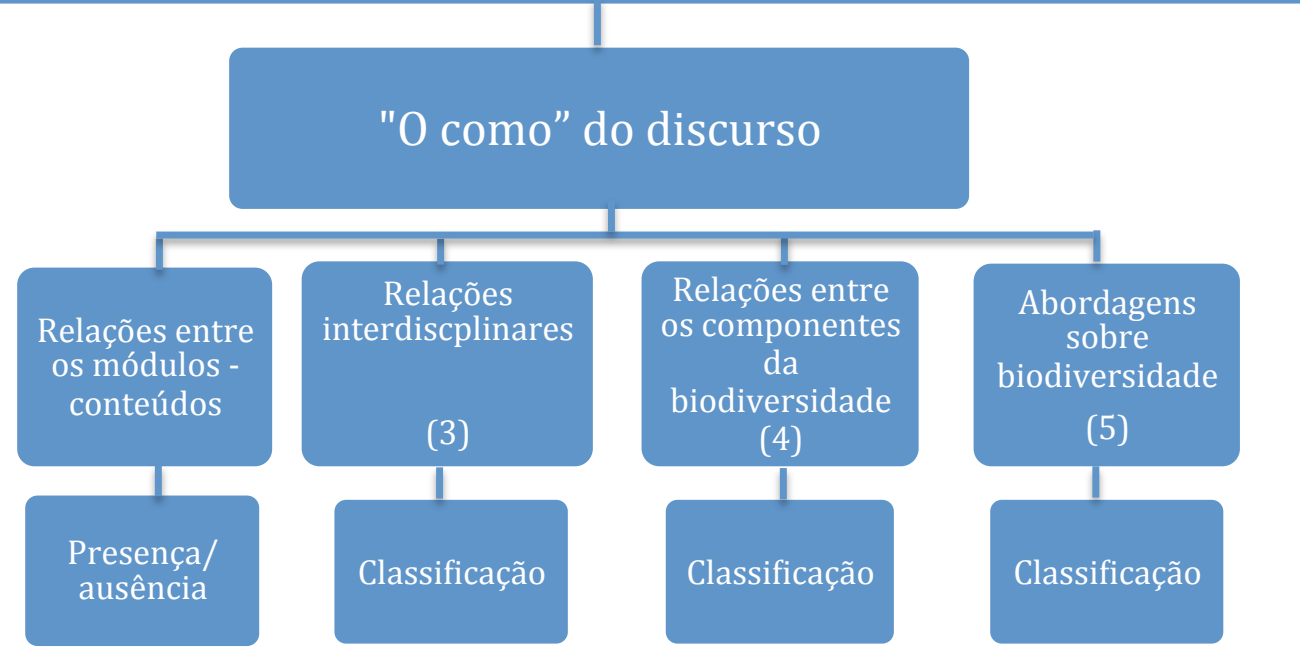

Figura 2.3: Aspectos do "como" do discurso considerados para a análise 


\subsubsection{Concepção e aplicação dos instrumentos para análise do "que" e "como" dos discursos}

Os instrumentos de análise foram construídos com base naqueles utilizados nas pesquisas do grupo ESSA. A etapa inicial de desenvolvimento dos instrumentos foi realizada sob supervisão das coordenadoras desse grupo de pesquisa, professora Dra. Isabel Maria Correia Pestana Ferreira das Neves e professora Dra. Ana Maria Morais, durante a realização de bolsa sanduiche de pesquisa no Instituto de Educação da Universidade de Lisboa/Portugal. Depois desta fase, os instrumentos foram readequados, no sentido de se adaptar às especificidades dos museus e dos conhecimentos sobre biodiversidade que serviram de base para a análise do nível de exigência dos conteúdos, que incluem os níveis de complexidade do "que" e do "como" do discurso. A ideia de nível de exigência dos conteúdos adotada neste trabalho tem como base o conceito de “Exigência Conceptual” proposto por Morais e Neves (2012), que será abordado em detalhes no capítulo 4.

Para aumentar a confiabilidade dos resultados, foi realizada a análise de uma amostra das unidades de análise junto aos pesquisadores do Grupo de Estudo e Pesquisa em Educação Não Formal e Divulgação em Ciência (GEENF).

Apresentamos a seguir cada um dos instrumentos utilizados na análise.

\section{Complexidade dos conhecimentos científicos}

Esse instrumento foi construído com base no trabalho de Ferreira e colaboradoras (2011). Para a adaptação do instrumento, no que se refere a descrição de cada grau de complexidade, utilizamos as definições de fatos (SAMPAIO e SOUZA et al., 2012) e as definições de conceitos concretos e abstratos propostos por Cantu e Herron (1978). Assim, foram definidos quatro graus de complexidade em uma escala que vai do nível mais baixo (grau 1) ao mais alto (grau 4), conforme o quadro 2.1. As unidades de análise foram categorizadas de acordo com o grau mais alto identificado, ainda que seja possível identificar na mesma unidade características com menor complexidade.

O grau 1 corresponde a fatos e exemplos. Segundo Sampaio e Souza e colaboradores (2012), os fatos estão na base do conhecimento conceitual e 
constituem uma parcela da informação sobre os objetos e eventos reais. Estão assim relacionados a dados concretos que resultam de repetidas observações.

O grau 2 corresponde a fatos relacionados e conceitos com baixo nível de abstração. Para Cantu e Herron (1978), esses conceitos, denominados por eles como concretos, possuem atributos (características e propriedades discrimináveis de um objeto ou evento) perceptíveis e exemplos observáveis, como o conceito de floresta.

Nos graus 3 e 4 encontram-se os conhecimentos com maior grau de complexidade. 0 grau 3 corresponde aos conceitos complexos, para os quais podem não existir exemplos observáveis e/ou atributos perceptíveis, como por exemplo o conceito de ecossistema. Em geral, exige um raciocínio hipotéticodependente sobre entidades invisíveis (CANTU E HERRON, op. cit.). Geralmente, os conceitos abstratos envolvem a compreensão de conceitos simples e fatos. 0 grau 4 inclui teorias e temas transversais. Os conhecimentos científicos, neste caso, possuem um nível mais alto de abstração, não existem exemplos perceptíveis ou atributos definidores, como por exemplo o próprio tema biodiversidade. Teorias e temas transversais incluem a relação de diversos conceitos de ordem simples e complexa.

Quadro 2.1: Contexto instrucional - 0 "que" do discurso. Complexidade dos conhecimentos científicos relacionados à biodiversidade.

\begin{tabular}{|c|c|c|c|c|}
\hline & Grau 1 & Grau 2 & Grau 3 & Grau 4 \\
\hline $\begin{array}{l}\text { Unidades } \\
\text { de análise }\end{array}$ & $\begin{array}{l}\text { Apresentam } \\
\text { conhecimento } \\
\text { científico de baixa } \\
\text { complexidade, } \\
\text { como fatos } \\
\text { isolados e } \\
\text { exemplos }\end{array}$ & $\begin{array}{l}\text { Inclui } \\
\text { conhecimentos } \\
\text { científicos como } \\
\text { fatos relacionados, } \\
\text { conceitos com } \\
\text { baixo nível de } \\
\text { abstração, } \\
\text { caracterização de } \\
\text { fenômenos. }\end{array}$ & $\begin{array}{l}\text { Inclui } \\
\text { conhecimentos } \\
\text { científicos como } \\
\text { conceitos } \\
\text { complexos, } \\
\text { relações entre } \\
\text { conceitos com } \\
\text { baixo nível de } \\
\text { abstração e/ou } \\
\text { destes com fatos. }\end{array}$ & $\begin{array}{l}\text { Inclui relação } \\
\text { entre } \\
\text { diferentes } \\
\text { conceitos } \\
\text { (baixo nível de } \\
\text { abstração e } \\
\text { complexos), } \\
\text { generalizações } \\
\text { que envolvem } \\
\text { teorias ou } \\
\text { temas } \\
\text { transversais. }\end{array}$ \\
\hline
\end{tabular}




\section{Grau de complexidade das competências cognitivas}

A complexidade das competências cognitivas foi analisada por meio de um instrumento construído com base nas taxonomias de Bloom (1986), Driscoll (2000), Krathwohl (2002), Marzano e Kendall (2007). Foram definidos quatro graus de complexidade conforme os diferentes processos cognitivos envolvidos, variando em uma escala que vai do nível mais baixo (grau 1) ao mais alto (grau 4), conforme o quadro 2.2. Adotamos o termo "competências cognitivas", sem contudo dar ênfase a um significado em particular ou buscar diferenciá-lo do termo "habilidades cognitivas", haja vista a falta de unanimidade em relação à definição precisa desses termos (ANTUNES, 2001; PRIMI et al., 2001). Vale destacar também que diferentes competências cognitivas podem estar presentes na mesma unidade de análise, assim optamos pela categorização de acordo com a presença da competência mais complexa.

No grau 1 de complexidade encontram-se as competências de "recuperação ou memorização do conhecimento" que envolvem a recordação e reconhecimento da informação. 0 grau 2 abrange as competências relacionadas à "compreensão do conhecimento", incluindo a construção de representações simbólicas e/ou integração das informações. O grau 3 esta associado às competências de "análise do conhecimento" que abarcam a generalização, classificação, comparação. Por fim, o grau 4 refere-se às competências de "utilização do conhecimento", tais como investigação, experimentação, resolução de problemas e tomada de decisão. 
Quadro 2.2: Contexto instrucional - 0 "que" do discurso. Complexidade das competências cognitivas relacionadas à biodiversidade

\begin{tabular}{|c|c|c|c|c|}
\hline & Grau 1 & Grau 2 & Grau 3 & Grau 4 \\
\hline $\begin{array}{l}\text { Unidades } \\
\text { de análise }\end{array}$ & $\begin{array}{l}\text { Competências de } \\
\text { "recuperação ou } \\
\text { memorização do } \\
\text { conhecimento"; } \\
\text { (exemplificar, } \\
\text { nomear, } \\
\text { reconhecer, } \\
\text { identificar, } \\
\text { descrever, } \\
\text { enumerar) }\end{array}$ & $\begin{array}{l}\text { Competências de } \\
\text { "compreensão do } \\
\text { conhecimento" } \\
\text { (retratar, ilustrar, } \\
\text { representar, } \\
\text { explicar, resumir, } \\
\text { descrição mais } \\
\text { complexa, usar } \\
\text { modelos) }\end{array}$ & $\begin{array}{l}\text { Competências de } \\
\text { "análise do } \\
\text { conhecimento" } \\
\text { (classificar, } \\
\text { comparar, } \\
\text { distinguir, criticar, } \\
\text { avaliar, concluir, } \\
\text { inferir) }\end{array}$ & $\begin{array}{l}\text { Competências de } \\
\text { "utilização do } \\
\text { conhecimento" } \\
\text { (decidir, } \\
\text { estabelecer } \\
\text { critérios, resolver } \\
\text { problemas, } \\
\text { investigar, } \\
\text { formular } \\
\text { hipóteses, } \\
\text { experimentar) }\end{array}$ \\
\hline
\end{tabular}

\section{Relações interdisciplinares}

Fronteiras entre as diferentes disciplinas que compõem um discurso pedagógico podem ser evidentes ou tênues a ponto de não notarmos a distinção ou posição delas no discurso. Segundo Bernstein (1996), se os discursos são especializados, cada qual possui uma identidade específica que só pode ser mantida e reproduzida caso as categorias sejam conservadas.

As relações entre os discursos das diferentes disciplinas esbatem estas fronteiras, aumentando a integração entre conteúdos, possibilitando a abordar conhecimentos de ordem mais complexa, com maior nível de abstração (MORAIS, 1991). Consideramos também que a análise da integração entre as disciplinas pode mostrar o quão especializadas são as vozes das diferentes áreas que compõem o discurso expositivo.

Vale ressaltar que na produção deste discurso podem atuar profissionais de várias áreas de conhecimento, e que o poder de cada uma dessas vozes vai definir o que será selecionado como conhecimento final a ser apresentado para o público (MARANDINO, 2014).

A análise das relações interdisciplinares teve como base o conceito de classificação proposto por Bernstein (1990). Quando não são estabelecidas relações entre as disciplinas (biologia, geologia, climatologia, museologia) e/ou áreas de constituição da exposição (ciências naturais, educação, expografia), 
considera-se que a classificação é forte. Já quando os assuntos possuem conexão ou mesmo não há fronteiras definidas entre eles, a classificação é considerada fraca ou muito fraca.

Foram estabelecidos três graus de classificação em uma escala de ampliação das relações entre os conhecimento, $C^{+}$(forte) a C-- (muito fraca). Para cada grau foi elaborado um descritivo conforme quadro 2.3 .

Quadro 2.3. Contexto instrucional - o "como" do discurso. Relação entre saberes e/ou conhecimentos de diferentes áreas.

\begin{tabular}{llll}
\hline & $\mathbf{C}^{+}$ & $\mathbf{C}^{-}$ & C-- $^{-}$ \\
\hline Unidades & $\begin{array}{l}\text { Só aparece uma área } \\
\text { específica de } \\
\text { de análise } \\
\text { feita referência a outros } \\
\text { saberes/conhecimentos } \\
\text { de outras áreas. Ou a } \\
\text { relação é feita de forma } \\
\text { genérica, ilustrativa. }\end{array}$ & $\begin{array}{l}\text { Estabelecem } \\
\text { referências e relações } \\
\text { entre } \\
\text { saberes/conhecimentos } \\
\text { de áreas } \\
\text { diferentes. No entanto } \\
\text { há uma ou mais área } \\
\text { com maior estatuto. }\end{array}$ & $\begin{array}{l}\text { Há integraçãos } \\
\text { diversos } \\
\text { saberes/conhecimentos, } \\
\text { não havendo hierarquia } \\
\text { ou diferença entre os } \\
\text { estatutos de cada uma. }\end{array}$ \\
\hline
\end{tabular}

\section{Relações entre componentes da biodiversidade (intradisciplinaridade)}

As relações entre os diferentes discursos serão analisadas com base em aspectos teóricos da teoria de Bernstein (1990), utilizando em especial o conceito de classificação. Os discursos ou áreas do conhecimento presentes no discursos expositivo foram considerados categorias. Quando não são estabelecidas relações entre elas, mais nítida é a separação entre essas categorias, logo considera-se que a classificação é forte. Já quando os discursos possuem conexão ou mesmo não há fronteiras definidas entre eles, a classificação é considerada fraca.

Diversos trabalhos consideram que a existência de relações entre os assuntos e conteúdos de uma área ou disciplina leva a níveis mais elevados de abstração e a uma visão mais integrada do conhecimento (FERREIRA, MORAIS e NEVES, 2011; GALIAN, 2011: CALADO, NEVES e MORAIS, 2013; FERREIRA e MORAIS, 2013). Bernstein (1999), propõe que o discurso das áreas de ciências naturais é um discurso vertical em que há uma estrutura hierárquica que integra 
diferentes conteúdos em direção a conhecimentos mais abstratos. Desse modo, quanto maior a integração entre conhecimentos, mais fraca é a classificação e mais chances de favorecer uma compreensão mais abstrata do conhecimento.

As definições de biodiversidade utilizadas no âmbito acadêmico e educacional podem incluir diferentes componentes em vários níveis de organização, conforme a figura 2.4. Esses componentes (composição, estrutura, função) podem ser considerados diferentes categorias ou discursos, que estão menos ou mais relacionados, e no todo condicionados por condições abióticas, que variam no tempo e no espaço. Consideramos que o estabelecimento de relações entre esses componentes pode levar a um nível mais abstrato e uma visão mais integrada de biodiversidade. Com base nisso, analisamos a presença de relações entre esses níveis, assumindo que ao relacionar um maior número de componentes da biodiversidade, há um aumento da complexidade em relação a definição deste tema. Procuramos também identificar quais desses componentes estão presentes e se estão em relação, buscando evidenciar as ausências, mas também aqueles que possuem "voz" mais presente no discurso expositivo sobre biodiversidade.

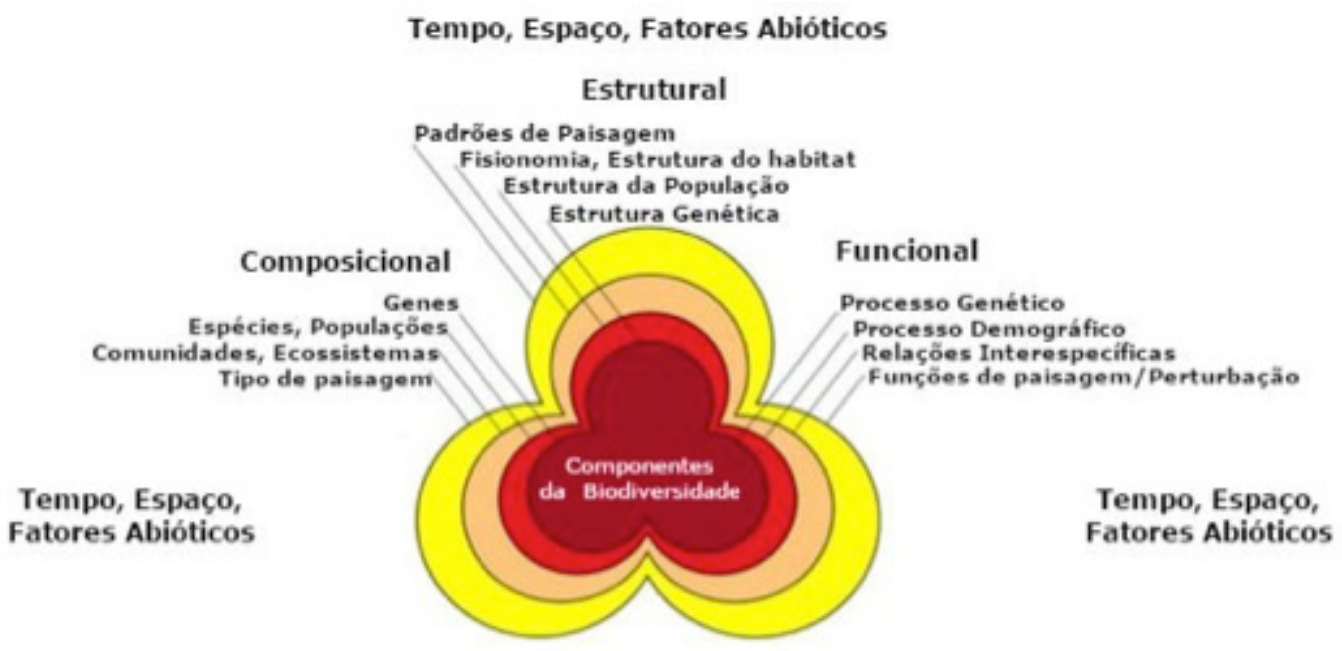

Figura 2.4: Componentes da biodiversidade, adaptado de Noss (1990)

Para analisar a relação entre os discursos sobre os componentes da biodiversidade, foram estabelecidos três graus de classificação em uma escala de ampliação das relações entre os componentes, que vai de $C^{+}$(classificação forte) 
a C-- (classificação muito fraca), quadro 2.4. Para estabelecer esses graus de classificação, tomou-se por referência os três níveis de organização ou componentes do conceito de biodiversidade - composicional, estrutural e funcional, e suas relações com fatores abióticos no tempo e espaço.

Quadro 2.4. Contexto instrucional - o "como" do discurso. Relação entre componentes da biodiversidade - intradisciplinaridade.

\begin{tabular}{|c|c|c|c|}
\hline & $\mathrm{C}^{+}$ & $\mathbf{C}^{-}$ & $\mathrm{C}^{--}$ \\
\hline $\begin{array}{l}\text { Unidades } \\
\text { de análise }\end{array}$ & $\begin{array}{l}\text { Inclui apenas um dos } \\
\text { componentes de } \\
\text { biodiversidade. Pode } \\
\text { incluir a relação entre } \\
\text { ele com fatores abióticos } \\
\text { no tempo e/ou espaço. }\end{array}$ & $\begin{array}{l}\text { Inclui relações entre dois } \\
\text { dos componentes de } \\
\text { biodiversidade. Pode } \\
\text { incluir a relação com } \\
\text { fatores abióticos no } \\
\text { tempo e/ou espaço. }\end{array}$ & $\begin{array}{l}\text { Relaciona os três } \\
\text { componentes de } \\
\text { biodiversidade. Pode } \\
\text { incluir a relação com } \\
\text { fatores abióticos no } \\
\text { tempo e/ou espaço. }\end{array}$ \\
\hline
\end{tabular}

\section{Relações entre os discursos - "natureza e humanos"}

Na sociedade atual há diferentes formas de abordar a biodiversidade. Essas formas de representação dependem do tratamento das questões ambientais em diferentes contextos históricos, sociais e políticos. Para caracterizar o discurso expositivo, considerando o papel educacional e comunicacional das exposições, quanto às formas de abordar, tratar ou representar a biodiversidade em diferentes contextos, foi construído um instrumento de análise (quadro 2.5) com base nas categorias de conservação propostas por Mace (2015), nas abordagens de biodiversidade utilizadas por Oliveira e Marandino (2012), e as representações sociais sobre biodiversidade propostas por Buijis e colaboradores (2008).

A classificação forte corresponde às representações da biodiversidade em que não há relações entre seres humanos e natureza, sendo aquele um observador dessa. Esse tipo de abordagem está associado à história natural e ecologia da vida silvestre, com descrições das espécies, das relações entre suas características e dessas com os ambientes em que vivem os organismos. As ações de conservação relacionadas a esse tipo de representação estão voltadas a criação de unidades de conservação com maior restrição de uso pelos seres humanos e outras ações pontuais. 
A classificação fraca abrange dois tipos de relações entre seres humanos e natureza: a "Natureza em oposição ao ser humano" e a "Natureza para as pessoas". Ainda que aparentemente antagônicas essas duas formas de representação da biodiversidade têm como mote os impactos negativos dos seres humanos sobre a natureza e os benefícios dela para nós. Essas duas "posições" aparecem muitas vezes ligadas, pontuando o benefício que pode ser perdido por causa da interferência excessiva dos humanos sobre a natureza. Esse tipo de abordagem pode incluir diferentes áreas de conhecimento, com ênfase nos aspectos funcionais da biodiversidade, serviços e valoração, gestão de recursos. As ações de conservação relacionadas a essa categoria de biodiversidade estão voltadas à preservação de espécies, mitigação de impactos, gestão sustentável dos recursos.

A representação de classificação mais fraca (fraquíssima) é a "Natureza com seres humanos". Nela, considera-se a multidimensionalidade e a dinâmica das relações entre nós e a natureza. Enfatiza a condição global do ser humano como parte da natureza. Inclui diversas áreas do conhecimento e da sociedade. As ações de conservação tendem a permear diversos âmbitos da sociedade, e são de bastante complexidade, uma vez que a variedade de dimensões e dos processos dinâmicos a serem considerados podem dificultar a integração dos conhecimentos científicos, saberes tradicionais, necessidades e interesses sociais.

Vale destacar as diferentes formas de representação social da biodiversidade podem conviver atualmente, assumindo a influência do contexto na legitimação e uso delas.

Quadro 2.5. Contexto instrucional - o "como" do discurso. Relação entre natureza e humanos

\begin{tabular}{llll}
\hline & $\mathbf{C}^{+}$ & $\mathbf{C}^{-}$ & \\
\hline $\begin{array}{l}\text { Unidades } \\
\text { de análise }\end{array}$ & $\begin{array}{l}\text { O ser humano é mero } \\
\text { observador, } \\
\text { expectador da } \\
\text { natureza. Enfatiza } \\
\text { atributos, descrição } \\
\text { da natureza. }\end{array}$ & $\begin{array}{l}\text { Enfatiza as relações } \\
\text { de oposição ou } \\
\text { benefícios entre } \\
\text { humanos e natureza. }\end{array}$ & $\begin{array}{l}\text { Enfatiza as } \\
\text { características } \\
\text { dinâmicas mútuas e } \\
\text { multidimensionais da } \\
\text { integração de } \\
\text { humanos e natureza } \\
\end{array}$ \\
\end{tabular}




\subsubsection{Tratamento dos dados}

Como foi dito, cada módulo é constituído por um conjunto de unidades de análise submetidas aos instrumentos construídos para caracterizar aspectos do o "que" e do "como" (grau de complexidade dos conhecimentos científicos e capacidades cognitivas, relações entre e dentro das áreas do conhecimento e relações entre ser humano e natureza). Assim, para cada módulo obteremos a frequência de unidades de cada grau ou classificação nos respectivos instrumentos.

Com base nessas frequências, efetuamos o cálculo do índice de complexidade ${ }^{13}$. Esse cálculo foi aplicado sobre os resultados de cada um dos instrumentos separadamente. 0 índice transforma os dados relacionados ao número de unidades de análise de cada grau de complexidade dos conhecimentos científicos e competências em valores numéricos, variando de 0 até 1 , sendo que valores mais altos correspondem a níveis mais elevados de "complexidade" que compõem discurso expositivo.

$\mathrm{Na}$ análise da complexidade dos conhecimentos científicos e competências cognitivas, o cálculo foi realizado sobre as porcentagens de cada grau de complexidade no conjunto das unidades de análise - índice total. Para entender como a complexidade varia ao longo da exposição, o mesmo cálculo foi efetuado para cada módulo das exposições. Assim, nos resultados são apresentados os índices de complexidade dos conhecimentos científicos e das competências cognitivas por módulo e no total.

Para os demais indicadores, referentes ao "como" do discurso expositivo, foram calculados apenas os índices totais, ou seja, o cálculo incidiu sobre a porcentagem de cada grau de classificação no conjunto das unidades de análise. Para os cálculos dos índices totais dos indicadores das relações entre discursos, as classificações fortes equivalem ao grau 1, as fracas ao grau 2 e muito fracas ao grau 3.

\footnotetext{
${ }^{13} \mathrm{O}$ cálculo do índice de complexidade dos conhecimentos e competências foi realizado com base em trabalhos anteriores do grupo ESSA. Na formula abaixo UA se refere às unidades de análise e G se refere ao grau de complexidade:
}

Complexidade dos conhecimentos: $\frac{(\text { no UAG } 1 \times 1)+(\text { no UAG } 2 \times 2)+(\text { no UAG } 3 \times 3)+(\text { no UAG } 4 \times 4)}{\text { no total UA } \mathrm{x} \text { Grau máximo }}$ 
Os índices totais de todos os indicadores, utilizados na análise do discurso expositivo da "Estufa do Cerrado" e "Estufa da Caatinga Mineira", foram comparados, no sentido de evidenciar como eles influenciam no nível de exigência dos conteúdos. 


\section{Capítulo 3 - O processo de construção do discurso: agentes, agências e campos}

Conforme apresentamos no capítulo 1, as teorias de currículo, que muitas vezes parecem estar voltadas apenas à educação formal, trazem reflexões muito mais amplas que dizem respeito às formas como a sociedade se relaciona com o conhecimento e legitima a produção, seleção e apropriação da cultura.

A complexidade da produção dos discursos e textos das exposições e outras atividades educacionais realizadas nos museus podem ser analisadas desde um ponto de vista das relações de poder, tal como é proposto por eixos de investigação das teorias críticas do currículo. Essa compreensão da educação museal traz à tona uma série de possibilidade analíticas.

Como foi dito anteriormente, utilizamos neste trabalho a teoria do discurso pedagógico proposta por Basil Bernstein, com enfoque na análise dos discursos e no processo de recontextualização. Consideramos para tal, que os discursos expositivos e aqueles presentes nas atividades educativas desenvolvidas pelas instituições museais analisadas são discursos pedagógicos construídos por meio de processos de recontextualização.

Vale lembrar que o dispositivo pedagógico é formado por um conjunto de regras que atuam sobre os significados que podem ser transmitidos pelas instituições de ensino e culturais. Há três conjuntos de regras que se interrelacionam: as distributivas que regulam as relações entre poder, grupos sociais e práticas; as recontextualizadoras que atuam na formação do discurso pedagógico; e as de avaliação que estabelecem critérios para a prática (BERNSTEIN, 1998).

O processo de construção do discurso pedagógico é regulado por regras recontextualizadoras, como afirma Leite (2007:32). Elas são o cerne do processo de recontextualização, o qual funciona a partir da apropriação de outros discursos, com a finalidade específica de atender ao processo de transmissão e aquisição de conhecimentos. De acordo com Mainardes e Stremel (2010), o discurso pedagógico é um princípio em que há a descontextualização de um discurso de sua prática e contexto originais e recolocação com base em princípios de focalização e reordenamentos seletivos de um novo contexto. 
No processo de recontextualização, no nível da geração do discurso, participam dois campos: o campo recontextualizador oficial (CRO) e o campo recontextualizador pedagógico (CRP) (BERNSTEIN, 1996, 1998; LEITE, 2007). A principal atividade destes campos é a definição do "que" - conceitos e competências, e do "como" - relações entre os discursos, relações entre os sujeitos e relações entre espaços, do discurso pedagógico. O CRO é criado e dominado pelo Estado e seus agentes, já o CRP é composto pelos pedagogos e outros formadores de professores e pesquisadores das escolas, pelas universidades e seus departamentos/faculdades de educação, e também as fundações privadas, os meios especializados de educação, jornais semanais, revistas, entre outros (BERNSTEIN, 1996).

Vale lembrar que segundo Bernstein (1996), o discurso pedagógico é definido pela relação entre o discurso regulador, que diz respeito a princípios e normas de conduta social (valores, atitudes) e o discurso instrucional, que diz respeito aos discursos específicos das disciplinas ou áreas de conhecimento (conhecimentos e competências). De acordo com o autor, há uma predominância do primeiro sobre o segundo, o que significa que há uma relocação do discurso instrucional em uma base reguladora, levando à transformação do discurso disciplinar específico ao longo do processo de recontextualização, por meio da atuação das agências e agentes recontextualizadores. Nesse sentido, é importante conhecermos quais são essas agências e agentes que atuam na recontextualização dos discursos pedagógicos dos museus.

Outro aspecto essencial na análise sociológica da educação em museus é que o processo de produção e reprodução do discurso pedagógico é extremamente dinâmico. Fontes potenciais de conflito, resistência e inércia estão presentes entre os agentes do CRO e do CRP e, ainda, no nível da transmissão (MORAIS, 2004). Pode existir assim, uma dinâmica entre posições, sujeitos e práticas dependendo da autonomia concedida a cada um desses elementos. 0 dinamismo é a característica que pode propiciar que mudanças nas estruturas de poder e controle tenham lugar.

Neste capítulo procuramos descrever os campos recontextualizadores, identificando os agentes e agências que participaram do processo de recontextualização dos discursos pedagógicos dos museus. Buscamos identificar 
também, as políticas e textos oficiais sobre biodiversidade, com ênfase nas concepções de educação presentes nesses documentos.

Assumindo que o discurso expositivo é uma modalidade de discurso pedagógico, descrevemos nesse capítulo os processos, agentes e agências que atuaram na produção dos discursos expositivos da "Estufa do Cerrado" do Jardim Botânico de São Paulo (JBSP) e "Estufa da Caatinga" da Fundação Zoo-botânica de Belo Horizonte (FZB-BH). Dentre os aspectos da descrição dos agentes envolvidos diretamente na concepção do discurso pedagógico, procuramos identificar as intenções e objetivos pretendidos na produção das exposições, além de como os agentes e/ou agências estão posicionados, ou seja, como estão distribuídos o poder e controle que influenciaram as escolhas e decisões tomadas na produção do discurso expositivo.

Vale destacar que o levantamento dos textos, agentes e agências que atuam nos campos recontextualizadores foi realizado levando em consideração que as instituições que sediam as exposições analisadas neste trabalho são jardins botânicos, e esses, por sua vez, são definidos como museus pelos órgão competentes em nível nacional e internacional, conforme aprofundaremos nos itens a seguir. Outro aspecto a ser ressaltado é que tal levantamento foi realizado também segundo o recorte temático desta pesquisa, isto é, os discursos relacionados à biodiversidade. Assim, para a análise do processo de produção das exposições "Estufa da Caatinga Mineira" e "Estufa do Cerrado", buscamos identificar nos itens 1.1 e 1.2 diferentes textos, agentes e agências que podem influenciar a produção dos discursos expositivos sobre biodiversidade em jardins botânicos. No item final desse capítulo, trazemos a descrição detalhada do processo de produção dos discursos expositivos presentes nas estufas, realizada por meio da análise das entrevistas, documentos e observações, relacionando tais processos aos textos e contextos recontextualizadores levantados nos itens anteriores.

\subsection{O Campo de Recontextualização Oficial dos museus}

De acordo com Bernstein (1996), o campo recontextualizador oficial (CRO) é responsável pela criação e manutenção do discurso pedagógico oficial, havendo 
nesse campo agências e agentes oficiais do Estado, indivíduos que fazem parte dos campos da economia e controle simbólico, além daqueles que atuam no sistema educacional. Como aponta o autor, pode haver nesse campo mais de uma agência ativa.

Na regulação dos textos e práticas da educação formal é possível perceber uma atuação mais centralizada do Ministério da Educação e órgão associados, além das secretarias estaduais e municipais de educação, contudo o mesmo não se aplica aos museus. Destacamos a seguir algumas considerações acerca da constituição do CRO dos museus que ajudam a compreender a diversidade desse campo e sua influência sobre a constituição do discurso pedagógico de reprodução.

Um primeiro ponto diz respeito à posição que a educação assume dentre as missões das diferentes instituições museais. Incorporado às definições de museu ${ }^{14}$ do comitê internacional (ICOM) e do Instituto Brasileiro de Museus (Ibram) do Ministério da Cultura (MinC), o papel educativo dos museus aparece dentre outras finalidades, tais como a preservação, pesquisa e extroversão relacionada ao patrimônio cultural e ambiental. Isso mostra, por um lado, o papel fundamental da educação nesses espaços, mas por outro lado, permite que essa função assuma posições de maior ou menor importância nas diferentes instituições museais.

No Brasil esse aspecto é reforçado pelas características do principal documento que define e estabelece as missões dos museus: o "Estatuto de Museus" do Ibram. O instituto constitui uma autarquia federal vinculada ao MinC, principal agência que regula a atuação cultural no país. Ainda que esteja presente na definição de museu do Ibram, o "Estatuto de Museus" aborda a educação em museus de forma bastante resumida, estabelecendo que os museus devem "promover ações educativas, fundamentadas no respeito à diversidade cultural e na participação comunitária, contribuindo para ampliar o acesso da sociedade às

\footnotetext{
${ }^{14}$ A definição de museu de acordo com o ICOM foi apresentada na introdução deste trabalho. Já no que se refere ao Ibram em 14 de janeiro de 2009 entrou em vigor no Brasil a Lei 11.904, que Institui o Estatuto de Museus e dá outras providências. De acordo com esse estatuto os museus são definidos como: As instituições sem fins lucrativos que conservam, investigam, comunicam, interpretam e expõem, para fins de preservação, estudo, pesquisa, educação, contemplação e turismo, conjuntos e coleções de valor histórico, artístico, científico, técnico ou de qualquer outra natureza cultural, abertas ao público, a serviço da sociedade e de seu desenvolvimento (BRASIL, 2009).
} 
manifestações culturais e ao patrimônio material e imaterial da Nação" (BRASIL, 2009, art. 29).

Outra consideração importante acerca da constituição do CRO dos museus e de sua influencia na construção do discurso pedagógico de reprodução, diz respeito a inexistência de uma demarcação legal que institua parâmetros para a adequação dos museus às suas finalidades. Como aponta Martins (2011), o "Estatuto de Museus" do Ibram parte de uma política de adesão por parte das instituições, não havendo assim uma obrigação dos museus a se ajustarem a determinados parâmetros de existência. Assim, o estatuto que poderia regular legalmente a atuação dos museus não têm correspondência de posição com, por exemplo, as diretrizes e bases da educação (LDB) e Parâmetros Curriculares Nacionais (PCNs).

Sobre a atuação do Ibram vale destacar, conforme Martins (op. cit.), que a criação dessa agência e de um instrumento de regulação é bastante recente no contexto da atuação do governo no âmbito da cultura. 0 órgão criado em 2009, ou seja, com menos de dez anos de atuação, foi responsável pela implementação da "Política Nacional de Museus" e pela melhoria dos serviços no setor que incluem a ampliação do número de visitantes, ações de integradas entre museus, políticas de aquisição e preservação de acervos, além da administração direta de 30 museus. Ainda de acordo com a autora, as transformações que levaram a criação do Ibram estão relacionadas ao crescimento e fortalecimento da área museal no Brasil e a expansão das atribuições do extinto Departamento de Museus (DEMU), órgão que estava vinculado ao Instituto de Patrimônio histórico e artístico nacional (Iphan). Esse quadro da recente emancipação da área com a criação do Ibram apoia a hipótese de que na década de 2000 esteve em curso o estabelecimento e fortalecimento de políticas públicas para museus.

Atualmente o Ibram é responsável pela Política Nacional de Museus (PNM), implementando-a por meio de diversas frentes de ação. 0 instituto desenvolveu e gere três importantes sistemas de coleta, integração e divulgação de informações. Um deles é o "Sistema Brasileiro de Museus (SBM)", que tem como finalidade de integrar a gestão e o desenvolvimento dos museus e instituições afins. 0 sistema visa também o desenvolvimento e integração de sistemas regionais, tanto estaduais quanto municipais, além de articular as redes 
temáticas de museus. Um segundo sistema é o "Cadastro Nacional de Museus (CNM)", que constitui uma plataforma colaborativa para o mapeamento de instituições e disponibilização de informações atualizadas sobre os museus do país. A partir dessa ação foram publicados em 2011 o "Guia dos Museus Brasileiros" e o "Museus em Números", sendo esse o primeiro estudo estatístico sobre o tema em âmbito federal. Há ainda o "Formulário de Visitação Anual (FVA)", que tem por objetivo a padronização dos dados de visitação das instituições.

Dentre as ações e programas destacamos a instituição do "Diretório de Grupos de Pesquisas" do Ibram junto ao Conselho Nacional de Desenvolvimento Científico e Tecnológico (CNPq), compondo uma base de dados com informações sobre os grupos de pesquisa no campo museológico em atividade no país, e o "Programa Nacional de Educação Museal” (PNEM). Esse programa vem sendo instituído desde 2011, por meio de construção participativa e colaborativa, e objetiva, principalmente, dar subsídios para as ações educativas em museus e fortalecer o campo de atuação profissional. O processo de construção do programa teve início com uma consulta pública em âmbito virtual e vem sendo discutido nas diferentes Redes de Educadores em Museus (REMs) e nos Encontro Regionais. Em 2014 foi realizado o $1^{\circ}$ Encontro Nacional do PNEM, evento no qual foi aprovada a "Carta de Belém”, com os princípios norteadores para uma política pública voltada à educação em museus. No ano de 2017, será realizado o $2^{\circ}$ Encontro Nacional do PNEM para que seja definido o documento final com as diretrizes orientadoras da educação museal. A constituição desse documento conta com a participação de profissionais que atuam nas próprias instituições, pesquisadores da área de educação em museus e museologia, funcionários da esfera pública, entre outros.

Nota-se assim, que nos últimos anos há um esforço realizado pelos diferentes agentes que atuam na área de educação em museus, com a chancela do Ibram, para a constituição de um discurso oficial relativo à educação museal.

No que concerne o financiamento na área cultural, destacamos o papel desempenhado pela Fundação Vitae. Criada em 1985, a associação de Apoio à Cultura, Educação e Promoção Social, tinha como objetivos promover o financiamento de programas, projetos e bolsas com recursos próprios (ALMEIDA 
e HERENCIA, 2012). De acordo com os autores, destaca-se a atuação da fundação nas ações de apoio a Museus de diferentes tipologias e vínculos institucionais, que tiveram início em 1994. Essas ações apoiaram projetos e programas voltados à preservação, documentação museológica e difusão (exposições de longa duração, desenvolvimento de programas educativos e de pesquisa de público). A fundação terminou suas atividades m 2005. Atualmente, as ações culturais no Brasil são incentivadas pela atuação da esfera governamental via diversas linhas de financiamento à projetos. No âmbito federal elas podem ocorrer com o apoio direto realizado pelo Ministério da Cultura e agências vinculadas (via Ibram) ou por meio de Renúncia Fiscal conforme a Lei Federal de Incentivo à Cultura (Lei Rouanet) ${ }^{15}$. Nos estados há também linhas de financiamento próprias por meio de leis de incentivo à cultura, via editais e por meio de isenção de Imposto de Circulação de Mercadorias e Serviços (ICMS). Há também atualmente, fundações mantidas por empresas privadas que atuam na área cultural, apoiando programas com recursos do campo da economia.

Notamos assim que há um importante movimento de valorização dos museus na área cultural, que culminou no lançamento da Política Nacional de Museus. No que se refere à educação, destacamos a valorização dessa função, presente entre os princípios da PNM, além do movimento de definição das diretrizes para a educação museal por meio do Programa Nacional de Educação Museal (PNEM). Mas por outro lado, é preciso destacar que a educação aparece de forma sintética e pouco definida no Estatuto de Museus, assim como é pouco privilegiada, de forma específica, nos editais de fomento do Ibram.

Além da área cultural, o trabalho de Martins (2011) identificou a atuação do Ministério da Ciência e Tecnologia (MCT) no desenvolvimento de políticas públicas para museus. Atualmente o Ministério da Ciência, Tecnologia, Inovações e Comunicações (MCTIC) ${ }^{16}$ possui 29 entidades entre elas, institutos e centros de pesquisa, empresas e laboratórios nacionais, agências de fomento científico

\footnotetext{
${ }^{15}$ A Lei Federal de Incentivo à Cultura (Lei no 8.313/91) institui o Programa Nacional de Apoio à Cultura (Pronac), que é formado por três mecanismos: o Fundo Nacional de Cultura (FNC), o Mecenato, e o Fundo de Investimento Cultural e Artístico (Ficart).

16 O Ministério da Ciência e Tecnologia foi criado por meio do Decreto no 91.146 de 15 de março de 1985. Em 2011 o termo "Inovação" foi a ele incorporado (Lei no 12.545, de 14 de dezembro de 2011). Em setembro de 2016, segundo a Lei no 13.341, o Ministério da Ciência, Tecnologia e Inovação - MCTI foi transformado em Ministério da Ciência, Tecnologia, Inovações e Comunicações, que também recebeu as competências do extinto Ministério das Comunicações - MC.
} 
(Financiadora de Estudos e Projetos- FINEP e o Conselho Nacional de Desenvolvimento Científico e Tecnológico - CNPq), além do Museu Paraense Emílio Goeldi e o Museu de Astronomia e Ciências Afins (MAST).

Em 2003, o MCT estabeleceu o "Programa de Difusão e Popularização do Conhecimento Científico e Tecnológico", com a criação do Departamento de Difusão e Popularização da Ciência e Tecnologia (DEPDI), vinculado à Secretaria de Ciência, Tecnologia e Inclusão Social (Secis) do MCT. Nesse programa, conforme Navas (2008), foi ressaltada a importância dos museus de ciências e tecnologia para a popularização do conhecimento científico e tecnológico, além do ensino de ciências no país. De acordo com a autora, o DEPDI incentivou diversas ações de apoio aos museus de ciências e tecnologia como o "Programa Ciência Móvel", "Semana Nacional de Ciência e Tecnologia", além dos editais destinados a museus e centros de ciências e para a difusão da ciência e tecnologia, Foi criado ainda, o Comitê de Divulgação Científica do CNPq. De acordo com Tuffani (2016), desde a criação da Secis em 2003, até o ano de 2016, a secretaria havia apoiado a criação e/ou fortalecimento de 180 museus e centros de ciências. Nota-se assim, que apesar das atribuições da SECIS via DEPDI tivesse como foco apoiar ações de divulgação científica em geral, várias ações foram voltadas aos museus e centros de ciências, mostrando a valorização dessas instituições para a difusão e popularização da ciência.

Em 2016, com a fusão entre o Ministério da Ciência, Tecnologia e Inovação e o Ministério das Comunicações, a Secretaria de Ciência, Tecnologia e Inclusão Social (Seped) foi extinta, sendo suas atribuições vinculadas à Secretaria de Políticas e Programas de Pesquisas e Desenvolvimento (Seped). Essa ação sofreu diversas críticas tanto dos funcionários da Secis, quanto d entidades relacionadas à ciência e divulgação, como a Academia Brasileira de Ciências (ABC). Dentre os argumentos contrários, um dos principais aspectos a ser destacado é a desvalorização das ações que vinham sendo desenvolvidas pela Secis.

Atualmente o MCTIC possui na área de atuação "Ciência, Tecnologia e Inovação para o Desenvolvimento Social”, a linha de ação "Popularização de C,T\&I e Melhoria do Ensino". Nessa linha de ação a inciativa "Desenvolvimento de espaços e iniciativas científico-culturais" contempla duas frentes, uma voltada ao “Apoio a Projetos e Eventos de Divulgação e de Educação Científica, Tecnológica 
e de Inovação" e outra destinada ao "Apoio à Criação e ao Desenvolvimento de Museus e Centros de Ciência e Tecnologia" (MCTIC, 2017a).

Levando em consideração outras tipologias de instituições museais, tais como jardins botânicos, zoológicos, aquários e unidades de conservação abertas à visitação ${ }^{17}$, nota-se que a conformação do campo recontextualizador oficial (CRO) nesses casos específicos pode também incluir outras agências e agentes. Essas tipologias de museus têm em comum coleções em que os elementos são vivos, além das finalidades de pesquisa e conservação in situ e/ou ex situ da biodiversidade, e de promover, junto ao público, a percepção das relações entre humanos e natureza, afim de conscientizar os indivíduos sobre a importância da conservação da biodiversidade e desenvolvimento sustentável (WILLISON, 2003; PEREIRA e COSTA, 2010; MEDEIROS e ARAÚJO, 2011; BARONGI et al., 2015).

No que concerne às questões ambientais, as instituições citadas respondem o Ministério do Meio Ambiente (MMA) e agências vinculadas em âmbito federal, além das secretarias estaduais e municipais de meio ambiente. Criado em novembro de 1992, o Ministério do Meio Ambiente tem como missão a promoção do conhecimento, proteção e recuperação do meio ambiente e uso sustentável dos recursos naturais. Além disso, são missões “a valorização dos serviços ambientais e a inserção do desenvolvimento sustentável na formulação e na implementação de políticas públicas em todos os níveis e instâncias de governo e sociedade" (MMA, 2017a).

Entre os órgãos vinculados ao ministério, há o Instituto de Pesquisas Jardim Botânico do Rio de Janeiro (JBRJ), Instituto Brasileiro do Meio Ambiente e dos Recursos Naturais Renováveis (IBAMA) e o Instituto Chico Mendes de Conservação da Biodiversidade (ICMBio). Esses órgãos atuam mais diretamente na promoção das políticas públicas de divulgação científica e educação ambiental. O MMA, via ICMBio, gere 327 Unidades de Conservação, das quais 72 são Parques Nacionais, cujas principais funções são de acordo com o Artigo 11 da Lei no. 9985 de 2000: “a realização de atividades educacionais e de interpretação

\footnotetext{
${ }^{17}$ As Unidades de Conservação possuem diferentes tipos de uso, segundo a classe a que pertencem. Essas categorias são definidas pelo Sistema Nacional de Unidades de Conservação da Natureza (SNUC), sistema instituído em julho de 2000 (Brasil. Ministério do Meio Ambiente. SNUC - Sistema Nacional de Unidades de Conservação da Natureza: Lei no 9.985, de 18 de julho de 2000).
} 
ambiental, recreação e turismo ecológico, por meio do contato com a natureza", devendo permanecer abertos à visitação (BRASIL, 2000a) ${ }^{18}$.

A Política Nacional de Educação Ambiental (PNEA) foi instituída em 199919, tendo suas origens na constituição de 1988, a qual destaca no Artigo 225 a necessidade de "promover a Educação Ambiental em todos os níveis de ensino e a conscientização pública para a preservação do meio ambiente" (BRASIL, 1988). A Política Nacional de Educação Ambiental é resultado de uma ampliação da importância da educação ambiental em diferentes contextos. Em 1989, dando continuidade a implementação da Política Nacional de Meio Ambiente (PNMA), é criado o IBAMA que foi instituído como o órgão executor dessa política. De acordo com Cruz (2014), à época, o IBAMA incorporou em sua estrutura a educação ambiental, com foco nas políticas para formação de educadores ambientais. Ainda segundo a autora, nesse processo e de forma mais explicita a partir de 1997, há uma valorização da educação ambiental, que se consolida neste instituto como "educação no processo de gestão ambiental". Nesse momento, as ações são coordenadas pela equipe da CGEAM (Coordenação Geral de Educação Ambiental) em Brasília e pelos NEAs (Núcleos de Educação Ambiental) nas estruturas locais e regionais do IBAMA em todo o país.

Em 2002 foi criado o Órgão Gestor da Política Nacional de Educação Ambiental, integrado pelo MMA e Ministério da Educação (MEC). Os ministérios são responsáveis pela coordenação dessa política de forma compartilhada na tomada de decisões para a criação de instrumentos públicos para a consolidação da educação ambiental no Brasil (MMA/MEC, 2014).

No Artigo 2 da Lei no. 9795 de 1999, a PNEA destaca a educação ambiental como "componente essencial e permanente da educação nacional, devendo estar presente, de forma articulada, em todos os níveis e modalidades do processo educativo, em caráter formal e não-formal” (BRASIL, 1999). O conceito de educação ambiental disposto pela PNEA destaca-a como um processo de construção individual e coletiva que inclui valores, conhecimentos, habilidades, atitudes e competências voltadas para a conservação do meio ambiente. Os objetivos da lei apontam para que seja desenvolvida "uma

\footnotetext{
${ }^{18}$ Nem todos os Parques encontram-se abertos à visitação. Isso pode estar relacionado ao fato de não possuírem os Planos de Manejo concluídos ou adequados.

19 Lei no 9.795 de abril de 1999.
} 
compreensão integrada do meio ambiente em suas múltiplas e complexas relações, envolvendo aspectos ecológicos, psicológicos, legais, políticos, sociais, econômicos, científicos, culturais e éticos" (BRASIL, Lei no 9795, 1999. Art. 5). Essa abordagem multidimensional e integradora do meio ambiente aparece também no artigo $4^{\circ}$, que trata dos princípios básicos da educação ambiental, destacando a interdependência entre natureza, meio socioeconômico e cultural. Além disso, os objetivos destacam também o amplo acesso à informação, e o fortalecimento da conscientização crítica e a atuação cidadã acerca da preservação do meio ambiente.

Nas Diretrizes Curriculares Nacionais para a Educação Básica é reconhecido o papel relevante da educação ambiental, obrigatória em todas as suas etapas e modalidades. E em 2012 o Conselho Nacional de Educação (CNE) do Ministério da Educação estabeleceu as Diretrizes Curriculares Nacionais para a Educação Ambiental ${ }^{20}$. Nessas diretrizes o conceito de educação ambiental é apresentado como uma atividade humana que deve ter em consideração o caráter social e ético da relação entre os indivíduos com a natureza e com os outros seres humanos (CNE, 2012).

Em 2004, a partir de consulta pública, o Órgão Gestor da Política Nacional de Educação Ambiental lança o Programa Nacional de Educação Ambiental (ProNEA). As ações do ProNEA têm como objetivo a integração multidimensional da sustentabilidade, contribuindo para o desenvolvimento do país e assegurado a qualidade de vida para a população. 0 programa reforça o caráter colaborativo de seu desenvolvimento, ao destacar que além de determinar diretrizes para as políticas públicas na área, o programa é sobretudo, um instrumento de participação social com representatividade em todos os segmentos sociais e esferas governamentais na sua formulação, execução, monitoramento e avaliação.

Atualmente o ProNEA está a cargo do Departamento de Educação Ambiental do MMA, que atua no planejamento, execução e avaliação das políticas públicas de educação ambiental, por meio de três linhas de ação: Gestão e

\footnotetext{
${ }^{20}$ Desde 2007 o Conselho Nacional de Educação com a participação de representantes das Instituições de Ensino, da sociedade civil e agências governamentais, discutem as diretrizes para a educação ambiental que foram aprovadas, por meio da Resolução CNE/MEC no. 02, de 15/06/2012.
} 
Planejamento da Educação Ambiental no País; Formação de Educadoras e Educadores Ambientais; Comunicação para Educação Ambiental (Educomunicação). Essas três linhas de ação são trabalhadas de forma articulada pelo departamento e integrada com as Secretarias do Ministério do Meio Ambiente, o IBAMA, a Agência Nacional de Águas e o Instituto Jardim Botânico do Rio de Janeiro.

No que se refere às frentes de financiamento de ações e programas, há o Fundo Nacional do Meio Ambiente (FNMA), constituindo uma unidade do MMA para a implementação da Política Nacional do Meio Ambiente (PNMA). 0 fundo atua no fomento para projetos, disponibilizando recursos por meio de demanda espontânea ou por chamadas específicas, incluindo editais em consonância com as ações desenvolvidas pelo Departamento de Educação Ambiental. O MMA possui ainda outros fundos e linhas de apoio a projetos, geralmente vinculadas a áreas específicas de atuação do ministério, como é o caso do Fundo Amazônia, Fundo Nacional sobre Mudança do Clima, Carteira Indígena, entre outros, não havendo porém, uma linha de fomento específica para a educação ambiental.

A educação ambiental é a dimensão educacional legitimada nas instituições como jardins botânicos, aquários, zoológicos e parques, os quais apresentam geralmente, setores ou núcleos de educação ambiental destinados à pesquisa, desenvolvimento e realização de ações junto à população. Ainda que não se trate de aprofundar a discussão sobre as inter-relações entre a educação ambiental e a educação em museus, é importante denotar que as políticas públicas relacionadas à educação ambiental, assim como as agências e agentes que atuam nessa área, constituem os discursos e os campos recontexualizadores que participam dos processos de produção dos discursos pedagógicos de reprodução presentes nesses espaços. No entanto, à semelhança do que ocorre com o papel que a educação assume entre as definições, políticas públicas e práticas dos museus, a educação ambiental ocupa posições mais ou menos destacadas nas políticas, programas e instituições. No que se refere especificamente aos jardins botânicos, vale lembrar que a educação ambiental tem origem na década de 1970, sendo um dos últimos aspectos a ser inseridos entre as práticas dessas instituições, que há séculos possuem funções de cultivo, preservação, documentação e estudo das plantas. 
Com o que foi exposto anteriormente, notamos que a presença de diferentes agências e agentes que conformam o campo de recontextualização oficial tem relação com a diversidade de tipologias de instituições que podem ser consideradas museus e com os tipos de vinculação dessas instituições às agências ao nível da geração dos discursos (Campo do Estado, Campo do controle simbólico, Campo da Economia). Para além do MinC, MCTIC e MMA, outras agências podem possuir entre seus objetivos e linhas de ação a educação, comunicação e divulgação em espaços museais. A figura 3.1 traz uma síntese das principais agências que atuam no CRO dos museus, destacando suas políticas públicas voltadas à educação, e as principais tipologias de instituições museais influenciadas por tais políticas.

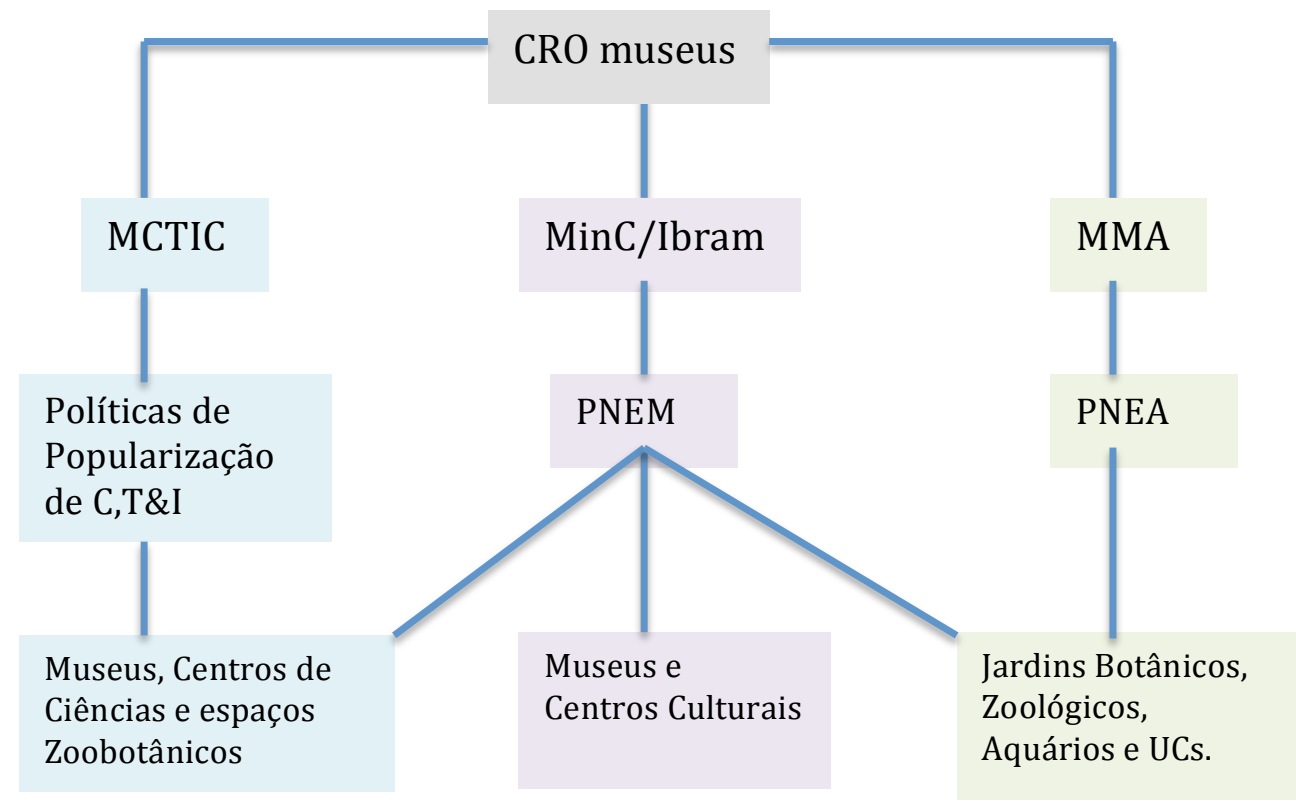

Figura 3.1: Esquema das agencias e principais políticas do Campo de Recontextualização Oficial dos Museus. CRO: Campos Recontextualizador dos museus; MCTIC: Ministérios da Ciência, Tecnologia, Inovação e Comunicações; MinC/Ibram: Ministério da Cultura/ Instituto brasileiro de Museus; MMA: Ministério do Meio Ambiente; PNEM: Programa Nacional de Educação Museal; PNEA: Política Nacional de Educação Ambiental; C,T\&I: Ciência, Tecnologia e Sociedade; UCs: Unidades de Conservação.

Diferentes linhas de financiamento são destinadas às ações educativas em espaços não formais. Para além de investimentos oriundos do vínculo com agências do Estado ou do campo da Economia, as instituições museais podem obter financiamento por meio de editais e programas de outras agências, órgãos ou entidades, como por exemplo pelas agências de fomento CNPq e FINEP. Essas 
linhas de financiamento, encontram-se polarizadas em diferentes áreas - e.g. cultura, ciência e tecnologia, meio ambiente, e implementam diferentes políticas públicas relacionadas à educação em museus.

Ainda no que se refere ao campo de recontextualização oficial e do discurso pedagógico oficial dos museus, ressaltamos a recente constituição do campo de pesquisa na área de educação em museus. 0 número de agentes e agências, situados no campo do controle simbólico e que regulam as possibilidades dos recursos discursivos da área em questão, vem crescendo nas últimas décadas. Assim, há uma maior produção e legitimação dos discursos específicos da educação em museus, que podem estar mais presentes nos discursos oficiais.

É possível notar pela quantidade de publicações, que o movimento mundial de crescimento da área de pesquisa ocorreu a partir da década de 1990, e mais acentuadamente a partir do início do século XXI. O número de pesquisas que apresentam as palavras "educação" e "museus" no portal do Scopus (https://www.scopus.com/home.uri), desde 1888 até Junho de 2017, totaliza 3500 publicações. De 2001 a 2016 foram publicados 2937 trabalhos, segundo esse critério de busca ${ }^{21}$.

A pesquisa realizada por Ovigli (2013) mostra que no contexto brasileiro, especificamente sobre a produção científica relacionada aos museus e centros de ciências, o número de dissertações e teses defendidas aumentou significativamente a partir de 2001. Considerando o período de 1971 a 2010, há 153 trabalhos no banco de dados da CAPES, sendo que mais de 80\% deles foram concluídos a partir de 2001. Dentre os assuntos tratados nos trabalhos levantados pelo autor, são mais frequentes (1) as análises de programas, ações e exposições, (2) as pesquisas de aprendizagem em educação não formal e (3) as investigações sobre formação de professores, correspondendo a cerca de $20 \%$ dos trabalhos cada um dos três itens acima citados.

Por conta das características mencionadas, é possível afirmar que o CRO dos museus pode ser constituído tanto pelas instituições oficiais com as quais

\footnotetext{
${ }^{21}$ A busca foi realizada em 11 de Junho de 2017 com os termos "education" AND "museum" para título, resumo e palavras-chave.
} 
mantêm relações diretas, quanto aquelas que estão indiretamente ligadas a eles. Ainda com base nas características expostas, notamos que há diferentes textos e discursos pedagógicos oficiais, e que esses assumem vieses distintos conforme a agência e agentes que atuam nos campos de recontextualização, dando espaço à realização de diferentes mensagens.

\subsubsection{Políticas e textos oficiais sobre biodiversidade}

Retomando o contexto no qual foi realizada esta investigação - exposições imersivas sobre biomas brasileiros sediadas em jardins botânicos, e os objetivos da pesquisa que contemplam a análise do discurso expositivo sobre biodiversidade, buscamos a seguir apresentar alguns aspectos dos textos oficiais sobre biodiversidade e sobre os biomas apresentados nas exposições.

Como já afirmamos anteriormente, a biodiversidade é um tema de grande destaque na sociedade atual, principalmente por conta do avanço dos problemas ambientais, mas também por outros aspectos que dizem respeito às relações entre humanos e natureza, e às potencialidades econômicas e sociais dos serviços ambientais.. A biodiversidade é um termo para o qual não há uma definição técnico-científica consensual e que permite diversos pontos de vista. Assim ela pode ser definida desde uma perspectiva simbólica até um enfoque operacional, como é o caso das definições relacionadas às políticas de conservação (LEWINSOHN e PRADO, 2002; TRAJANO, 2010). Discutiremos mais detalhadamente os conceitos e aspectos relacionados ao termo biodiversidade no capítulo 4, nos atendo nesse momento aos textos oficiais, no sentido de destacar as políticas de divulgação, comunicação e educação sobre o tema.

A biodiversidade aparece em destaque no textos do $\mathrm{MMA}^{22}$, apresentando para além do conceito e de dados da riqueza biológica do Brasil, uma relação de programas do ministério voltados ao tema (MMA, 2017b). Um primeiro aspecto que merece destaque é a apresentação da posição do Brasil frente aos acordos internacionais como a Convenção da Diversidade Biológica (CDB). Em 1994, o governo brasileiro criou o Programa Nacional da Diversidade Biológica

\footnotetext{
22 A biodiversidade constitui um dos marcadores de assuntos na página inicial do portal do MMA <http://www.mma.gov.br> Acesso em 13 fev. 2017.
} 
(PRONABIO) ${ }^{23}$ no sentido de implementar os compromissos da CDB. E em 1996, com a assinatura de um acordo de doação entre o governo brasileiro e o Banco Internacional Internacional para a Reconstrução e Desenvolvimento (BIRD), foi executado o Projeto de Conservação e Utilização Sustentável da Diversidade Biológica Brasileira (Probio I).

Esse projeto, elaborado com vistas ao financiamento de ações para a implementação do PRONABIO, foi coordenado pelo MMA em parceria com o Conselho Nacional de Desenvolvimento Científico e Tecnológico (CNPq). De acordo com Lerner (2008), o ProBio I tinha entre seus objetivos a identificação das ações prioritárias para implementação do PRONABIO, por meio do incentivo a subprojetos envolvendo os setores público e privado. 0 projeto permitiu agregar uma diversidade de informações e envolveu, segundo Trajano (2010), mais de mil cientistas, técnicos de órgãos públicos e ONGs e lideranças de movimentos sociais. Para a autora esse é um documento bastante robusto e com sólida fundamentação científica, legitimado junto aos diversos setores da sociedade. No que se refere à educação, o escopo do Probio I inclui dentre as linhas temáticas dos subprojetos apoiados, o tema "Educação Ambiental, Informação e Divulgação da Biodiversidade".

O Probio I foi sucedido pelo "Projeto Nacional de Ações Integradas Público-Privadas para Biodiversidade" (Probio II), que teve inicio em 2005 e foi estabelecido por meio da parceria entre o MMA, o Fundo Brasileiro para a Biodiversidade (Funbio) e a Caixa Econômica Federal. Foram também realizadas parcerias com outros ministérios e institutos de pesquisa para a implementação do projeto, tais como a Fundação Oswaldo Cruz (FIOCRUZ) e o Instituto de Pesquisas Jardim Botânico do Rio de Janeiro (JBRJ).

A partir de 2002, o MMA, por meio do PRONABIO, passou a implementar as diretrizes e princípios da Política Nacional da Biodiversidade (PNB) ${ }^{24}$. Em 2003, a estrutura do PRONABIO foi modificada, com ampliação de seu escopo e atribuições, além da representação de sua comissão coordenadora, que passou a

\footnotetext{
23 Brasil, 1994. Decreto 1.354 de 29 de dezembro de 1994. Institui, no âmbito do Ministério do Meio Ambiente e da Amazônia Legal, o Programa Nacional da Diversidade Biológica, e da outras providências. Disponível em <http://www.planalto.gov.br/ccivil_03/decreto/D1354.htm> Acesso em: 15 fev. 2017.

24 Brasil, 2002a. Decreto 4.339 de 22 de agosto de 2002. Institui princípios e diretrizes para a implementação da Política Nacional da Biodiversidade. Disponível em <http://www.planalto.gov.br/ccivil_03/decreto/2002/D4339.htm> Acesso em: 15 fev. 2017.
} 
ser denominada Comissão Nacional da Biodiversidade (Conabio), com representantes das diversas esferas de governo e sociedade civil (BRASIL, 2003). Além de acompanhar e implementar os compromissos da $\mathrm{CDB}$, compete à essa comissão, a discussão e implementação das politicas públicas sobre a biodiversidade. Em 2006 foi divulgado o Plano de Ação para a Implementação da Política Nacional da biodiversidade (PAN-Bio), no qual se nota a ênfase à descentralização das ações, e compartilhamento de responsabilidades entre diversas esferas governamentais (PAULO, 2016). Os componentes e diretrizes da PAN-Bio seguem a PNB.

A Política Nacional da Biodiversidade foi formulada a partir de um processo de consulta realizado entre 2000 e 2001, do qual participaram agentes de diversas esferas de governo, organizações não-governamentais, comunidade acadêmica, sociedade civil, populações tradicionais e empresas. 0 MMA realizou também cinco avaliações sobre os biomas brasileiros, com o levantamento de áreas prioritárias para a conservação. Com base nessas avaliações, nos resultados da consulta nacional e das reuniões posteriores, foi desenvolvido o documento da PNB, instituída por decreto em 2002. A política possui como componentes temáticos centrais: conhecimento da biodiversidade; conservação da biodiversidade; uso sustentável dos componentes da biodiversidade; acompanhamento, avaliação, prevenção e mitigação dos impactos sobre a biodiversidade; acesso aos recursos genéticos e aos conhecimentos tradicionais da biodiversidade e, repartição dos benefícios; educação e sensibilização pública ${ }^{25}$; fortalecimento jurídico e institucional para a gestão da biodiversidade (BRASIL, 2002a).

É com base nos artigos da Convenção da Diversidade Biológica (CDB) que a educação é inserida na PNB. No entanto, como chama atenção Cruz (2014), a educação como componente dessa política aparece associada a elementos da comunicação, apontando para o papel da educação apenas para a divulgação da biodiversidade. A autora discute, ainda, que essa associação está presente

\footnotetext{
250 componente 6 da PNB “Educação, Sensibilização Pública, Informação e Divulgação sobre Biodiversidade", tem como diretriz em primeiro lugar, a informação, a divulgação; em segundo lugar vem a sensibilização pública; e em terceiro a "Incorporação de temas relativos à conservação e à utilização sustentável da biodiversidade na educação" (BRASIL, 2002a. Decreto no. 4.339, de 22 de agosto de 2002. Institui princípios e diretrizes para a implementação da Política Nacional da Biodiversidade. Disponível em: http://www.mma.gov.br/port/conama/legiabre.cfm?codlegi=363). Acesso em: 03 mar. 2017.
} 
também no Plano Estratégico nacional de Áreas Protegidas (PNAP)26, política pública instituída em 2006, no âmbito dos compromissos assumidos com a CDB. Entre os objetivos específicos do PNAP para educação e comunicação aparecem a implementação da estratégia nacional de educação ambiental em unidades de conservação (ENCEA) e da estratégia de comunicação, divulgação e sensibilização sobre unidades de conservação. Vale lembrar que anteriormente a essas duas políticas relacionadas à área ambiental, que incluem entre seus objetivos a educação e comunicação, foi instituída a Política Nacional de Educação Ambiental (PNEA), descrita anteriormente.

Dentre as ações e políticas relacionadas à biodiversidade, destacamos também a atuação do Ministério da Ciência Tecnologia Inovações e Comunicações (MCTIC). Atualmente está em execução a Estratégia Nacional de CT\&I (2016 a 2019), que dá continuidade a Estratégia Nacional de CT\&I 20122015 (ENCTI) e o Plano de Ação em Ciência, Tecnologia e Inovação 2007-2010 (PACTI). Esse plano constituiu um instrumento norteador das ações de Estado para ciência, tecnologia e inovação no período de atividade. 0 plano é composto por quatro prioridades estratégicas, com 21 linhas de ação, nas quais encontramse 87 programas (MCT, 2010). No que se refere à biodiversidade, a prioridade IV de "Pesquisa, Desenvolvimento e Inovação em Áreas Estratégicas" das ações do ministério, inclui a linha "Biodiversidade e Recursos Naturais", sendo os principais objetivos dessa linha a proteção da biodiversidade nacional e dos recursos econômicos e o desenvolvimento de práticas eficazes de manejo.

De acordo com Oliveira (2016), durante o período do PACTI, houve o lançamento dos Institutos Nacionais de Ciência e Tecnologia (INCT), envolvendo no âmbito federal o Conselho Nacional de Desenvolvimento Científico e Tecnológico (CNPq) do MCTIC e a Comissão de Aperfeiçoamento de Pessoal do Nível Superior (CAPES), órgão do Ministério da Educação. Além disso, envolveram-se também as Fundações de Pesquisa (FAPs) em diversos estados e no Distrito Federal. Os objetivos dos INCTs seguiram as áreas prioritárias do documento do PACTI 2007-2010, das quais destacam-se a biodiversidade. Entre as prioridades dos INCTs, Oliveira (op. cit.) aponta ainda a promoção da divulgação de conhecimento em contextos variados e por meio de diferentes

${ }^{26}$ O PNAP é estabelecido por meio do decreto 5.758, de 13 de abril de 2006. 
estratégias, com foco na educação científica para o ensino médio e público em geral.

Entre os programas relacionados à biodiversidade, realizados pelo MCTIC-CNPq, destacamos também o "Programa de Pesquisas Ecológicas de Longa Duração" (PELD), o "Programa de Pesquisa em Biodiversidade” (PPBio) e o "Sistema Nacional de Pesquisa em Biodiversidade" (SISBIOTA).

O PELD teve início na década de 1990 e sua implementação está ligada à identificação e seleção de sítios de pesquisas representativos dos ecossistemas brasileiros (BARBOSA, 2013). De acordo com a apresentação do programa no portal do $\mathrm{CNPq}^{27}$, além da geração de conhecimento sobre os nossos ecossistemas e a biodiversidade, é objetivo do PELD a divulgação do conhecimento gerado para o público em geral (MCTIC, 2017b). Curiosamente, a divulgação não aparece entre os objetivos principais do programa descritos na Resolução Normativa 023 de 2011, estando presente, no entanto, nas diretrizes do programa no edital de $2009^{28}$ e nas disposições específicas da chamada de $2012^{29}$, as quais obrigam as propostas a preverem um componente de divulgação do conhecimento à sociedade.

O "Programa de Pesquisa em Biodiversidade" (PPBio) foi criado em 2004, seguindo as diretrizes PNB, contendo em sua estrutura eixos de ação que enfatizam a implantação e manutenção de redes de inventário da biota, apoio à pesquisa e desenvolvimento em área temáticas da biodiversidade, desenvolvimento de ações estratégicas para políticas de pesquisa, ampliação da divulgação de informação sobre a diversidade biológica para diferentes setores da sociedade, além do apoio à modernização e integração entre acervos biológicos ex-situ (MCT, 2005).

Sobre esse último item, de especial interesse para a área de museus, o documento básico do PPBio destaca a importância das coleções biológicas em termos científico, econômico e educacional. 0 documento enfatiza ainda a falta

\footnotetext{
27 <http://cnpq.br/apresentacao-peld> Acesso em: 03 mar. 2017.

28 Edital MCT/CNPq no 59/2009 - PELD disponível em <http://cnpq.br/web/guest/chamadaspublicas?p_p_id=resultadosportlet_WAR_resultadoscnpqportlet_INSTANCE_0ZaM\&idDivulgacao=61\&filtro= encerradas\&detalha=chamadaDetalhada\&id=47-73-994> Acesso em: 03 mar. 2017.

${ }^{29}$ Chamada MCTI/CNPq/FAPs № 34/2012 - Programa de Pesquisa Ecológica de Longa Duração - PELD disponível em <http://cnpq.br/chamadaspublicas?p_p_id=resultadosportlet_WAR_resultadoscnpqportlet_INSTANCE_0ZaM\&filtro=resultados\&detalh $\mathrm{a}=$ chamadaDivulgada\&idDivulgacao=2121 > Acesso em: 03 mar. 2017.
} 
de apoio para a conservação desses acervos, catalogação e para a divulgação de "informações sobre a biodiversidade para múltiplos usuários, entre eles os órgãos encarregados da gestão da biodiversidade, as universidades e escolas, o setor privado e a sociedade em geral" (MCT, 2005, p. 25). Assim, esse eixo é criado com vistas a criação de uma política de gerenciamento desses acervos, identificação de coleções de referência, apoio à manutenção, ampliação e digitalização dos acervos, além de fomentar a capacitação de recursos humanos e a integração das coleções.

As atividades iniciais do programa ocorreram na Região Amazônica e foram expandidas para a região do Semiárido. Em 2012, por meio da Chamada MCT/CNPq no 35/2012 - PPBio/Geoma, o programa foi ampliado, com a constituição de sete redes de pesquisa em cinco regiões fitogeográficas: Amazônia Ocidental, Semiárido, Cerrado, Mata Atlântica e Campos Sulinos.

O "Sistema Nacional de Pesquisa em Biodiversidade" (SISBIOTA) foi lançado em 2010 como uma iniciativa conjunta entre os ministérios da Ciência e Tecnologia, da Educação e do Meio Ambiente, Fundo Nacional de Desenvolvimento Científico e Tecnológico (FNDC), CAPES, CNPq e de 18 fundações de amparo à pesquisa estaduais (FAPs). Para além de fomentar e ampliar o conhecimento da biodiversidade do país, o programa objetiva melhorar a capacidade de realizar previsões acerca das mudanças globais. 0 SISBIOTA destaca ainda a importância da articulação das pesquisas com a formação de indivíduos, educação ambiental e divulgação do conhecimento científico. O programa teve seu primeiro Edital lançado em 201030, com aprovação de projetos de pesquisa nos sete biomas brasileiros (Amazônia, Caatinga, Cerrado, Pantanal, Mata Atlântica, Pampa e Zona Costeiro-Marinha).

Ainda como parte das iniciativas do Ministério da Ciência, Tecnologia, Inovações e Comunicações (MCTIC), destacamos o "Sistema de Informação sobre a Biodiversidade Brasileira" (SiBBr), projeto iniciado oficialmente em 2012, com o objetivo de consolidar uma infraestrutura nacional de dados e conteúdos em biodiversidade, integrando os bancos de dados dispersos pelo país. 0 projeto contou com o suporte técnico do Programa das Nações Unidas para o Meio

\footnotetext{
${ }^{30}$ Edital MCT/CNPq/MMA/MEC/CAPES/FNDCT - Ação Transversal/FAPs № 47/2010
} 
Ambiente (PNUMA) e foi financiado pelo Fundo Global para o Meio Ambiente (GEF). 0 portal do sistema foi publicado na rede em 2014, com um conjunto de ferramentas e serviços para busca de conteúdos e publicação ativa de dados e pesquisas acadêmicas. $0 \mathrm{SiBBr}$ está ainda integrado à Plataforma Global de Informação sobre Biodiversidade (GBIF, na sigla em inglês), que contem informações sobre biodiversidade de aproximadamente 60 países.

Pelo que foi exposto sobre a política e os programas sobre biodiversidade, notamos que a partir da década de 1990 e especialmente a partir de 2000, há uma profusão de diferentes estratégias para a ampliação do conhecimento sobre a diversidade biológica do país, com formas diversas de financiamento à pesquisa, apoio à constituição de redes de referência e criação de sistema de organização e gerenciamento de dados. Além disso, os documentos buscam contemplar a educação e/ou divulgação desses conhecimentos para a sociedade. No entanto, não há um programa específico de educação ou divulgação, sendo que estes aspectos aparecem de maneira pulverizada nos diversos programas. Conforme foi dito, parte desses planos, programas e seus projetos, como o Probio I e II, Plano Estratégico de Áreas Protegidas (PEAP) e o Sisbiota não enfatizam a educação especificamente, abordando-a de forma conjunta com a divulgação científica, mas destacam a importância de que os projetos de pesquisa contemplados tenham atuação nesses campos. O PELD contempla apenas a divulgação e o $\mathrm{SiBBr}$, ainda que não a mencione entre seus objetivos principais, a divulgação científica é atividade óbvia dado que o sistema está disponível para acesso na rede (figura 3.2). 


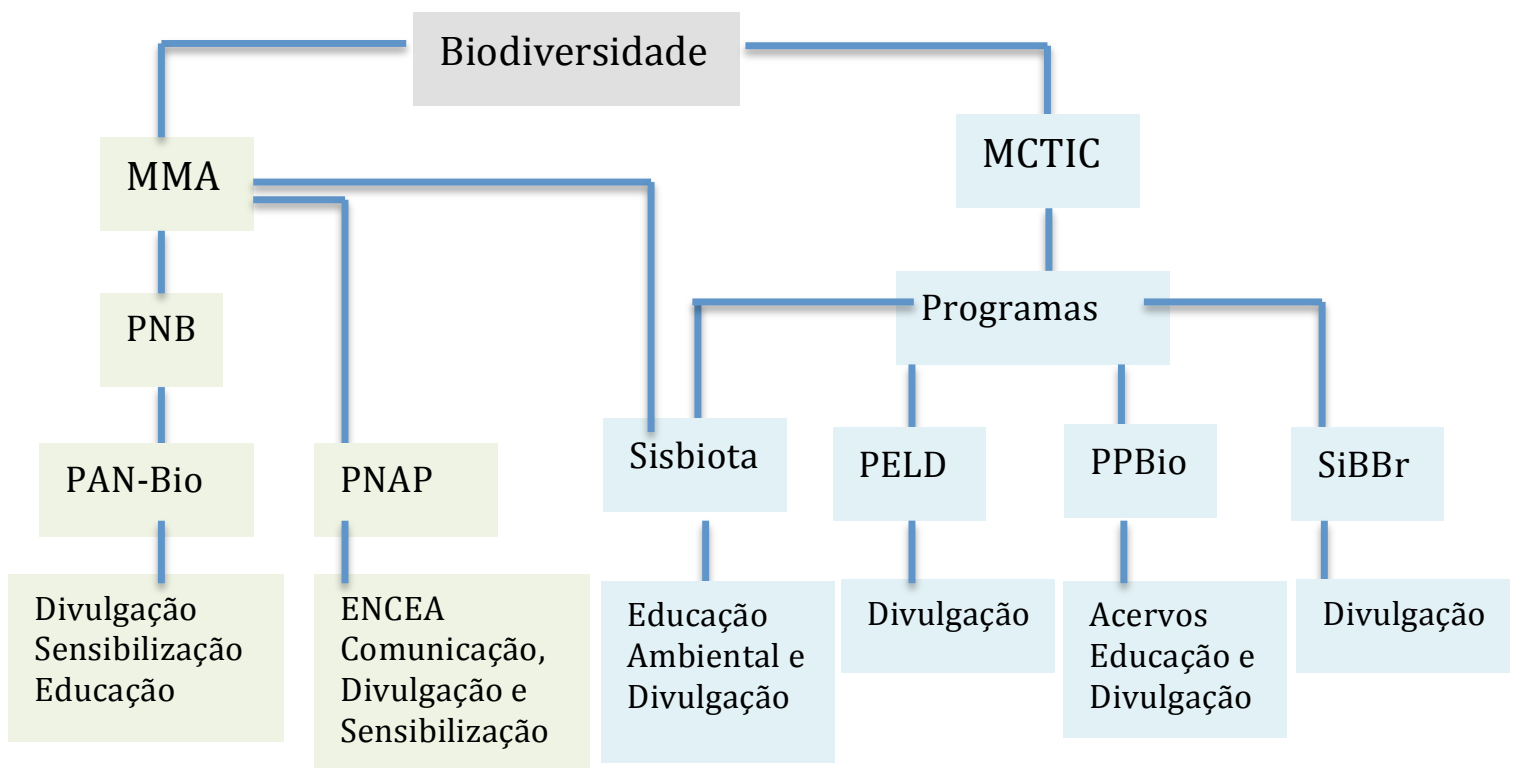

Figura 3.2: Esquema dos principais programas relacionados à biodiversidade em âmbito federal, que incluem diretrizes ou linhas de ação em educação e/ou divulgação. MMA: Ministério do Meio Ambiente; MCTIC: Ministério da Ciência, Tecnologia, Inovação e Comunicações; PNB: Política Nacional de Biodiversidade; PAN-Bio: Plano de Ação para a Implementação da Política Nacional da biodiversidade; Sisbiota: Sistema Nacional de Pesquisa em Biodiversidade; PELD: Programa de Pesquisas Ecológicas de Longa Duração; PPBio: Programa de Pesquisa em Biodiversidade; SiBBr: Sistema de Informação sobre a Biodiversidade Brasileira; ENCEA: Estratégia Nacional de Educação Ambiental em unidades de conservação.

Ainda que não haja uma proeminência das ações de educação e divulgação nos programas e politicas de biodiversidade, é preciso ressaltar que vários projetos vêm realizando diferentes tipos de ações, incluindo entre elas o desenvolvimento de atividades educativas em espaços museais, tais como exposições (OLIVEIRA, 2016; MARANDINO, SOUZA e PUGLIESE, 2017). Os trabalhos realizados por essas autoras destacam a necessidade de dar relevância ao papel da educação e divulgação da biodiversidade nos documentos oficiais da área, estabelecendo parâmetros para compreender diferentes aspectos dessas ações, incluindo os impactos delas sobre os públicos a que se destinam.

Por fim, concluímos, pela análise dos documentos oficiais, que os programas e projetos visam a criação de redes e financiam ações no país todo, agregando diferentes agências no âmbito estadual, buscando "cobrir" todos os biomas brasileiros. 


\subsubsection{Programas e textos oficiais sobre a Caatinga e o Cerrado}

Considerando os dois biomas representados nas exposições analisadas neste trabalho, apresentamos a seguir alguns programas e textos oficias sobre a Caatinga e o Cerrado. O levantamento desses programas foi feito apenas no âmbito das agências federais. Isso se deve tanto ao fato das políticas desenvolvidas nesse âmbito embasarem aquelas geradas nos níveis estadual e municipal, quanto à consideração de que um mesmo bioma se estende por diversos estados, fazendo com que as ações fiquem centralizadas nos órgãos e entidades vinculados à esfera federal.

Como apresentado anteriormente, o PPBio (MCTIC-CNPq) iniciado na Amazônia expandiu-se para o Semiárido, constituindo a Rede do Semiárido e dando continuidade a construção de conhecimentos iniciados pelo Instituto Virtual do Milênio do Semiárido (IMSEAR). Como objetivo do PPBio nos diferentes biomas, o PPBio do Semiárido articula diversas instituições, principalmente da Região Nordeste, com a participação de 24 instituições de pesquisa. Entre as ações realizadas no escopo do programa há a caracterização da biodiversidade, qualificação de recursos humanos e o levantamento da biota do semiárido por meio de uma rede de inventários, com a ampliação das coleções científicas existentes (CARDOSO, 2009).

Em 2014 o governo federal lançou o Sistema de Gestão da Informação e do Conhecimento do Semiárido Brasileiro (SIGSAB), com o objetivo de agrupar e divulgar dados e informações socioeconômicas, ambientais e da infraestrutura do Semiárido brasileiro. A ferramenta foi desenvolvida pelo Instituto Nacional do Semiárido (INSA-MCTIC) para funcionar em uma plataforma na web. Além de reunir e divulgar informações, o sistema tem como objetivo contribuir para a definição de políticas públicas, investimentos e para o planejamento do uso sustentável dos recursos presentes no semiárido (INSA, 2017).

Por meio da ação conjunta do INSA, MCTIC e CNPq diversos projetos vêm sendo realizados no semiárido por meio de editais. Em consonância com outros editais do MCTI e CNPq discutidos anteriormente, há nesses projetos a necessidade de contemplar ações de educação e/ou divulgação. Fruto dos projetos apoiados, o INSA lançou alguns livros sobre ações de educação e divulgação desenvolvidas, como é o caso do "Educação Contextualizada para a 
convivência com o Semiárido brasileiro: debates atuais e estudos de caso" (CUNHA, SANTOS, PEREZ-MARIN, 2014) e o "Vivências e práticas para a coabitação no Semiárido: ensaios e reflexões" (SANTOS, CUNHA, DENIS, PEREZMARIN, 2016) ${ }^{31}$. Além dessas publicações, o instituto tem realizado outras ações e publicado obras de educação ambiental para diversos públicos, destinados à divulgação da biodiversidade da Caatinga, no contexto do Programa Semiárido em Foco.

Vale destacar também o edital do ICMBIO (MMA) e CNPq (MCTI) no 13 de 2011 fomentou pesquisas em Unidades de Conservação do bioma da Caatinga, com o objetivo de contribuir para o desenvolvimento científico e tecnológico relacionados ao manejo, uso e conservação da biodiversidade, e a proteção do patrimônio cultural e dos recursos naturais nas Unidades de Conservação (UCs) e entorno. Para atender essa chamada, as propostas tinham que contemplar ações de divulgação do conhecimento gerado pela pesquisa, tendo como públicoalvo gestores das Unidades de Conservação, comunidades locais, além de formuladores de políticas públicas ambientais. Como parte do processo de avaliação da chamada foi produzida a publicação "Pesquisas em Unidades de Conservação no domínio da Caatinga: subsídios à gestão", que traz entre as análises dos diferentes aspectos das pesquisas desenvolvidas no âmbito da chamada, um capítulo dedicado avaliação das ações de divulgação e educação realizadas (MANTOVANI, MONTEIRO e CARIELLO, 2017).

Quanto à atuação do MMA, vale destacar os projetos apoiados por meio do Fundo Clima (MMA/BNDES), do Fundo Socioambiental (MMA/Caixa econômica Federal) e Fundo Caatinga (Banco do Nordeste). Com o aporte de recursos desses fundos foram criadas Unidades de Conservação e fomentados projetos para uso sustentável de recursos naturais, como por exemplo o projeto "Manejo do Uso Sustentável da Terra no Semiárido do Nordeste Brasileiro", coordenado pelo ministério em cooperação com o Programa das Nações Unidas para o Desenvolvimento (PNUD), com recursos do Fundo Global para o Meio Ambiente (GEF).

As questões sobre o manejo e uso sustentável dos recursos no semiárido

\footnotetext{
31 Os livros estão disponíveis em: <https://portal.insa.gov.br/noticias/285-insa-e-cnpq-lancam-obras-
} sobre-educacao-contextualizada-e-convivencia-com-o-semiarido-brasileiro-3> Acesso em 17 maio 2017. 
estão contempladas em diversas publicações do MMA sobre assunto. Além dos guias de manejo e uso sustentável, entre as publicações do ministério, encontramos levantamentos de áreas prioritárias para a conservação e estratégias para manutenção de UCs, além do Plano de Divulgação do Bioma Caatinga. Essa publicação tem como intuito subsidiar diretrizes de comunicação para diferentes públicos, contribuindo para que os objetivos de conservação e uso sustentável dos recursos naturais do bioma sejam atingidos (MMA, 2011). As diretrizes da publicação têm como foco a relação com a imprensa para a valorização e conservação do bioma. De acordo com o texto do guia, é essencial o envolvimento dos órgãos de Estado com a articulação com entidades e organizações não governamentais relacionadas à biodiversidade e associações de rádio e televisão. Para além dessas mídias, o documento chama atenção para que o ministério apoie "a produção e divulgação de documentários, livros, CDs, exposições, entre outras manifestações" (MMA, op. cit., p.9).

Conforme o portal do MMA, em 2016 tramitou no senado o projeto que institui a Política de Desenvolvimento Sustentável da Caatinga (PLS 222/2016), sendo esta aprovada na Comissão de Desenvolvimento Regional, seguindo para a análise de outras comissões (MMA, 2017c).

No que se refere aos textos introdutórios das publicações levantadas, bem como o texto disponível no portal do MMA, as informações gerais sobre o bioma são: área de cobertura do Caatinga no país; importância dos aspectos sociais, com ênfase para a dependência econômica da população quanto aos recursos naturais; dados sobre riqueza, geralmente com o número de espécies, e destaque para o alto grau de endemismo do bioma; perda de biodiversidade devido à sobre-exploração dos recursos naturais; e medidas existentes para a conservação da Caatinga, sobretudo a criação de UCs.

Em relação ao Bioma do Cerrado, destacamos a instituição do Núcleo dos Biomas Cerrado e Pantanal (NCP), ocorrida em 2004 pelo MMA, com vistas à articulação de iniciativas para a conservação e uso sustentável dos recursos desses biomas. 0 núcleo tinha também como prioridade, apoiar a Comissão Nacional do Programa Cerrado Sustentável. A comissão por sua vez tem como objetivo acompanhar a implementação de políticas públicas de meio ambiente no que se refere ao bioma do Cerrado. O Programa Nacional de Conservação e Uso 
Sustentável do Bioma Cerrado - Programa Cerrado Sustentável, foi instituído em 2005 com o objetivo "promover a conservação, a restauração, a recuperação e o manejo sustentável de ecossistemas do bioma Cerrado, bem como a valorização e o reconhecimento de suas populações tradicionais" (BRASIL, Decreto no. 5.577, 2005. Art. 1). Para alcançar seus objetivos, o documento do programa destaca diversas linhas de ação, dentre as quais não são mencionadas atividades relacionadas à divulgação ou educação.

No âmbito do programa, foi criada a rede de Cooperação em Ciência e Tecnologia para a Conservação e o Uso Sustentável do Cerrado (ComCerrado). A ação contou com a participação do MCTI, MMA, representantes de instituições de ensino e pesquisa e organizações não-governamentais com atuação no bioma. A ComCerrado, à semelhança das redes constituídas nos diferentes biomas brasileiros, é uma rede destinada à produção de conhecimento sobre a biodiversidade e sobre questões socioeconômicas das populações que habitam áreas do bioma. No "Plano Científico" da rede (2009-2016) ${ }^{32}$, para além de promover a integração entre grupos e instituições de pesquisa e ensino com atuação no Cerrado, são objetivos da rede avaliar e mapear a biodiversidade e desenvolver o aproveitamento biotecnológico e de uso sustentável dela, visando a conservação do bioma e o desenvolvimento das regiões de cerrado. Além disso, estão entre os objetivos a organização e disponibilização do conhecimento científico e tecnológico.

Dentre as publicações oficiais, disponibilizadas no portal do MMA, encontramos a proposta do Programa Cerrado Sustentável de 2003, além de publicações sobre os temas: biodiversidade do bioma, a prevenção de queimadas e desmatamento, entre outros. Não encontramos materiais do ministério com diretrizes para a divulgação de conhecimento e educação para a conservação do Cerrado.

Tanto nas publicações levantadas sobre o bioma, quanto no portal do MMA, os textos introdutórios trazem informações sobre a área de cobertura do Cerrado no país, citam a existência de fitofisonomias, apresentam dados sobre

\footnotetext{
32 O Plano Científico da Rede de pesquisa de conservação e uso sustentável do Cerrado (2009-2016) está disponível em <http://conservacao.bio.br/comcerrado/images/plano\%20cientfico-verso\%2028-092009.pdf> Acesso em 03 mar. 2017.
} 
riqueza geralmente com o número de espécies, abordam a importância dos aspectos sociais, enfatizam a perda de biodiversidade com ênfase para as queimadas, além de enunciar algumas das medidas existentes para a sua conservação.

A análise das políticas oficiais e textos sobre os biomas mostra que há uma diversidade de programas coordenados ou vinculados às agências em âmbito federal. Ainda que o foco desta análise não inclua um levantamento exaustivo dos programas e textos oficiais sobre os biomas, notamos que a diversidade de programas identificados implica no entanto, em uma pulverização de ações em várias frentes, mostrando uma fragilidade tanto nas ações de educação e divulgação mais ampla dos conhecimentos produzidos, quanto nas sínteses que permitam ter uma visão geral do que foi produzido nos diferentes programas e avaliar as ações futuras.

\subsection{O Campo Recontextualizador Pedagógico dos museus}

Conforme aponta Bernstein (1996), há três contextos centrais relacionados ao discurso, prática e organização educacional. 0 contexto primário é aquele no qual um determinado texto é inicialmente desenvolvido e posicionado, dessa forma, esse contexto está ligado à geração do discurso e de suas práticas. Nesse contexto, distinguimos o campo da economia, do controle simbólico e do Estado. Já o contexto secundário está relacionado à reprodução seletiva do discurso pedagógico, abrangendo os espaços e situações educacionais em que ocorre o processo de transmissão-aquisição dos discursos. Os movimentos de textos e práticas do contexto primário para o secundário, ou seja, a relocação do discurso é regulada pelos agentes e agências que atuam em um terceiro contexto, no qual se distinguem os campos recontextualizadores oficial e pedagógico.

No início do capítulo, discutimos a conformação do campo de recontextualização oficial (CRO) dos museus, e agora, na sequência, nos deteremos aos agentes, agências, textos e práticas que compõem o campo de recontextualização pedagógica (CRP) responsável pela seleção, refocalização e relocação dos discursos para o contexto de reprodução, ou seja, as exposições. 
Atuam enquanto agentes no CRP, segundo Bernstein (op.cit.), os docentes das universidades e institutos de pesquisa, educadores do ensino formal e não formal. Entre as agências, constituem o CRP, as faculdades de educação e institutos de pesquisa em educação (públicos ou privados), e fundações, dentre outras. Esses agentes e agências atuam na recontextualização do discurso pedagógico oficial na passagem desse discurso para o contexto de reprodução. Vale destacar no entanto, que os processos de recontextualização dos discursos gerados no contexto primário, não envolvem necessariamente, a atuação dos dois campos de recontextualização (CRO e CRP), podendo haver apenas um campo recontextualizador. Isso pode ocorrer por exemplo, quando os agentes que geram os discursos atuam também como seus recontextualizadores. Para Bernstein (op. cit.) esses casos são exceções nos processos de recontextualização e justamente por isso, é importante estudá-los.

De acordo com Martins (2011), é possível notar no Brasil nos últimos 15 anos um crescimento do campo recontextualizador pedagógico (CRP) dos museus. Isso se deve à ampliação da importância da educação entre as funções sociais dos museus, com uma maior estruturação de setores educativos nos museus brasileiros a partir da década de 1960. No caso dos jardins botânicos, conforme Souza (2009), esses espaços passaram a contar com ações educativas destinadas à formação de professores e para o público escolar, justamente a partir desse período. Segundo os dados do Cadastro Nacional de Museus de 2010, dentre as 3025 instituições cadastradas, cerca de $80 \%$ delas realizavam visitas guiadas junto ao público em geral e metade dos museus declararam possuir setor ou divisão educativa (IBRAM, 2011).

Relacionado à ampliação do CRP dos museus, nota-se ainda a estruturação de associações com atuação específica na educação em museus. Conforme destaca Martins (op. cit.), a associação mais antiga e com grande influência na área é o Comitê Internacional para Educação e Ação Cultural do Conselho Internacional de Museus (CECA-ICOM) ${ }^{33}$, um dos cinco comitês permanentes do ICOM. O comitê possui como objetivos o intercâmbio internacional de informações e ideias sobre a educação em museus e a legitimação da educação

\footnotetext{
${ }^{33}$ O ICOM - Conselho Internacional de Museus (sigla em Inglês), é uma Organização não-governamental que mantém relações formais com a UNESCO, executando parte do programa dessa para museus. Possui atualmente mais de 35000 membros e agrega 172 comitês.
} 
em museus como parte da política e dos programas do ICOM, além de estabelecer diretrizes e parâmetros para a profissionalização da área. Participam do CECA profissionais de museus, de variadas tipologias, especialistas ou interessados em educação museal. 0 comitê possui mais de 1000 membros em 85 países, sendo atualmente presidido por uma brasileira, profissional de museu ${ }^{34}$. O CECA é responsável também pela publicação da revista ICOM Education (Icom Educação).

Um aspecto que merece destaque na atuação do CECA é a realização de reuniões anuais, com a participação dos comitês dos diversos países. O CECABrasil vem participando desses encontros, com a produção e apresentação de texto produzido a partir do tema lançado pelo comitê internacional. Segundo Studart (2004), um aspecto importante da redação desse texto é a forma colaborativa como ocorre, sendo redigido por diferentes membros do comitê brasileiro, representando assim, um esforço de associação entre os profissionais e outros interessados na área de educação em museus, contribuindo para uma reflexão participativa sobre os temas.

Outro tipo de associação relacionada à educação em museus no Brasil são as Redes de Educadores em Museus (REMs) ${ }^{35}$, que conforme dissemos anteriormente, vêm atuando na definição do Programa Nacional de Educação Museal (PNEM) junto ao Ibram. Atualmente existem mais de dez redes no país (RJ, CE, DF, PE, GO, SC, RS, BA, PB, MT, CE, SP, MA, Região da Vertentes). A primeira rede foi criada no Rio de Janeiro em 2003 em uma iniciativa de criação de uma rede local e nacional. Grande parte das REMs surgiram no final da década de 2000 e início da de 2010. Essas redes têm como objetivos a promoção de encontros entre educadores de museus e instituições congêneres, para a reflexão sobre as práticas profissionais, compartilhamento de ideias e constituição de grupos de trabalho e estudos na área. As REMs nos diferentes estados e regiões

\footnotetext{
${ }^{34}$ As informações sobre os diferentes comitês do ICOM e suas estruturas administrativas podem ser encontradas em <http://icom.museum/the-committees/international-committees/internationalcommittee/international-committee-for-education-and-cultural-action/htm> Acesso em: 19 abr. 2017).

35 Há uma REM nacional com as quais as regionais são ligadas, porém essas possuem funcionamento independente. As redes adotam nomenclaturas diferentes sendo a mais comum Rede de Educadores em Museus e Centros Culturais, há no entanto variações como por exemplo, a Rede de Educadores em Museus e Instituições Culturais (REMIC-DF e REMIC-PE) e a Rede de Educadores em Museus e Patrimônio (REMP MT).
} 
promovem encontros periódicos, havendo ainda os Encontros Nacionais da Rede de Educadores em Museus (EREM).

No contexto dos jardins botânicos, destacamos a organização Botanic Gardens Conservation International (BGCI) que representa uma rede de 500 jardins botânicos em mais de 100 países, constituindo a maior rede internacional de conservação de plantas. Para além de incentivar a coleta, conservação, documentação e cultivo de amostras de plantas no mundo todo, a organização atua de modo a propiciar o compartilhamento de informações entre as instituições, coordena projetos de formação, educação e práticas para a conservação e ainda na mobilização de recursos financeiros para o desenvolvimento desses projetos. Além disso, a BGCI é responsável pela publicação do BG journal e da revista Roots.

Na área de educação em jardins botânicos, a BGCI atua por meio do desenvolvimento de diretrizes e ferramentas para a ampliação e qualificação das práticas em educação ambiental e educação para o desenvolvimento sustentável. Uma importante contribuição da organização é a publicação das diretrizes para as ações em Jardins botânicos (WILLISON, 2006), referência para a área de educação nesses espaços no mundo todo.

A organização possui um centro de recursos educacionais, que tem entre suas ações a publicação da revista Roots - The education review for botanic gardens, na qual são abordados temas como formação de professores, interpretação ambiental, pesquisa e educação para a sustentabilidade, entre outros. Além disso, foram produzidos pela BGCI, sites para auxiliar os jardins na implantação de recursos de interpretação ambiental e para o desenvolvimento de biocombustíveis em pequena escala com o envolvimento de saberes locais. 0 portal da organização na internet disponibiliza também materiais educativos como livros, jogos e planos de aula.

A BGCI organiza ainda congressos internacionais sobre educação em jardins botânicos, realiza programas de formação, desenvolve planos de educação e interpretação e efetua avaliações de programas de educação. Além disso, financia em parceria com instituições públicas e privadas, projetos de educação nos jardins da rede. 
No âmbito nacional, citamos a associação Rede Brasileira de Jardins Botânicos (RBJB), fundada em 1991, agrega atualmente 46 instituições. A rede tem como objetivos incentivar a cooperação entre os jardins botânicos brasileiros, estimular a conservação de espécies, ampliar o papel dos jardins na conservação da biodiversidade, incentivar as ações de educação ambiental, fomentar e facilitar a criação e implantação de jardins botânicos, auxiliar os jardins botânicos na implementação das diretrizes e ações de acordo com os objetivos dessas instituições definidos por meio da resolução ${ }^{36}$ do Conselho Nacional do Meio Ambiente (CONAMA) do MMA.

Destacamos que tanto o BGCI quanto a RBJB e ainda o ICOM, atuam no campo recontextualizador pedagógico na medida em que transformam os discursos oficiais gerando o discurso pedagógico de reprodução, mas os agentes dessas instituições podem também atuar no campo de recontextualização oficial. As próprias agências têm influencia sobre o CRO, uma vez que acabam por balizar diretrizes para implementação das políticas públicas, por exemplo.

Ainda no que concerne a ampliação do CRP dos museus, levando em consideração que nesse campo atuam agências tais como as universidades, faculdades e departamentos de educação (BERNSTEIN, 1996), citamos o aumento do número de cursos de formação específicos para a área museal e em educação em museus, vinculados e promovidos por diferentes agências públicas ou privadas. No que diz respeito à formação de nível superior e acadêmica, destacamos que não há um curso específico para a formação de educadores de museus, mas sim cursos que abordam em maior ou menor grau os conteúdos específicos da área. São eles os programas de pós-graduação (Museologia e Patrimônio - Unirio/MAST; Museologia-UFBA; Interunidades em MuseologiaUSP; Museologia e Curadoria-Belas Artes), cursos de graduação em museologia (UFBA, UFRB, UNB, UFG, UFMG, UFOP, UFPA, UFPe, UNIRIO, CCH/Escola de Museologia-RS, UFPel, UFRGS, UFSC, UFS) e especializações (Especialização em Museologia do Museu de Arqueologia e Etnologia da USP, Ensino à distância do Sistema Estadual de Museus -SISEM da Secretaria de Estado da Cultura). Há também os cursos de formação específicos da área de educação em museus promovidos pelas próprias instituições museais, voltados para os profissionais

\footnotetext{
${ }^{36}$ Resolução CONAMA número 266, de 03 de agosto de 2000.
} 
que atuam na área e os cursos de formação com professores. E por fim, há cursos oferecidos pelas secretarias de cultura.

No que se refere às publicações brasileiras voltadas aos profissionais da área de educação museal, é possível localizar uma produção mais ampla a partir do início do século XXI. O Museu da Vida da Fundação Oswaldo Cruz produz diversas publicações que são referências para a área de educação em museus, dentre elas destacam-se os Cadernos do Museu da Vida, publicados a partir de 2002, diversos livros sobre educação em museus de ciências e divulgação científica, além dos relatórios das pesquisas do Observatório de Museus e Centros Culturais (OMCC) e do Observatório de Museus e Centros de Ciência \& Tecnologia (OMCC\&T) ${ }^{37}$. No site do Grupo de Estudo e Pesquisa em Educação Não formal e divulgação Científica (GEENF) há mais de dez títulos voltados à profissionais, estudantes e outros interessados na área de educação em museus e divulgação da ciência, todos publicados a partir de 2001. Destacamos ainda as referências voltadas para profissionais da área levantadas por Valle (2014), que inclui livros, cadernos de mediação, vídeos e canais do youtube, produzidos nos últimos sete anos. Há ainda diversas publicações como a revista "Musas" (IBRAM), "Museologia e Patrimônio" (MAST/MCTIC), "Série Museologia" (EDUSP), entre outras que contam com edições especiais sobre educação em museus.

Quanto à constituição do CRP dos museus, a análise dos setores educativos de diferentes tipologias de museus realizada por Martins (2011), mostrou importante protagonismo dos educadores das instituições, na medida que são eles os responsáveis pela produção do discurso pedagógico. Segundo a autora "em todos os museus estudados eles são os propositores das ações educacionais, principalmente no que se refere aos objetivos e métodos empregados nessas práticas" (MARTINS, op. cit., p. 357). No entanto, a autora

\footnotetext{
37 O Observatório de Museus e Centros de Ciência e Tecnologia (OMCC\&T) foi criado após a extinção do Observatório de Museus e Centros Culturais (OMCC) em 2012. Participam da nova constituição: a Fundação Planetário do Rio de Janeiro (Prefeitura da Cidade do Rio de Janeiro), o Museu Aeroespacial (Ministério da Defesa/ Força Aérea Brasileira), o Museu da Vida (Ministério da Saúde/Fundação Oswaldo Cruz), o Museu de Astronomia e Ciências Afins (Ministério da Ciência, Tecnologia e Inovação /MCTI) e o Museu Nacional (Ministério da Educação /UFRJ). Entre os objetivos do observatório, está a organização de uma rede de compartilhamento de conhecimentos sobre a divulgação da ciência (http://www.fiocruz.br/omcc/cgi/cgilua.exe/sys/start.htm?tpl=home. Acesso em: 13 mar 2017).
} 
afirma que o posicionamento desses agentes não é igual nos diferentes museus estudados, mostrando que a inserção da educação nas instituições apresenta controvérsias. Nesse sentido, há a compreensão de que as principais formas de relação dos museus com os seus públicos podem até mesmo não envolver os setores educativos. Além disso, a autora ressalta que o posicionamento hierárquico entre os setores e as funções institucionais leva ao predomínio de determinados discursos nas mensagens pedagógicas das ações educativas. É o caso, por exemplo, dos museus de ciências, nos quais o discurso científico tem maior estatuto que os demais.

Esse último aspecto é destacado também na investigação empreendida por Marandino (2001, 2015) em diferentes exposições de museus de ciências. Segundo a autora, o contexto histórico e político, assim como a divisão de trabalho nas instituições, influenciam no poder que os diferentes setores e agentes possuem na produção do discurso expositivo. Nas diferentes exposições, conforme indica a autora, além dos especialistas das áreas científicas específicas, educadores e museólogos participaram como agentes no processo de produção do discurso expositivo final, "tendo maior ou menor poder de decisão em função da autonomia que a instituição propiciou a cada um deles para a realização do trabalho" (MARANDINO, 2015, p. 709).

\subsection{O processo de recontextualização dos discursos expositivos}

Os discursos expositivos presentes na "Estufa do Cerrado" do JB de SP e na "Estufa da Caatinga" da FZB de BH são resultados de processos de recontextualização dos quais participaram diferentes agentes e agências. Como dito anteriormente, os indivíduos e instituições que participam da recontextualização dos discursos atuam na seleção de conteúdos e na forma de sua transmissão, portanto atuam sobre o "que" e o "como" do discurso. Conforme ressaltamos, a ação desses agentes depende do posicionamento deles junto às agências envolvidas na produção dos discursos e em relação aos demais agentes. Há ainda que se considerar as relações da(s) agência(s) ligada(s) à produção dos discursos com outras agências e com os campos externos. Além disso, é preciso 
levar em conta a influência do contexto de reprodução dos discursos nesse processo.

A seguir buscamos descrever detalhadamente os processos de produção das exposições, utilizando para tal os dados de entrevistas realizadas com os conceptores, documentos e observações das exposições. Ao longo desta explanação, procuramos também relacionar as características do processo com os textos e contextos recontextualizadores.

Como foi dito no capítulo 2, a exposição de longa duração "Estufa da Caatinga Mineira” está situada na Fundação Zoo-botânica de Belo Horizonte (FZB-BH), instituição de administração indireta da prefeitura da cidade de Belo Horizonte (MG), estando vinculada à Secretaria Municipal de Meio Ambiente. 0 tema central dessa exposição é o bioma da Caatinga, em especial aquela existente no estado de Minas Gerais. 0 projeto de produção da exposição teve início em 2003 e a exposição foi inaugurada em 2004. Já a "Estufa do Cerrado" está presente no Jardim Botânico de São Paulo/Instituto de Botânica da Secretaria de Estado do Meio Ambiente. 0 jardim e o instituto estão situados dentro do Parque Estadual das Fontes do Ipiranga (PEFI), no município de São Paulo. 0 bioma do Cerrado é tema central da exposição, inaugurada em 2012.

Um primeiro aspecto importante a ser ressaltado nesta análise é que ambas exposições estão sediadas em jardins botânicos. Conforme destacamos anteriormente, tais instituições são consideradas museus, que possuem como peculiaridade ter coleções vivas. Os jardins botânicos são instituições que, desde sua origem, têm como missão a conservação, estudo e documentação de espécies vegetais. A ampliação do relacionamento dos jardins com seus públicos vem ocorrendo paulatinamente desde o século XVIII, e de forma mais acentuada na metade do século passado, com a estruturação de atividades educativas e criação de setores específicos (SOUZA e MARANDINO, 2012). Com o aumento da importância das questões ambientais na década de 1970, essas instituições, assim como as unidades de conservação abertas ao público e os zoológicos, passaram a assumir papel estratégico na educação para a conservação do meio ambiente e da biodiversidade e na educação para o desenvolvimento sustentável, abrigadas geralmente, sob a denominação de educação ambiental. 
No contexto nacional, os jardins botânicos estão vinculados às universidades públicas (e.g. Jardim Botânico de Botucatu, Jardim Botânico da Universidade Federal de Mato Grosso, o Jardim Botânico da Universidade Federal Rural do Rio de Janeiro), aos institutos de pesquisa ou fundações de governo (Jardim Botânico do Rio de Janeiro, Jardim Botânico de São Paulo, Jardim Botânico do Instituto Agronômico - Campinas, Fundação Zoo-botânica de Belo-horizonte, Fundação Zoo-botânica de Porto Alegre), além dos diversos jardins e hortos municipais.

De acordo com a resolução do Conselho Nacional do Meio Ambiente (CONAMA), são considerados jardins botânicos as áreas protegidas que possuem "coleções de plantas vivas cientificamente reconhecidas, organizadas, documentadas e identificadas" (CONAMA, Resolução no. 339, 2003. Art. 1). Dentre as finalidades dessas instituições, a resolução destaca a importância desses espaços para a educação, cultura, lazer e conservação do meio ambiente. A resolução normatiza ainda a criação e funcionamento dos jardins botânicos, estabelecendo um Sistema Nacional de Registro de Jardins Botânicos (SNRJB), ligado ao Jardim Botânico do Rio de Janeiro (JBRJ).

A história do Jardim Botânico de São Paulo está ligada ao processo de desapropriação de áreas de manancial pela Repartição de Águas do Estado, ainda no século XIX. A área contém as nascentes do riacho Ipiranga, e ficou conhecida por Parque da Água Funda ou Parque do Estado, atualmente denominada Parque Estadual das Fontes do Ipiranga.

De acordo com Rocha e Cavalheiro (2001), a função de captação de água foi abandonada em 1928 e a área ficou sob a gestão da Seção de Botânica do Instituto Biológico. Uma primeira proposta de ocupação do espaço foi a criação de um parque público, que nunca chegou a ser criado. Em seguida houve a iniciativa de organizar um jardim botânico com objetivos recreativos e para a produção e exposição de plantas ornamentais. 0 início da implementação do Jardim Botânico de São Paulo (JBSP) incluiu a abertura de caminhos, ruas e avenidas, estruturação do Jardim de Lineu e do Orquidário do Estado, além da construção de duas estufas.

De acordo com Hoehne (1940), o JBSP foi fundado oficialmente em 1938, sendo também criado o Departamento de Botânica do Estado ligados à Secretaria 
de Agricultura, Indústria e Comércio. Em 1942 o departamento passou a denominar-se Instituto de Botânica e em 1987, sua administração foi transferida para a Secretaria do Meio Ambiente. Atualmente o instituto inclui em sua estrutura, além do JBSP, duas unidades de conservação: as reservas de MogiGuaçu (Cerrado) e Paranapiacaba (Mata Atlântica). O portal do jardim na internet apresenta como missão da instituição "a preservação e o uso sustentável da biodiversidade paulista e brasileira, por meio da conservação in-situ e ex-situ, e o conhecimento de todos os grupos de plantas e fungos, bem como de suas relações com o meio ambiente" (JBSP, 2017). 0 jardim possui um Núcleo de Pesquisa em Educação para Conservação, responsável por ações educativas e pesquisas na área de educação ambiental.

O Jardim Botânico de Belo Horizonte foi criado em 1991 como um departamento da Fundação Zoo-Botânica de Belo Horizonte (FZB-BH) e funcionou até o ano de 2000 em outra região da cidade, até ser transferido para a localização atual no bairro da Pampulha, dividindo a área com o Jardim Zoológico. Em 2001 sua atual estrutura foi inaugurada, incluindo lagos com espécies aquáticas, estufas e jardins temáticos.

Além do jardim botânico e zoológico a estrutura da FZB-BH inclui o Parque Ecológico da Pampulha (figura 3.3), que tem administração realizada pelo Departamento de Educação Ambiental e Gestão do Parque Ecológico. Esse departamento gere também os programas educativos do jardim botânico e zoológico, por meio do Serviço de Educação Ambiental (SEA). A fundação tem entre suas missões "contribuir para a conservação da natureza realizando ações de educação, pesquisa e lazer, que sensibilizem as pessoas para o respeito à vida" (FZB-BH, 2017). 

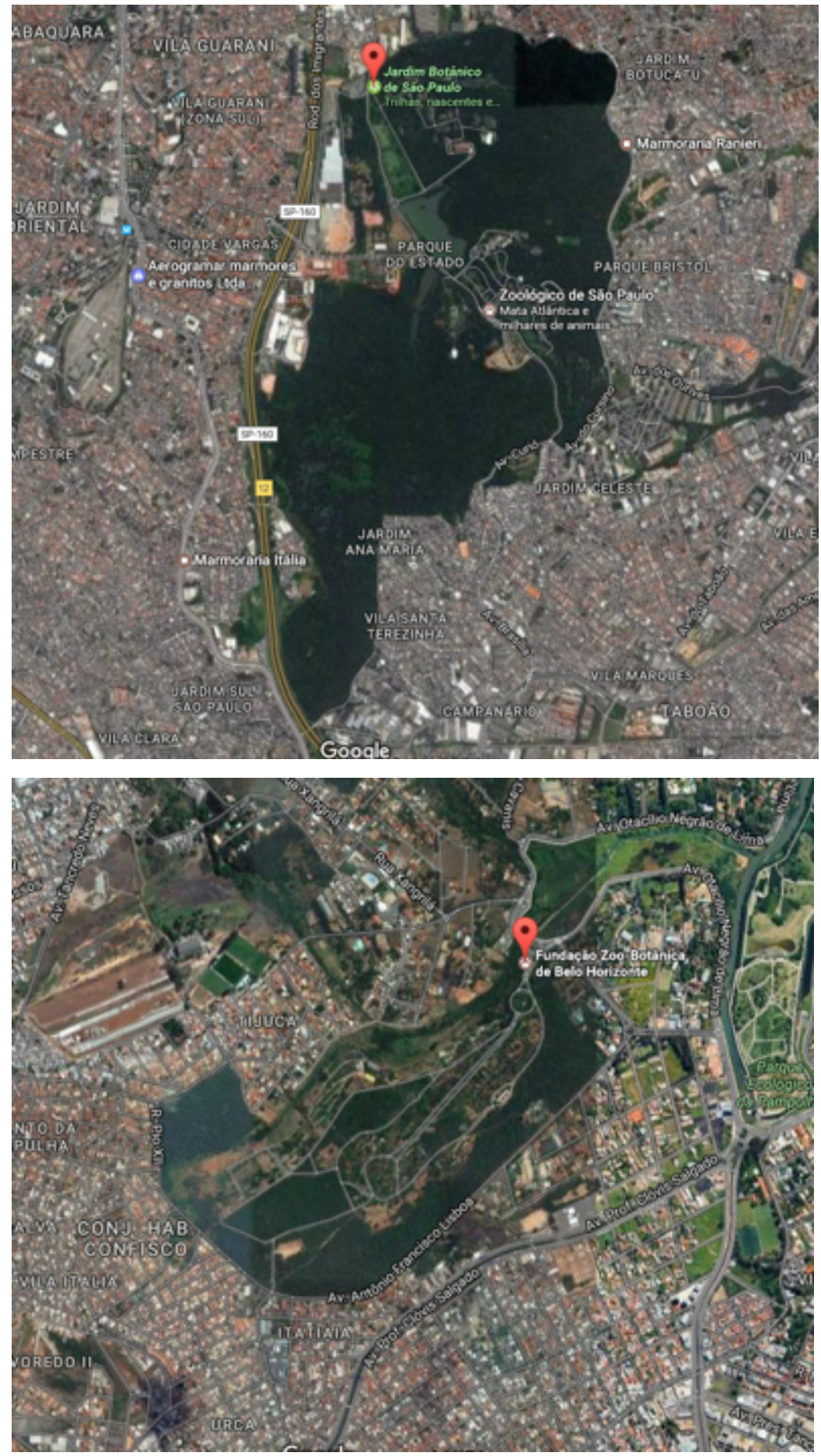

Figura 3.3: Imagens de satélite disponíveis na plataforma do Google Maps com a localização do Jardim Botânico de São Paulo e Fundação Zoo-Botânica de Belo Horizonte

Nota-se pela descrição, que as exposições estão sediadas em jardins botânicos de administração pública, direta e indireta, com missões relacionadas à conservação da biodiversidade, incluindo o papel da educação para essa finalidade. Por conta do vínculo com as esferas governamentais, essas instituições constituem importantes estruturas para a implementação das 
políticas públicas relacionadas à conservação do meio ambiente e desenvolvimento sustentável.

\subsubsection{Concepção inicial e a captação de recursos}

Como expressa o nome das exposições, ambas ocupam as estufas dos jardins botânicos. Com foi dito anteriormente, o JBSP possui duas estufas, símbolos do jardim, inauguradas em 1930 com uma grande exposição de orquídeas e são, conjuntamente com os lagos, alguns caminhos e o jardim de Lineu, o embrião do Jardim Botânico inaugurado em 1938 (TEIXEIRA 1988). Mais recentemente, uma das estufas estava aberta para o público com espécies da mata atlântica e a outra, hoje ocupada pela exposição em análise, era utilizada para exposições temporárias.

Já o jardim da FZB-BH conta com 5 estufas interligadas por recantos, sendo uma central e outras duas saindo de cada lado dessa. As estufas foram criadas inicialmente para a exposição de espécies de grupos específicos, como violetas, suculentas, cactáceas, o que segundo o entrevistado CAA1 mostrava uma concepção antiga de jardim botânico. Atualmente as estufas apresentam exposições de imersão que representam biomas e fisionomias brasileiras presentes em Minas Gerais, como a Mata Atlântica, Caatinga e Campo Rupestre. As outras duas estufas são dedicadas à evolução das plantas.

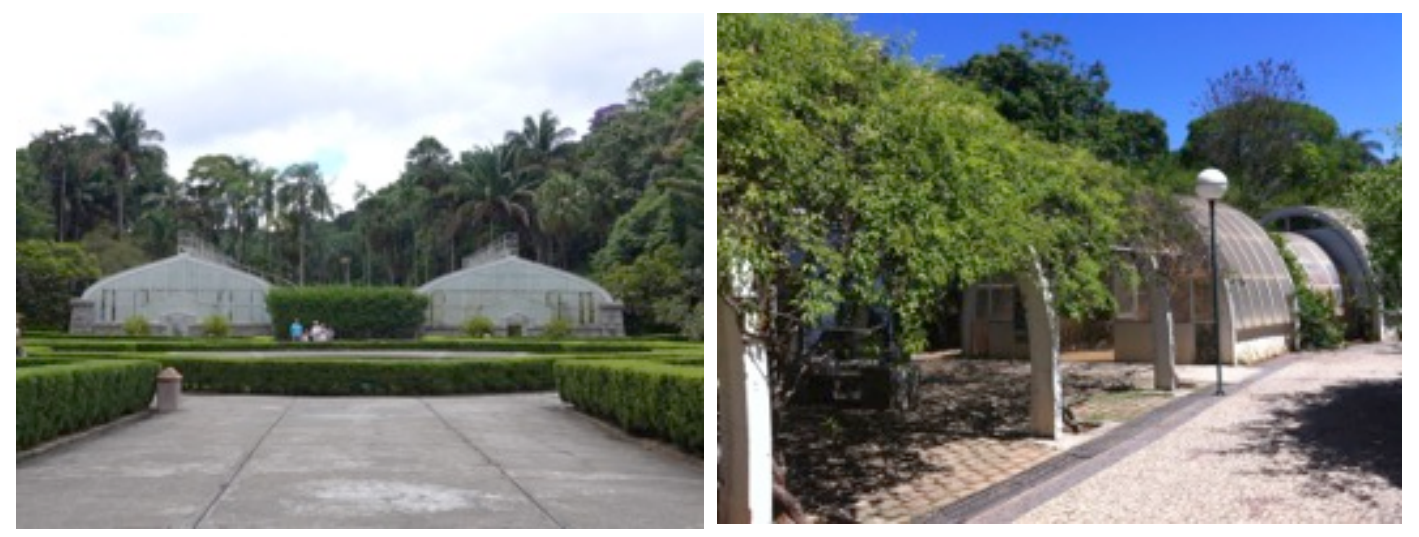

Figura 3.4: As estufas do Jardim Botânico de São Paulo, à esquerda, e da Fundação Zoo-Botânica de Belo Horizonte, à direita. 
O conceito inicial de utilizar as estufas da FZB-BH para representar os biomas surgiu entre as equipes do jardim botânico e do SEA, que identificaram nessa ideia um uso mais apropriado dessas estruturas para as missões do jardim. De acordo com CAA2 e CAA3, a partir dos projetos e implementação das estufas, que seguiram uma concepção imersiva de exposição, o jardim tornou-se um referência na RBJB, uma vez que esse tipo de exposição ainda não estava presente nos jardins botânicos do país.

Essa coisa é muito só isso mesmo, porque todos os Jardins, eles têm aquelas coleções, é, de bromélia, orquídeas, cacto e suculentas, e tal. (...)

E a gente mudou isso. Nas reuniões da Rede, a gente era um pouco assim, era assim uma referência.

(...) Um referencial dos biomas, de representar biomas, até seguindo as estratégias para a conservação. (CAA3)

Foi também a ideia de representar de "forma diferente" o bioma cerrado que levou à iniciativa de desenvolvimento da "Estufa do Cerrado". De acordo com CER1, havia uma vontade pessoal de revitalizar as estufas do Jardim Botânico de São Paulo. Para CER1, a estufa que abrigava exposições temporárias estava subutilizada, e como um cartão postal do jardim, tinha enorme potencial para uma exposição que levasse o público a conhecer o Cerrado.

A utilização de estufas resolve também a questão técnica de manutenção de um ambiente adequado para a vegetação, além de possibilitar a utilização de recursos que dificilmente poderiam ser empregados nos ambientes abertos dos jardins. 0 ponto central para os conceptores de ambas as exposições era desenvolver uma exposição em que os visitantes pudessem se sentir no ambiente representado e obter informações sobre esse bioma de forma estimulante. Também, em ambos os casos, a ideia de conceber uma exposição de imersão surgiu de experiências de visita realizadas pelos conceptores (CER1, CER2 e CAA1) em jardins botânicos de outros países. No que se refere à exposição "Estufa da Caatinga", CCA1 relata que foi no estágio realizado no Kew Gardens (Inglaterra) que ela conheceu mais a fundo as possibilidades de aplicação dos recursos presentes em exposições de imersão, gerando diversas ideias para as representações dos biomas nas estufas do jardim da FZB-BH.

Para CER1 e CER2, as visitas técnicas em diversos jardins botânicos foram os embriões da proposta de desenvolver uma exposição "mais moderna" sobre 
os ambientes. Em especial, esses conceptores citaram o Eden Project (Inglaterra) que apresenta diversas estufas com a representação de diferentes biomas do mundo. Chamou também a atenção dos conceptores, o uso educacional das diversas instalações e das áreas abertas do jardim. Estimulados com as possibilidades oferecidas por esse tipo de exposição, iniciaram a busca por financiamento e parcerias.

Para CER1, CAA1 e CAA2, a escolha por fazer uma exposição de imersão está ligada também às possibilidades desse tipo de espaço para facilitação do aprendizado, uma vez que permite ao visitante imergir em um determinado ambiente que talvez nunca tenha oportunidade de visitar, aliando ainda informações em suportes variados e objetos. De acordo com Bitgood (1990), avaliações realizadas com o público em museus com exposições imersivas mostram a importância da imersão na experiência do visitante, tanto no que se refere ao conhecimento declarativo e relacionado aos procedimentos $\mathrm{e}$ habilidades, como aquele ligado à dimensão afetiva e emocional.

Essa foi a ideia de CER1. Fazer uma coisa nova dentro do Botânico e não aquela coisa de museu estático. E a outra coisa é criar uma dinâmica que seja interessante pra diferentes idades. E que a pessoa consiga ficar na exposição. E que a pessoa possa passar e ficar ali na exposição e guardar informação que não seja só pelo texto. Atrair mais visitantes. (CER3)

(...) o Cerrado é tão pouco conhecido, principalmente em São Paulo. Você fala de Cerrado em Goias é uma coisa, mas falar de Cerrado em São Paulo é outra, pouca gente conhece, já visitou, tem interesse e tal. Então seria uma forma também de torná-lo mais conhecido e atrair mais visitantes e tal, porque o Jardim Botânico precisa ter visitação. Então foi essa a ideia. (CER1)

Nota-se que o conceito das exposições já trazia conteúdo (apresentação dos biomas brasileiros) e forma (exposição de imersão) bastante idealizados pelos conceptores que participaram desde o início do processo de produção do discurso expositivo. Como mencionado anteriormente, a ideia de produzir a exposição "Estufa do Cerrado" surgiu entre CER1 e CER2, para os quais há em São Paulo uma menor ênfase nas ações de divulgação e educação sobre o bioma do Cerrado em relação à Mata Atlântica. 0 Cerrado é o segundo maior bioma 
brasileiro em sua extensão, cuja cobertura original era de quase $24 \%$ da área do país. Em São Paulo, o bioma cobria originalmente cerca de 33\% do estado (MMA, 2015). Na cidade de São Paulo ocorriam os Campos-Cerrados, presentes por exemplo, na região do Campo Belo, Perdizes e no Butantã (CARDIM, 2014). Atualmente, resquícios desses campos ainda existem espalhados na cidade. No Butantã há o Parque Municipal Ecológico de Campo-Cerrado Dr. Alfred Usteri, dedicado à conservação e recuperação da vegetação campestre (SENA, 2010).

Ambos conceptores que estiveram envolvidos na elaboração do conceito inicial da exposição "Estufa do Cerrado" (CER1 e CER2), atuavam como pesquisadores especialistas em Botânica e Ecologia do Cerrado, respectivamente. À época da concepção da exposição, CER1 era pesquisadora científica do Instituto de Botânica e esteve à frente do projeto e implementação da exposição junto à instituição. CER2 foi docente do Instituto de Biociências da Universidade de São Paulo e participou como consultor de conteúdos, especialmente de ecologia do Cerrado. Ainda de acordo com CER1, tanto durante a fase de concepção e captação de verbas, quanto nas fases posteriores, as ideias, projetos e outras informações eram reportadas à diretoria do Instituto.

A partir do conceito inicial, CER1 começou a desenvolver um projeto para a captação de recursos. Segundo a pesquisadora, uma das ideias iniciais foi pedir a verba junto ao programa FAPESP de Pesquisas em Caracterização, Conservação, Restauração e Uso Sustentável da Biodiversidade (BIOTA-FAPESP).

Vale destacar que o programa, lançado em Março de 1999, tinha como principais objetivos fazer um mapeamento do conhecimento da biodiversidade do estado de São Paulo, explorar possibilidades de uso sustentável de recursos naturais, subsidiar políticas de conservação e apoiar ações de divulgação e educação sobre temas relacionados com a biodiversidade. Desde de sua concepção, o BIOTA-FAPESP teve assim uma preocupação em fomentar ações educativas, principalmente voltadas para professores de segundo grau (SPEGLICH, 2009). Apesar dessa ser uma meta do programa, não havia uma exigência formal para que os projetos que fizessem parte do programa tivessem atividades ou produtos voltados à educação ou divulgação da biodiversidade. Em 2009 foram elaboradas as metas dos programa para os próximos 10 anos (JOLY et al., 2010). Neste plano, está clara a necessidade de manter o fluxo de 
informações aberto para o público mais amplo por meio de ações educativas, sejam elas de criação de museus virtuais, de atuação na educação formal e informal, desenvolvimento de programas voltados para a formação e atualização de professores da rede de ensino de segundo grau, divulgação dos resultados do programa na grande mídia, e criação de pesquisa em educação em biologia, educação e comunicação da biodiversidade. A partir de 2010, além dos projetos de "balcão", submetidos espontaneamente pelos pesquisadores, em temas definidos pelos proponentes, o Programa passa a lançar editais ou "chamadas" de pesquisa, de formar a direcionar o financiamento para demandas ou carências de pesquisa mais específicas, tendo aberto espaço para a apresentação de projetos de pesquisa em educação. Finalmente, concretizando uma demanda identificada no plano de ação de 2009, o programa lançou em 2015 uma chamada específica para educação: “Chamada de Propostas BIOTA/FAPESP: Educação"38.

Como o projeto não avançou junto ao programa BIOTA-FAPESP, pensouse em apresentar o projeto à Câmara de Compensação Ambiental da Secretaria do Meio Ambiente. Para tal, contatou-se uma organização social especializada em desenvolvimento de exposições, que elaborou uma proposta expositiva para captação de recursos. A análise dos documentos fornecidos pelos conceptores mostra que o estudo é datado de 2009 e incluía a justificativa conceitual, elaborada por CER1 e CER2, sugestões para instalações interativas, o programa educativo e a cenografia. Além da equipe de arquitetura e expografia, colaborou nesta etapa, via tal organização, uma consultora de conteúdo, especialista em Cerrado (CER3).

0 financiamento da exposição foi feito por meio de verbas de compensação ambiental devidas ao estado e sob deliberação da Câmara de Compensação Ambiental da Secretaria do Meio Ambiente do Estado de São Paulo, órgão ao qual o Instituto de Botânica (IBt) e o Jardim Botânico de São Paulo estão vinculados. 0 projeto foi apresentado à câmara por meio da representação do IBt nesse conselho.

\footnotetext{
38 Chamada de Propostas do Programa de Pesquisa em Caracterização, Conservação, Restauração e Uso Sustentável da Biodiversidade do Estado de São Paulo (BIOTA/FAPESP): Educação. Disponível em: <http://www.fapesp.br/9823>. Acesso em: 10 jan 2016.
} 
A Lei Federal no. 9985 (BRASIL, 2000a), conhecida como Sistema Nacional de Unidades de Conservação (SNUC), é o principal instrumento legal para definição e aplicação das compensações ambientais. Em seu artigo 36 é definido que todos os empreendimentos considerados de significativo impacto ambiental devem apoiar a implantação e manutenção de Unidades de Conservação, de acordo com diretrizes do Estudo de Impacto Ambiental (EIA/RIMA). Como o Parque Estadual Fontes do Ipiranga, no qual encontra-se o IBt e o JBSP, é uma UC, ela é passível de receber verbas de compensação. A Resolução CONAMA (2006) objetivou estabelecer diretrizes para o cálculo, cobrança, aplicação, aprovação e controle dos gastos oriundos da compensação ambiental. A resolução apresenta uma lista atividades, por grau de prioridade, para aplicação da verba de compensação ambiental. Nessa lista, a implantação de programas de educação ambiental consta como terceira atividade prioritária. Destaca-se ainda, que a normatização quanto à compensação ambiental abre a possibilidade de destinação de recursos de compensação ambiental para UCs de diferentes esferas, independentemente do licenciador ser municipal, estadual ou federal. 0 gerenciamento das compensações ambientais, em cada instância Federativa, ficou a cargo das Câmaras de Compensação Ambiental (BRASIL, 2002b).

Como contrapartida do IBt, para além da infraestrutura da estufa, foi disponibilizada mão-de-obra para reformas, coleta e plantio de espécies, auxílio de transporte, incluindo caminhões do Instituto Geológico e do Instituto Florestal. De acordo com CER1 "foi realmente, dentro da estrutura da Secretaria do Meio Ambiente, a gente teve bastante auxílio". A coleta de espécies também foi realizada na estrutura do IBt, principalmente da Reserva Biológica de MogiGuaçu. Já as plantas herbáceas foram obtidas por meio de excedentes de experimentos dos laboratórios de fisiologia e bioquímica do instituto.

O financiamento da "Estufa da Caatinga" da FZB/BH foi realizado por meio do "Prêmio Projetos Educacionais - Modelos nos Jardins Botânicos brasileiros" concedido pelo "Projeto Investindo na Natureza - Brasil", iniciativa do órgão internacional de jardins botânicos - Botanic Gardens Conservation International (BGCI), com apoio do banco HSBC. Como foi dito anteriormente, o BGCI é uma organização sem fins lucrativos que atua na formação de redes de 
jardins botânicos e financiamento de projetos para a conservação da biodiversidade vegetal.

Com intuito de proteger a biodiversidade e combater problemas ambientais, o HSBC iniciou em 2002 um aporte de recursos no escopo do "Projeto Investindo na Natureza". Essa iniciativa teve duração de cinco anos e contou com a parceria do BGCI, Fundo Mundial para a Natureza (WWF) e Earthwatch Institute. Foram financiados projetos em diversos países, para desenvolvimento e manutenção de banco de genes, programas de educação e projetos de revitalização e conservação de jardins (BGCI, 2017).

O objetivo do "Prêmio Projetos Educacionais - Modelos nos Jardins Botânicos brasileiros" era apoiar projetos de Educação para a Conservação em jardins botânicos brasileiros associados a RBJB. De acordo com CAA1, entre as diretrizes do programa, além das questões específicas relacionadas à educação para conservação, havia a necessidade de contribuir para a ampliação do conhecimento em botânica. Assim, o documento do projeto, fornecido pelos conceptores da exposição, destaca como objetivo geral do projeto a contribuição para a conservação do bioma por meio "de estudos botânicos e de um programa educativo que promova o seu conhecimento e estimule a valorização das espécies nele existentes, assim como de seus aspectos socioculturais" (ANDRADE, 2002, p.3). Vale destacar que o projeto, intitulado "Educação para conservação da Caatinga no Jardim Botânico da Fundação Zoo-botânica de Belo Horizonte", incluiu portanto, além da exposição, outras ações como a coleta de espécies nativas da Caatinga de Minas Gerais, concepção de materiais educativos e ações de educação nas comunidades dos locais de coleta.

De acordo com CAA1 e CAA2, a concepção do projeto para a inscrição no "Prêmio Projetos Educacionais Modelos nos Jardins Botânicos brasileiros" envolveu funcionários do Jardim Botânico, do Jardim Zoológico e do Serviço de Educação Ambiental da FZB-BH. Durante esta etapa e na execução do projeto, estava à frente da coordenação, CAA1 do departamento Jardim Botânico.

Além da infraestrutura da estufa, como contrapartida a FZB-BH realizou parte das reformas estruturais para instalação da exposição, destacou funcionários para a montagem de aparatos e plantio de espécies, forneceu transporte para coleta das espécies e alguns materiais para a execução de ações 
junto às comunidades dos locais de coleta. Foram realizadas atividades e coletas nas regiões de Caatinga presentes em Minas Gerais, especificamente no Vale do São Francisco, ao norte do estado, e no Vale Jequitinhonha, faixa de Caatinga que se estende pela região nordeste de Minas Gerais.

Como é possível perceber pelas entrevistas, para a FZB-BH o vínculo com a Rede Brasileira de Jardins Botânicos (RBJB) e o BGCI é bastante importante, propiciando espaço para a troca de experiências e práticas. Esse vínculo demonstra também a intenção dos agentes no cumprimento das diretrizes e estratégias para a educação ambiental incentivadas por essas associações. Vale destacar ainda que a FZBH-BH está inscrita no Sistema Nacional de Jardins Botânicos (SNJB) do MMA, sendo assim submetida a regulação externa do ministério. Vale notar que foi contudo, o financiamento via "Prêmio Projetos Educacionais...", por meio BGCI e parcerias, que estabeleceu as principais bases norteadoras para a realização do projeto.

No caso da "Estufa do Cerrado", foi o vínculo do Instituto de Botânica com a Secretaria de Meio Ambiente e a sua inserção em uma unidade de conservação (PEFI), que possibilitaram o financiamento da exposição com verbas de compensação ambiental. Nota-se que esse vínculo submete os programas e projetos do instituto e do jardim às leis e diretrizes de meio ambiente do estado e em última análise, às politicas do Ministério do Meio Ambiente. Da mesma forma que a FZB-BH, o JBSP também está inscrito no SNJB, cumprindo as exigências para a inscrição e permanência no sistema. Destacamos que ainda que exista a regulação externa e que haja uma série de requisitos para se obter a verba de compensação ambiental, os conceptores tiveram, do ponto de vista das relações institucionais, liberdade para propor os objetivos e metas específicos do projeto da exposição.

Na verdade, eu acho que nós tivemos total liberdade de pensar no que colocar na exposição. Sempre houve essa liberdade. É claro, eu não era diretora geral, na época final da concepção da exposição. A diretora, (...), ela sabia e participou. Eu sempre me reportei a ela do que a gente pretendia e tal. É claro que como um órgão da Secretaria do Meio Ambiente, a gente precisava dos recursos pra implantar a exposição. Então nós tivemos também que mostrar o projeto, mas não houve qualquer tipo de interferência. (CER1) 
Vale lembrar ainda que em relação à educação nos jardins botânicos, pode haver uma regulação por meio da Política Nacional de Educação Ambiental (PNEA), direcionando as atividades educativas para a conservação ambiental e desenvolvimento sustentável.

\subsubsection{A fase de execução dos projetos e instalação das exposições}

A execução do projeto "Educação para conservação da Caatinga no Jardim Botânico da Fundação Zoo-botânica de Belo Horizonte" durou aproximadamente um ano e, segundo CAA1, ao longo de todo o período contou com a participação direta de nove pessoas, sendo quatro delas do Jardim Botânico, outras quatro do Serviço de Educação Ambiental (SEA) e uma do Jardim Zoológico. Durante a coleta, montagem da exposição e produção dos materiais educativos participaram outros funcionários da FZB-BH, além do auxílio técnico de membros da Sociedade de Amigos da FZB-BH ${ }^{39}$ para a realização de orçamento e prestação de contas.

De acordo com todos os conceptores entrevistados, o processo de execução do projeto teve uma gestão muito compartilhada entre os participantes. Ainda que CAA1 fosse oficialmente a coordenadora do projeto, as diversas decisões para o cumprimento dos objetivos foram sempre tomadas em conjunto. Por conta das ações do projeto terem características específicas, o envolvimento das equipes foi mais intensa conforme a área de atuação. Assim, de acordo com CAA2, o levantamento de espécies e coleta nas áreas de caatinga selecionadas contou com uma maior participação da equipe do Jardim Botânico. $\mathrm{O}$ desenvolvimento do programa educativo esteve a cargo da equipe do SEA (CAA4). Já a produção da exposição contou com todas as equipes e ainda com a participação de CAA5, responsável pela expografia.

A gente sempre compartilhava tudo; assim, cada um tinha uma responsabilidade, mas as responsabilidades também

\footnotetext{
${ }^{39}$ A Sociedade de Amigos da Fundação Zoo-Botânica de Belo Horizonte (FZB-BH) é uma instituição sem fins lucrativos, que tem como objetivo contribuir para a conservação e aprimoramento do patrimônio da ZooBotânica, apoiando ações educativas, científicas e culturais. Além disso, contribui para o aumento das fontes de renda da fundação.
} 
eram compartilhadas em reuniões, assim, decisões. Bom, o pessoal da educação ambiental ficava mais a frente com as escolas, com o que levar para as escolas, as atividades que elas fariam lá; eu e CAA1, a gente ficava mais por conta de saber quais os locais a gente ia visitar para a coleta, tentando identificar algumas plantas que seriam interessantes; (...) e o Engenheiro Florestal, um colega nosso, tinha uma responsabilidade de controle da verba, mas era tudo muito compartilhado; então, eu me sinto também muito inserida, assim, nas questões, embora eu tivesse responsabilidades bem definidas, na identificação das espécies, no cultivo de algumas delas. (CAA2)

Vale destacar que a produção da exposição foi vinculada à coleta das espécies e os materiais educativos para professores e público espontâneo foram desenvolvidos no contexto da exposição (figura 3.5). Um aspecto interessante sobre montagem do mobiliário expositivo, foi a participação de funcionários da fundação que tinham ligação com a realidade das comunidades que habitam a Caatinga de Minas Gerais e portanto, dominavam saberes como por exemplo, técnicas de construção como "Adobe"40 (figura 3.5).
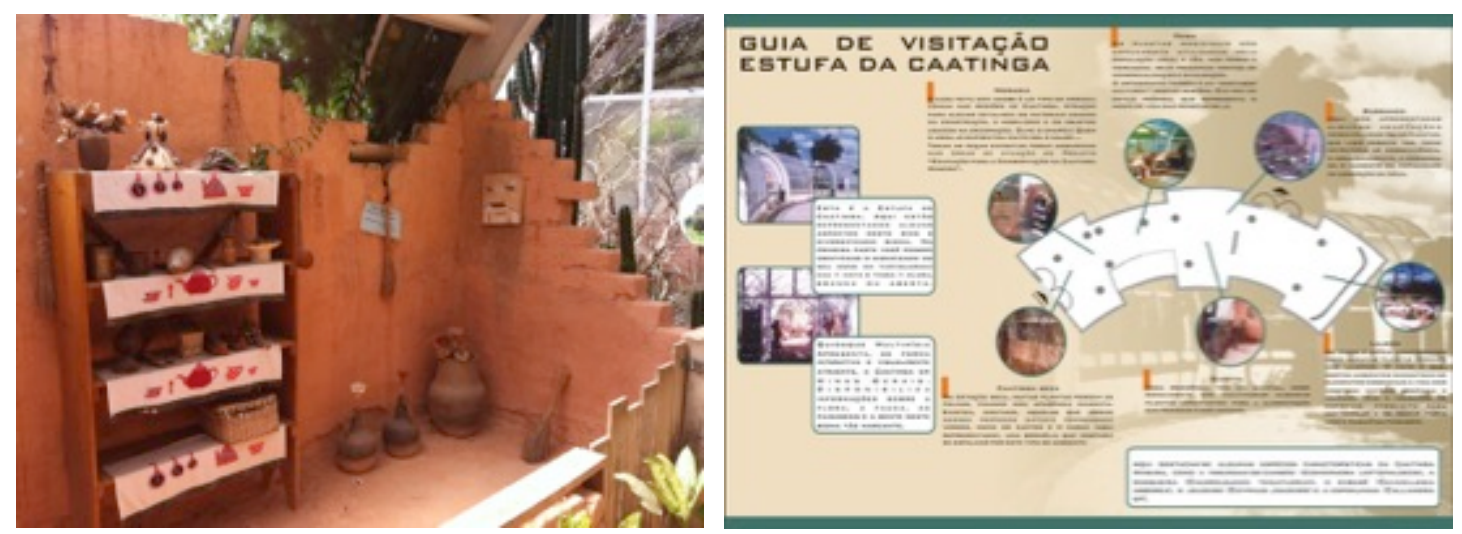

Figura 3.5: Representação da Casa de Adobe na exposição "Estufa da Caatinga Mineira” (à esquerda) e material educativo para público em geral - guia de visitação (à direita).

Em relação à instituição, CAA4 afirma que as fases de execução do projeto foram relatadas à direção, não havendo nenhuma interferência na condução ao longo do processo. Para a organização financiadora (BGCI e parceiros) foi realizada a prestação de contas com base nos critérios de orçamento

\footnotetext{
${ }^{40}$ Adobe é uma mistura de argila, areia, água e outros componentes naturais, utilizado na produção de tijolos crus.
} 
apresentados no projeto e um relatório com as realizações do projeto segundo os objetivos e metas, sendo que todas foram atendidas, a saber: amostragem de vegetação e coleta de espécies de interesse, implantação de exposição didática sobre a Caatinga em estufa, e desenvolvimento de programa educativo para público em geral e das comunidades em que ocorre o bioma em Minas Gerais (ANDRADE, 2004). No contexto do programa educativo, foi desenvolvido o programa de visitas, implantação de sistema interativo de consulta, capacitação de equipes para atuar na exposição, além da produção de diversos materiais como jogo, kit, pranchas, caderno do educador, guia de visitação, dentre outros. No que se refere à exposição, o relatório destaca o cultivo de mais de 30 espécies de plantas identificadas pela família botânica, exposição de diversos objetos, tais como peças de artesanato, utensílios domésticos, vestuário, alimentos, plantas medicinais e outros bens culturais das regiões visitadas (ANDRADE, op. cit.).

O conceito inicial da exposição que pautou o projeto foi, segundo os entrevistados, executado de maneira próxima ao original. Essa afirmação pôde ser constatada pela comparação entre o documento fornecido pelos conceptores e as observações realizadas na exposição, evidenciando que os conteúdos principais e a sua distribuição no espaço expositivo sofreram pequenas alterações. Mudanças pontuais, principalmente relacionadas à expografia, ocorreram em função das coletas tanto de espécies vegetais, como de objetos e artesanato junto às comunidades locais. Houve também a inserção de elementos não previstos inicialmente tais como a "feirinha" e vestígios de fauna (CAA5).

Um ponto destacado por CAA1 e CAA2 foi a simplificação dos conteúdos apresentados, de forma a adequá-los às especificidades do espaço de uma exposição, além de os tornar compreensíveis para o público. Nos textos, a limitação de tamanho e a adequação da linguagem foram aspectos desafiadores para a equipe da área científica. No entanto, como ressaltou CAA2, apesar de realizar pesquisa científica, a missão da instituição dá ênfase à educação para a conservação, de tal forma que não houve qualquer pressão para que o discurso científico tivesse maior estatuto nas ações voltadas para o público, como a exposição e os materiais educativos. 
A dificuldade que eu sinto, do conteúdo, em relação a como expô-lo, expor esse conteúdo, é aquilo que eu já disse, de você conseguir extrair daquele conjunto de informações que você tem, de extrair muito, falar muito bem sobre ele em poucas frases. (CAA2)

O pessoal da Educação Ambiental sempre fala muito para a gente, não pode ficar incompreensível, era até um motivo de umas discussões, assim, que a gente não podia pôr uma palavra muito difícil. (...) É preciso ser simples, não precisa ser raso; então, é... mas era difícil a gente chegar num consenso nesse sentido, assim, de você achar as palavras certas.(CAA1)

Um aspecto interessante da execução do projeto diz respeito às visitas realizadas nas áreas de Caatinga de Minas Gerais. Segundo CAA1 e CAA2, essas viagens, presentes no projeto, tinham como objetivo conhecer e coletar espécies vegetais para a conservação ex-situ, conhecer as comunidades que habitam essas regiões e seus modos de vida, além de realizar encontros com ações de educação ambiental junto às populações. De acordo com essas conceptoras, ainda que as questões culturais já estivessem incluídas entre os conteúdos da exposição, com a previsão de uma área expositiva dedicada ao assunto desde a fase de projeto, os encontros e vivências realizados junto às populações locais reforçaram a importância de compartilhar os conhecimentos, arte, hábitos, costumes e as relações dos sertanejos com a natureza (figura 3.6). CAA1 e CAA2 também avaliam que houve um impacto das ações realizadas sobre as comunidades, no sentido de valorizar o bioma e a cultura local.
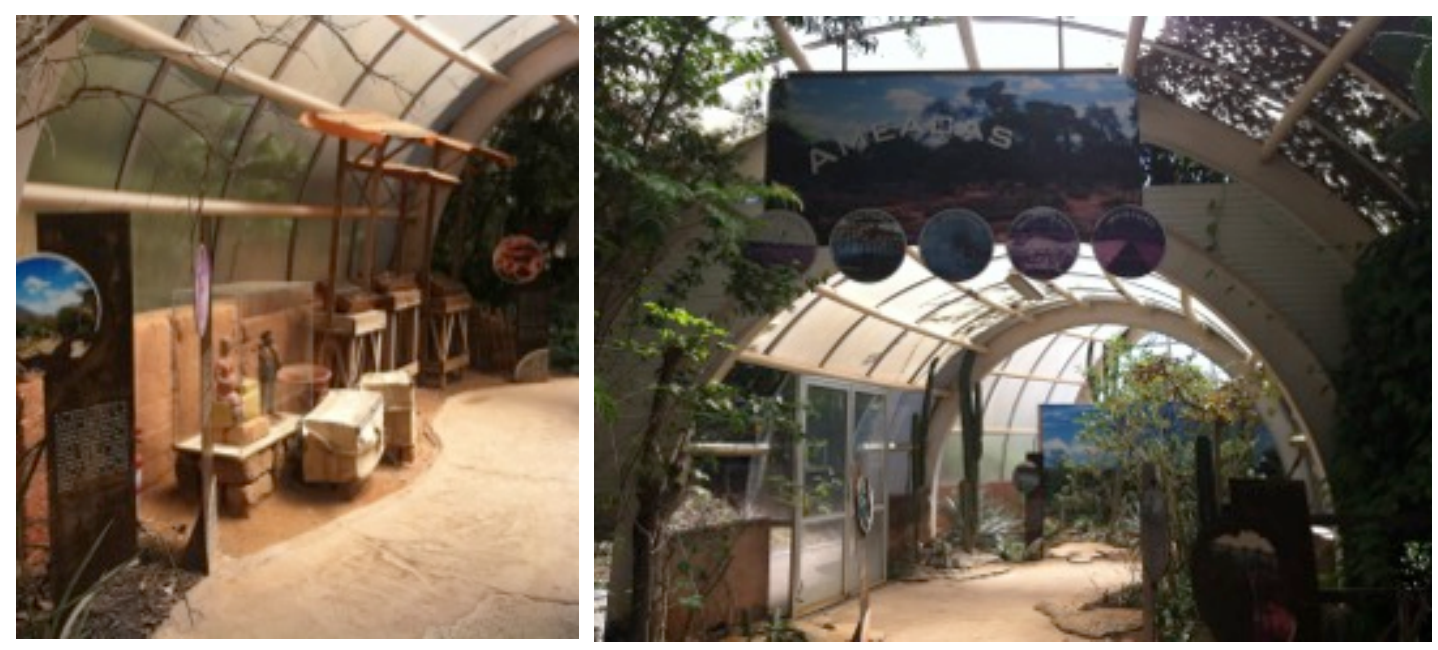

Figura 3.6: Objetos de artesanato e representação das feiras com produtos medicinais; vista da representação dos ambientes naturais da Caatinga. 
Sim, porque tudo ali é proveniente das coletas. Então, por exemplo, a parte da Feirinha, que é da vem... das plantas medicinais, foi decorrente de... das feiras que a gente visitava, daquele intercâmbio, aquela troca; a parte cultural também foi de uma visita ao Vale do Jequitinhonha, que, onde as pessoas faziam aquelas esculturas, onde elas fazem, não é; e as plantas, são as plantas que a gente trouxe.(CAA2)

A pesquisa de público realizada pelo MMA mostra que a maior parte das razões apontadas pelos entrevistados sobre a importância de conservar a Caatinga, ligam-se às questões etnocêntricas, incluindo a vulnerabilidade econômica e as questões socioculturais dos habitantes do bioma (BRASIL, 2012). Por meio da comparação dos dados dessa pesquisa com aquela realizada seis anos antes, é possível perceber que os motivos biocêntricos (e.g. conter o desmatamento, queimadas, destruição; preservar a vegetação ou florestas) para a conservação dos biomas deixaram de ser predominantes, havendo um número maior de justificativas que levam em consideração as questões de ordem social, econômica e cultural. A vulnerabilidade econômica da população que habita as regiões da Caatinga e a sua dependência dos recursos naturais, são também destacadas no texto oficial de apresentação do bioma no portal do MMA, como justificavas para a ampliação do conhecimento e conservação da Caatinga.

Os conceptores da "Estufa da Caatinga" consideram que, de forma geral, os conteúdos científicos apresentados na exposição são atuais, mesmo transcorridos dez anos da inauguração da exposição. Segundo CAA1, CAA2 e CAA5, foram consultados livros e cartilhas sobre a Caatinga publicados pelos órgãos oficiais, como o MMA, além de alguns artigos científicos. Quanto à educação ambiental, além da experiência advinda das práticas realizadas pelo Setor de Educação Ambiental (SEA), foram utilizadas estratégias e estudos de caso publicados pelo BGCI. No que se refere à expografia, não foram consultados materiais de referência.

A análise dos documentos e as entrevistas realizadas junto aos conceptores da "Estufa do Cerrado" mostram que desde a ideia inicial à implantação da exposição, estiveram envolvidos dois agentes, CER1 e CER2, pesquisadores da área acadêmica em biologia. Com a participação da 
organização social especializada em expografia, diversos outros agentes passaram a trabalhar na execução do projeto. Além de CER3, especialista em biologia já citada anteriormente, participaram, por meio da contratação pela organização social, uma equipe de coordenação, equipe de cenografia e expografia, editores de texto e imagens, equipe de mobiliário e produção, iluminadores, além de empresas subcontratadas pontualmente para a produção dos aparatos interativos.

A escolha e seleção de conteúdos e das formas como eles foram apresentados passou, em todas as fases, pela aprovação de CER1 e CER2. Essa hierarquia sobre as seleções, recortes e decisões está pouco explícita nos documentos analisados, mas de acordo com CER3, responsável pelo desenvolvimento de conteúdo científico e CER4, responsável pela cenografia, sempre foi claro que os dois pesquisadores deveriam ser consultados e na maior parte das decisões era deles a "palavra final". Tanto CER3 como CER4, ressaltam no entanto, que havia um ambiente muito favorável ao diálogo. Conforme aponta CER3, a concepção de alguns conteúdos como a conservação da biodiversidade e aqueles presentes no painel final da exposição, não envolveu a participação desses dois agentes, cabendo a ela e a equipe de redação e expografia a decisão final.

Então, assim, eu me sinto bastante envolvida, acho que eu contribui, mas sempre teve esse veto e essa supervisão bem forte de CER2 e CER1. (...) Então, quer dizer, no final eles tinham um poder de interferência, pelo menos do meu ponto de vista do que eu entendia, um poder total. (CER3)

Eu acho que sempre houve essa conversa, eu tive a sensação durante todo o processo é que todos os contratados, eu, o estúdio, as meninas do Layout, eles (CER1 e CER2) sempre respeitaram muito o que a gente falava. (CAA4)

O conceito inicial da exposição que pautou o projeto foi, segundo os entrevistados, executado de maneira muito próxima ao original. No que se refere à estrutura, conteúdos principais e a sua distribuição no espaço expositivo, a análise dos documentos (proposta expositiva e projeto executivo), além da observação, corroboram tal afirmação. De acordo com CER2, a estrutura da estufa impediu que alguns conteúdos fossem colocados, tais como a fisionomia 
do Campo úmido. Foi também o espaço dedicado à representação das fisionomias (ambiente natural) que levou a cortes que excluíram a apresentação de objetos relacionados à cultura das populações que habitam o Cerrado, reduzindo os aspectos socioculturais aos textos e imagens presentes no painel final da exposição (figura 3.7).
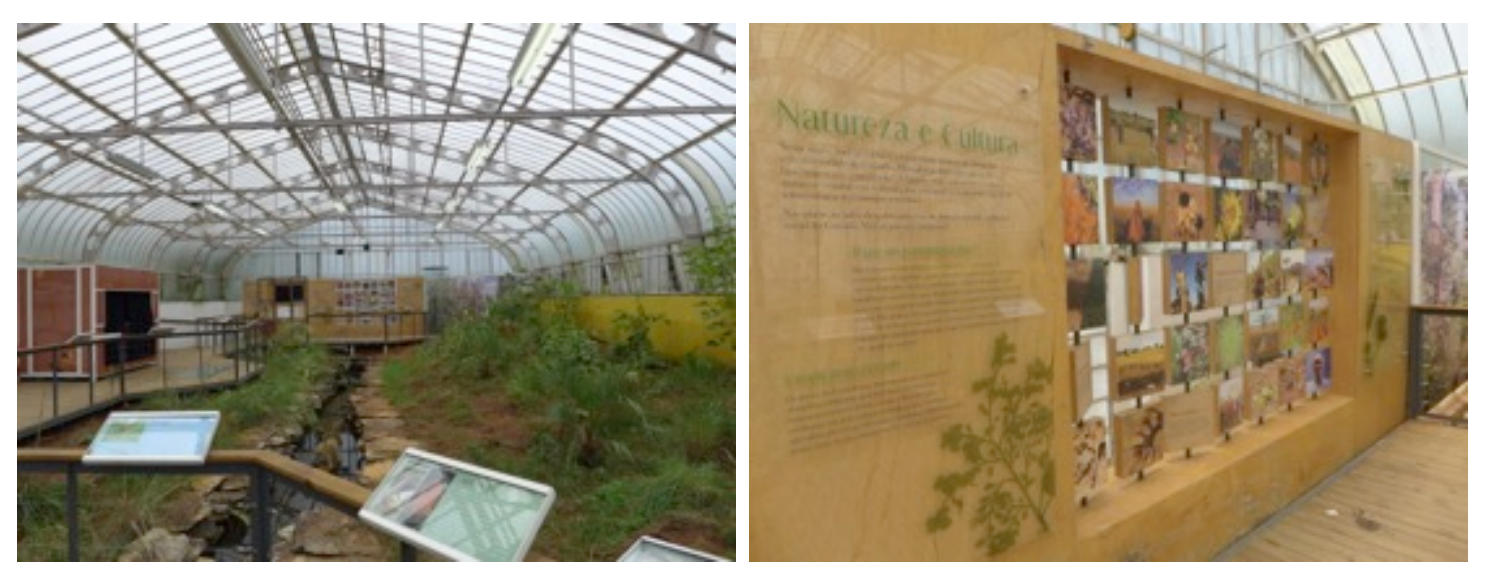

Figura 3.7: Vista geral da representação do ambiente natural de Cerrado e painel final da exposição, que inclui elementos culturais.

Segundo CER1 e CER2 durante a fase de execução da exposição houve pouquíssima interferência dos agentes do IBt. 0 diretor do Jardim Botânico à época esteve ciente nas várias etapas do processo, mas não influenciou nas decisões. Alguns funcionários do instituto participaram da coleta de plantas e implantação da exposição e uma estagiária acompanhou boa parte do processo.

A empresa de desenvolvimento de exposições que elaborou o projeto ficou a cargo da expografia. De acordo com CER4 o conceito já trazia uma ideia que foi traduzida no projeto a partir de trocas entre as equipes de conteúdo e expografia. Durante a execução, soluções expográficas foram sendo adicionadas e outras modificadas. CER3 ressalta que em boa medida os conteúdos determinaram a expografia, mas que por outro lado alguns conteúdos como a quantidade de textos por exemplo, foi condicionada às possibilidades expográficas.

No geral, o papel da empresa era mais voltado a apresentar soluções de expografia para os conteúdos determinados com algumas orientações na forma de apresentá-los. De qualquer forma, segundo CER3, as soluções eram no geral 
bem recebidas pelos pesquisadores (CER1 e CER2), uma vez que traziam possibilidades mais atuais e interativas na relação do público com a exposição (figura 3.8). As propostas expográficas levantaram também a possibilidade de expor outros objetos e com isso a necessidade da criação de novos textos e seleção de novas imagens.
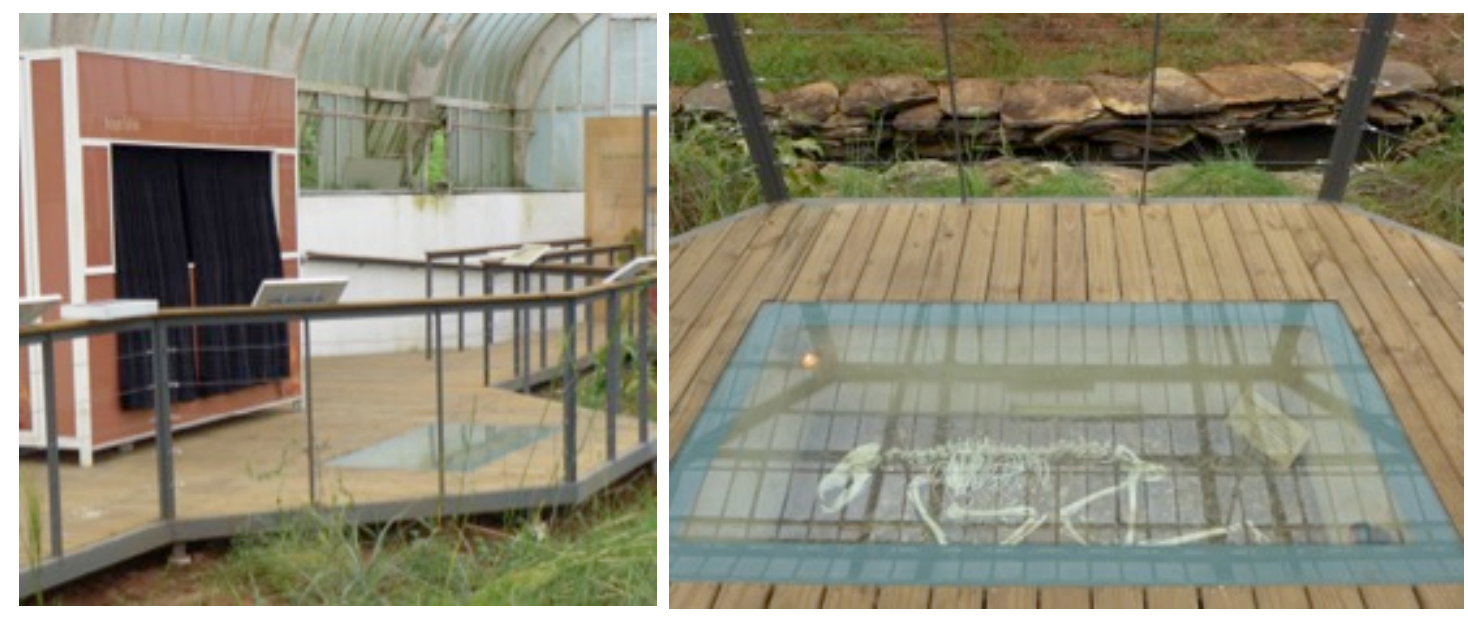

Figura 3.8: Vista do aparato expositivo com vídeo e à frente no chão, janela de piso, na "Estufa do Cerrado". Detalhe da janela de piso.

Dentro da própria equipe de conteúdo que incluía os pesquisadores e CER3, houve também muito espaço de diálogo. Havia segundo CER1, uma confiança muito grande em CER3, que ficou responsável pela criação dos textos, seleção de imagens e objetos, mediação entre o conteúdo científico e expografia. Essa consultora foi o elo fundamental entre a equipe de expografia e os pesquisadores.

0 pessoal de desenho gráfico, que trabalhou muito associado à CER3, a CER3 trabalhou muito junto com a (organização social) também, até a gente. Mas a parte científica mesmo foi o CER2, CER1 e CER3, que era contratada pelo (organização social). Então tudo que CER3 escrevia, ela mandava pra gente, a gente dava o aval, sugestões.(CER1)

Eu era o ponto focal da equipe de curadoria porque eu que tava na execução. Então eles me acionavam, por exemplo, esse povo todo, o estúdio, o design, eles falavam comigo, eu era a curadora pra eles, entendeu? Então às vezes eu falava pra eles 'calma porque isso eu vou checar com o CER1 e CER2 (...). (CER3) 
O conteúdo e expografia foram direcionados ao público espontâneo frequentador do jardim, composto em geral por famílias. Assim, os textos, infográficos e aparatos foram elaborados com linguagem compreensível pelo maior número de pessoas. Segundo a equipe de conteúdo, houve uma redução significativa na quantidade de informações e os textos foram simplificados, atendendo às especificidades de uma exposição. No entanto CER4, da equipe de expografia, avalia que há muita informação na exposição, com grande quantidade de textos, limitados pelo número de painéis que poderiam ser colocados na estrutura da estufa sem comprometer a representação do ambiente natural.

Para os conceptores da área de pesquisa, a ideia da exposição era apresentar o Cerrado como algo dinâmico onde atuam diferentes fatores que o definem e transformam. Foi com base nisso que os conteúdos da exposição foram selecionados. Para CER3, a intenção desses conceptores era que o visitante pudesse se sentir no Cerrado e conhecer tais fatores com uma mediação realizada pelos painéis e aparatos. De acordo com CER1, é essencial que o público aprenda algo após a visita. No que se refere as referências pedagógicas, CER3 relata que foram utilizadas como base as experiências de docência no ensino superior e aulas de campo de um dos pesquisadores. A experiência didática desse pesquisador, de acordo com CER1, teve papel essencial nos recortes e seleções dos conteúdos para o público.

Eu acho que isso também é importante. E quem visita o Jardim Botânico precisaria, na minha opinião, sair de lá percebendo que atrás daquela exposição existe uma equipe de pesquisa. (...) Não só como educação, mas também como uma parte de conhecimento. Eu acho que o visitante do Jardim Botânico tem que sair de lá aprendendo alguma coisa. (CER1)

Então essa estrutura geral, acho que vem da cabeça de CER2, da linha, das aulas que ele sempre deu, da linha de pesquisa dele, da forma como ele via. (...) Então essa estrutura geral do conteúdo veio desse conteúdo que CER2 sempre apresentou o Cerrado em aula. Se você olhasse, você poderia fazer de outras maneiras, mas aquela era a maneira natural pra ele e a gente seguiu o que ele falou. (CER3) 
Ainda acerca das ações voltadas à educação, vale destacar que não houve, no âmbito do projeto, o desenvolvimento de um programa educativo que incluísse a concepção de roteiros de visitação, materiais educativos e formação de equipes. De acordo com CER1, essas ações foram sugeridas no projeto e deveriam ser contrapartidas da própria instituição, uma vez que há equipes que atuam na área de educação do jardim. De fato, segundo a pesquisadora, elas não estavam previstas para serem executadas com os recursos destinados à produção da exposição.

Eu acho que essa deveria ter sido uma contrapartida do Instituto, que tem equipe de educação, e acabou não sendo cumprida. Porque na verdade a verba que nós tínhamos, pra esse projeto, foi usada toda na reforma da estufa, a parte interna, e foi usada pra fazer a exposição. (CER1)

Conforme relataram CER1, CER2 e CER3, a participação do Núcleo de Pesquisa em Educação para a Conservação foi muito pequena ao longo do processo de produção da exposição. Com isso, a exposição pode ter sido menos legitimada junto aos agentes que atuam no setor. Ainda segundo CER1, esse aspecto, somado a falta de recursos e o esquema de contratação de educadores pelo jardim, podem explicar a ausência de um programa educativo para a exposição.

Eu dei uma palestra sobre o Cerrado, uma visão geral, clima, solo, vegetação, fauna, dá uma ideia, mas foi só. 0 ideal fosse que a cada turma nova de monitores tivesse uma palestra. Eu me dispus a fazer, mas se as pessoas não chamam... (CER2)

Eu acho que se ela estivesse lá, ela mexeria os pauzinhos pra coisa andar. Porque a ideia era legal, mas ela não pode, dentro do Botânico, ser visto como a ideia de CER1. (...) Aos poucos eu fui percebendo que a exposição não tava muito adotada, que ninguém adotou ela. (CER3)

Eu se fosse coordenar isso, teria tentando amarrar desde o começo pra que uma pessoa (da educação), talvez ela não quisesse ter participado de todas as reuniões, mas o fato dela ter participado da ideia ela ia criar uma relação com a exposição". (...) Eu não sei, talvez a coordenação do núcleo (de pesquisa em educação para conservação) até tenha 
gostado, quisesse se envolver e tudo, eu acho uma pena. (CER3)

No que se refere à consulta de referências de conteúdos específicos, CER3 relata a consulta à bibliografia científica sobre o Cerrado. Em grande parte, foram consultados capítulos de livro ou artigos de pesquisas em biologia, além de alguns materiais da Empresa Brasileira de Pesquisa Agropecuária (EMBRAPA).

Outro aspecto importante acerca do conteúdo científico apresentado é a atualidade e consensualidade. Para os conceptores de conteúdo (CER1, CER2 e CER3), as informações sobre o Cerrado apresentadas na exposição além de atuais, são consensuais entre os pesquisadores da área, pelo menos no nível de profundidade em que foram apresentadas (CER3).

Ainda que a importância da biodiversidade seja um tema consensual na sociedade, segundo Santos e colaboradores (2005) trata-se de uma área controversa em suas aplicações e de um conceito em permanente reinterpretação. De acordo com os documentos e as entrevistas com os conceptores de ambas exposições, não houve intenção de apresentar aspectos controversos sobre os temas tratados, no entanto conforme apontou CER3, há opiniões diversas por exemplo, sobre a conservação da biodiversidade e o crescimento econômico do país, evidenciadas nos posicionamentos dos grupos chamados "ruralistas" e "ambientalistas". No caso da Caatinga, há também uma polêmica, que ainda persiste na sociedade brasileira, acerca da desvalorização do bioma em função das suas características, como a secura e aridez, que "impedem" o desenvolvimento (CAA2). Vale destacar também que a Caatinga é, entre os biomas brasileiros, um dos menos conhecidos do ponto de vista de sua biodiversidade e possibilidades do uso sustentável de seus recursos, além de ter a menor área protegida por meio de Unidades de Conservação (MMA, 2017c).

Outra aproximação entre as concepções dos idealizadores das exposições que foi levantada por meio das entrevistas, é a atualidade da expografia. Os conceptores afirmam que as exposições são bastante inovadoras pela implementação de proposta imersiva de apresentação dos biomas. Para os conceptores da "Estufa do Cerrado" é importante que haja atualização periódica dos recursos audiovisuais e eletrônicos da exposição. No caso da Caatinga, segundo CAA2 e CAA3, esses recursos não estão presentes propositadamente na 
exposição, mas os terminais de consulta para o aprofundamento dos conteúdos, estavam à época desta pesquisa, em reformulação.

Os resultados da análise dos documentos e das entrevistas realizadas junto aos conceptores da exposição "Estufa do Cerrado" mostram a importância do discurso científico, na medida em que os conceptores que atuam no campo do controle simbólico são aqueles que detêm maior poder e controle sobre o processo de recontextualização. CER3 é outra profissional da área de biologia que também configura como agente na produção do discurso expositivo. Envolveram-se ainda empresas terceirizadas que realizaram diferentes serviços. Neste caso, nota-se que também estão presentes os discursos dos profissionais responsáveis pela expografia, tecnologia e dos técnicos de montagem da exposição. Ressalta-se ainda a falta de envolvimento de educadores, não havendo a participação do setor responsável pelas ações de educação do Jardim Botânico de São Paulo, ou de outro profissional da área de educação.

Já a análise do processo de execução da "Estufa da Caatinga Mineira" mostra a participação de diferentes agentes, dos departamentos Jardim Botânico, Jardim Zoológico e do Setor de Educação Ambiental, com poder de decisão similar. 0 posicionamento desses agentes na instituição e a própria função expressa pela FZB-BH apontam para que não haja um estatuto diferenciado entre o discurso científico e os outros discursos que estão em jogo na recontextualização pedagógica. Um aspecto importante sobre esse processo é a participação de agentes das áreas de produção de conhecimento científico (Botânica e Zoologia) e o Setor de Educação Ambiental em todas as etapas do projeto. Além disso, é relevante denotar a importância dada para a elaboração de materiais educativos e inserção de outros saberes tradicionais e questões socioculturais na exposição.

\subsubsection{A autonomia entre os campos}

Conforme afirmamos anteriormente, o processo de produção e reprodução do discurso pedagógico é extremamente dinâmico, isso porque as agências e agentes que atuam nos campos recontextualizadores ocupam posições de oposição e complementariedade, estabelecendo espaço para a luta 
pelo controle, para a resistência e inércia (BERNSTEIN, 1996). Além disso, como ressalta o autor, esses campos podem possuir maior ou menor autonomia, fazendo com que os textos produzidos nos diferentes níveis do dispositivo pedagógico reproduzam em suas mensagens as relações de poder.

De acordo com Morais e Neves (2007b), a teoria de Bernstein propõe que um maior grau de recontextualização dos discursos leva a um maior espaço para mudança. As condições para que isso ocorra têm relação com o regime político de uma sociedade e com as maiores possibilidades de recontextualização dos discursos, que por seu lado estão ligadas a existência de um maior número de campos e contextos.

Para Bernstein (op. cit.), no contexto contemporâneo, o discurso pedagógico produzido depende cada vez mais da ideologia dominante no CRO e da autonomia do CRP. De acordo com Neves e colaboradoras (2000), os textos oficiais são constituídos de princípios e normas do discurso regulador geral influenciado pelos campos de estado, economia e controle simbólico. Contudo em suas mensagens esses textos acabam também por refletir as opções mais adequadas a um determinado contexto educativo por meio da influencia exercida pelo CRP e possíveis campos de recontextualização ao nível da reprodução.

Os resultados da análise do processo de produção dos discursos expositivos aqui estudados mostram que os conceptores idealizam os jardins botânicos como locais importantes para educação para conservação da biodiversidade dos biomas apresentados. Para eles, as exposições aparecem como elementos que possibilitam atingir esse ideal na medida em que proporcionam para o público em geral conhecer os biomas, e a partir desse contato perceber a importância de sua conservação.

Dentre os textos oficiais levantados nesta investigação, o papel da educação em espaços como jardins botânicos está relacionado à educação ambiental para conservação da biodiversidade e desenvolvimento sustentável. Esses textos refletem os princípios gerais da sociedade na medida em que a conservação do meio ambiente é um tema relevante na sociedade atual. Esse princípio também se reflete nas concepções dos idealizadores das exposições ou seja, nos agentes do campo de recontextualizador pedagógico, dado que os objetivos pretendidos são justamente a conservação dos biomas. 
Vale destacar que o discurso pedagógico é influenciado pelos princípios dominantes na sociedade, mas não é resultado direto desses, uma vez que podem ocorrer recontextualizações, fazendo com que o discurso produzido não seja igual aquele que é reproduzido (FERREIRA e MORAIS, 2013). Ainda que em ambas as exposições esses princípios ideológicos estejam fortemente presentes nos ideais e objetivos dos conceptores das exposições, os conteúdos selecionados para esse fim não são exatamente os mesmos, mostrando que determinados discursos têm maior ou menor estatuto. Essas seleções podem refletir a influência do CRO, a autonomia dos agentes e agências do CRP e o posicionamento dos agentes dentro desse campo.

No CRP da exposição do Cerrado, os mesmos agentes que produzem os discursos específicos ao nível do controle simbólico, são aqueles que detêm o poder de decisão e seleção dos significados legítimos e das formas legítimas de sua transmissão. Nesse caso, o poder e controle da produção do discurso estão na mão de um número menor de agentes. Martins (2011) evidenciou também que os mesmos agentes podem atuar na produção das ações educativas dos museus ao nível do CRP, na determinação das politicas públicas via atuação junto às Redes de Educadores de Museus (REMs) para a constituição de um programa nacional de educação em museus ao nível do CRO e ainda, esses mesmos atores produzem conhecimentos no campo do controle simbólico por meio das pesquisas que realizam na formação acadêmica.

Segundo Marandino (2015), o contexto histórico e político e a forma como se dá a divisão do trabalho nas diferentes instituições museais determinam um maior ou menor controle sobre o discurso expositivo. No caso da exposição "Estufa do Cerrado" evidenciamos que a participação de atores do Núcleo de Pesquisa em Educação para Conservação do jardim foi bastante limitada, mostrando que há um potencial espaço de contestação no que se refere às relações entre o instituto e o jardim, haja visto a função educativa da exposição e o papel desse setor na instituição. Para Rocha e Cavalheiro (2001), a vinculação do Jardim Botânico ao Instituto de Botânica não significou uma ampliação das relações entre o espaço e a instituição de pesquisa, ao contrário, como afirmam os autores "a ligação entre o Instituto de Botânica e o atual Jardim Botânico de 
São Paulo tornou-se mínima com o passar das décadas, limitando-se apenas ao caráter administrativo" (ROCHA e CAVALHEIRO, op. cit. p. 584).

A pesquisa realizada por Martins (op. cit.) aponta também para a influência dos financiamentos das exposições no processo de recontextualização pedagógica. No caso dos processos estudados pela autora, as políticas de financiamento, centradas muitas vezes no CRO, evidenciaram um menor grau de autonomia entre esse campo e o CRP. Vale lembrar que o financiamento da exposição sobre o Cerrado foi possível pela vinculação dos agentes do controle simbólico e do instituto à Secretaria de Meio Ambiente de Estado, agência que atua no CRO, indicando assim uma possível regulação do processo por esse campo. Mas nota-se, ao longo da execução, que essa regulação foi bastante limitada, conferindo aos conceptores de conteúdo específico ainda mais autonomia para a determinação do que e do como do discurso expositivo.

Com base no panorama em que há atuação de um menor número de agentes no processo de recontextualização do discurso expositivo, pois além dos conceptores de conteúdos científicos, houve apenas o envolvimento de indivíduos contratados para a expografia e ainda, que esses se reportavam justamente aos pesquisadores que concentram o poder e controle sobre as decisões, podemos dizer que há uma tendência para um menor potencial de mudança. Isso significa que o discurso expositivo final deve estar mais próximo do discurso científico, havendo um menor grau de recontextualização e menor papel regulador das agências e agentes do CRO, estado e mesmo do controle simbólico. Como foi dito no início desta pesquisa, as características relacionadas ao "que" e "como" dos discursos expositivos serão analisadas no capítulo a seguir. Com isso, será possível delimitar mais precisamente o estatuto do discurso científico na constituição das mensagens presentes na exposição sobre o Cerrado.

Na exposição "Estufa da Caatinga", as decisões foram mais compartilhadas entre os diversos agentes que participaram do CRP. Vale lembrar que a produção do discurso expositivo por esses agentes foi regulada pelos objetivos do programa que permitiu o acesso aos recursos financeiros, e em última análise, das diretrizes para a educação do BGCI e organizações parceiras. Da mesma forma que na exposição sobre o Cerrado, a regulação direta da FZB-BH e da 
agência de estado a qual se vincula a fundação foi muito limitada, conferindo autonomia aos agentes do CRP. No entanto, vale lembrar que as organizações que financiaram a exposição têm papel importante para auxiliar na implementação da políticas públicas de educação ambiental, mostrando que há uma influência, mesmo que menos explícita, dos discursos oficiais sobre a recontextualização pedagógica que resultou no discurso expositivo.

Os principais aspectos sobre a composição dos campos recontextualizadores dos museus e seus textos, bem como os principais agentes e agências que participaram dos processos de recontextualização dos discursos expositivos da "Estufa da Caatinga Mineira" e da "Estufa do Cerrado", são apresentados no esquema a seguir (figura 3.9). 


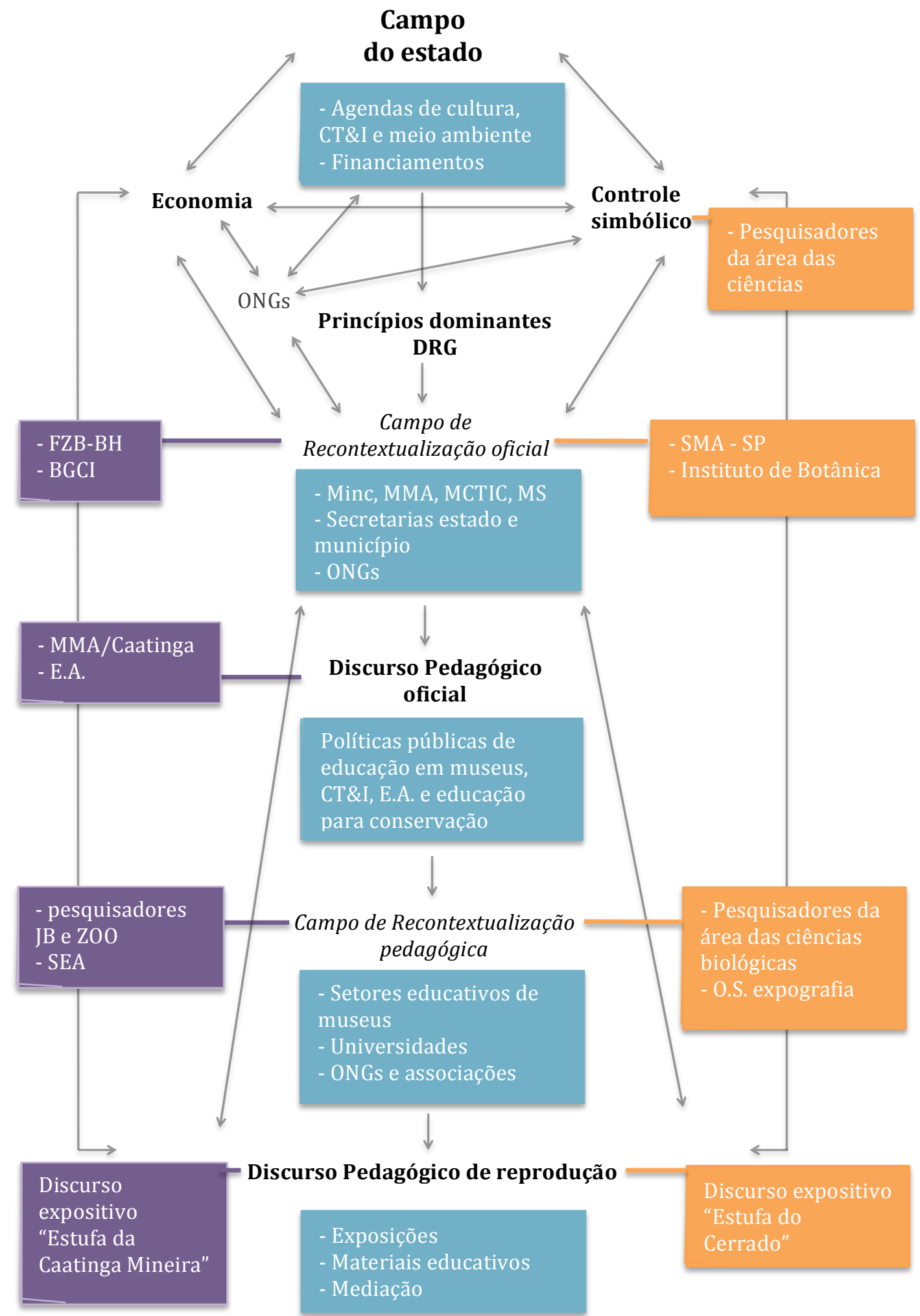

Figura 3.9: Modelo do Discurso Pedagógico adaptado de Bernstein (1996), apresentando na coluna central os principais aspectos da composição dos campos recontextualizadores e discursos relacionados aos museus. Os principais agentes e agências envolvidos na produção dos discursos expositivos da "Estufa da Caatinga" e "Estufa do Cerrado" são apresentados à esquerda e à direita, respectivamente. FZB-BH: Fundação Zoo-botânica de Belo Horizonte; MinC: Ministério da Cultura; MMA: Ministério do Meio Ambiente; MCTIC: Ministério da Ciência, Tecnologia, Inovação e Comunicações; SMA: Secretaria de Meio Ambiente do Estado de São Paulo; ONGs: Organizações Não-Governamentais; E. A. Educação Ambiental; CT\&I: Ciência, Tecnologia e Inovação; JB: jardins botânicos; ZOO: zoológicos; O.S.: Organização social. 
A análise realizada mostra que nos museus os processos de recontextualização são bem diferentes daqueles que ocorrem no âmbito da educação formal. Dentre essas diferenças, destacamos a diversidade de agências que participam do CRO e a inexistência de um marco legal que estabeleça diretrizes para a pedagogia museal.

Destacamos também, por meio da análise realizada, que a abrangência do CRO dos museus está ligada às diversas tipologias desse tipo de instituição e suas vinculações com o campo do estado. Essa diversidade de agências e agentes que atuam no CRO dos museus está relacionada ao contexto histórico, político e social dessas instituições, fazendo com que os museus de ciências, por exemplo, estejam mais relacionados às agências como o MCTIC. No caso das exposições analisadas, vale lembrar que muito antes dos jardins botânicos configurarem nas definições de museus, eles já existiam como instituições de salvaguarda de coleções, de pesquisa e para a educação em botânica.

Entre outras atribuições, o importante papel dos jardins botânicos na conservação de espécies ex-situ acabou também influenciando a sua vinculação aos órgãos ambientais do campo de estado, e por conta disso, suas atividades educativas foram ampliadas para além da educação em botânica, em um campo que ganhou força a partir da deflagração dos problemas ambientais na década de 1970, a Educação Ambiental. Isso fica claro ao analisarmos os textos oficiais e os documentos e entrevistas realizados com os conceptores das exposições, da onde se denota que o papel da educação em jardins botânicos está ligado à educação ambiental, educação para desenvolvimento sustentável ou para a conservação da biodiversidade, no entanto não se destaca no papel educativo dessas instituições uma ligação explicita com a educação em museus.

Vale destacar ainda, as linhas de financiamento para as ações de educação em museus. A nossa análise mostrou que essas linhas estão pulverizadas em diferentes agências de estado, e que a tipologia e vínculo que os museus mantêm com as agências de estado, economia ou controle simbólico poderão determinar ou facilitar o acesso a chamadas, editais e programas de financiamento. A atuação do Ibram e do Ministério da Cultura, no entanto, parece ser mais abrangente, mantendo linhas de fomento para instituições museais de todas tipologias, tamanhos e modelos. 
Essa polarização no que diz respeito às linhas de financiamento e amplitude do CRO está também relacionada à demarcação de posição dos agentes e das agências de estado. Isso pode ser evidenciado ao analisar o recente processo de fusão do MCTI com o Ministério das Comunicações, como citamos anteriormente, no qual foi extinta a Secis, secretaria responsável por implementar as politicas de popularização de ciência tecnologia e inclusão. A reação dos funcionários e da comunidade científica mostra o quão importante é manter a legitimidade dessa agência e portanto de suas ações. Uma análise análoga pode ser feita sobre as demais agências e setores que atuam no desenvolvimento e na implementação das políticas públicas e linhas de financiamento para a educação em museus, divulgação científica, educação ambiental, educação para a conservação e para o desenvolvimento sustentável.

Se por um lado os resultados mostram que há ainda uma baixa regulação da educação em museus, é possível perceber também que esse quadro vem mudando frente à ampliação dos campos recontextualizadores dos museus e por conta da discussão atual de uma política pública específica para a área, o Programa Nacional de Educação Museal (PNEM). 


\section{Capítulo 4 - Análise do "que" e do "como" do discurso expositivo sobre biodiversidade em exposições de imersão}

De acordo com o modelo do discurso pedagógico de Bernstein, o discurso pedagógico é influenciado pelos discursos oriundos dos campos presentes na dimensão da produção do discurso e também pelas características do contexto de transmissão e pelo campo de socialização primária. Como parte dessas complexas relações propostas no modelo, o discurso pedagógico não corresponde exatamente aos discursos produzidos. Isso porque ao longo dos diferentes níveis na dimensão da produção dos discursos, podem ocorrer recontextualizações, que fazem do discurso pedagógico um novo discurso.

O discurso expositivo, compreendido como um discurso pedagógico, contem na sua mensagem os conteúdos, relações, princípios e normas advindos dos discursos produzidos nos níveis de geração e recontextualização (dimensão da produção do discurso). Contudo, o discurso pedagógico também reflete na sua mensagem, o conjunto de opções adequadas a um determinado contexto e influenciadas pelas campos de recontextualização ao nível da transmissão (NEVES et al., 2000).

As mensagens são as realizações dos discursos, compreendendo seleções de conteúdos e competências a serem adquiridos (o "que" do discurso) e as relações que se estabelecem entre os conhecimentos e discursos ("o como" do discurso). Neste capítulo, o discurso expositivo sobre biodiversidade presente em duas exposições de imersão foi analisado quanto aos conteúdos e competências, e quanto às relações entre discursos e conhecimentos.

0 discurso "conhecer a biodiversidade para conservá-la" é frequente nas ações, materiais e publicações relacionados às temáticas ambientais. De acordo com as entrevistas realizadas, o objetivo norteador da concepção das exposições "Estufa da Caatinga Mineira" e "Estufa do Cerrado", analisadas nesse trabalho, vai de encontro a esse discurso: fazer com que o público conheça esses biomas e, assim, compreenda a importância de conservar a sua biodiversidade.

Foram as ideias de tornar a ciência e tecnologia mais acessíveis ao público e ampliar a visitação que deram origem às exposições centradas na experiência da visita, em particular aquelas que apresentam a técnica de imersão, na qual o 
visitante é convidado a mergulhar na temática e experimentar a mensagem (BELAËN, 2003). Essa concepção expositiva teve repercussão no desenvolvimento de exposições que recriam ambientes naturais (florestas, savanas, desertos) da forma mais autêntica possível e possibilitam simultaneamente o uso de painéis, aparatos interativos e outros elementos expositivos. Abre-se com isso, uma nova perspectiva de relação entre o público e as mensagens sobre temáticas ambientais. Muitas exposições de imersão com a recriação de ambientes naturais surgem no final do século XX e início do XXI. São alguns exemplos desse processo: "Biodôme" em Montreal (1992), "El Bosque Inundado" (2004) na Cosmocaixa de Barcelona, "Forest Secrets" no Melbourne Museum (2000) e "Rainforest e Mediterranean Biomes" no Eden Project de Cornwall na Inglaterra (2001).

A biodiversidade e conservação são assuntos bastante discutidos atualmente. As temáticas ambientais despertam interesse não só entre os profissionais e estudantes universitários, como também é um assunto corriqueiro no dia a dia das pessoas, com relevante destaque pela imprensa.

O termo diversidade biológica, percursor de biodiversidade, começou a ser usado no contexto da ampliação das discussões sobre conservação da natureza. A popularização desse termo tem início nas décadas de 1970 e 1980, e está relacionada aos trabalhos de Raymond Dasmann ${ }^{41}$ e Thomas Eugene Lovejoy ${ }^{42}$, nos quais chamam atenção para a intensidade das ações humanas sobre a vida na terra (DASMANN, 1968; SOULÉ e WILCOX, 1980). 0 termo biodiversity (contração de biological diversity) aparece com W.G. Rosen em 1985, durante o National Forum on Biological Diversity e é amplamente difundido em 1988 com a publicação da coletânea Biodiversity, organizada por Edward 0. Wilson ${ }^{43}$.

Com a Convenção de Biodiversidade em 1992 (Rio 92), passou-se a ter um conceito mais amplo de biodiversidade, que incorpora a variabilidade de

\footnotetext{
${ }^{41}$ Em 1968 Raymond Dasmann publicou o livro "Different Kind of Country" e tornou celebre a frase: "We are already fighting World War III and I am sorry to say we are winning it. It is the war against the earth."

42 Em 1980 Thomas Eugene Lovejoy escreveu o prefácio do livro "Conservation Biology: An EvolutionaryEcological Perspective, coletânea organizada por Michael E. Soulé e Bruce A. Wilcox, retomando o uso do termo diversidade biológica utilizado por Dasmann.

${ }^{43}$ A coletânea Biodiversity (1988) é composta de artigos de autoria de 60 das maiores autoridades internacionais que estavam presentes no fórum, entre elas Edward Wilsom, Paul R. Ehrlich, Norman Myers, David Ehrenfeld, Robert E. Jenkins, Thomas E. Lovejoy, Michael Soulé e James Lovelock.
} 
organismos vivos de todas as origens, compreendendo dentre outros, os ecossistemas terrestres, marinhos e outros ecossistemas aquáticos e os complexos ecológicos de que fazem parte. Abrange ainda a diversidade dentro de espécies, entre espécies e de ecossistemas.

Apesar da ampla adoção deste termo, não há um consenso para seu significado. Assim, existem dúvidas acerca de seu sentido exato e dos limites do conceito (GASTON, 1996). De acordo com Harrison e colaboradores (2004), no uso popular, a palavra biodiversidade é geralmente relacionada para descrever todas as espécies que vivem em uma dada área, assim em larga escala, a biodiversidade pode ser resumida à vida na terra.

Uma definição mais ampla de biodiversidade, segundo Harrison e colaboradores (op. cit.), deve incluir não apenas os organismos vivos e suas relações, mas também as interações com aspectos abióticos do seu ambiente. Assim, a biodiversidade, em um sentido amplo, pode incluir aspectos da composição, estrutura e função nos níveis genético, populacional, ecossistema e paisagem, considerando escalas temporais e espaciais e as relações com fatores abióticos e por fim, pode incluir o ser humano como parte da natureza.

0 conceito de biodiversidade não é exclusivo do meio científico, ainda que tenha surgido na área acadêmica, particularmente no âmbito das ciências biológicas. Contudo, parecem ser as transformações na relação dos seres humanos com o ambiente que levaram à importância que o conceito tem hoje na sociedade.

De acordo com Kawasaki e Oliveira (2003), no contexto do significado da biodiversidade em relação ao meio ambiente, criam-se novas definições ou concepções que aliam as categorias científicas, com aspectos sociais, econômicos, culturais e estéticos relacionados à biodiversidade. Atualmente, em uma perspectiva mais voltada à conservação da biodiversidade, o termo abriga aspectos relacionados à valoração intrínseca, ecológica, social, econômica, educacional, cultural, recreativa e estética da biodiversidade (PASCUAL et al., 2017). Para Marandino e colaboradoras (2009), o tratamento da biodiversidade em contextos educacionais deve incluir, além dos aspectos conceituais, dimensões culturais, econômicas, sociais e ambientais.

Nos parâmetros curriculares (PCNs), o meio ambiente é destacado como 
um dos temas transversais; nele a diversidade biológica aparece relacionada à conservação e é tratada como um conjunto de aspectos, entre os quais é enfatizada a diversidade de culturas e sociedades (BRASIL, 2000b).

Diversas pesquisas na área de educação em ciências vêm analisando as ideias de biodiversidade em materiais didáticos e divulgação científica, exposições, formação de educadores e aprendizagem (KELSEY, 1998; MARANDINO et al., 2009; MENZEL E BÖGEHOLZ, 2009, 2010; LUDE, 2010; ULBRICH et al., 2010; MOTOKANE, KAWASAKI e OLIVEIRA, 2010; OLIVEIRA, 2010).

A investigação conduzida por Lude (2010) mostrou que a definição do termo biodiversidade dada por estudantes restringia-se apenas à dimensão ecológica. De acordo com o autor, os temas da biodiversidade são altamente complexos e ao serem reduzidos acabam por simplificar demais as questões e introduzir imprecisões. A complexidade é um atributo de temas abrangentes como biodiversidade e conservação, e não deve ser reduzida, mas sim adequadamente explorada e ilustrada. Para o autor, a nomeação de organismos pode ser visto como um ponto de partida, mas deve ser seguido pelo conhecimento das inter-relações e conexões complexas.

Temas de natureza interdisciplinar, como a biodiversidade, propiciam inter-relações com outros conceitos, e podem colaborar para a compreensão de fenômenos e processos naturais, abordando os contextos em que ocorrem. Motokane e colaboradores (2010) destacam que a biodiversidade é um assunto pertinente para trabalhar conteúdos conceituais, procedimentais e atitudinais, contribuindo para a compreensão de fenômenos complexos presentes na vida dos cidadãos.

Desde que surgiram, os seres humanos convivem com a biodiversidade e o mundo natural, modificando, assim como as outras espécies, o ambiente em que vivem. De acordo com Gómez-Pompa e Kraus (2000), as relações humanas com o ambiente natural moldaram as diferentes culturas e sociedades.

Descola (1997), analisando cosmologias indígenas, afirma que nelas o ambiente aparece como sujeito de uma relação social, um prolongamento doméstico. É característica comum entre as cosmogonias o fato de não haver distinções ontológicas absolutas entre o homem e fauna-flora, todas estão unidas 
em um continuum governado por um regime de sociabilidade igual. Assim, segundo o autor, essas ideias estão muito distantes do pensamento moderno em que a natureza está em oposição às obras humanas.

Nas sociedades ocidentais, a partir do período medieval até o século XVIII, as relações entre humanos e natureza eram baseadas na crença da superioridade do homem sobre os animais (THOMAS, 1993). Tais perspectivas persistiam ainda no século XVIII, século do advento das grandes invenções, especialmente as máquinas, reforçando ainda mais o caráter utilitário dos animais. Ainda de acordo com Thomas (op. cit.), no início do séc. XIX a ideia do predomínio dos humanos sobre a natureza virou alvo de controvérsias. A produção de conhecimentos na área da história natural e o avanço das ideias de ancestralidade contribuíram para que algumas percepções antropocêntricas fossem desacreditadas.

0 crescimento das cidades teve grande influência sobre as mudanças das relações entre humanos e natureza. A partir da primeira revolução industrial, especialmente nos países em que esse processo foi mais intenso, o aumento da poluição causada pela queima do carvão, o número maior de pestes na cidade em relação ao campo, e mesmo a figura do homem do campo "idealizada", foram argumentos de uma valorização do espaço rural (THOMAS, op. cit.). Nesse processo, o valor intrínseco das espécies passa a ser mais reconhecido.

De acordo com Egler (1999), durante décadas muitas das ideias sobre diversidade biológica estiveram relacionadas ao aumento dos conhecimentos sobre a existência de organismos diversos, assim como a valorização de ambientes que proporcionassem relaxamento e prazer de convívio com a natureza. Nota-se, assim, uma relação com o ambiente marcada por valores científicos, estéticos e recreativos.

A partir da segunda revolução industrial, com o rápido crescimento da apropriação dos recursos naturais, começou-se a notar a extinção de espécies e também de ambientes naturais. A partir daí há um aumento paulatino das ideias conservacionistas, que vão se acentuar no séc. XX. A predominância dos valores científicos e estéticos desse momento influenciaram o direcionamento das ações de conservação para a preservação de espécies carismáticas. Ainda no final do 
séc. XIX, nota-se a intensificação das ações de conservação com a criação de parques e áreas de preservação.

O aumento da preocupação com as questões sobre conservação refletemse na elaboração de uma série de convenções. A partir da metade do século XX ampliaram-se os espaços de discussão e outros atores sociais passaram a atuar efetivamente nestes debates. Ainda que a ciência tenha tido grande importância e atuado para a definição dos parâmetros e estruturação das políticas ambientais, outros grupos e interesses vêm pautando as ações, adaptações nas leis, fechamento de acordos, entre outras medidas.

De acordo com Egler (op. cit.) a percepção da biodiversidade passou a ser muito mais global a partir da década de 1980. Muitas das associações conservacionistas ampliaram seus objetivos e outras surgiram com os propósitos de integrar à conservação da biodiversidade demandas sociais (especialmente das comunidades locais e tradicionais), discutir a ética das novas tecnologias, repensar as relações entre nós e a natureza.

Nas últimas décadas nota-se uma evolução na percepção sobre o valor da biodiversidade. Os chamados serviços ambientais ou ecossistêmicos trazem novamente para o cerne das questões de conservação a utilidade da natureza para a vida humana. Ainda que abarque muitas das ideias que foram incorporadas aos paradigmas da conservação e desenvolvimento sustentável, há um forte apelo à valoração da biodiversidade como ferramenta para balizar as ações de conservação.

Nos museus de ciências, as questões ambientais são tratadas desde uma concepção classificatória da natureza, já presente nos gabinetes de curiosidades do século XVI, passando por uma visão ecológica até uma visão mais holística, quer ecossistêmica ou integradora (FORTIN-DEBART, 2003; PORCEDDA et al., 2006). Estas modificações tendem, nas perspectivas mais atuais, a uma maior inclusão do ser humano como agente e parte dos processos ambientais, e não apenas como parte constituinte biologicamente da natureza (GONZÁLEZ, GILPÉREZ e VILCHES, 2001; GIL-PÉREZ, VILCHES e GONZÁLEZ, 2002; VILCHES et al., 2006).

Considerando a importância atual das questões acerca da biodiversidade e conservação na sociedade, é importante conhecer os processos de 
recontextualização que ocorrem na produção de exposições e analisar as características dos discursos expositivos. Para isso, realizamos a análise dos discursos expositivos sobre biodiversidade de duas exposições quanto à complexidade dos conhecimentos e competências, e à forma de transmissão desses conhecimentos (relações entre discursos), relacionando-as com os objetivos e ideologias dos conceptores e instituições envolvidas no processo de recontextualização. Com isso, buscamos compreender como essas características e o posicionamento desses agentes e agências influenciou no nível de exigência dos conteúdos que aparecem expressos na mensagem dos discursos expositivos.

O conceito de "exigência conceptual" integra a complexidade do conhecimento científico e das capacidades cognitivas, as relações intradisciplinares e interdisciplinares que se traduzem na força das fronteiras dentro e entre diferentes disciplinas, e as relações entre conhecimentos acadêmicos e não acadêmicos que se traduzem também na força entre as fronteiras desses conhecimentos (MORAIS E NEVES, 2012). Este conceito foi inicialmente utilizado por Morais (1991) para estudar como o nível de exigência influencia a aquisição dos alunos. Atualmente, o conceito tem sido largamente aplicado nas pesquisas do grupo de Estudos Sociológicos de Sala de Aula (ESSA).

A ideia de complexidade conceitual na área de educação em ciências já vem sendo utilizada desde a década de 1970 e 1980 em trabalhos que associam funções cognitivas aos estágios de desenvolvimento propostos por Piaget (SHAYER e ADEY, 1981; ADEY, ROBERTSON e VENVILLE, 2002). De acordo com Morais e Neves (2012), a ideia de complexidade conceitual foi ampliada nos trabalhos desenvolvidos pelo ESSA, integrando trabalhos de outros autores. Assim, a complexidade dos conhecimentos científicos, que compõem o conceito de exigência conceptual, é baseada na distinção entre fatos, fatos generalizados, conceitos simples, conceitos complexos e teorias. Para Morais e Neves (op. cit.) a compreensão de conhecimentos complexos envolve a compreensão de conceitos simples e de fatos. Já os temas estruturantes, que correspondem às generalizações e teorias, abarcam explicações sobre uma variedade de fenômenos relacionados.

Vale lembrar que para Bernstein (1999) o conhecimento científico é um discurso vertical de estrutura hierárquica, havendo portanto, uma integração 
entre os conteúdos em um crescente nível de abstração. Com base no trabalho do autor, Morais e Neves (2012) propõem que se a educação científica reflete em parte a estrutura do conhecimento científico, ela deverá levar à compreensão de conceitos e ideias mais amplas, ainda que isso necessite de um equilíbrio entre conhecimentos de níveis distintos de complexidade.

A complexidade das capacidades ou competências cognitivas, segundo Morais e Neves (op. cit.) também integram o conceito de "exigência conceptual". 0 processo de ensino e aprendizagem deve incluir capacidades complexas, como a compreensão, aplicação e avaliação, além das capacidades simples, como a memorização. As autoras apontam que além da importância intrínseca do desenvolvimento das capacidades cognitivas complexas, elas são essenciais para a aprendizagem de conhecimentos científicos de nível elevado.

As autoras destacam ainda o papel da prática para a aprendizagem de conhecimentos de elevado nível de exigência. De acordo com Vigotsky (1996), a educação deve ir além do nível cognitivo dos alunos. Isso significa que o nível de complexidade dos conhecimentos postos em prática deve ser mais elevado do que nível cognitivo que os alunos poderiam atingir sozinhos, operando assim nas chamadas zonas de desenvolvimento proximal. Isso reforça a importância da mediação em diferentes contextos de ensino-aprendizagem, tais como os museus e exposições, e indica para a promoção de conhecimentos de diferentes níveis de complexidade neste processo.

Dependendo do posicionamento ideológico e pedagógico dos agentes que atuam nos processos de recontextualização, o nível de conhecimento poderá ser rebaixado, com a justificativa de incluir os indivíduos mais desfavorecidos socialmente. Por outro lado, ao se considerar a diversidade sociocultural e que todos os indivíduos possuem possibilidades de adquirir conhecimento científico mais complexo, pode-se facilitar aos menos favorecidos o acesso à estrutura hierárquica do conhecimento, privilegiado pela comunidade científica e pelos grupos de poder na sociedade (MORAIS, NEVES e FERREIRA, 2014).

Analogamente a esse processo, é interessante destacar a heterogeneidade de públicos que os museus e instituições culturais recebem, além do importante papel social desses espaços para a democratização do acesso à cultura. Assim como existe um conjunto de conhecimentos científicos privilegiados, há também 
uma cultura elitizada que é legitimada pela escola, museus e instituições congêneres (BOURDIEU e DARBEL, 2003), por meio das mensagens presentes nos discursos expositivos.

Assim, por meio desta análise, pretendemos responder às seguintes perguntas: Quais são as características dos discursos expositivos? Qual a complexidade dos conteúdos e competências presentes neles? Como conceitos, competências e relações contribuem para essa complexidade? Como a mensagem reflete as intenções e objetivos dos agentes envolvidos na produção?

Os resultados a essas questões poderão evidenciar o potencial das exposições analisadas em promover, a seus visitantes, o acesso a conteúdos relacionados à biodiversidade e conservação de maior complexidade. Tais resultados podem evidenciar ainda, como as relações de poder e controle influenciaram as mensagens presentes nesses discursos.

\subsection{Análise dos resultados}

Apresentamos no primeiro item, a seguir, aspectos gerais sobre as exposições estudadas. Nas tabelas são apresentados os módulos expositivos, de acordo com as temáticas tratadas, os elementos expositivos presentes neles e o número de unidades de análise.

No item subsequente são apresentados os resultados da aplicação dos diferentes instrumentos de análise utilizados para caracterizar o "que" e o "como" do discurso expositivo. 0 item final apresenta a discussão dos resultados.

\subsubsection{A "Estufa do Cerrado"}

Como apresentamos anteriormente, a exposição de longa duração "Estufa do Cerrado" está localizada no Jardim Botânico de São Paulo. A área expositiva é de aproximadamente $360 \mathrm{~m}^{2}$, com proposta imersiva, em que são integrados elementos vivos, outros objetos e aparatos expositivos. Como tal, a exposição conta com uma área destinada à reprodução do ambiente natural do Cerrado e demais áreas com aparatos expositivos diversos, tais como painéis com textos e imagens, vídeos, interativos, vitrines com espécies preservadas, entre outros.

0 tema central da exposição é o bioma do Cerrado. Presente em grande parte do interior do Estado de São Paulo e região central do Brasil, o Cerrado 
figura hoje entre as áreas de maior importância para a conservação no mundo, pois possui grande número de espécies endêmicas e perdeu pelo menos metade da sua área de cobertura original.

Dividimos a exposição em oito módulos, com base nos aspectos e subtemáticas apresentadas. As principais características dos módulos estão resumidos na tabela 4.1 e na figura 4.1, na qual apresentamos um panorama da exposição, com imagens dos módulos e localização deles na planta baixa da exposição.

Tabela 4.1: Características temáticas e expográficas da "Estufa do Cerrado”

\begin{tabular}{|c|c|c|c|c|}
\hline Módulo & $\begin{array}{l}\text { Título/ } \\
\text { subtema }\end{array}$ & $\begin{array}{l}\text { Principais conteúdos } \\
\text { tratados }\end{array}$ & $\begin{array}{l}\text { Principais elementos } \\
\text { expográficos }\end{array}$ & $\begin{array}{l}\text { No de } \\
\text { unidades } \\
\text { de análise }\end{array}$ \\
\hline 1 & Introdução & $\begin{array}{l}\text { Caracterização geral do } \\
\text { bioma e dos assuntos } \\
\text { tratados na exposição }\end{array}$ & Painel com texto & 4 \\
\hline 2 & $\begin{array}{l}\text { Savanas } \\
\text { no } \\
\text { Mundo }\end{array}$ & $\begin{array}{l}\text { Localização das Savanas } \\
\text { no mundo. Principais } \\
\text { características do Cerrado. }\end{array}$ & $\begin{array}{l}\text { Painéis com texto e painel } \\
\text { basculante com mapas e } \\
\text { imagens. }\end{array}$ & 8 \\
\hline 3 & Clima & $\begin{array}{l}\text { Precipitação no Cerrado } \\
\text { em comparação com mata } \\
\text { atlântica. }\end{array}$ & $\begin{array}{l}\text { Painel com texto e interativo } \\
\text { push-button }\end{array}$ & 2 \\
\hline 4 & Fisionomias & $\begin{array}{l}\text { Aspectos de morfologia, } \\
\text { fauna e flora das várias } \\
\text { fisionomias do Cerrado. }\end{array}$ & $\begin{array}{l}\text { Reprodução do ambiente } \\
\text { natural com espécies } \\
\text { naturais de flora, elementos } \\
\text { de fauna, painéis e placas } \\
\text { com textos e imagens. }\end{array}$ & 23 \\
\hline 5 & Fogo & $\begin{array}{l}\text { Como o fogo atua no } \\
\text { Cerrado. }\end{array}$ & Painéis com texto e vídeo. & 11 \\
\hline 6 & Solo & $\begin{array}{l}\text { Principais características } \\
\text { dos solos do Cerrado. }\end{array}$ & $\begin{array}{l}\text { Interativo push-button com } \\
\text { vitrine de solos. Painéis com } \\
\text { texto. }\end{array}$ & 3 \\
\hline 7 & $\begin{array}{l}\text { Interação } \\
\text { fogo e solo }\end{array}$ & $\begin{array}{l}\text { Como a incidência do fogo } \\
\text { e características do solos } \\
\text { interagem na formação de } \\
\text { paisagens. }\end{array}$ & $\begin{array}{l}\text { Interativo de múltipla } \\
\text { escolha e painel com texto. }\end{array}$ & 10 \\
\hline 8 & $\begin{array}{l}\text { Conservação e } \\
\text { biodiversidade }\end{array}$ & $\begin{array}{l}\text { Importância da } \\
\text { conservação do Cerrado. } \\
\text { Aspectos que levam a } \\
\text { perda de habitat. } \\
\text { Biodiversidades da fauna, } \\
\text { flora, aspectos humanos. }\end{array}$ & $\begin{array}{l}\text { Painéis com texto e } \\
\text { interativo com painéis } \\
\text { basculantes imagem e texto. }\end{array}$ & 32 \\
\hline
\end{tabular}




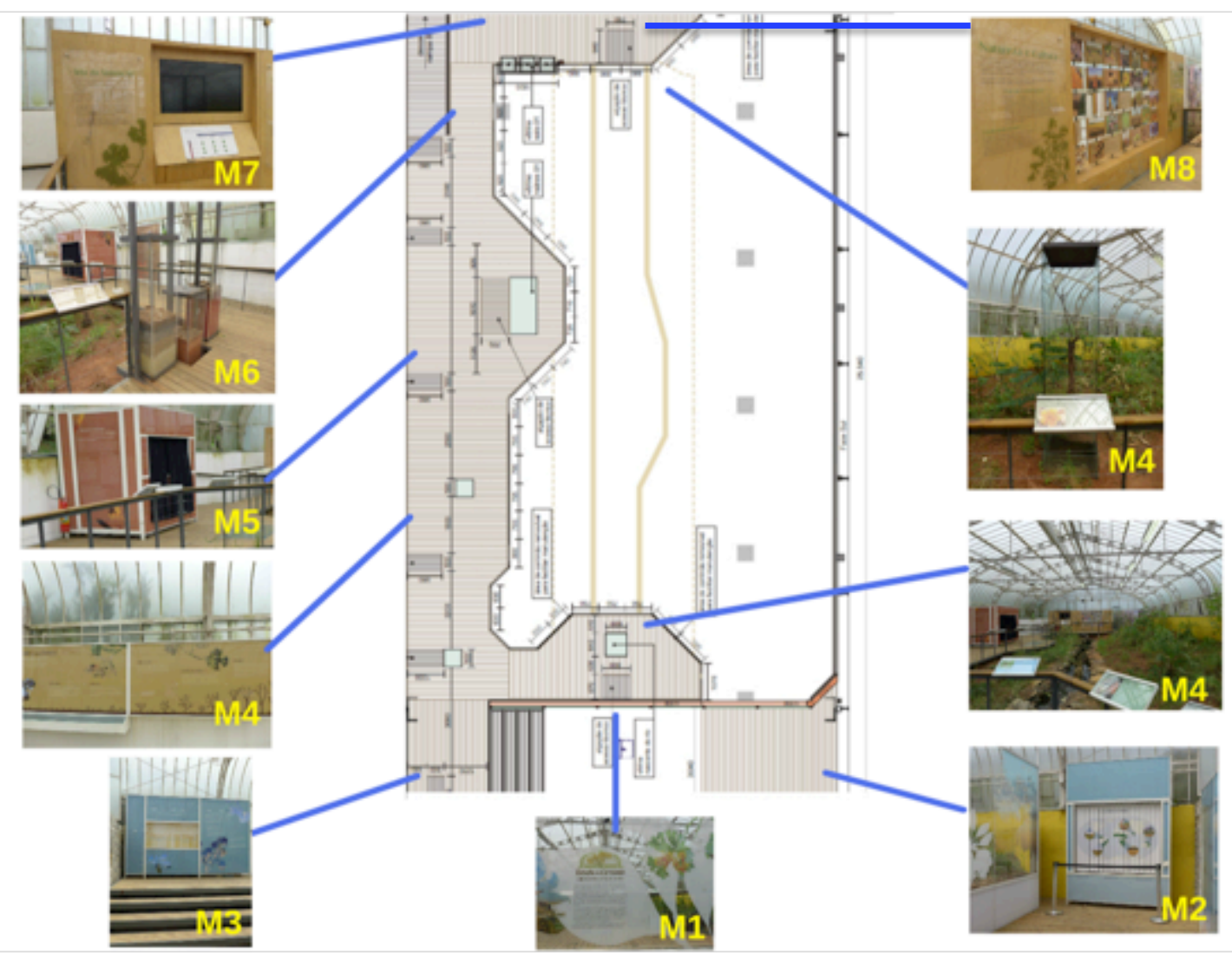

Figura 4.1: Planta baixa da exposição "Estufa do Cerrado" com localização dos oito módulos.

\subsubsection{A "Estufa da Caatinga Mineira"}

A exposição de longa duração "Estufa da Caatinga Mineira" está sediada na Fundação Zoo-botânica de Belo Horizonte (FZB-BH), na área do Jardim Botânico. Na área do Jardim Botânico há cinco estufas, três delas apresentam alguns dos biomas existentes no estado de Minas Gerais - campos rupestres, mata atlântica e caatinga, e as outra duas trabalham conceitos de evolução dos vegetais. A "Estufa da Caatinga Mineira” possui $158 \mathrm{~m}^{2}$ e assim como a "Estufa do Cerrado", possui expografia imersiva. A exposição conta com espécies da Caatinga organizadas de forma a recriar o ambiente natural, painéis com textos e imagens, objetos, entre outros.

Como tema central, a exposição apresenta o bioma da Caatinga, especificamente das áreas em que ocorre no estado de Minas Gerais. Tal bioma 
ocupa cerca de 10\% do território brasileiro, possui alto índice de endemismo, mas carece de estudos acerca do seu patrimônio biológico, que vem sendo dilapidado com o avanço do desmatamento.

Dividimos a exposição em seis módulos, com base nos aspectos apresentados. As principais características de cada módulo estão resumidas na tabela 4.2 e na figura 4.2, que possui um panorama da exposição, com imagens dos módulos e localização deles na planta baixa das exposições.

Tabela 4.2: Características temáticas e expográficas da "Estufa do Caatinga Mineira"

\begin{tabular}{|c|c|c|c|c|}
\hline Módulo & Título/subtema & $\begin{array}{l}\text { Principais conteúdos } \\
\text { tratados }\end{array}$ & $\begin{array}{l}\text { Principais elementos } \\
\text { expográficos }\end{array}$ & $\begin{array}{l}\text { No de } \\
\text { unidades } \\
\text { de análise }\end{array}$ \\
\hline 1 & Introdução & $\begin{array}{l}\text { Caracterização geral do } \\
\text { bioma e dos assuntos } \\
\text { tratados na exposição }\end{array}$ & Painel com texto & 1 \\
\hline 2 & A Caatinga & $\begin{array}{l}\text { Aspectos sobre o clima e } \\
\text { características da } \\
\text { Caatinga na época seca e } \\
\text { úmida }\end{array}$ & $\begin{array}{l}\text { Reprodução do ambiente } \\
\text { natural com espécies vivas } \\
\text { da flora, elementos de } \\
\text { fauna, placas com textos e } \\
\text { imagens. }\end{array}$ & 3 \\
\hline 3 & O sertanejo & $\begin{array}{l}\text { Cultura dos habitantes } \\
\text { da caatinga mineira }\end{array}$ & $\begin{array}{l}\text { Imersão com elementos } \\
\text { culturais, objetos e placas } \\
\text { com textos e imagens. }\end{array}$ & 5 \\
\hline 4 & $\begin{array}{l}\text { Adaptações e } \\
\text { espécies }\end{array}$ & $\begin{array}{l}\text { Tipos de adaptação para } \\
\text { a seca; exemplos de } \\
\text { espécies da fauna e flora. }\end{array}$ & Placa com texto e imagem. & 9 \\
\hline 5 & Paisagem & $\begin{array}{l}\text { Aspectos morfológicos e } \\
\text { das fitofisionomias da } \\
\text { caatinga do norte e } \\
\text { nordeste de minas. }\end{array}$ & $\begin{array}{l}\text { Reprodução do ambiente } \\
\text { natural com espécies } \\
\text { naturais, painéis com } \\
\text { imagens, placas com } \\
\text { textos e imagens. }\end{array}$ & 4 \\
\hline 6 & $\begin{array}{l}\text { Ameaças } \mathrm{e} \\
\text { conservação }\end{array}$ & $\begin{array}{l}\text { Exemplos das principais } \\
\text { ameaças e estratégias } \\
\text { para a conservação da } \\
\text { caatinga }\end{array}$ & $\begin{array}{l}\text { Placas com texto e } \\
\text { imagem. }\end{array}$ & 2 \\
\hline
\end{tabular}




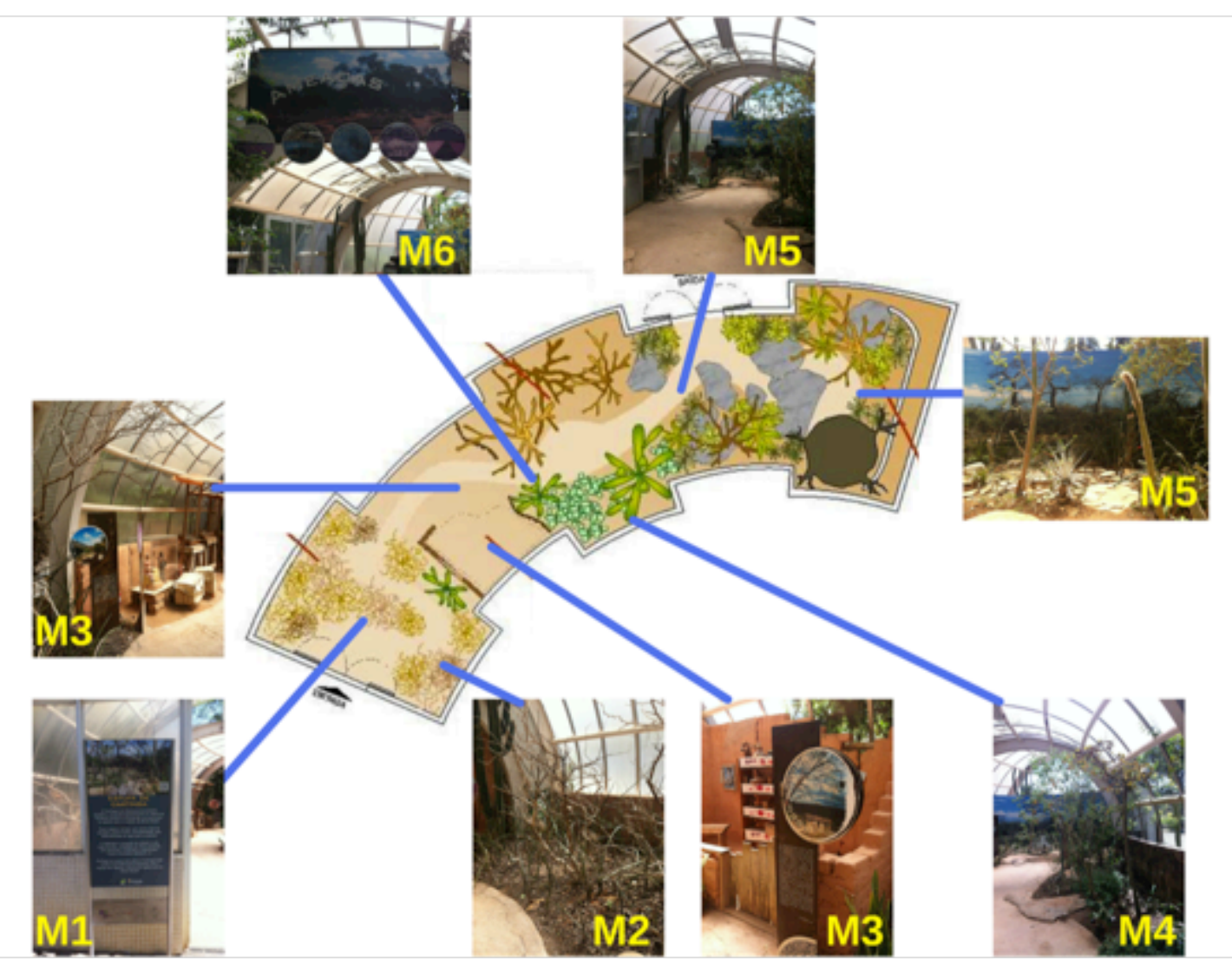

Figura 4.2: Planta baixa da exposição "Estufa da Caatinga Mineira" com localização dos seis módulos.

\subsubsection{Complexidade dos conhecimentos e competências relacionados à biodiversidade - o "que" do discurso}

Foram analisadas 93 unidades presentes na exposição "Estufa do Cerrado" e 24 unidades na "Estufa da Caatinga Mineira" quanto à complexidade dos conhecimentos e das competências relacionados à biodiversidade.

No que se refere ao "que" do discurso, conhecimentos científicos e competências cognitivas, cada unidade de análise foi categorizada conforme o grau de complexidade, variando de 1 a 4 , sendo 1 o menos complexo e 4 aquele que apresenta maior complexidade, conforme a descrição realizada no capítulo 2, quadros 2.1 e 2.2 .

As figuras de 4.3 a 4.6 mostram exemplos de unidades dos diferentes graus de complexidade dos conhecimentos e competências. Conforme explicitamos no capítulo 2, após a categorização, foi calculada a frequência de cada grau no conjunto das unidades (total) e por módulo. Os resultados relacionados às frequências dos diferentes graus de complexidade são 
apresentados no item Os graus de complexidade dos conhecimentos e competências.

Vale lembrar que as unidades de análise foram categorizadas de acordo com o grau mais alto identificado, ainda que seja possível uma mesma unidade apresentar características de menor complexidade. A mesma unidade pode também apresentar mais de uma característica do grau em que foi categorizada. Por exemplo, uma unidade de grau 2 pode ter características como "fatos relacionados" e também "definição de conceitos" (figura 4.3). Da mesma forma que ocorre em relação às características dos conhecimentos, uma mesma unidade de análise pode apresentar mais de um verbo de ação das competências, como mostra a figura 4.3, em que a unidade apresenta os verbos distinguir e comparar.

Em busca de compreender quais são e com qual frequência as características dos conhecimentos e verbos de ação das competências estão presentes em cada grau, identificamos nas unidades de análise tais características e verbos (apenas para o grau mais elevado) e calculamos a frequência relativa delas. Os resultados dessa analise são apresentados no item As características definidoras dos conhecimentos e os verbos de ação das competências. 


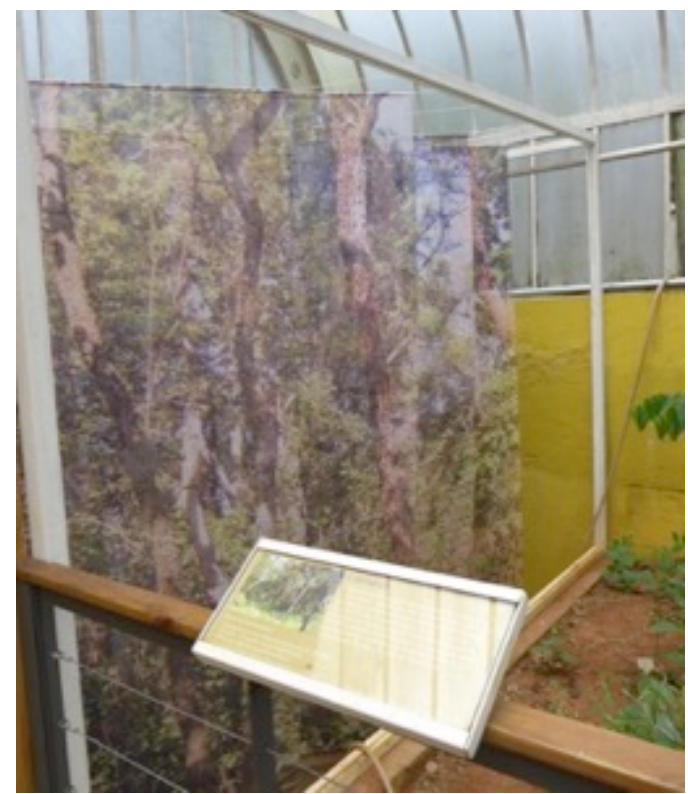

Figura 4.3: "Estufa do Cerrado", unidade 22, módulo 4.

Transcrição do texto na painel: "Cerradão- Chamado pelos índios tupi-guarani de catanduva - caa (mato), tan (fraco, ápero) e diba (árvore) -, o cerradão é a fisionomia mais adensada do Cerrado. As árvores são de maior porte e suas copas não chegam a se encostar, o que permite a penetração de luz."

- Complexidade dos conhecimentos: grau 2. Características definidoras: fatos relacionados e definição de conceito.

- Complexidade das competências: grau 3. Verbo de ação: distinguir, comparar.

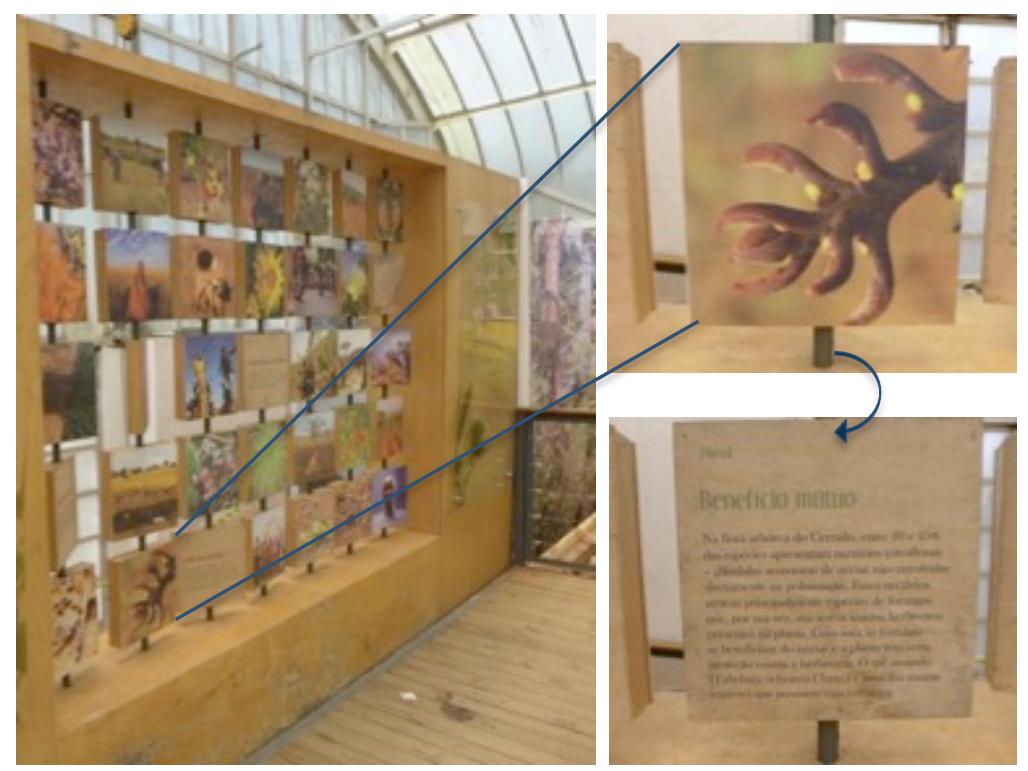

Figura 4.4: "Estufa do Cerrado", unidade 13, módulo 8.

Transcrição do texto do painel: "Benefício Mútuo - Na flora arbórea do Cerrado, entre 20 e 25\% das espécies apresentam nectários extraflorais - glândulas secretoras de néctar não envolvidas diretamente na polinização. Esses nectários atraem principalmente espécies de formigas que, por sua vez, atacam os insetos herbívoros presentes na planta. Com isso, as formigas se beneficiam do néctar e a planta tem certa proteção contra a herbivoria. 0 ipê amarelo (Tabebuia ochracea Cham.) é uma das muitas espécies que possuem essa estrutura."

- Complexidade dos conhecimentos: grau 3. Características definidoras: relação entre conceitos de nectário e mutualismo.

- Complexidade das competências: grau 3. Deduzir. 


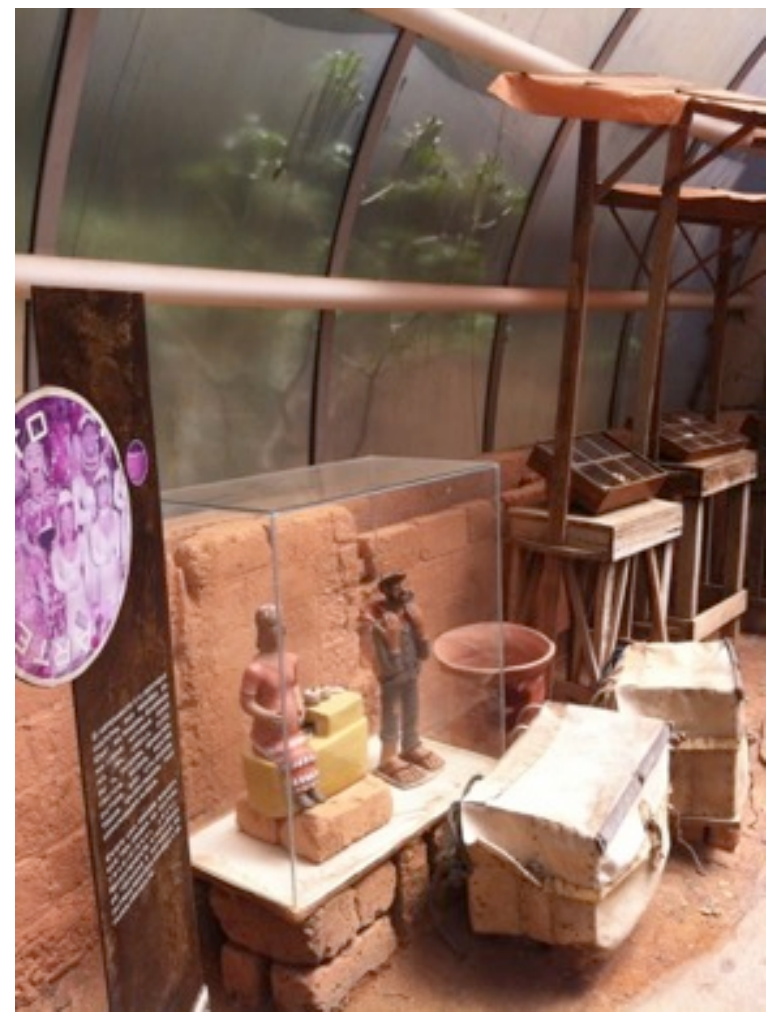

Figura 4.5: "Estufa da Caatinga Mineira”, unidade 1, módulo 2.

Transcrição do texto: "O artesanato é o destaque cultural das regiões da caatinga mineira. Diversos materiais naturais como madeira, cipó, palha, taquara, sementes, frutos, raízes, dentre outros são utilizados. Todos encontrados nas comunidades rurais."

- Complexidade dos conhecimentos: grau 1. Características definidoras: fatos isolados e exemplos - Complexidade das competências: grau 2. Ilustrar, retratar.

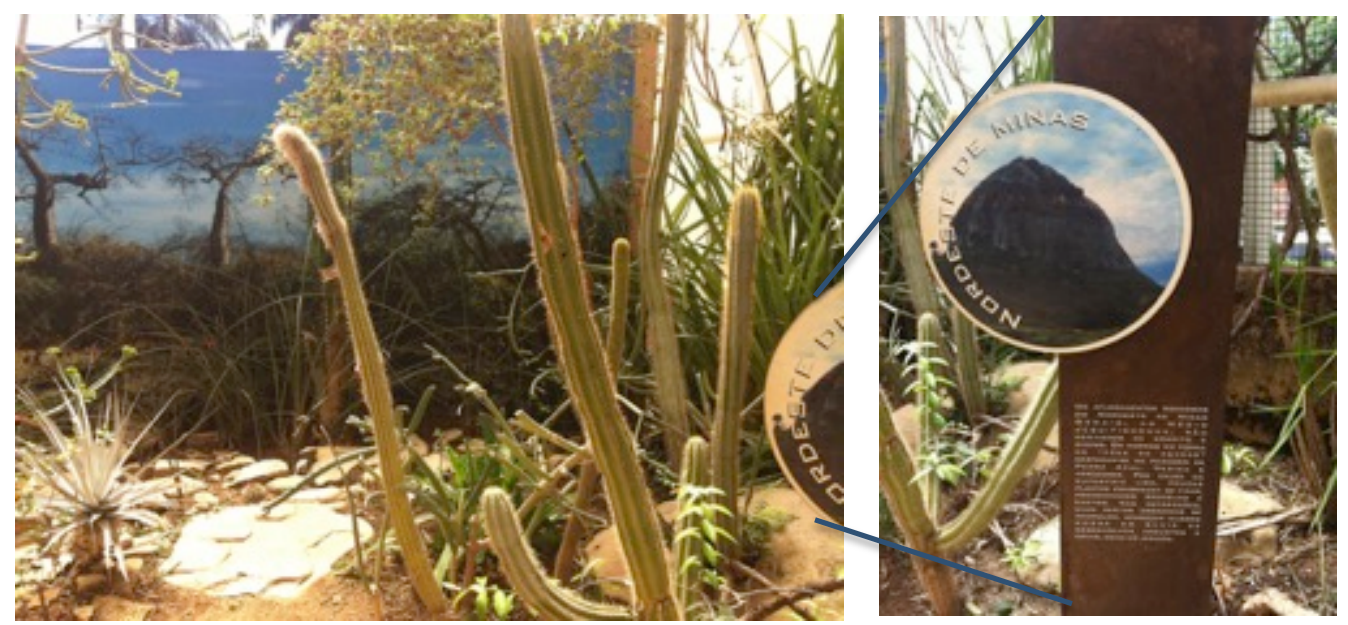

Figura 4.6: "Estufa da Caatinga Mineira”, unidade 3, módulo 5.

Transcrição do texto do painel: "Por causa da superfície lisa, poucas plantas conseguem se fixar, predominando bromélias e cactos. Nas depressões, onde restos orgânicos se acumulam, aparecem musgos sobre os quais se desenvolvem arbustos e ervas, como os Jericós."

- Complexidade dos conhecimentos: grau 2. Característica definidora: fatos relacionados.

- Complexidade das competências: grau 2. Verbos de ação: ilustrar, retratar. 
Os graus de complexidade dos conhecimentos e competências
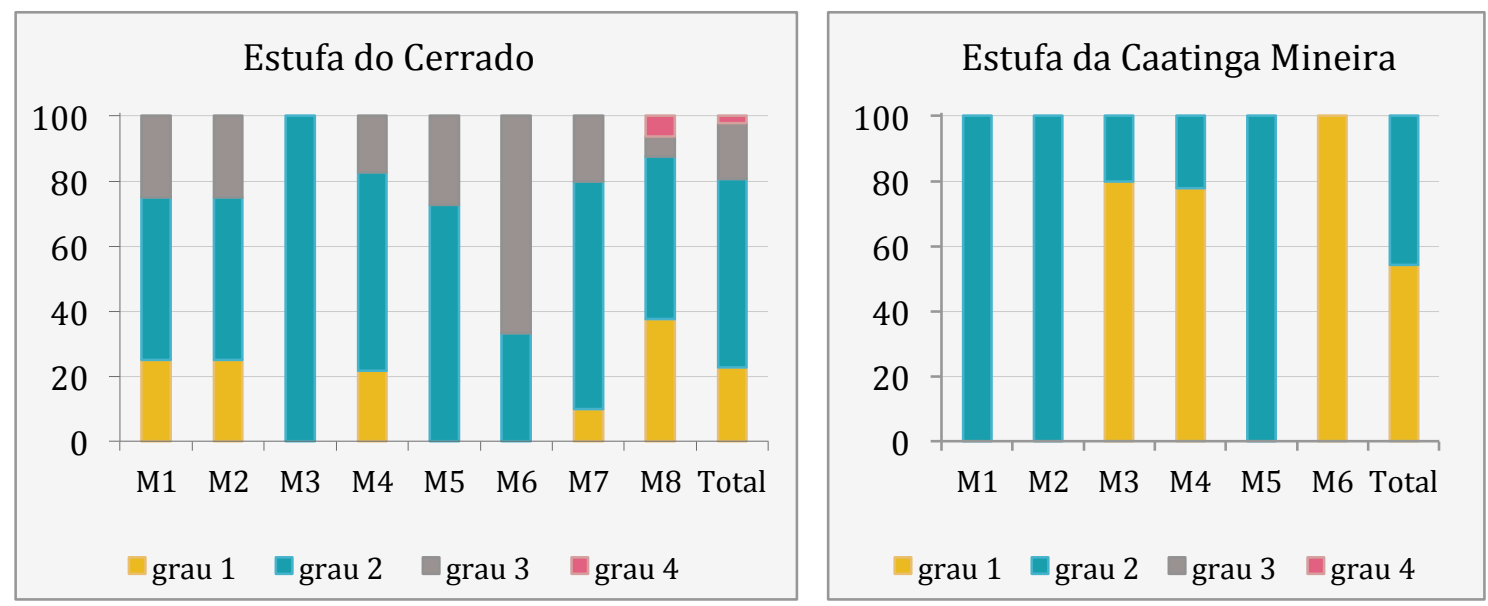

Figura 4.7 : Graus de complexidade dos conhecimentos. Porcentagem de unidades de análise nos diferentes graus em cada módulo e média da "Estufa do Cerrado" e "Estufa da Caatinga Mineira".

Na figura 4.7 nota-se que a distribuição dos graus de complexidade nos diferentes módulos das exposições não é homogênea, ocorrendo módulos que apresentam apenas um dos graus e outros que abrangem tanto conhecimentos mais simples quanto aqueles mais complexos.

Considerando o total de unidades de análise, nota-se que na exposição "Estufa do Cerrado" houve predomínio de unidades de análise com grau 2 de complexidade dos conhecimentos (58\%). As unidades de análise de grau 1 e grau 3 correspondem a $22,6 \%$ e $17,2 \%$ do total, respectivamente. Apenas 2,2\% das unidades analisadas são de grau 4. Já na exposição "Estufa da Caatinga Mineira as unidades de análise de grau 1 e 2 representam 54\% e 46\% respectivamente. Não foram categorizadas unidades nos graus 3 e 4.

Quanto à complexidade das competências, a figura 4.8 permite afirmar que assim como os conhecimentos, a distribuição das unidades de análise categorizadas nos diferentes graus de complexidade não é homogênea entre os módulos expositivos. Encontramos módulos em que a maioria das competências são de ordem mais simples de graus 1 e 2 , enquanto outros possuem graus 3 e 4 . 

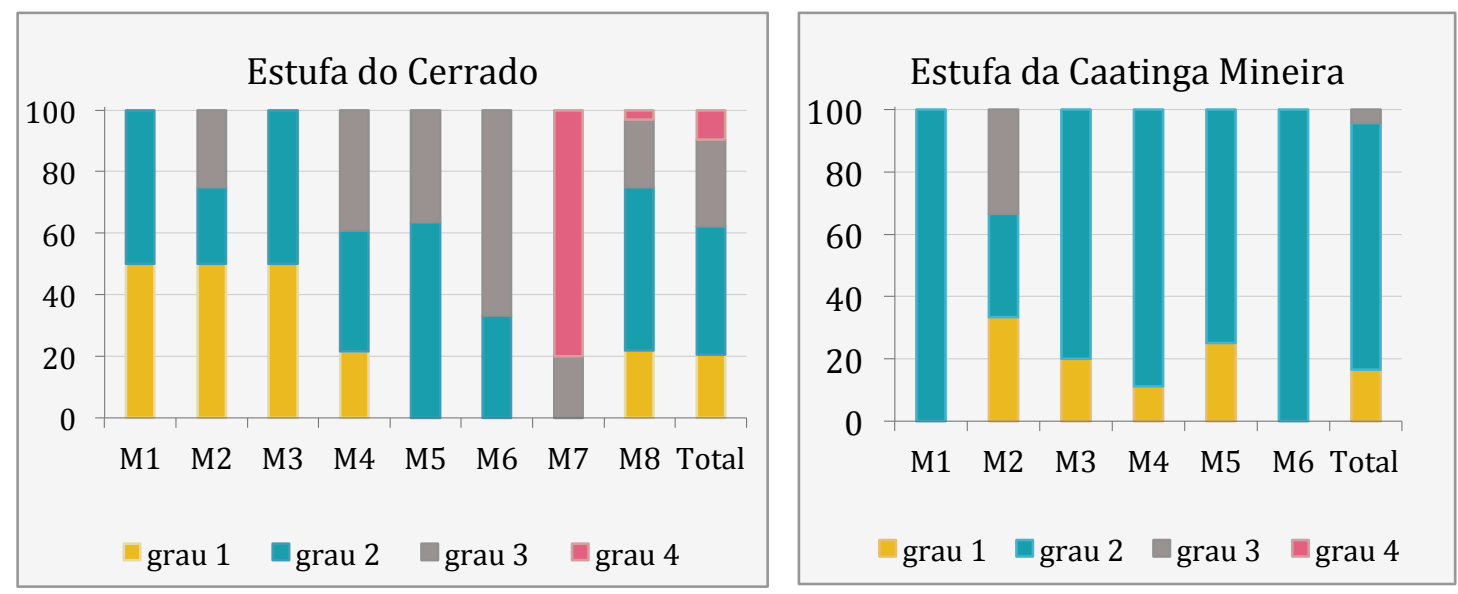

Figura 4.8: Graus de complexidade das competências. Porcentagem de unidades de análise nos diferentes graus em cada módulo da "Estufa do Cerrado" e "Estufa da Caatinga Mineira".

Dentre o total das unidades de análise presentes na exposição "Estufa do Cerrado", as de grau 2 são mais frequentes (42\%), em seguida as de grau 3 (28\%) e grau 1 (19\%). Apenas 9\% das unidades de análise foram categorizadas no grau 4. Na exposição "Estufa da Caatinga Mineira" predominaram as unidades de grau 2 (79\%). Em seguida aparecem as unidades de grau 1 (17\%) e de grau 3 (4\%). Não foram categorizadas unidades de grau 4.

As características definidoras dos conhecimentos e os verbos de ação das competências

Como dissemos anteriormente, além das frequências dos diferentes graus de complexidade no conjunto das unidades de análise, foram calculadas as frequências das características definidoras relacionadas a cada grau de complexidade dos conhecimentos. Na figura 4.9 as cores representam a frequência de cada grau no conjunto das unidades e o tamanho dos círculos representa a frequência das características definidoras de cada grau. Da mesma forma mostra a frequência e os verbos de ação relativos à complexidade das competências na "Estufa do Cerrado" e "Estufa da Caatinga Mineira", respectivamente. 


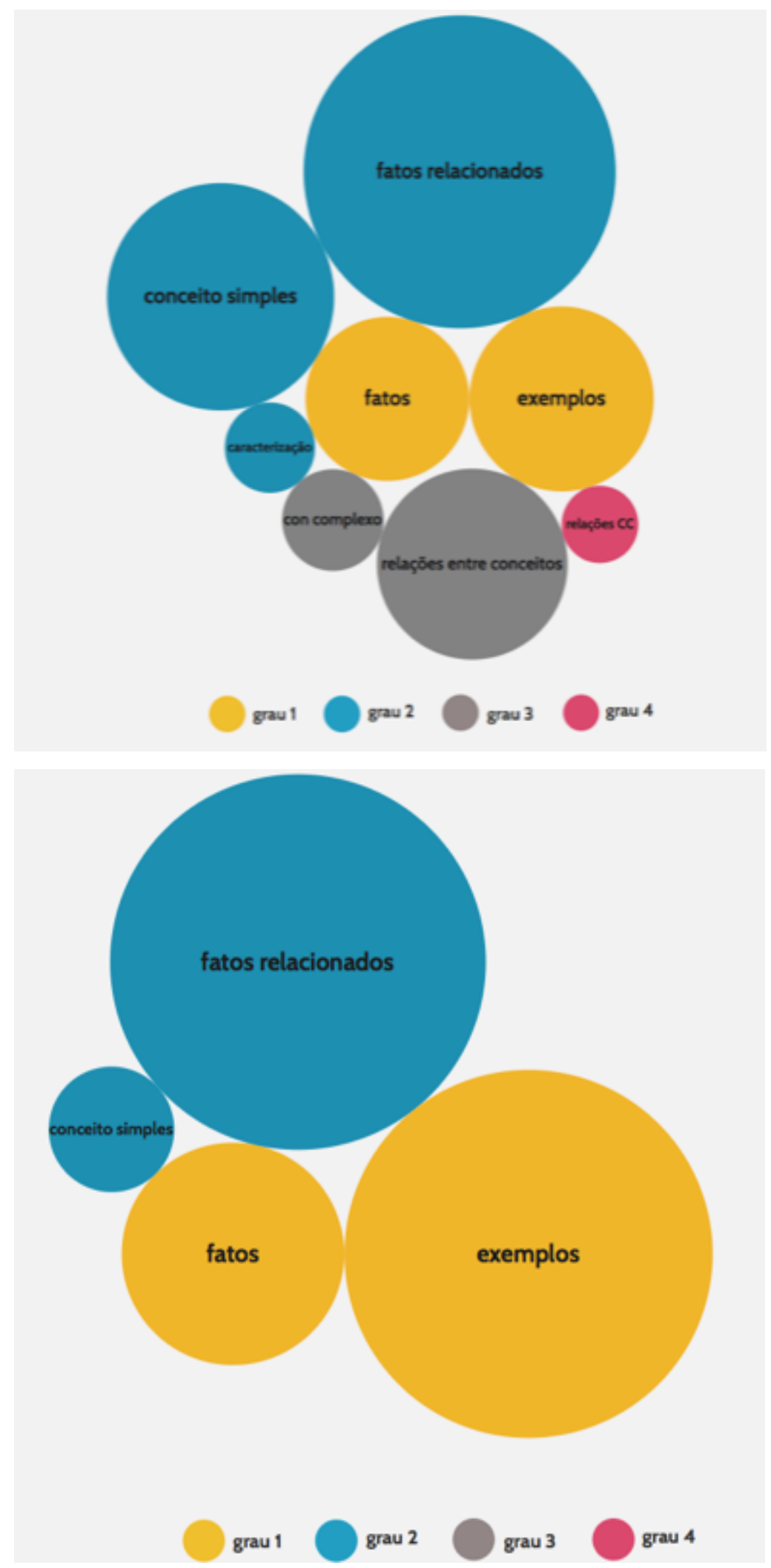

Figura 4.9: Descritores de conhecimentos. O tamanho das bolas mostra a proporção das características definidoras de cada grau de complexidade dos conhecimentos científicos presentes na "Estufa do Cerrado" e "Estufa da Caatinga Mineira". 
Na "Estufa do Cerrado", dentre as características definidoras das unidades de grau 2, os "fatos relacionados" são mais frequentes, seguidos pela "definição de conceitos" e "caracterização de fenômenos". A figura 4.3, apresentada anteriormente, mostra um exemplo de unidade de análise de grau 2. No caso da unidades de análise de grau 1, a "exemplificação" e os "fatos" têm frequência semelhante. As características mais presentes nas unidades de grau 3 foram as "relações entre diferentes conceitos", seguida pela "definição de conceitos complexos". Nas unidades de grau 4, as "relações entre conceitos complexos (relações CC)" ocorrem em todos os casos. A figura 4.10 traz um exemplo de unidade de análise de grau 4.

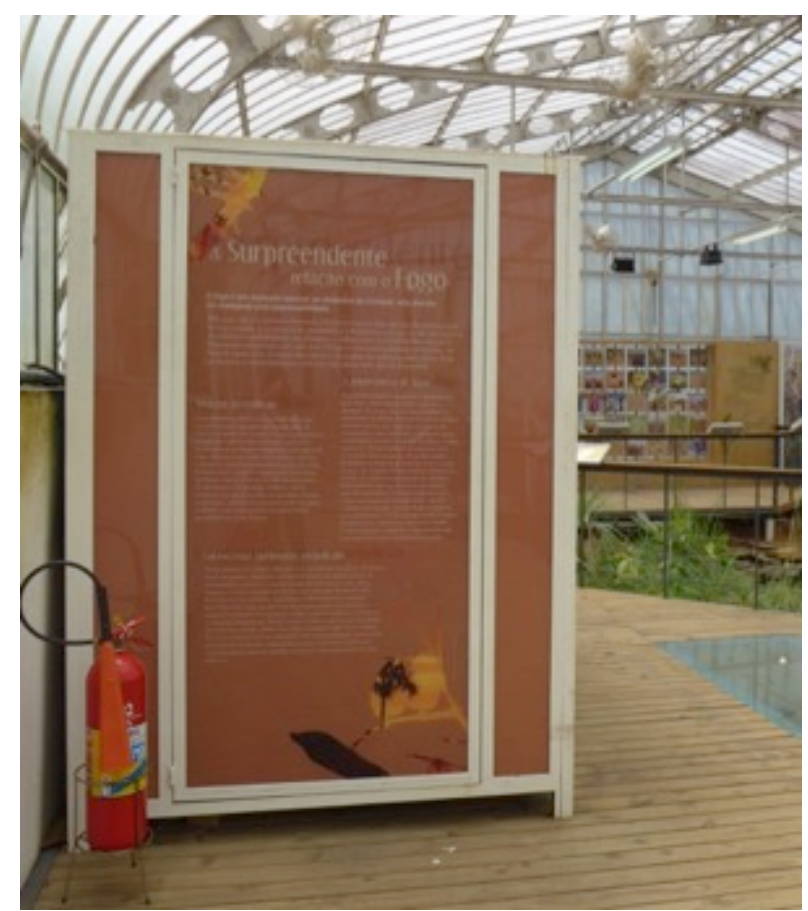

Figura 4.10: "Estufa do Cerrado", unidade 2, módulo 5.

Transcrição do texto do painel: "As queimadas podem ser provocadas por raios ou pelo homem (antrópicas) e fazem parte da história evolutiva do Cerrado. Como consequência, as espécies vegetais têm estruturas e processos fisiológicos de proteção e adaptação à passagem do fogo. Árvores, cujos caules têm cortiças isolantes espessas, e espécies que possuem gemas (de onde brotam ramos e folhas) e órgãos para armazenar nutrientes abaixo do nível do solo são exemplos de mecanismos de proteção. Folhas e outras estruturas das plantas podem ser perdidas durante a queimada, quando a temperatura pode alcançar os $800^{\circ} \mathrm{C}$, mas as partes vitais são preservadas, garantindo sua sobrevivência."

- Complexidade dos conhecimentos científicos: grau 4. Características definidoras: relações entre conceitos complexos.

Na exposição "Estufa da Caatinga Mineira", dentre as unidades de grau 1, os "exemplos" predominam, e em menor proporção aparecem os "fatos". Já entre 
as unidades de grau 2 há predomínio das características como "fatos relacionados", e uma frequência pequena de "definição de conceitos". A figura 4.11 mostram exemplos de unidades de análise de grau 1.



Figura 4.11: "Estufa da Caatinga Mineira”, unidade 5, módulo 4.

Transcrição do texto do painel: "Cardeal ou galo-da-campina - Paroaria dominicana; Periquitoda-caatinga ou jandaia-da-caatinga - Aratinga cactorum."

- Complexidade dos conhecimentos: grau 1. Característica definidora: exemplos de fauna.

A análise dos conteúdos presentes em cada tipo de descritor mostrou que os "fatos relacionados" tratam das características dos ambientes, das espécies ou das relações entre eles. Já entre "conceitos simples" estão aqueles relacionados à ecologia, como riqueza, nicho, ecótono e endemismo. Além disso, há também conceitos botânicos como fotoperíodo, sistemas radiculares e nectário. Nas unidades de análise de grau 3, a "relação entre conceitos" é caracterizada principalmente pela relação entre os conceitos ecológicos e o ambiente físico, como por exemplo a relação entre fisionomias e clima. Há ainda dentre as "relações entre conceitos", aquelas estabelecidas entre conceitos simples, por exemplo a relação entre riqueza e abundância. Os "conceitos complexos" são encontrados em poucas unidades de análise, mas são em geral, conceitos que abrangem um maior números de áreas de conhecimento tal como, o conceito de Domínio Fitogeográfico. Já nas unidades de análise de grau 4, as "relações entre conceitos complexos" estabelecem a ligação entre conceitos de diversidade composicional, perda de hábitat e serviços ambientais e culturais.

À semelhança do que foi apresentado sobre as características definidoras da complexidade dos conhecimentos, a figura 4.12 mostra a frequência dos 
verbos de ação relativos a cada grau de complexidade das competências. As cores representam cada grau de complexidade e o tamanho dos círculos representa a frequência dos verbos de ação de cada grau.

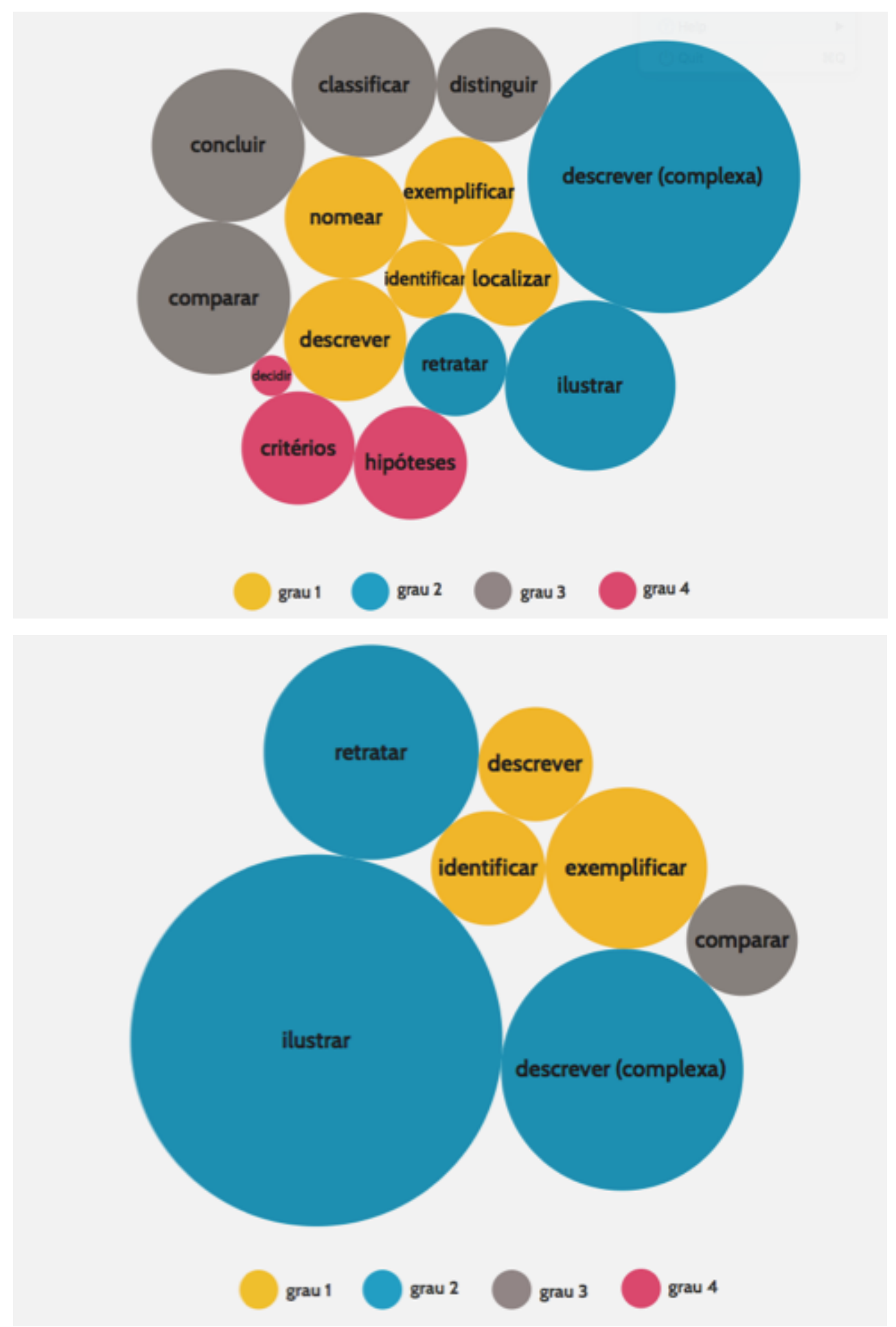

Figura 4.12: Verbos de ação das competências. Proporção dos diferentes verbos de ação relacionados a cada grau de complexidade das competências, presentes nas exposições "Estufa do Cerrado" e "Estufa da Caatinga Mineira". 
$\mathrm{Na}$ "Estufa do Cerrado", dentre as competências de compreensão do conhecimento - grau 2, predominaram a "descrição complexa" (descrever elementos-chave, como ou porquê), seguida daquelas de representação simbólica da informação, tais como "ilustrar" e "retratar ou representar". No que se refere às competências de análise do conhecimento - grau 3, foram mais comuns os verbos de ação "comparar" e "classificar", seguidos por "concluir" e "distinguir". Nas unidades de grau 1, dentre as competências relacionadas à recuperação do conhecimento, ocorreram a "descrição simples", "nomeação" e "exemplificação". Com menor frequência, ocorreram as competências de reconhecimento da informação, representadas pelos verbos de ação "localizar" e "identificar". As unidades categorizadas no grau 4 apresentaram, dentre as competências de utilização do conhecimento, a "formulação de hipóteses" e "estabelecimento de critérios" foram mais frequentes que a "tomada de decisão". As figuras 4.13 e 4.14 trazem exemplos de unidades de análise dos graus 3 e 4, respectivamente.
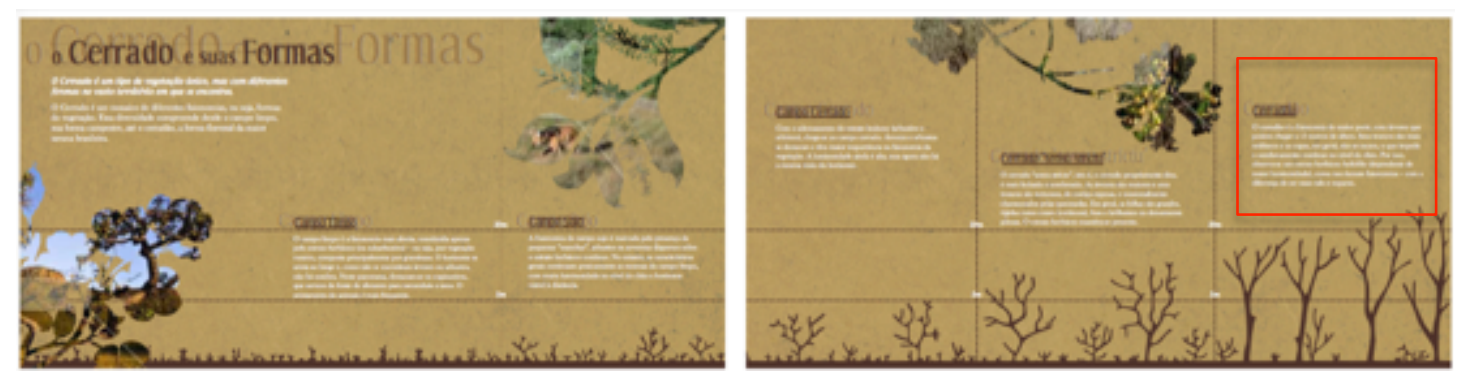

Figura 4.13: "Estufa do Cerrado", unidade 6, módulo 4.

Transcrição do texto circulado em vermelho no painel: "O cerradão é a fisionomia de maior porte, com árvores que podem chegar a 15 metros de altura. Seus troncos são mais retilíneos e as copas, em geral, não se tocam, o que impede o sombreamento contínuo no nível do chão. Por isso, observa-se um estrato herbáceo heliófilo (dependente de maior luminosidade), como nas demais fisionomias - com a diferença de ser mais ralo e esparso."

- Complexidade das competências: grau 3. Verbos de ação: distinguir a fisionomia no infográfico, inferir que "Cerrado" é a categoria mais ampla, comparação entre fisionomias. 


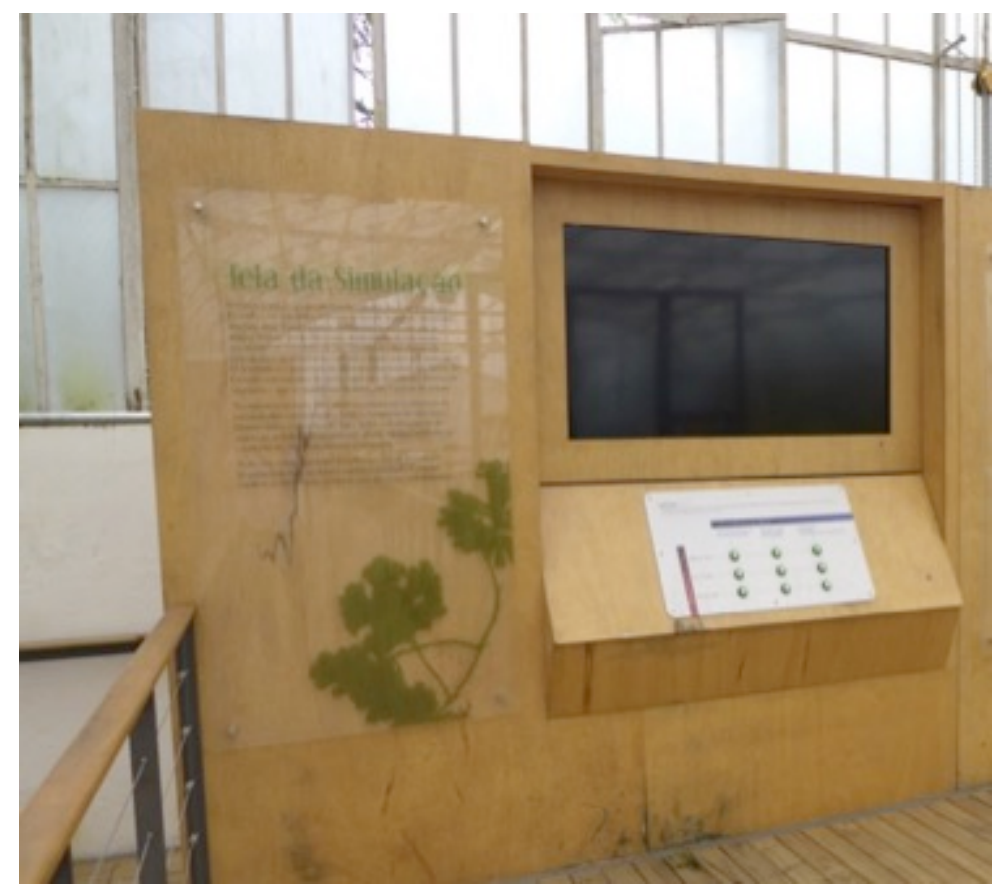

Figura 4.14: "Estufa do Cerrado", unidade 1, módulo 7.

Transcrição do texto do painel: "No interativo ao lado, você observa exatamente a influência da interação dos condicionantes sobre a fisionomia de uma área. Quanto maior a presença de fogo, maior o deslocamento da vegetação mais fechada para a mais aberta. Quanto melhores as condições do solo, mais densa é a fisionomia. Teste esse comportamento! Comece escolhendo um tipo de terreno, depois eleja a frequência com que o fogo agiria sobre a região e confira o resultado. Compare também as fisionomias resultantes em diferentes combinações."

- Complexidade das competências: grau 4. Verbos de ação: estabelecimento de critérios e teste de hipótese.

Já na "Estufa da Caatinga Mineira", dentre as unidades de grau 2 há predomínio das competências de representação simbólica da informação, com as ações "ilustrar" e "retratar ou representar", conforme exemplificado nas figuras 4.5, 4.6 e 4.16. Há ainda as competências de compreensão do conhecimento, representadas pela "descrição complexa". No que se refere às competências de recuperação do conhecimento - grau 1, a "exemplificação" foi mais frequente, seguida da "descrição simples". Ainda nas unidades de grau 1, encontramos as competências de reconhecimento da informação representadas nessa exposição, pelo verbo de ação "identificar". O verbo de ação "comparar", referente às competências de análise do conhecimento que definem o grau 3, está presente em $100 \%$ das unidades desse grau, a figura 4.15 traz um exemplo de comparação. Não foram caracterizadas outras ações relacionadas à análise dos conhecimentos. 


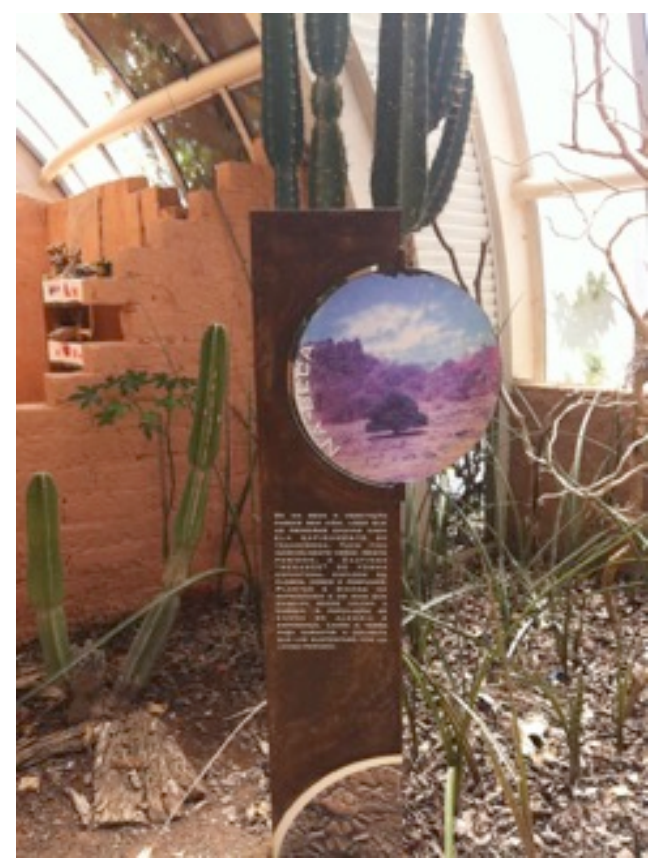

Figura 4.15: "Estufa da Caatinga Mineira", unidade 2, módulo2.

Transcrição do texto do painel: "Se na seca a vegetação parece sem vida, logo que as primeiras chuvas caem ela rapidamente se transforma. Tudo fica incrivelmente verde. Neste período, a caatinga renasce de forma espantosa, explode em flores, cores e perfumes. Plantas e bichos se reproduzem e os rios que estavam secos voltam a correr."

- Complexidade das competências: grau 3. Verbos de ação: comparação da fisionomia da caatinga em diferentes situações climáticas por meio da ilustração e texto.

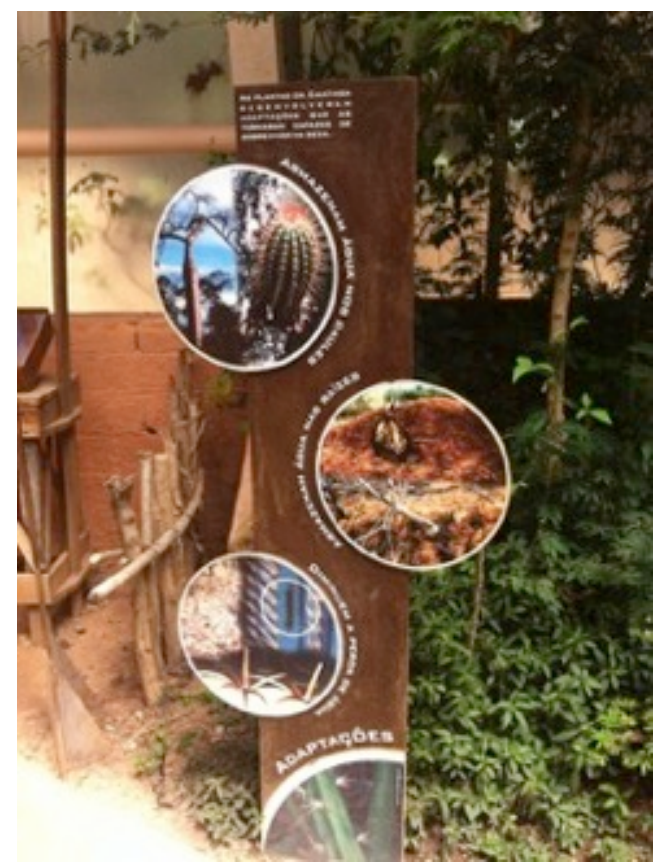

Figura 4.16: "Estufa da Caatinga Mineira", unidade 2, módulo2.

Transcrição do texto do painel: "As plantas da caatinga desenvolveram adaptações que as tornaram capazes de sobreviver na seca. Armazenam água nos caules. Armazenam água nas raízes. Diminuem a perda de água."

- Complexidade das competências: grau 2. Verbos de ação: imagem permite ilustrar as adaptações. 
Índices de complexidade dos conhecimentos e competências

$\mathrm{Na}$ figura 4.17 são apresentados os índices de complexidade dos conhecimentos e competências calculados para cada módulo e total. 0 cálculo do índice foi apresentado no item de tratamento de dados.

Com base nos resultados apresentados nas figuras 4.1 e 4.17, é possível afirmar que a complexidade dos conhecimentos, de acordo com a escala concebida, é maior na exposição "Estufa do Cerrado". A complexidade das competências também é maior nessa exposição, conforme os resultados das figuras 4.2 e 4.17.

Os índices totais mostram que em ambas as exposições a complexidade das competências cognitivas é maior do que a complexidade dos conhecimentos científicos. Na "Estufa do Cerrado" o índice total das competências é 0,5 enquanto na "Estufa da Caatinga Mineira" é de 0,4. Quanto às competências, o índice de complexidade é de 0,57 e 0,47, respectivamente.

$\mathrm{Na}$ "Estufa do Cerrado" os índices de complexidade dos conhecimentos são maiores nos módulos iniciais, enquanto os de complexidade das competências têm valores mais elevados nos módulos finais. De forma geral, nessa exposição, a complexidade das competências tende a aumentar ao longo da exposição, excluindo o módulo 8. Já a complexidade dos conhecimentos não apresenta um padrão. Na "Estufa da Caatinga Mineira", os índices de complexidade das competências são semelhantes ao longo da exposição e, excluindo o módulo 5, apresentam valores mais elevados que os índices de complexidade dos conhecimentos em todos os módulos. 


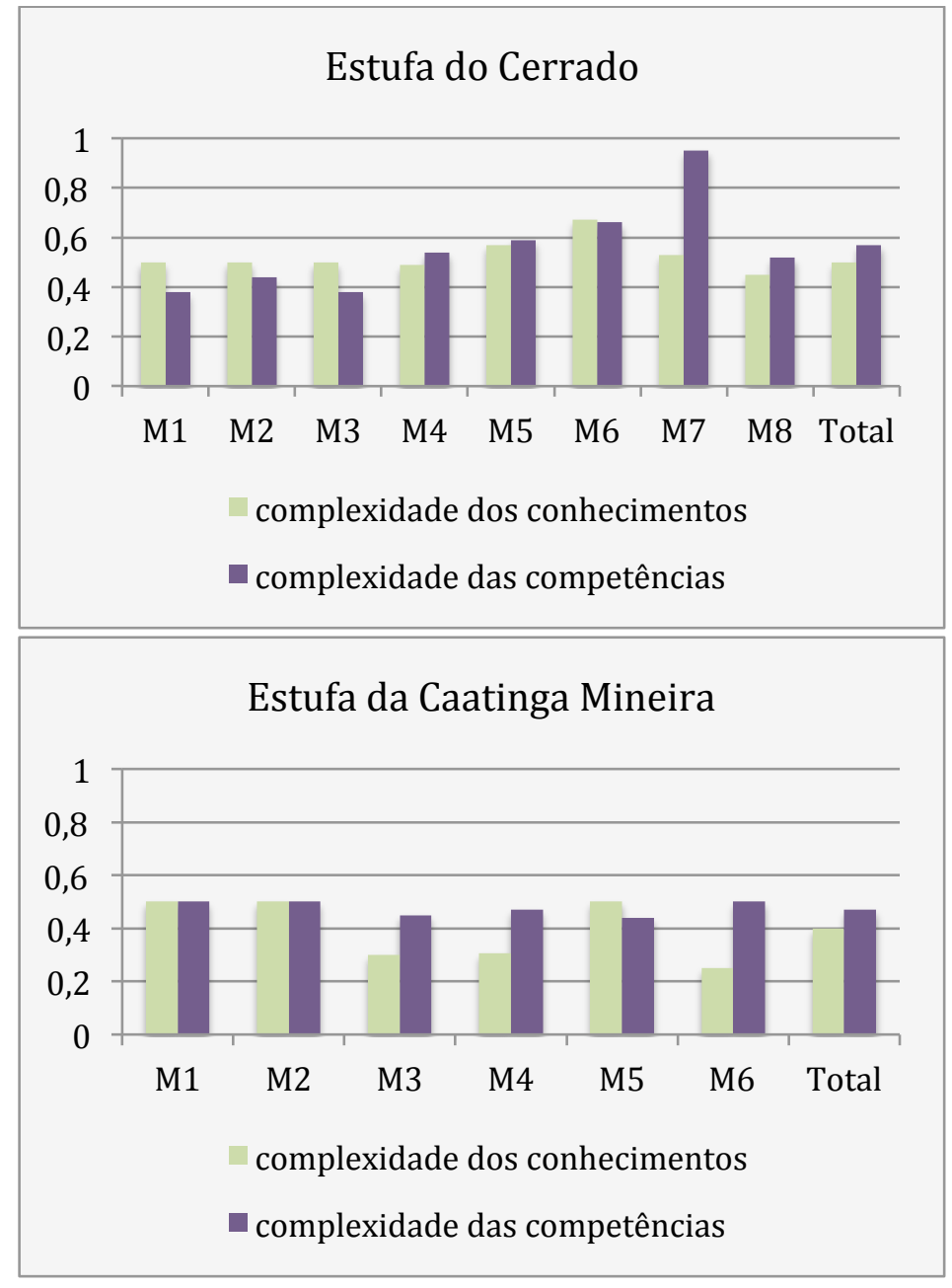

Figura 4.17: Índice de complexidade dos conhecimentos e competências. Valores dos índices de complexidade dos conhecimentos científicos e das competências cognitivas calculados por módulo e total - "Estufa do Cerrado" e "Estufa da Caatinga Mineira", respectivamente.

Os diagramas de dispersão das frequências de cada grau de complexidade dos conhecimentos e competências por módulo é apresentado na figura 4.18. 0 diagrama da "Estufa do Cerrado" mostra existência de um relacionamento entre as variáveis analisadas. Isto significa que o aumento da complexidade dos conhecimentos está associado ao aumento da complexidade das competências. Essa tendência não ocorre no diagrama da "Estufa da Caatinga Mineira". 

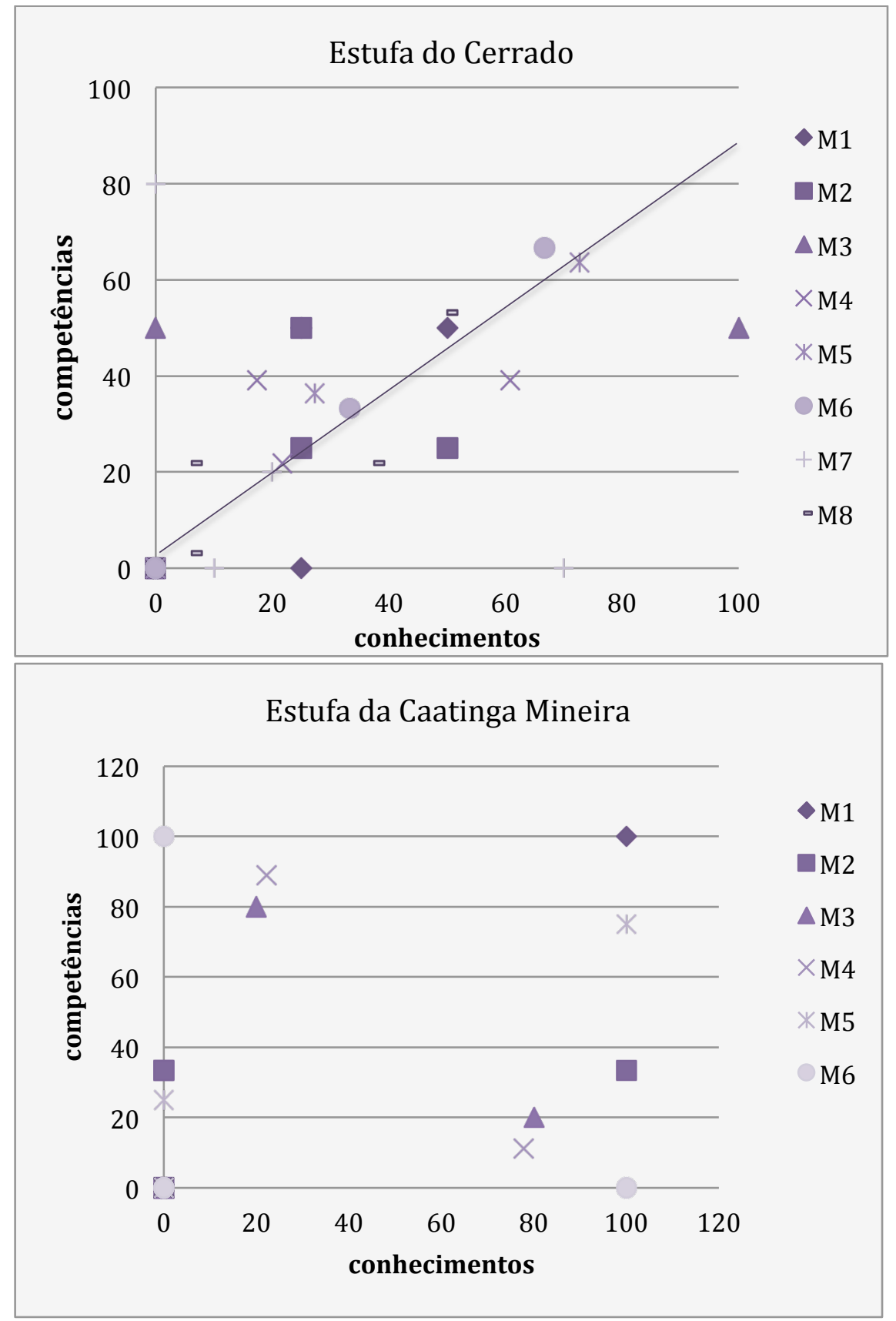

Figura 4.18: Diagramas de dispersão das frequências de cada grau de complexidade dos conhecimentos e competências por módulo, nas estufas do Cerrado e da Caatinga Mineira.

\subsubsection{As relações entre discursos relacionados à biodiversidade - "o como" do discurso}

Foram analisadas 93 unidades presentes na exposição "Estufa do Cerrado" e 24 unidades na "Estufa da Caatinga Mineira" quanto ao "como" do discurso em três diferentes indicadores: relações entre os conhecimentos de diferentes disciplinas/áreas (interdisciplinaridade), entre os componentes do 
termo biológico de biodiversidade e entre seres humanos e natureza (abordagens de biodiversidade).

Da mesma forma como a análise do "que" do discurso, cada unidade de análise foi categorizada de acordo com o grau de estabelecimento das relações, utilizando o conceito de classificação, para cada um dos indicadores acima explicitados. Assim, as relações podem variar de classificações fortes até classificações muito fracas, conforme descrito no capítulo 2. Após a categorização, foi calculada a frequência de cada grau de relacionamento no conjunto das unidades (total) e por módulo. Os resultados relacionados às frequências para cada um dos indicadores do "como" do discurso são apresentados nos itens: Relação entre saberes e conhecimentos de diferentes áreas; Relações entre os componentes do termo biológico de biodiversidade $e$ Relações entre natureza e humanos - abordagens sociais do termo biodiversidade.

As unidades de análise também foram utilizadas para a análise das relações entre os módulos, cujos resultados são apresentados no item a seguir.

Relação entre os conteúdos dos módulos

Como foi explicitado no capítulo 2, realizamos em um nível mais abrangente, a análise das relações entre os módulos no que diz respeito aos conteúdos abordados. Nas unidades de análise de cada módulo buscamos identificar a presença dos conteúdos principais dos demais módulos. As tabelas 4.1 e 4.2 apresentam nos títulos os subtemas de cada módulo e os principais conteúdos tratados neles.

A figura 4.19 mostram unidades de análise dos módulos as relações estabelecidas entre os módulos das exposições, quanto aos conteúdos. 

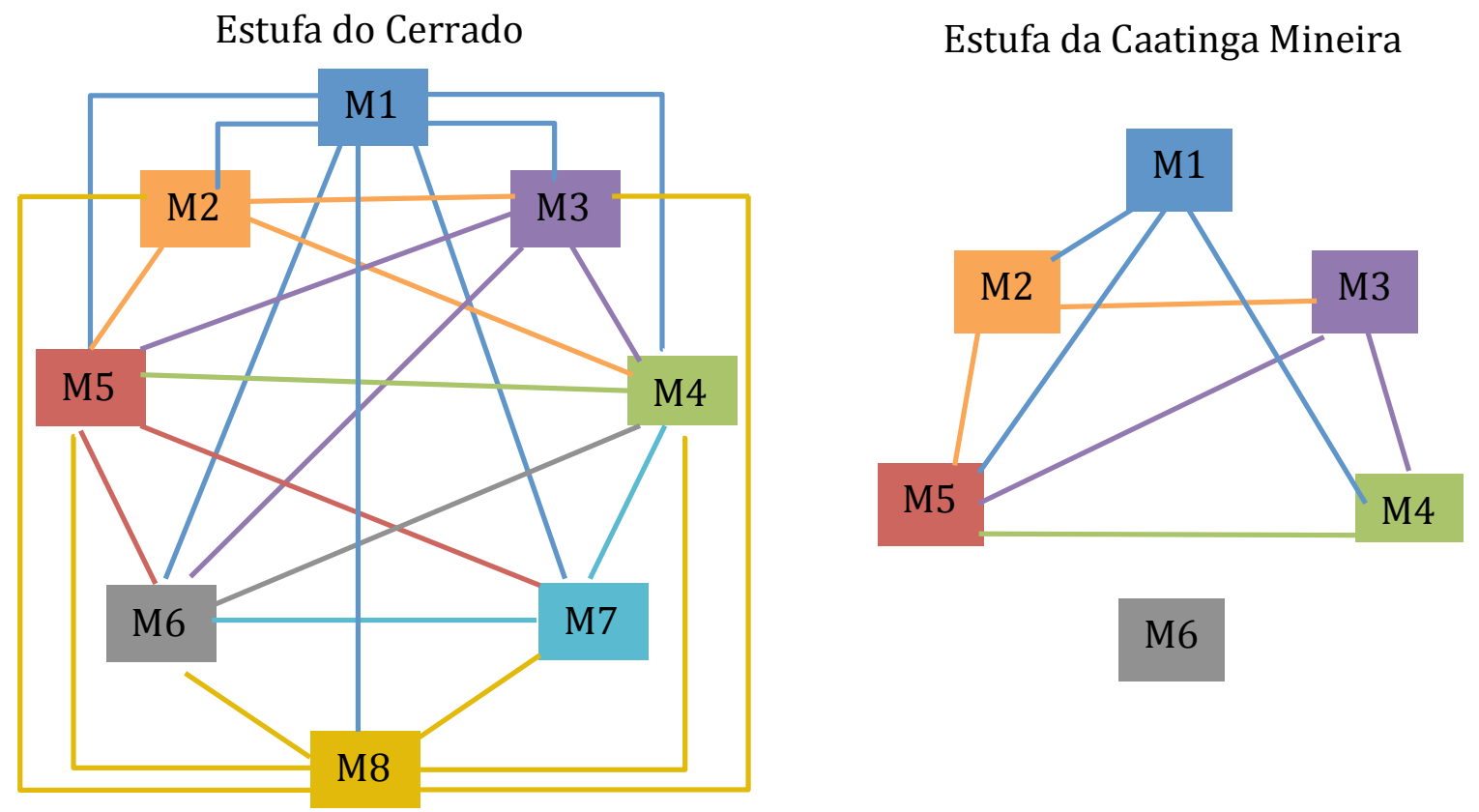

\section{M6}

Figura 4.19: Diagramas mostrando as relações entre os módulos, estabelecidas por meio da presença de conteúdos das subtemáticas de um módulo nos demais módulos, nas exposições "Estufa do Cerrado" e "Estufa da Caatinga Mineira".

Com base na análise dos conteúdos, nota-se pelo diagrama que na exposição sobre o Cerrado todos os módulos, em maior ou menor grau, apresentam relações com outros. Especificamente os módulos 1, 4, 5 e 8 estabelecem relações com todos os outros, ou seja, os conteúdos principais de cada um desses módulos são anunciadas ou retomadas em todos os demais. $\mathrm{Na}$ figura 4.14, apresentada anteriormente, podemos notar que a unidade de análise, presente no módulo 7, retoma aspectos sobre fogo, solo e fisionomias que são os conteúdos principais dos módulos 5, 6 e 4, respectivamente. Já a figura 4.20 mostra uma unidade de análise do módulo 2, em que são anunciados os conteúdos centrais dos módulos 4 e 5. 


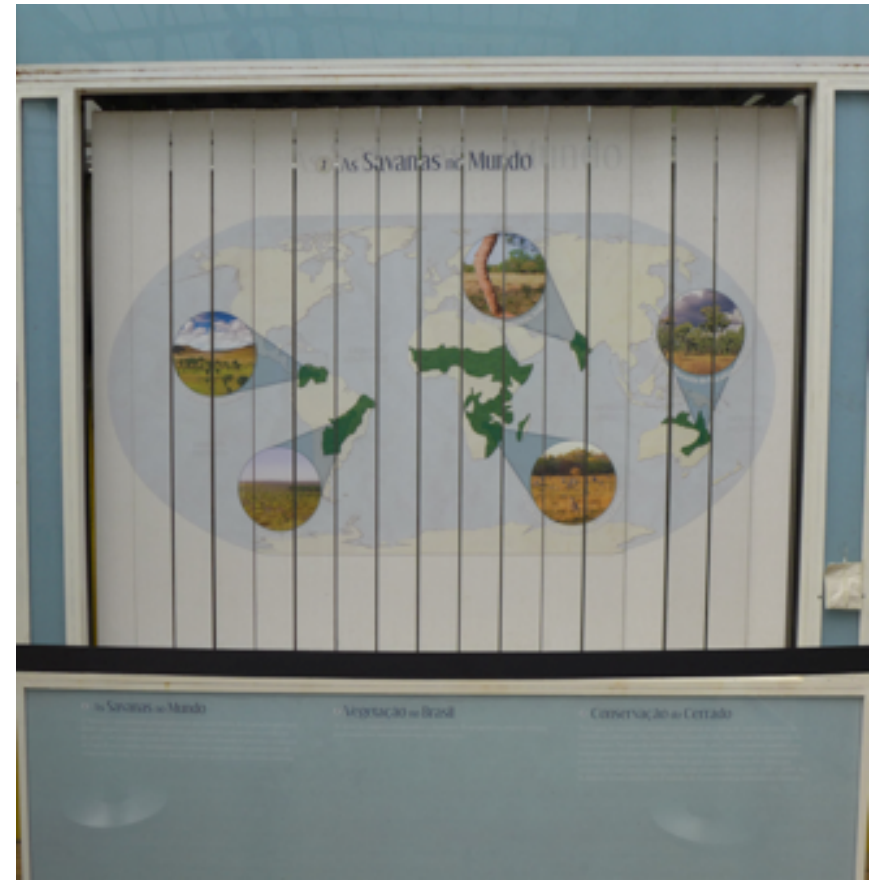

Figura 4.20: "Estufa do Cerrado", unidade 5, módulo2.

Transcrição do texto do painel: "A Savana é caracterizada principalmente por uma forma de vegetação que varia desde campos - compostos principalmente por gramíneas adaptadas a condições de seca - até arvoredos, com árvores e arbustos tolerantes à presença ocasional de fogo."

$\mathrm{Na}$ "Estufa da Caatinga Mineira” os conteúdos presentes nos módulos estão menos inter-relacionados. Destacamos que de acordo com os resultados, os conteúdos centrais tratados no módulo 6, sobre ameaças ao bioma e estratégias de conservação, não ocorre em nenhum outro módulo. No outro extremo, o módulo 5 é o único em que os conteúdos apresentam relações com todos os demais módulos, exceto o 6. As figuras 4.6, apresentada anteriormente, e a figura 4.21, a seguir, exemplificam unidades de análise do módulo 5, nas quais é possível observar a relação com os conteúdos principais dos módulos 2 (clima) e 4 (flora e adaptações). 

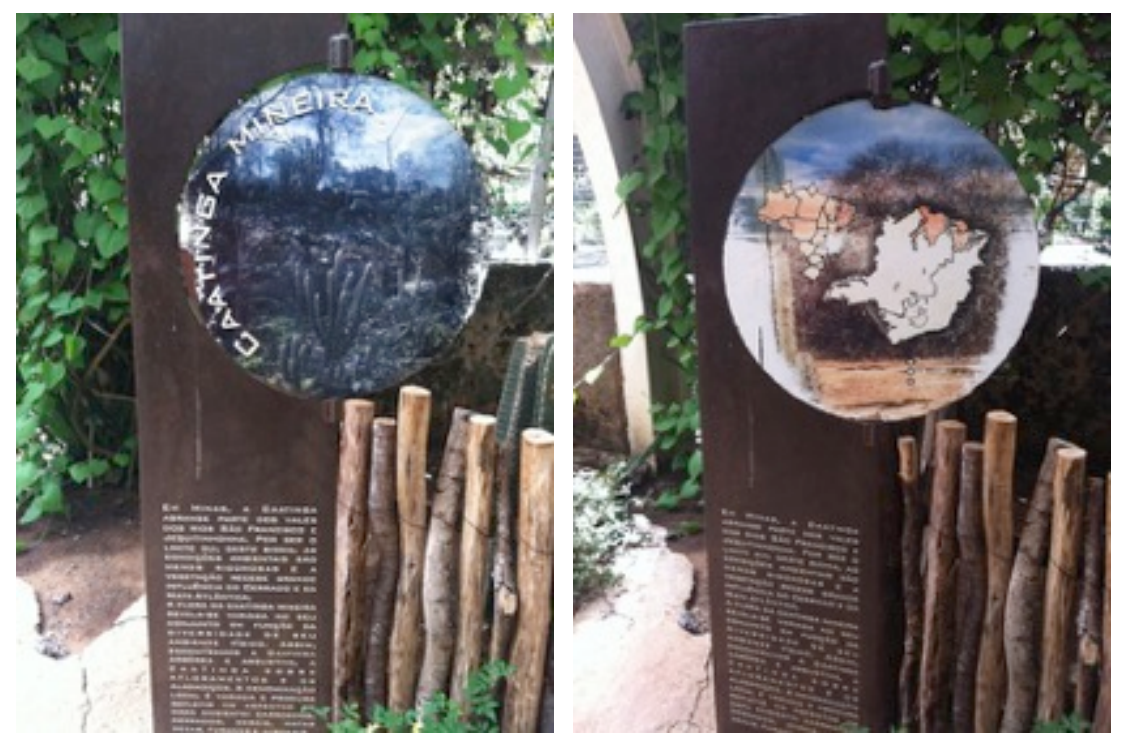

Figura 4.21: "Estufa da Caatinga Mineira”, unidade 1, módulo5.

Transcrição do texto do painel: "Em Minas, a caatinga abrange parte dos vales dos rios São Francisco e Jequitinhonha. Por ser o limite sul deste bioma, as condições ambientais são menos rigorosas e a vegetação recebe grande influência do cerrado e da mata atlântica."

Relação entre saberes e conhecimentos de diferentes áreas (interdisciplinaridade)

$\mathrm{Na}$ análise da interdisciplinaridade foram consideradas os graus de relação entre os diversos saberes e/ou conhecimentos de diferentes áreas, expressos nas unidades de análise. As relações podem variar de classificações fortes até classificações muito fracas, conforme descrito no capítulo 2, quadro 2.3.

Após a categorização, foi calculada a frequência de cada grau de relacionamento no conjunto das unidades (total) e por módulo. Os resultados são apresentados na figura 4.22 .
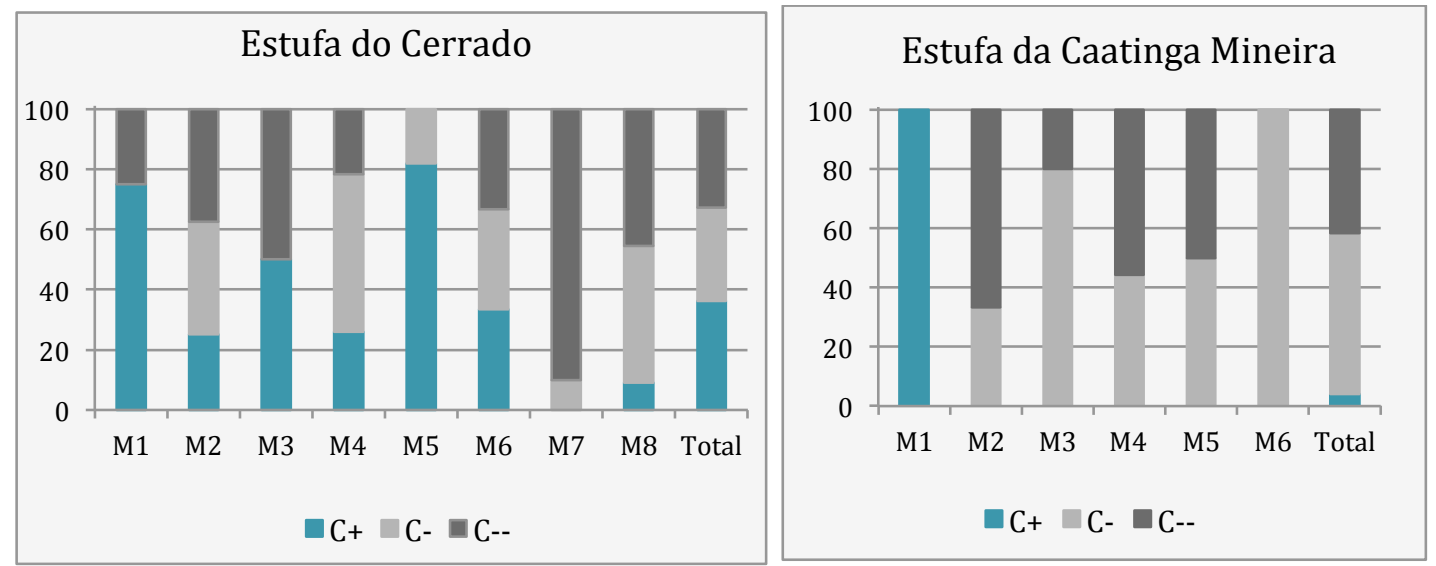

Figura 4.22: Grau de relação entre os conhecimentos de diferentes disciplinas ou áreas, por módulo e total. 
Considerando o conjunto das unidades de análise da exposição "Estufa do Cerrado", nota-se que há uma distribuição bastante similar entre as classificações. As relações fracas (C-) representam 34\% do total das unidades, os outros dois graus, classificações fortes $(\mathrm{C}+)$ e muito fracas (C--) estão presentes em 33\% das unidades cada uma. Isso mostra que há um equilíbrio entre os graus de classificação no total de unidades analisadas. Contudo, esse equilíbrio não ocorre na análise por módulo. Nesse caso, há módulos em que predomina um dos graus de classificação. A figura 4.23 apresenta um exemplo de classificação fraca (C-).
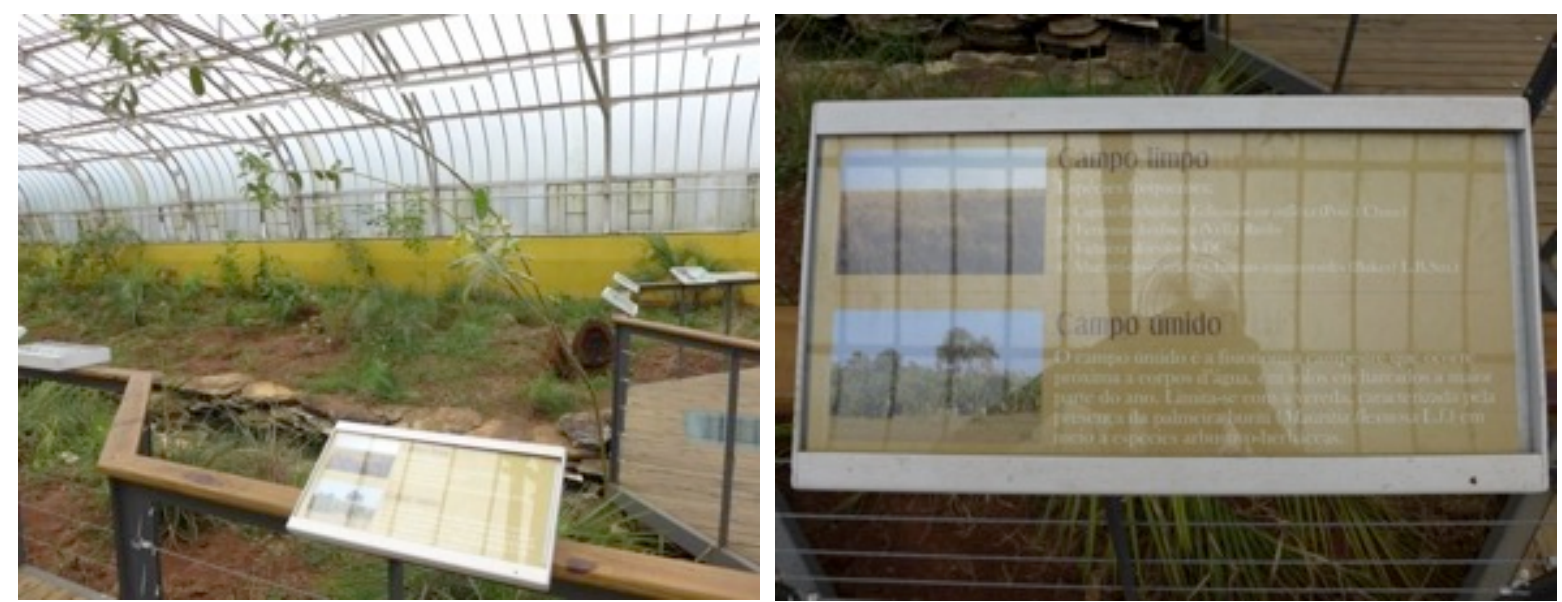

Figura 4.23: "Estufa do Cerrado", unidade 11, módulo 4.

Transcricão do texto:

"Campo limpo

Espécies frequentes:

1) Capim-flechinha (Echinolaena inflexa (poir) Chase)

2) Vernonia herbácea (Vell.) Rusby

3) Viguiera discolor A. DC.

4) Abacaxi-do-Cerrado (Ananas ananassoides (Baker) L.B. Sm.)"

- Interdisciplinaridade: classificação fraca (C-), relaciona biologia (espécies botânicas) com expografia em que as espécies vivas estão numeradas de acordo com a placa.

Já na exposição sobre a Caatinga Mineira, a análise do conjunto das unidades mostra que as classificações fracas (C-) são predominantes, representando 54\% do total de unidades. A classificação muito fraca representa 41\% e apenas 5\% das unidades são de classificação forte. Assim como na outra exposição não há um padrão de distribuição das classificações nos módulos, porém há apenas um deles (M1) que possui unidades de classificação forte. A figura 4.24 apresenta um exemplo de classificação muito fraca (C--). 


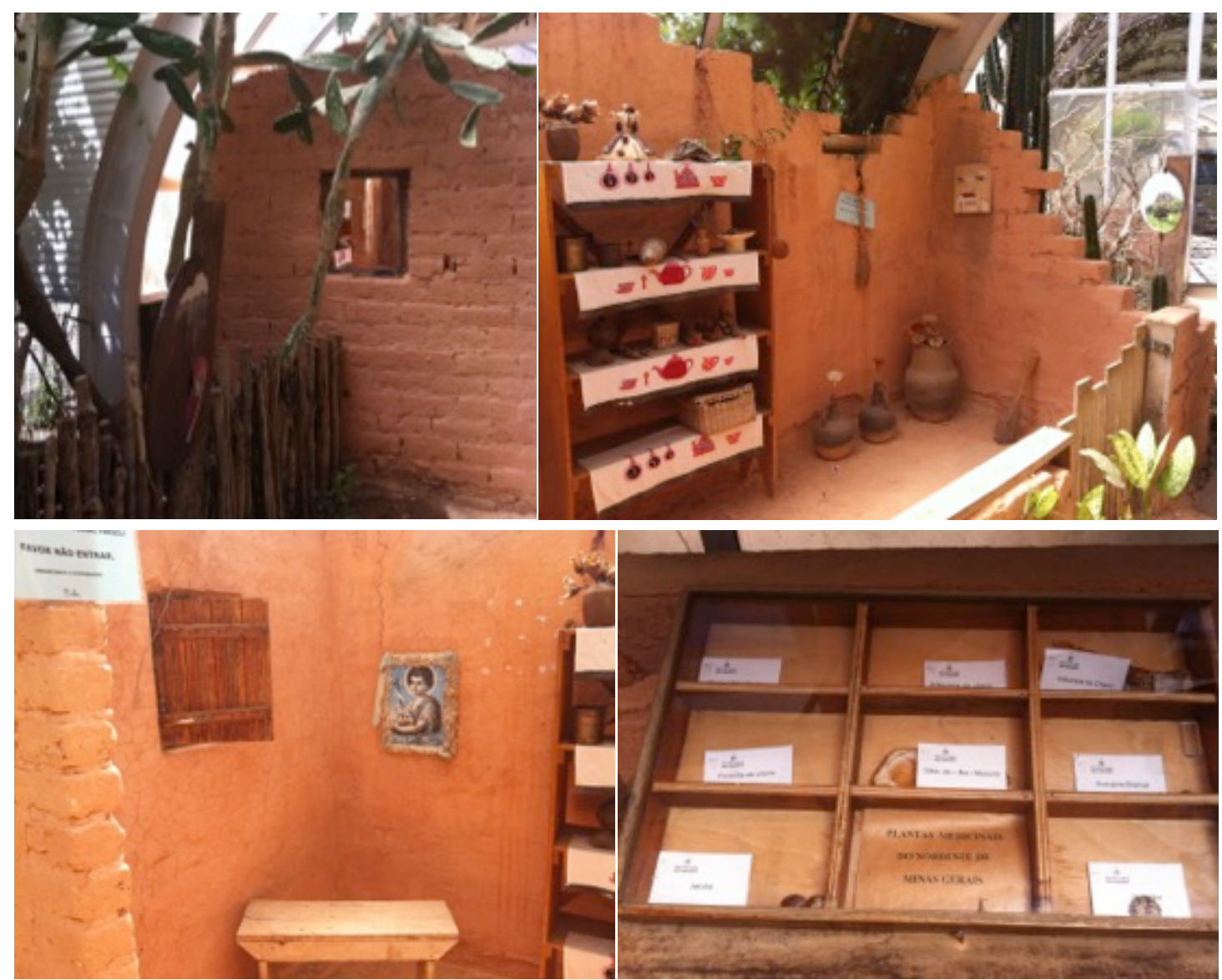

Figura 4.24: "Estufa da Caatinga Mineira”, unidade 5, módulo 3.

Transcricão do texto: "A cultura é uma das grandes riquezas das regiões onde ocorre a Caatinga Mineira. É integrada com a natureza e tem íntima relação com as atividades econômicas, especialmente a agricultura e a pecuária. Com origem nas antigas comunidades indígenas e africanas locais, essa cultura manifesta-se de diversas formas, como exemplos podemos citar: culinária, música, uso de plantas medicinais, religiosidade e vestimentas."

- Interdisciplinaridade: classificação muito fraca (C--) relaciona biologia (botânica), expografia, saberes tradicionais etc.

Relações entre os componentes do termo biológico de biodiversidade (mais fraca a classificação mais complexo)

Os resultados apresentados neste item dizem respeito aos graus de relação entre os componentes da biodiversidade. As relações podem variar de classificações fortes até classificações muito fracas, conforme descrito no capítulo 2, quadro 2.4 .

A frequência dos graus de relação entre os componentes da biodiversidade, considerando o total das unidades de análise e por módulo em cada exposição, é mostrada na figura 4.25. 


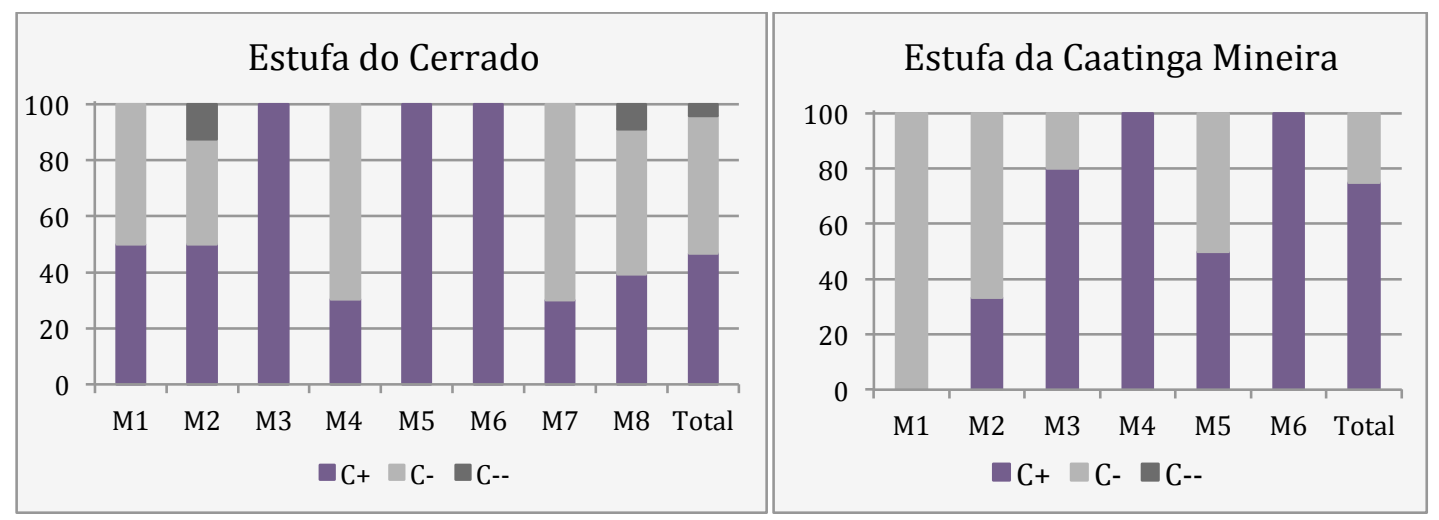

Figura 4.25 : Grau de relação entre os componentes da biodiversidade, conforme definição do termo nas ciências biológicas, por módulo e total.

Considerando o conjunto das unidades de análise da exposição "Estufa do Cerrado" nota-se que há um predomínio de classificações fracas (49\%), em seguida estão as classificações fortes $(46,8 \%)$ e em pequena porcentagem as classificações muito fracas $(4,2 \%)$. Isso mostra que a maior parte das unidades de análise envolve dois dos componentes da biodiversidade.

No que se refere à distribuição dos graus de classificação nos módulos, notamos que não há um padrão, alguns módulos possuem unidades com todos os tipos de classificação e outros em que há apenas classificações fortes. Alguns módulos, como o M2 e M8, apresentam maior equilíbrio entre unidades com menor e maior grau de relações entre os componentes.

A "Estufa do Caatinga" apresenta predomínio de classificações fortes (75\%) no total das unidades de análise. As classificações fracas representam $25 \%$ das unidades. Não foram categorizadas unidades de análise com relações muito fracas.

Da mesma forma que ocorre na exposição sobre o Cerrado, a distribuição dos graus de classificação nos módulos não segue um padrão na "Estufa da Caatinga Mineira". Alguns módulos possuem apenas classificações fortes ou fracas, e outros apresentam os dois graus de classificação.

Com base no total de unidades de análise, foi calculada a frequência dos componentes da biodiversidade, quando ocorrem individualmente; das relações entre dois deles (classificações fracas) e das relações entre todos eles (classificações muito fracas). A figura 4.26 mostra tais porcentagens calculadas 
para as unidades de análise da "Estufa do Cerrado" e da "Estufa da Caatinga Mineira", respectivamente.
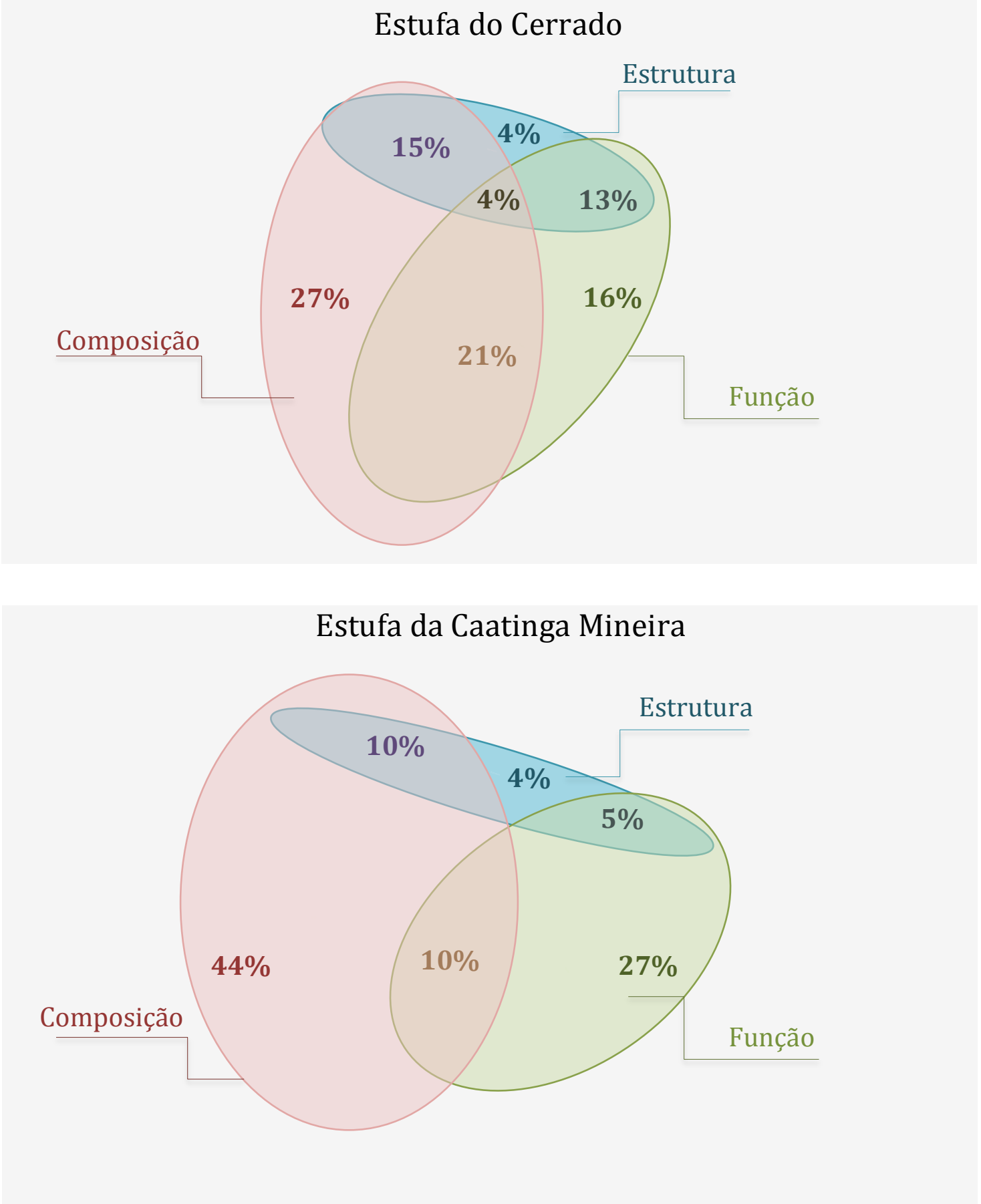

Figura 4.26: Diagramas de Venn mostrando a frequência dos diferentes componentes da biodiversidade e das relações entre eles nas exposições "Estufa do Cerrado" e "Estufa da Caatinga Mineira".

Nas duas exposições, dentre as unidades de classificação forte, em que ocorre apenas um dos componentes, os elementos composicionais são os mais 
frequentes, seguidos pela função e estrutura, nessa ordem. Já nas unidades de classificação fraca, na "Estufa do Cerrado" são mais frequentes as relações entre composição e função. Nessa exposição, as outras relações desse grau (estrutura e função; composição e estrutura) apresentam frequência bastante similar. $\mathrm{Na}$ "Estufa da Caatinga Mineira" as relações entre composição e função e entre composição e estrutura apresentam a mesma frequência. Já as relações entre estrutura e função são menos frequentes. A figura 4.27 exemplifica uma unidade de classificação forte $(\mathrm{C}+$ ), presente na "Estufa do Cerrado". A figura 4.28 mostra um exemplo de unidade de classificação fraca (C-) na "Estufa da Caatinga Mineira".

De maneira geral, considerando as ocorrências individuais e as interações entre os componentes, a diversidade composicional é a mais presente nas exposições, seguida pela funcional e estrutural. Ressaltamos ainda que em ambas exposições é frequente a associação dos componentes da biodiversidade ou das relações entre eles com fatores abióticos, no espaço e/ou no tempo.

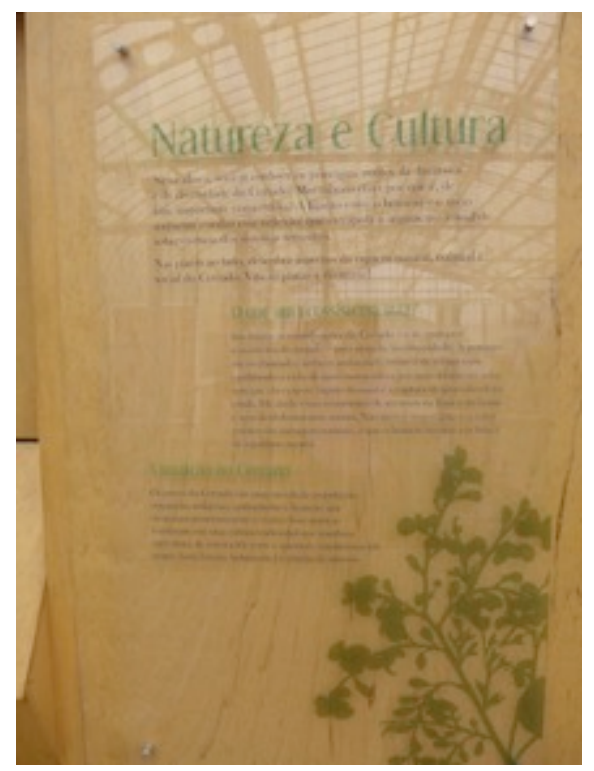

Figura 4.27: "Estufa do Cerrado", unidade 1, módulo 8.

Transcrição do texto na painel: "Os povos do Cerrado são uma mescla de populações originárias indígenas, quilombolas e brancas, que ocuparam posteriormente a região. Suas práticas resultaram em uma cultura tradicional que combina agricultura de coivara (de corte e queima), extrativismo (de pequi, baru, faveira, babaçu etc.) e criação de animais."

- Relações entre componentes da biodiversidade: classificação forte (C+), composição. 




Figura 4.28: "Estufa da Caatinga”, unidade 4, módulo5.

Transcrição do texto na painel: "As paisagens do relevo cárstico do norte de Minas Gerais, vale do rio São Francisco, destacam-se no cenário nacional. A porosidade das rochas e as fendas permitem a ocorrência de espécies de porte fabuloso, como os embarés. A predominância é dos cactos colunares ou globosos e das bromélias de folhas muito rígidas. Os afloramentos se apresentam como lajes lisas e extensas ou como rochas pontiagudas. Onde há uma circulação subterrânea de água, a flora é adaptada ao ritmo de secas e inundações. Destacam-se aí os imbiraçus, mulungus e grande quantidade de ervas."

- Relações entre componentes da biodiversidade: classificação fraca (C-), relaciona composição, estrutura da paisagem, espaço e fatores abióticos.

\section{Relações entre natureza e humanos - abordagens sociais do termo biodiversidade}

Neste item apresentamos os resultados da análise do "como" do discurso quanto às relações entre "natureza e humanos". As relações podem variar de classificações fortes até classificações muito fracas, conforme descrito no capítulo 2, quadro 2.5 .

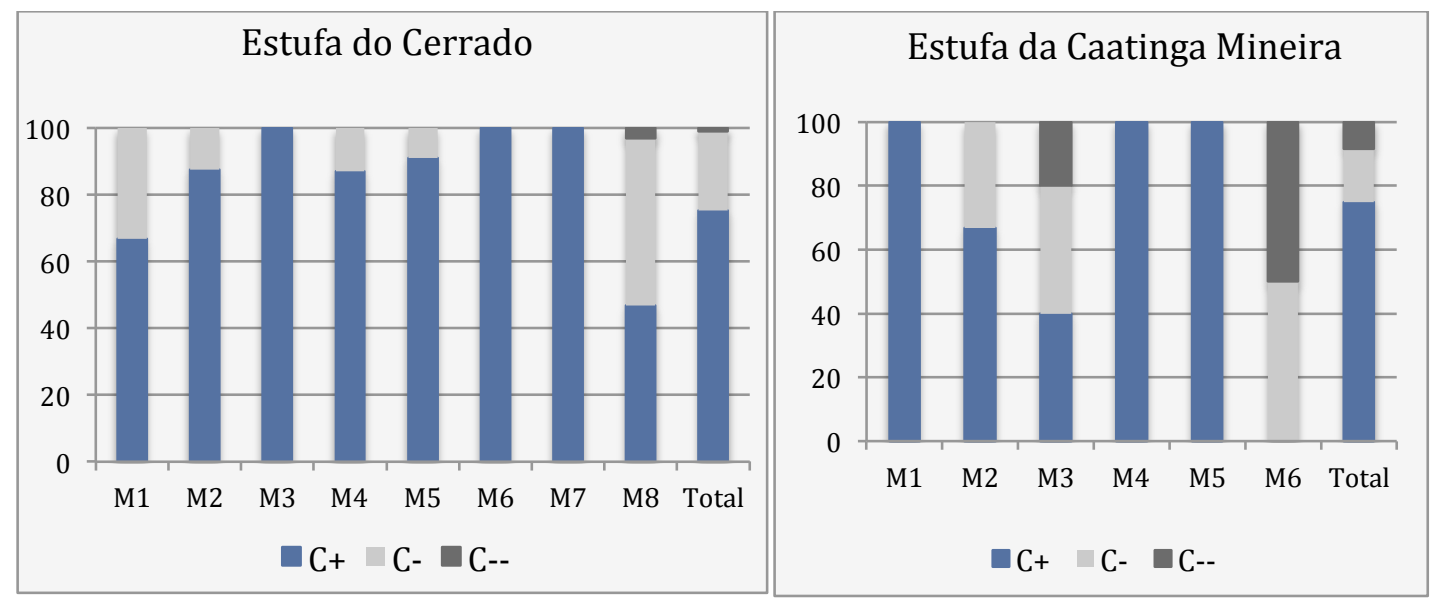

Figura 4.29: Grau de relação entre o ser humano e a natureza - representações sociais da biodiversidade, por módulo e total. 
Levando em consideração o total das unidades de análise, há um predomínio da classificação forte (C+) em ambas as exposições (Fig. 4.29). Esse tipo de classificação, em que o ser humano está a parte da biodiversidade, representa 77,5\% e 75\% das unidades de análise na exposição sobre o Cerrado e sobre a Caatinga Mineira, respectivamente.

As relações fracamente classificadas (C-) ocorrem em aproximadamente 21,5\% das unidades de análise, dentre elas, metade das relações são de oposição entre humanos e natureza e a outra metade inclui os benefícios da natureza para o ser humano e natureza. Na "Estufa do Cerrado", apenas 1\% das unidades apresentam classificação muito fraca (C--), em que as relações complexas e multidimensionais entre homem e natureza. Na "Estufa da Caatinga Mineira" as classificações fracas (C-) correspondem a 16,5\% e as muito fracas (C--) a 8,5\% das unidades de análise. Dentre as relações fracamente classificadas (C-), os benefícios da natureza para o ser humano estão presentes em 75\% das unidades e as relações de oposição entre humanos e natureza em $25 \%$.

A análise por módulo, mostra que em cerca de um terço dos módulos da "Estufa do Cerrado" e metade dos módulos da "Estufa da Caatinga Mineira" há apenas classificações fortes.

As figuras 4.30 e 4.31 trazem exemplos de unidades de classificação fraca (C-) e forte (C+), presentes na exposição sobre o Cerrado e a Caatinga Mineira, respectivamente.
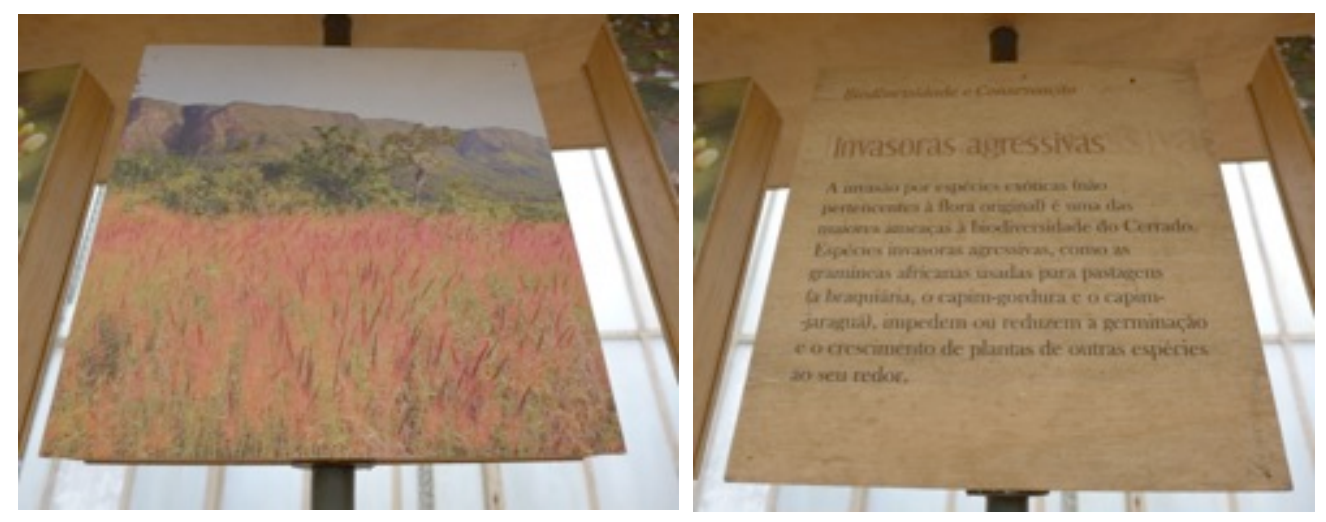

Figura 4.30: "Estufa do Cerrado", unidade 27, módulo 8.

Transcrição do texto do painel: "Biodiversidade e conservação. A invasão por espécies exóticas (não pertencentes à flora original) é uma das maiores ameaças à biodiversidade do Cerrado. Espécies invasoras agressivas, como as gramíneas africanas usadas para pastagens (a braquiária, o capim-gordura e o capim-jaraguá), impedem ou reduzem a germinação e o crescimento de plantas de outras espécies ao seu redor."

- Relações natureza e humanos: classificação fraca (C-), há relação de oposição entre natureza e humanos. 


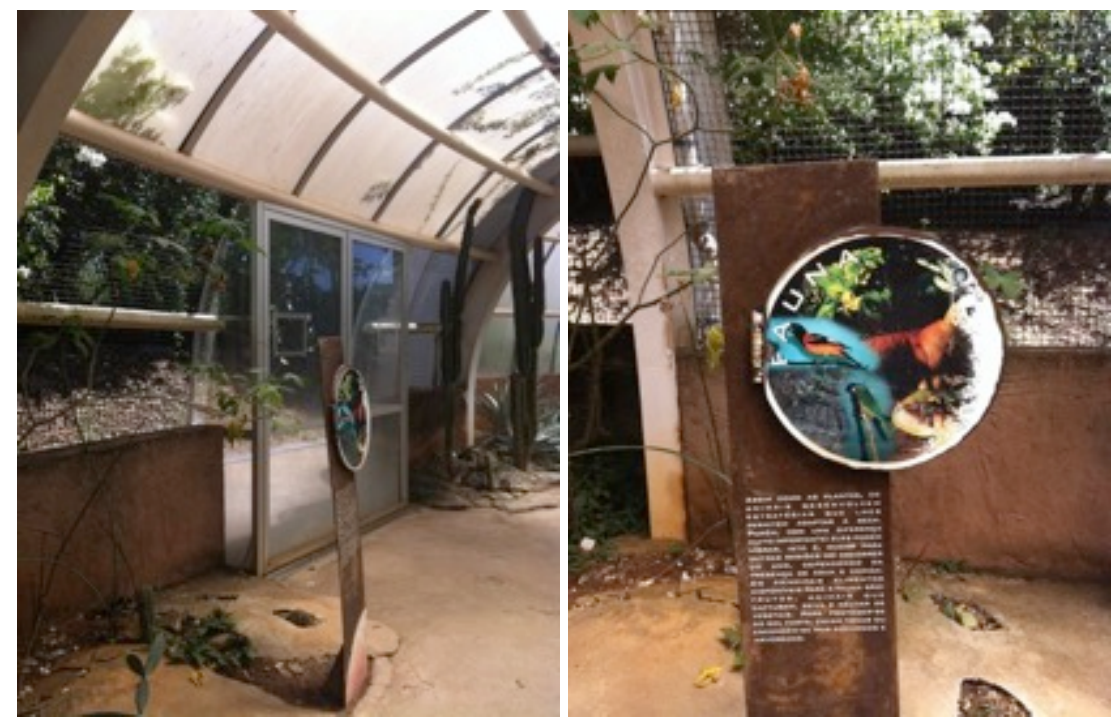

Figura 4.31: "Estufa da Caatinga mineira”, unidade 2, módulo 4.

Transcrição do texto do painel: "Assim como as plantas, os animais desenvolvem estratégias que lhes permitem adaptar à seca. Porém, com uma diferença muito importante: eles podem migrar, isto é, mudar para outras regiões no decorrer do ano, dependendo da presença de água e comida."

- Relações natureza e humanos: classificação forte $(C+)$, não é estabelecida relação entre humanos e natureza.

\subsubsection{O nível de exigência dos conteúdos}

Conforme explicitado no item sobre o tratamento dos dados - capítulo 2, calculamos o índice de complexidade utilizando as frequências de unidades de análise, categorizadas nos diferentes graus e classificações. Esse cálculo foi aplicado sobre os resultados de cada um dos indicadores (complexidade dos conhecimentos, complexidade das competências, interdisciplinaridade, intradisciplinaridade e relações humanos e natureza) no conjunto das unidades de análise - índices totais.

Vale lembrar que o índice varia de 0 até 1 , sendo que valores mais altos correspondem a níveis mais elevados de "complexidade" que compõem discurso expositivo.

Os índices de cada instrumento, nas exposições estudadas são apresentados na figura 4.32. Os resultados permitem verificar quais indicadores contribuem mais para o nível de exigência dos conteúdos sobre biodiversidade em cada uma das exposições. 


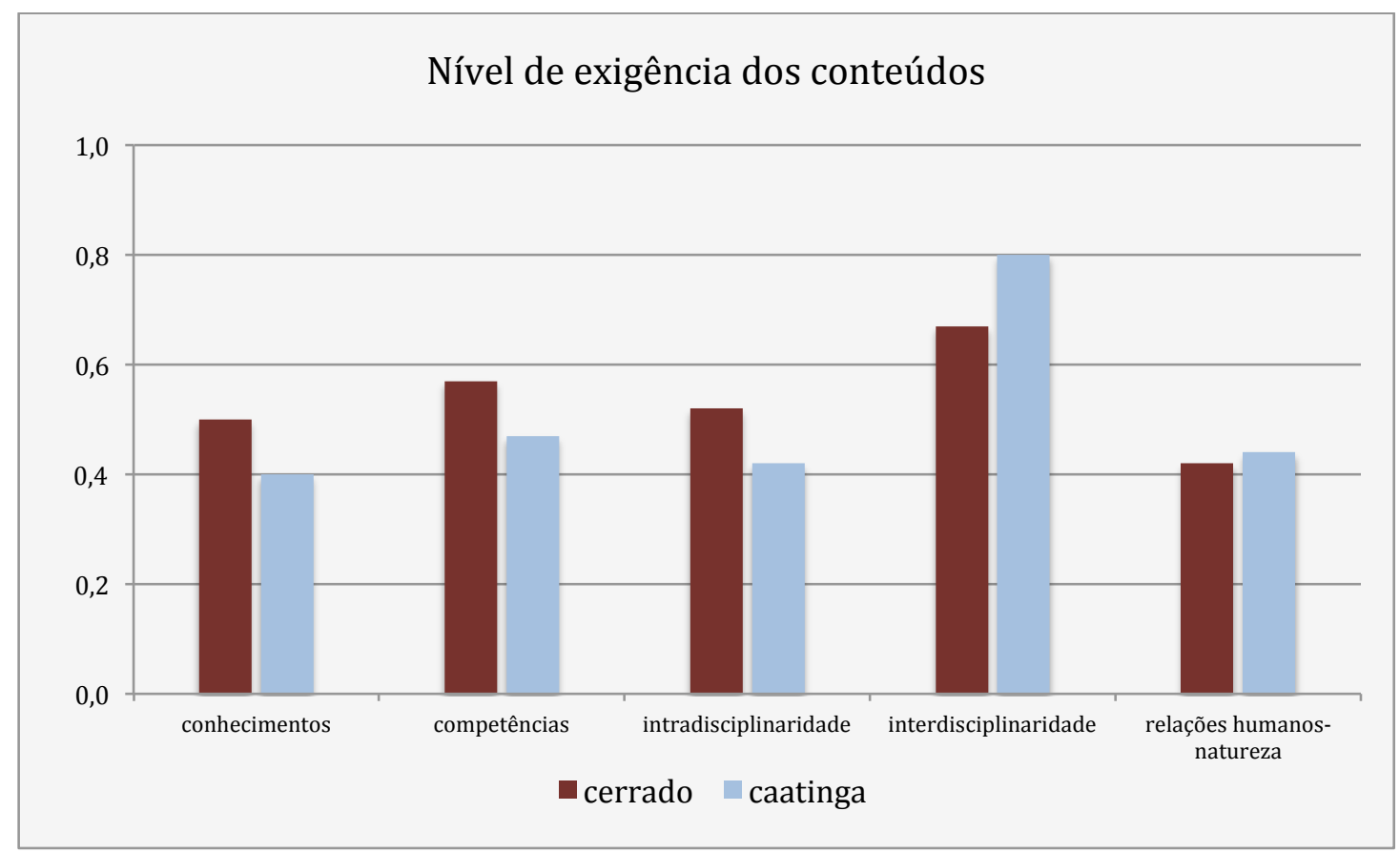

Figura 4.32: Índices totais de cada indicador: complexidade dos conhecimentos, complexidade das competências, relações interdisciplinares, relações intradisciplinares; relações humanos e natureza.

Os resultados mostram que em ambas exposições a interdisciplinaridade apresenta valor mais elevado de exigência dos conteúdos. Na "Estufa do Cerrado", o menor valor refere-se às relações homem natureza e na "Estufa da Caatinga Mineira" são os conhecimentos que apresentam valores mais baixos.

Nota-se assim que a interdisciplinaridade, ou seja, as relações entre os diferentes saberes e/ou diferentes áreas do conhecimento, contribui para o aumento da complexidade da mensagem sobre biodiversidade tratada nas exposições.

\subsection{Discussão}

\subsubsection{Complexidade dos conhecimentos e competências relacionados à biodiversidade - o "que" do discurso}

Conforme os índices e a distribuição dos graus de complexidade dos conhecimentos (figuras 4.7 e 4.17) as exposições apresentam conhecimentos mais concretos com baixo nível de abstração, tais como fatos relacionados e conceitos simples. Da mesma forma, guardadas as devidas proporções, a maior parte das unidades de análise mostram que as potenciais competências a serem 
mobilizadas são aquelas de ordem mais simples, como a memorização e a compreensão das informações.

Analisando o processo de recontextualização no contexto da educação formal, Galian (2011) mostrou que há uma significativa redução dos níveis de complexidade dos conhecimentos entre as mensagens presentes no discurso pedagógico oficial, discurso pedagógico presente no livro didático e ainda, entre os dois primeiros e as práticas de sala de aula. A autora sugere que a maior presença de conhecimentos simples no material e, especialmente, na prática de aula, dificulta a integração dos conhecimentos em torno de temas mais abrangentes, como é o caso da biodiversidade. 0 mesmo ocorre em relação às competências, chamando a atenção para a baixa possibilidade de acesso dos alunos aos temas unificadores e teorias, que abarcam diferentes níveis de complexidade dos conceitos e competências.

Diversos trabalhos do grupo de Estudos Sociológicos de Sala de Aula (ESSA) têm analisado a complexidade dos conhecimentos científicos e capacidades cognitivas. Considerando que a educação em ciências reflete a estrutura hierárquica do conhecimento, que integra conhecimentos em níveis crescentes de abstração (BERNSTEIN, 1999), esses trabalhos apontam para a importância de que a educação em ciências leve à compreensão de conceitos e ideias amplas, incluindo também capacidades complexas que vão além da compreensão de conceitos e teorias, mas que permitam utilizá-los (ALVES e MORAIS, 2012; CALADO e NEVES, 2012; CALADO, NEVES e MORAIS, 2013; MORAIS, NEVES e FERREIRA, 2014; SILVA, MORAIS e NEVES, 2013).

Nas entrevistas, os conceptores de conteúdos científicos das exposições afirmam que os conhecimentos tratados na exposição são bastante simples e, intencionalmente, foram desenvolvidos pensando no contexto expositivo e na heterogeneidade do público ao qual se destinam.

Eu acho que ali a gente abordou conceitos bem... é bem... que delimitam o ambiente, que delimitam as adaptações que as plantas têm, e as plantas que têm lá. A gente foi no que é importante para a pessoa entender a caatinga. Agora, assim, as coisas mais elaboradas não. (...)

Não, os que a gente colocou lá (conceitos), eu acho que a gente conseguiu explicar bem; assim, eu não acho que é tão abstrato assim não. (CAA2) 
(...) é muito difícil essa tradução. E traduzir de uma forma compreensível pra todo mundo. Eu acho que um professor tem muito mais facilidade do que alguém que está sempre em um laboratório escrevendo artigo científico, que vai ser lido pelos seus pares. Eu já escrevi algumas coisas de divulgação, mas é complicado, não é muito fácil não. A gente diminuir a quantidade de informação e usar as palavras certas porque é outro tipo de comunicação né? (CER1)

Disso, decorrem duas considerações, a primeira delas diz respeito ao processo de produção das exposições, conforme apontaremos à frente. A segunda consideração tem relação com as distâncias e aproximações possíveis entre os contextos formais e não formais de educação, com destaque às especificidades das exposições.

O contexto das exposições é único e revela-se pela ênfase, em maior ou menor escala, aos objetos, dando-lhes significados de acordo com ideias e intenções (DEAN, 1994; DAVALLON, 2005). Além do papel ímpar dos objetos, as exposições possuem ainda as especificidades do espaço e do tempo. Para Davallon (op. cit.), no processo de concepção das exposições, o espaço tem um papel preponderante que antecede ou acaba por dar outros sentidos ao discurso.

As exposições estudadas possuem ainda uma especificidade relacionada à forma de conceber esses espaços. Elas apresentam a reprodução de ambientes naturais de forma mais realística possível, conjuntamente com elementos característicos de exposições como painéis com textos e imagens, objetos e aparatos interativos. Esse tipo de museologia chamada "imersiva" traz uma nova forma de relação entre visitante e exposição (BALAËN, 2003). Para Davallon (2010), esse tipo de exposição contextualiza o objeto na medida em que recria um contexto de origem e ao mesmo tempo, determina ao visitante um ponto de vista, levando-o a imergir no universo que lhe foi apresentado.

Entendemos que essas especificidades das exposições contribuíram para a complexidade das competências cognitivas terem sido maiores que a dos conhecimentos científicos (figura 4.17). A representação do ambiente natural associado aos diferentes tipos de objetos e estratégias expositivas, como vídeo e aparatos interativos, permitem a mobilização de competências diversas, para além daquelas que podem ser mobilizadas apenas por meio dos textos e imagens. 
Vale lembrar que as unidades de análise consideram tanto os textos escritos quanto imagens, objetos e outros aparatos associados.

Analisando a figura 4.8 notamos que os módulos que possuem as maiores porcentagens de unidades de análise de grau 3 e 4 de complexidade das competências, são justamente aqueles em que há uma maior diversidade de estratégias expositivas.

0 módulo 2 da "Estufa da Caatinga Mineira" por exemplo, traz uma representação natural da vegetação do bioma na época seca, destacando a cor cinza e homogênea do estrato herbáceo e arbustivo em um ambiente tridimensional imersivo. Inseridas nesse ambiente, placas tratam de diferentes aspectos sobre a vegetação e o clima da caatinga. Uma interessante estratégia nesse módulo é a presença de uma placa giratória (figura 4.15) com imagens da mesma paisagem na época seca e chuvosa. O conjunto formado pelo texto, imagens e ambiente natural permitem que o visitante compare a vegetação da Caatinga em diferentes estações do ano, distinga modificações na paisagem e conclua que elas estão relacionadas à maior ou menor presença das chuvas. As exposições se valem de algumas estratégias como as do exemplo, além de infográficos e modelos tridimensionais que favorecem a comparação, especialmente entre as fisionomias e paisagens, tendo sido esta a ação mais frequente dentre as competências de grau 3.

Ainda a título de exemplo, o módulo 7 da exposição "Estufa do Cerrado", que apresenta o maior nível de complexidade das competências, possui um aparato interativo (figura 4.14) no qual o visitante pode levantar critérios e testar hipóteses sobre a relação entre a periodicidade do fogo e o tipo de solo do Cerrado para a formação de determinadas fisionomias.

As competências mais presentes nas exposições analisadas são aquelas de grau 2, que envolvem a compreensão do conhecimento. Ao observarmos a figura 4.12 notamos que entre as principais competências presentes nas exposições, estão a descrição complexa ("Estufa do Cerrado") e a ilustração ("Estufa da Caatinga Mineira").

A descrição complexa, segundo Marzano e Kendall (2008), envolve a integração do conteúdo e a identificação da estrutura básica da informação. As unidades de análise que apresentaram essa competência são aquelas em que o 
papel do texto é bastante importante, trazendo descrições que incluem informações sobre os elementos-chave de fenômenos ou como determinados fatos e características estão relacionados. Já a ação de ilustrar refere-se à representação simbólica da informação (MARZANO e KENDALL, 2008). Nas unidades de análise que propiciam esse tipo de habilidade, destacam-se em geral, o papel das imagens ou da representação do ambiente natural (figura 4.15). Segundo Martins e colaboradoras (2005), as imagens no ensino de ciências conduzem aos processos de construção de representações, por meio de descrições ou analogias.

De acordo com Dean (1996), as exposições com maior apelo à informação do que orientadas pelos objetos, possuem grande quantidade de texto, voltadas à transmissão da mensagem. No que se refere à complexidade dos conhecimentos, notamos, nas exposições analisadas, um papel preponderante dos textos na explicitação de conceitos, fenômenos ou fatos.

A presença de textos, assim como de elementos didatizantes, é uma característica bastante marcante da exposição "Estufa do Cerrado". Vale pontuar que a quantidade de textos nessa exposição é duas vezes maior por área que na "Estufa da Caatinga Mineira"44. Os conceptores de conteúdo e expografia dessa última exposição afirmaram nas entrevistas, que houve unanimidade quanto à menor quantidade de textos no espaço expositivo, tendo em vista que os visitantes poderiam ter acesso aos conteúdos de forma mais aprofundada em terminais multimídia, disponíveis para o público em um edifício contíguo à exposição ${ }^{45}$.

Então, assim, a gente colocou as informações essenciais, eu diria, até um pouco mais, em termo do texto inicial, e tal; mas, o vínculo com o quiosque era certo: quem quer saber de mais coisa, busca lá. (CAA5)

\footnotetext{
${ }^{44}$ A quantidade de texto nas exposições foi calculada pela relação entre o número de palavras dos textos dos painéis e legendas e área expositiva em metros quadrados.

45 Os terminais multimídia não estavam em funcionamento durante o período de coleta de dados. Apesar de terem sido pensados durante a concepção da exposição, os recursos financeiros para tais dispositivos e espaço, não estavam previstos no projeto aprovado para o desenvolvimento da exposição.
} 
(...) é aquilo que eu já disse, de você conseguir extrair daquele conjunto de informações que você tem, de extrair mui... falar muito bem dele em poucas frases. Então, isso aí é o que... porque você não pode colocar textos enormes; e eles ainda são grandes, pela nossa avaliação. Pelo o que a gente sabe, que as pessoas não leem. (CAA2)

Um exemplo interessante da utilização de elementos didatizantes na "Estufa do Cerrado" pode ser observado no painel que apresenta um infográfico associado ao texto e imagens (figura 4.13). Além de permitir que o visitante identifique e compare características das diferentes fisionomias, possibilita a compreensão do conceito de fisionomia e a relação dele com outras características das paisagens do Cerrado. Há ainda um outro aspecto interessante em relação ao painel com o infográfico e textos, pois de acordo com todos os conceptores entrevistados, a disposição da vegetação foi planejada para que o público pudesse perceber as gradações das fisionomias do Cerrado, das formas de vegetação mais abertas para as mais fechadas. Todavia, esse objetivo não pôde ser plenamente concretizado em uma escala pequena como a da exposição. Nesse caso, o painel com textos e infográfico, propicia ao visitante a apreensão dessa estrutura do ambiente natural, e ao mesmo tempo, favorece a distinção de elementos das diferentes fisionomias que foram apresentadas nos textos e infográficos.

Um elemento didatizante comum nos textos da "Estufa do Cerrado" é a definição, utilizado para explicar palavras e conceitos. Em geral, nas unidades de grau 3, os textos apresentam definições de conceitos e a eles associam-se fatos ou características. 0 uso de elementos didatizantes é característico dos textos de divulgação científica e também estão presentes em textos de exposições (MARANDINO, 2002).

Em ambas exposições é possível notar uma tendência à apresentação dos conteúdos desde um ponto de vista da história natural. Tratam-se de textos descritivos, com detalhes e relações entre as características dos ambientes e espécies. Essas são justamente as características definidoras mais presentes nas exposições: fatos relacionados ("Estufa do Cerrado") e exemplos e fatos ("Estufa da Caatinga Mineira"). 
Dentre os exemplos (características definidoras de grau 1), é possível notar que ambas exposições trazem, por meio de imagens e texto, informações sobre organismos característicos dos biomas representados. Geralmente os textos são breves e apresentam os nomes populares e/ou científicos das espécies. A tendência em apresentar aspectos da riqueza dos biomas, em especial exemplificar as espécies que vivem em determinado ambiente, está presente também no trabalho de Bueno (2016). A autora constatou que a intenção principal do diorama da Floresta Amazônica, presente no Museu de Zoologia da USP, é apresentar para o público exemplos dos organismos que compõem a biodiversidade do bioma, além dos elementos que o caracterizam.

Como assinalado anteriormente, estão envolvidos no processo de recontextualização que levou ao discurso expositivo analisado neste trabalho, as intenções e os objetivos dos conceptores. Da mesma forma, constituem outros aspectos que precisam ser considerados nesse processo a posição dos indivíduos nas equipes, a relações entre eles e as instituições que abrigam as exposições, as formas de financiamento, entre outros.

Nesse sentido, convém destacar que tais aspectos do processo de recontextualização dos discursos em cada exposição, apresentam características bastante diversas, que nos permitem inferir sobre as diferenças apresentadas entre os índices de complexidade dos conhecimentos e competências, além da distribuição deles ao longo dos módulos.

A "Estufa da Caatinga Mineira" foi concebida por meio de um edital internacional e desde a fase da submissão do projeto, estiveram envolvidos praticamente todos os membros da equipe que atuou até o final do processo. No edital havia diretrizes que fizeram com que a equipe tivesse uma atuação junto à comunidade das regiões de Caatinga mineira. Esse aspecto teve grande influência na valorização da cultura local na exposição, ocorrendo em várias unidades de análise um maior apelo aos aspectos poéticos que visam esclarecer os objetos dessa cultura ou da relação dos seres humanos com a natureza. De acordo com Roque (2010), essas características estão presentes nos discursos em que a comunicação é mais centrada no público, envolvendo-o afetivamente com o conteúdo da mensagem. Aspectos de uma narrativa mais sensitiva estão presentes nessa exposição, acarretando em menor ênfase à informação e com 
isso, menor complexidade dos conhecimentos científicos e competências cognitivas.

Por outro lado, o conceito inicial que levou ao desenvolvimento da "Estufa do Cerrado" envolveu, a princípio, poucos pesquisadores. Foram esses que conseguiram apoio da instituição para a captação do financiamento junto ao órgão estadual de meio ambiente. Uma característica essencial no processo de concepção da "Estufa do Cerrado" é que as relações de poder e controle eram desiguais, centradas nas mãos desses pesquisadores, muito influentes na área de ecologia e botânica do Cerrado. Isso pode explicar a centralidade dessa exposição em relação à informação, bem como a maior complexidade dos conhecimentos.

As exposições diferem ainda quanto a presença de um relacionamento entre as variáveis analisadas - complexidade dos conhecimentos e das competências (figura 4.18). Na "Estufa do Cerrado" esta relação pode ser observada. 0 resultado tem relação com a ênfase da exposição nas informações científicas e portanto, com a de divulgação e apropriação de conceitos por nãoespecialistas e, em última análise, com a própria natureza dos saberes científicos.

De acordo com Van-Praet e colaboradores (2005), por conta do caráter abstrato dos conceitos e teorias, as exposições científicas precisam recorrer a artefatos, imagens, esquemas e desenhos para materializá-los e permitir sua interpretação pelo público. Além disso, destaca o autor, os textos são restritos nesse espaços, precisam ser breves tanto para permitir o tipo de leitura específica, como também para que eles não ocupem espaço. 0 conhecimento científico, em especial o de cunho mais biológico, é assim, visual e metalinguístico. Os resultados da análise da exposição sobre o Cerrado, uma vez mais centrada na informação científica, mostram que os textos junto aos objetos, aparatos e imagens formam um conjunto de significados que segundo Davallon (2010), visam facilitar a interpretação do outro. Assim, mobilizam conhecimentos e competências mais abstratas de forma mais integrada.

A integração dos conhecimentos em torno de temas mais abrangentes e portanto, de maior complexidade, aparecem como intenção por parte dos conceptores de conteúdo científico da exposição “Estufa do Cerrado”. A ideia era apresentar ao público aspectos acerca do clima, solo, fogo e vegetação e como eles interagem para formar as paisagens do Cerrado. A sequencia definida é tal 
que ao final do percurso, esperava-se que o público pudesse integrar esses aspectos, no sentido de atingir o objetivo, expresso pelos conceptores de conteúdo, que é fazer com que o público conheça o bioma para então entender a sua importância. 0 aumento do nível de complexidade ao longo da exposição reforça essa tendência (módulos 5, 6 e $7^{46}$ ).

Na "Estufa da Caatinga Mineira” a intenção dos conceptores de conteúdo da exposição foi mostrar as paisagens da Caatinga Mineira e a diversidade de culturas presentes na região. Ainda que os aspectos acerca do clima, solo e vegetação sejam apresentados, a sequência expositiva não tem como foco a integração dos vários elementos naturais que formam o bioma. 0 elemento integrador é justamente "essas diversidades" e os módulos possuem um maior grau de independência entre si. Nesse caso, a complexidade varia de forma heterogênea ao longo da exposição.

Assim como há diferenças, há algumas similaridades nos processos de desenvolvimento de ambas as exposições. Uma das aproximações desse processo é que, conforme afirmaram os conceptores de conteúdos, não foram utilizados documentos oficiais curriculares e de educação em museus, tampouco, materiais de referência das áreas de museologia e expografia. Essa característica mostra que dentre os conhecimentos nos quais não são especialistas ou para os quais não têm uma formação específica, os conceptores de conteúdo deram ênfase às suas experiências práticas. A valorização das experiências fica nítida quando na entrevista, um dos conceptores de conteúdo (CER3) da "Estufa do Cerrado" afirma que a exposição tem como base a aula de campo destinada ao ensino superior, deferida por um dos pesquisadores. As experiências práticas com exposições foram também a base para o desenvolvimento do projeto expográfico da "Estufa da Caatinga Mineira", realizado por um pesquisador em botânica.

\footnotetext{
${ }^{46} 0$ módulo 8, último da exposição, não tem essa característica, trata-se de um módulo bastante diverso dos demais, que traz muitos exemplos específicos de fauna, flora, conservação e cultura do Cerrado, que não tem relação entre si. Nesse caso, a intenção era dar exemplos da diversidade do Cerrado. Inclusive, esse módulo foi concebido apenas ao final da fase de projeto para incluir aspectos como conservação e cultura, temas que de acordo com um dos conceptores, teriam maior espaço em versões iniciais do anteprojeto.
} 


\subsubsection{As relações entre discursos relacionados à biodiversidade - "o como" do discurso}

Diversos saberes e conhecimentos estão presentes em exposições com temáticas científicas. De acordo com Marandino (2001), para além do discurso científico, podem estar presentes os discursos educacional, museológico, expográfico, da divulgação e comunicação da ciência, além das áreas técnicas como iluminação, carpintaria, eletrônica etc. As exposições analisadas dão ênfase a uma temática específica, e em torno dela, apresentam uma narrativa que pode integrar, em maior ou em menor escala, saberes diversos e conhecimentos de diferentes áreas. Essa interdisciplinaridade, considerando as características das exposições analisadas, está a priori presente, tanto por terem "biomas" como temática principal, quanto pela expografia que integra objetos, textos e outros aparatos de acordo com uma narrativa. No entanto, como apontam os resultados apresentados na figura 4.22, os saberes e conhecimentos de diferentes áreas nas exposições analisadas podem estar mais ou menos integrados.

O predomínio de classificações mais fracas (fracas e muito fracas) vai de encontro com a ideia acima apresentada. De forma geral, saberes diversos e conhecimentos de diferentes áreas estão articulados nas exposições analisadas, contribuindo para uma abordagem mais complexa da biodiversidade.

Dentre as unidades de análise de grau elevado de classificação $(\mathrm{C}+)$, notamos que em muitos casos, elas não possuem objetos, imagens ou aparatos associados ao texto, ou essa associação é meramente ilustrativa, não contribuindo assim para a compreensão da informação. Os textos que compõem essas unidades também não apresentam relação entre diferentes áreas do conhecimento científico ou educacional, abordando, na maioria dos casos, apenas os conhecimentos biológicos. Essas características estão presentes, principalmente, nos módulos 1 da "Estufa da Caatinga Mineira" e "Estufa do Cerrado".

Em alguns módulos há unidades de análise em que texto e imagem estão desconectadas fisicamente. Esse é o caso do vídeo sobre o fogo no Cerrado (módulo 5), em que o texto que explica o fenômeno está em um painel na face perpendicular ao aparato. Ainda que tenhamos analisado esses elementos em 
conjunto, vale ressaltar que a expografia, que em geral contribui para a integração de outros saberes e conhecimentos, pode também dificultar essa articulação. Vale destacar que para Gomez e Ariza (2012), os aparatos didáticos de interação com o visitante pressupõem uma plataforma de transmissão. Nesse sentido, a tipologia dos aparatos, materiais, formas, posição, iluminação limitam as opções do discurso educacional. Recursos textuais e imagens, por exemplo, têm que se adaptar às características físicas dos aparatos. Há assim, segundo os autores, uma relação entre expografia e discurso educacional, demonstrando a importância de envolver na concepção da exposições especialistas em educação.

As relações entre discursos de diferentes áreas e disciplinas científicas nessa exposição são pressupostos do próprio tema. De acordo com as entrevistas junto aos conceptores de conteúdo da "Estufa do Cerrado", esse bioma é formado por um conjunto de aspectos de diferentes áreas e de como eles interagem. Para os conceptores era essencial que a exposição abordasse os temas fogo, solo, clima e fatores bióticos, e como eles se relacionam formando paisagens diferentes, mas que, no conjunto, possuem uma unidade. Assim, o discurso científico é composto por vozes de outras áreas do conhecimento, como a geologia, geografia, climatologia, entre outras.

E aí houve uma preocupação em se mostrar quais os fatores ambientais determinantes do Cerrado como um bioma. Então existe uma estrutura que mostra a precipitação, a distribuição da precipitação ao longo do ano, que existe uma época de chuva, que existe uma época de seca.. Isso é importante na determinação do bioma. Existe o fogo, as várias fisionomias, desde campo limpo até o cerradão. 0 solo, como é o solo de uma mata, como é o solo do Cerrado, como é o solo do campo. Então houve uma preocupação de trazer essas informações, no sentido de mostrar que o bioma é determinado por esses fatores em conjunto. 0 Cerrado não existe porque existe. (CAA2)

A proposta de apresentar o bioma como um conjunto de aspectos interrelacionados, expressa pelos conceptores de conteúdo da exposição sobre o Cerrado, está contemplada na análise das relações entre os módulos (figura 4.19). Nessa exposição, cada subtema é abordado para além do módulo em que é central, em diferentes outros momentos, conferindo um caráter integrador na forma de apresentação dos conhecimentos sobre o bioma. Os resultados 
apontam também para uma narrativa de gênero comum ao discurso cientifico, na qual há uma introdução mais geral e que apresenta os aspectos que serão tratados a seguir, o aprofundamento dos diferentes aspectos e fechamento. Os resultados das relações entre os conteúdos dos módulos 1 e 8 refletem esse modelo. Além deles, o módulo 4 também apesenta conteúdos de todos os demais módulos. É justamente nesse conjunto expositivo que são apresentadas as fisionomias do bioma, por meio de diversas estratégias, entre elas a representação do ambiente natural. Esse subtema refere-se às paisagens, formadas pela integração entre os diversos fatores que compõem o bioma.

A temática com forte presença dos fatores bióticos, relacionados portanto, ao discurso científico da biologia, explica o destaque dessa área e sua maior hierarquia nas unidades de análise da exposição "Estufa do Cerrado". Ao aprofundarmos a análise das relações entre as áreas e disciplinas, notamos que dentre os conhecimentos biológicos, há ênfase nas áreas da botânica e ecologia. Conforme as entrevistas e observações, essas áreas são evidenciadas por conta de três questões fundamentais. A primeira delas refere-se aos agentes do processo de recontextualização envolvidos na concepção da exposição desde o conceito inicial. Tratam-se de pesquisadores de referência das áreas de botânica e ecologia do Cerrado, situados portanto, no campo do controle simbólico e responsáveis pelo projeto junto à instituição que abriga a exposição.

A segunda questão relevante para o maior estatuto dessas áreas, em especial da botânica, diz respeito a instituição que a abriga ser um instituto de pesquisa em botânica. De acordo com os entrevistados, a exposição está dentro de um jardim botânico e foi realizada sob a chancela do Instituto de Botânica e Secretaria de Estado do Meio Ambiente de São Paulo. Essas questões, para além de explicar a ênfase em determinados conhecimentos, é essencial para a compreensão das escolhas que foram feitas e das outras relações que foram estabelecidas, uma vez que esses agentes tiveram maior poder de decisão ao longo do processo de concepção da exposição sobre o Cerrado. De acordo com Silva e Loureiro (2013), as narrativas expositivas que têm origem no conhecimento científico, como aquelas presentes em museus de história natural, espelham as áreas de investigação dos conceptores, dando legitimidade às informações. Os autores afirmam ainda que o discurso expositivo permite 
revelar as relações de poder subjacentes à estrutura institucional, na medida em que as instituições autorizam quais informações podem ser disponibilizadas e, portanto, quais delas constituem ou não os conhecimentos válidos.

Em terceiro lugar, há ainda a questão relacionada à expografia de imersão, baseada nas fisionomias do Cerrado. Nessa exposição, a reprodução do ambiente natural é feita com base na apresentação das fisionomias do bioma, caracterizadas pela variação na densidade, altura e composição da vegetação. Os elementos de fauna aparecem em pequeno número, apenas em alguns pontos da reprodução do ambiente natural. Essa representação simula a experiência que um visitante teria na natureza, onde primeiro são percebidos aspectos relacionados às formas de vegetação e à inserção delas na paisagem, além de aspectos abióticos, como a camada superficial do solo e os cursos d'água, para apenas num segundo momento, com um olhar mais atento, serem percebidos elementos ligados à fauna.-Nesse caso, assim como em outros biomas brasileiros, os elementos da fauna não são, na maioria das vezes, de fácil visualização. Normalmente a presença de animais é feita de forma indireta, por meio de indícios como os sons, cheiros e vestígios. Na "Estufa do Cerrado" há outros elementos de fauna destacados em pequenas vitrines e janelas de piso.

A análise da exposição sobre a Caatinga mostra também que o próprio tema propicia a relação de discursos científicos de diferentes áreas do conhecimento. Da mesma forma como na exposição sobre o Cerrado, há uma maior presença do discurso da botânica por conta da relação institucional e pelo financiamento da exposição ter sido realizado por meio do "Prêmio Projetos Educacionais Modelos nos Jardins Botânicos brasileiros", concedido pelo "Projeto Investindo na Natureza - Brasil", sob a chancela do órgão internacional de jardins botânicos - Botanic Gardens Conservation International (BGCI).

Sobre a presença dos saberes e áreas de conhecimento na exposição sobre a Caatinga, chama atenção a importância dada às questões culturais. As entrevistas mostram que a equipe de concepção tinha a intenção de valorizar o bioma, tanto do ponto de vista da sua flora, fauna e interações, quanto enfatizar a diversidade cultural abrangendo a íntima relação entre o sertanejo e o ambiente em que vive. Conforme CAA2: 
Por ser um bioma tipicamente brasileiro, a gente queria valorizar esse tipo de coisa aqui; e por ele ser em Minas, estar como limite sul dele; então, ele, por isso mesmo, tem as suas especificidades por conta dos contatos com Cerrado, com Mata Atlântica. Não é área core da caatinga, é o limite sul; e que... e também por isso, a gente sabia que ela estava indo para o brejo.

Bom, a ideia da exposição, de ter esses elementos culturais, era uma... era um desejo assim que foi surgindo nas conversas, coisas... com a equipe, por conta também da gente ter esse... essa interface com a população local; então, isso levou com que a gente também explorasse essa riqueza cultural deles, o jeito de viver; e tentar-se, de uma certa forma, trazer isso para a cidade, para as pessoas conhecerem; e para... como se fosse também uma homenagem, entre aspas, a esse modo de vida deles, que é tão particular.

Assim, na "Estufa da Caatinga Mineira", os aspectos culturais estão fortemente presentes na exposição, representados por exemplo, na reprodução de uma moradia típica (com mobiliário característico) e uma barraca de feira de plantas medicinais (figura 4.24), além de objetos de artesanato da região. 0 discurso expositivo agrega, assim, outras áreas de conhecimento, como a antropologia e ciências sociais, além dos saberes tradicionais sobre uso medicinal de plantas e técnicas de construção, trazendo à cena outros discursos e outras possibilidades de relações. Vale destacar que na "Estufa da Caatinga Mineira", o módulo sobre o sertanejo ocupa quase um terço da exposição. Na "Estufa do Cerrado" os aspectos culturais aparecem apenas no final da exposição e, segunda a entrevista com um membro equipe de expografia, forma reduzidos ${ }^{47}$ a alguns dos elementos giratórios do painel principal do módulo 8.

Como foi dito acima, outra área importante neste jogo de relações é a expografia. Esta área pode ser considerada um discurso, em que a sua presença pode estar mais ou menos isolada das outras áreas (MARANDINO, 2014). No caso desta exposição, esse discurso assume papel essencial a partir da ideia de imersão que, de acordo com os conceptores de ambas exposições, era a forma desejada para tratar dos biomas. A ideia era que o visitante pudesse conhecê-los por meio de uma vivência, relacionada tanto às experiências de atividades de

\footnotetext{
${ }^{47}$ De acordo com a entrevista realizada com a equipe de expografia, o projeto inicial realizado por eles, incluia uma grande área sobre os povos do Cerrado, incluindo objetos típicos da cultura local.
} 
campo dos conceptores, como das novas abordagens expositivas em museus. Além disso, os conceptores foram unânimes quanto a maior possibilidade de aprendizagem que esse tipo de exposição pode proporcionar.

A caatinga, que não é um ambiente nosso. 0 da imersão, eu acho que é o... seria o ponto principal, vamos assim dizer, não é; de você conhecer a flora da caatinga, conhecer os fatores, as populações, e todo o complexo ali dentro". (CAA1)

É, porque tem aquelas histórias de educação, se você só lê, você, o seu aprendizado é pouco, 10\%; se você lê e interage, se você lê é chamado para... ou se você lê, você é chamado, e você interage, você vai aumentando a sua capacidade de aprendizado, de absorção do conhecimento ali. E, para mim, a imersão, ali, no caso, ele tem isso tudo, ele pode ver, ele pode ler, ele pode passear, ele pode sentir o cheiro, ele pode, não é, enxergar tudo. (CAA5)

O discurso expográfico pode estar mais ou menos legitimado em exposições, de acordo com as relações que foram estabelecidas entre instituições e agentes envolvidos na concepção desses espaços. Na "Estufa do Cerrado" foi contratada uma empresa de expografia, e ainda que a instituição sede e os agentes relacionados à área das ciências biológicas tenham tido maior poder de decisão final, houve de acordo com as entrevistas, uma relação de troca importante com as equipes de concepção da expografia. De acordo com membros dessa equipe, formas de apresentação e escolha de objetos foram sugeridas por eles e, por vezes, acabaram influenciando as decisões sobre o conteúdo científico, por exemplo na diminuição do tamanho dos textos, escolha de imagens e objetos interativos. Já na exposição sobre a Caatinga, a expografia foi realizada pelos próprios membros do projeto, pesquisadores e técnicos das áreas de botânica e educação ambiental da Fundação Zoo-botânica de Belo Horizonte. Nesse caso, o discurso expográfico advém mais da experiência prática da equipe do que da formação específica. No entanto, essa característica e a composição da equipe, contribuem para as relações serem mais horizontais entre os discursos científicos, educacionais e expográfico, explicando a maior presença de unidades de análise de graus mais fracos de classificação nessa exposição. 
Quanto ao discurso educacional, notamos que apesar de presentes em ambas exposições, ele está mais legitimado na exposição sobre a Caatinga, ainda que nas unidades de análise dessa exposição os elementos didatizantes sejam menos explícitos do que na outra exposição. Participaram da equipe de concepção da "Estufa da Caatinga Mineira" profissionais do Serviço de Educação Ambiental da instituição que abriga a exposição. De acordo com as entrevistas com os conceptores de conteúdo, a educação ambiental foi sempre um pilar do projeto, tanto por conta do financiamento ter sido feito por um prêmio para projetos educacionais em jardins botânicos, quanto pela própria missão institucional e ideologia dos envolvidos. Isso se reflete no principal objetivo do projeto e também nas escolhas de conteúdo e forma de apresentá-los. Ainda de acordo com os conceptores entrevistados, a preocupação em fazer textos de fácil acesso para os diversos públicos, definições de termos e conceitos e as imagens associadas, são aspectos associados à função educativa da exposição. Como foi dito anteriormente, essa exposição conta com menor quantidade de texto e esses utilizam linguagem mais simples, buscando trazer definições para termos de uso científico.

Muitos dos aspectos que visam auxiliar a compreensão de informações e da narrativa estão presentes também na exposição sobre o Cerrado, e são bastante evidentes na medida em que há um grande número de recursos textuais e imagéticos de caráter didatizante. Não obstante, como foi afirmado anteriormente, a narrativa da "Estufa do Cerrado" é baseada em aulas de campo de um dos conceptores, que é justamente um dos principais agentes detentores do poder no processo de concepção do discurso expositivo. 0 discurso educacional, no caso dessa exposição, está mais limitado às experiências práticas e menos legitimado na medida em que não houve a participação de profissionais das áreas de educação ao longo do projeto. Por outro lado, não podemos deixar de mencionar que para CER1 e CER2, um dos principais propósitos de conceber uma exposição sobre o Cerrado foi divulgar conhecimentos científicos sobre esse bioma, que apesar de presente no Estado de São Paulo, é menos conhecido pelo público amplo.

É, a ideia foi essa, além do que, o Cerrado é tão pouco conhecido, principalmente em São Paulo. Você fala de Cerrado em Goiás é uma coisa, mas falar de Cerrado em 
São Paulo é outra, pouca gente conhece, tem interesse e tal. Então seria uma forma também de torná-lo mais conhecido e atrair mais visitantes e tal, porque o Jardim Botânico precisa ter visitação. (CER1)

Como contrapartida das instituições, funcionários dos jardins botânicos participaram na produção da exposição. Destaque aos jardineiros que possibilitaram a realização da área de representação do ambiente natural, além de participar das coletas dos espécimes vegetais em remanescentes dos biomas. O tipo de vínculo desses agentes com os demais conceptores e com a instituição também contribui para que as relações entre os discursos técnicos e científicos sejam estabelecidas. Na "Estufa da Caatinga Mineira", funcionários da própria Fundação Zoo-botânica de Belo Horizonte participaram ainda, da produção do mobiliário e, em particular, da construção da casa de adobe, agregando ao discurso expositivo conhecimentos tradicionais das populações da Caatinga Mineira.

No que se refere às intradisciplinaridade (figura 4.25), a análise das relações entre os componentes (função, composição e estrutura) da biodiversidade do ponto de vista do termo nas ciências biológicas, mostra que na exposição "Estufa do Cerrado" as unidades que apresentam relações mais fracas (C- e C--) tem maior representatividade do que as fortemente classificadas. No entanto, essa diferença é pequena, conferindo um equilíbrio entre discursos com articulação entre os componentes da biodiversidade e aqueles que apresentam apenas um dos aspectos do termo.

$\mathrm{Na}$ exposição sobre a Caatinga, as unidades de classificação forte representam dois terços do total e mostram que há baixa intradisciplinaridade. Isso significa que a mensagem que emerge da totalidade das unidades de análise tem reduzida relação entre os componentes da biodiversidade e portanto, em uma abordagem menos complexa do termo.

Considerando as duas exposições, a baixíssima quantidade de unidades de análise com classificações muito fracas denota que a abordagem biológica da biodiversidade, raramente apresenta relações entre todos os componentes, dificultando o acesso a conteúdos mais abstratos e com maior nível de complexidade.

A análise por módulo mostra que as unidades com os diferentes graus de 
relação entre os componentes da biodiversidade não estão distribuídas de forma homogênea. Há módulos com maior intradisciplinaridade, enquanto há módulos em que todas as unidades tratam apenas de um dos componentes. A ausência de um padrão entre módulos, evidencia também que não há uma ampliação da intradisciplinaridade ao longo da exposição.

$\mathrm{Na}$ análise da intradisciplinaridade contabilizamos ainda a frequência de cada componente da biodiversidade nas unidades fortemente classificadas $(\mathrm{C}+$ ) e das intersecções entre eles nas relações fracas (C-) e muito fracas (C--), cujos resultados estão apresentados na figura 4.26. Notamos que há maior presença dos aspectos composicionais da biodiversidade, relacionados em geral ao clima e à ocupação espacial. Essa característica pode estar relacionada a alguns fatores, entre eles destaca-se a maior quantidade de conhecimento acumulado sobre composição e estrutura em vários níveis de diversidade. Ainda que o número de pesquisas que incluem as funções da biodiversidade tenham crescido nas últimas décadas, os dados sobre a composição e estrutura são, geralmente, necessários para análises dos aspectos funcionais da biodiversidade (MAZZAROLO, 2005).

A presença mais frequente de um ou outro componente da biodiversidade pode ter relação também com a área de pesquisa dos conceptores de conteúdo das exposições, nos casos analisados a maioria dos agentes são especialistas em botânica ou ecologia dos biomas. As definições científicas de biodiversidade de acordo com Sarkar (2002) dependem do contexto e enfatizam aspectos distintos dos conjuntos de organismos que compõem a biosfera. As definições passam ainda pela opção entre o rigor conceitual e as possibilidades de medição e delimitação (LEWINSOHN e PRADO, 2000). Oliveira e Marandino (2011) afirmam que o conceito de biodiversidade em contextos científicos está ligado com a linha de investigação desenvolvida pelos pesquisadores. 0 trabalho de Oliveira (op. cit.) mostra ainda que as abordagens de biodiversidade utilizadas pelos pesquisadores nas atividades docentes mantêm relação com suas áreas específicas de investigação.

No contexto expositivo, um fator a ser considerado quando se trata da comunicação da biodiversidade para o público não especialista é que os aspectos da composição referem-se, em grande parte, aos conteúdos mais concretos e de 
mais fácil apreensão sobre a biodiversidade, como exemplos de espécies, tipos de ecossistemas e de paisagens de uma região.

O UEBT diversity barometer ${ }^{48}$ realizado entre 2009 a 2015 em 16 países, incluindo o Brasil, mostra que as concepções sobre biodiversidade são para um terço das pessoas reduzidas à variedade de vegetais e animais e exemplos de ecossistemas. Lude (2010), em sua pesquisa realizada com professores e alunos do ensino superior na Europa, concluiu que para a maior parte deles (80\%) as ideias sobre biodiversidade abrangem apenas a variedade de espécies. 0 trabalho de Bujis e colaboradores (2008) realizado com moradores do entorno, gestores e visitantes de unidades de conservação na Alemanha, mostrou que entre os indivíduos não-especialistas, principalmente visitantes e moradores do entorno, a concepção de biodiversidade é restrita à variedade de espécies e de habitats. Uma concepção semelhante foi encontrada entre os visitantes de museus de história natural, para os quais a pluralidade de organismos representa a biodiversidade (MARANDINO et. al., 2012).

Dentre as unidades fracamente classificadas (C-), as relações entre composição e função são as mais frequentes na "Estufa do Cerrado" seguidas pelas relações entre composição e estrutura. Esses dois tipos de relações são igualmente frequentes na "Estufa da Caatinga Mineira". Esses dados reforçam a forte presença dos aspectos composicionais nas exposições. Isso mostra que as exposições podem contribuir para que os visitantes percebam a biodiversidade para além dos aspectos composicionais do termo, ampliando as possíveis definições com a inclusão dos aspectos funcionais.

Nota-se também que a biodiversidade funcional, seja separadamente ou nas relações com outros componentes, é bastante frequente nas exposições. Aspectos relacionados à função da biodiversidade ocorrem nas unidades em que são tratadas interações das espécies com o ambiente ou das relações ecológicas estabelecidas por elas. São especialmente frequentes na exposição sobre o Cerrado, as descrições de espécies endêmicas ou de grande importância no

\footnotetext{
${ }^{48}$ O Barômetro da Biodiversidade vem sendo realizado desde 2009 pela UEBT, para avaliar a conscientização sobre biodiversidade em todo o mundo. Além de levantar informações sobre consumo consciente para empresas, permite acompanhar as metas de conscientização global sobre biodiversidade das Nações Unidas para 2020.
} 
bioma. Em algumas unidades de análise, a diversidade funcional é tratada do ponto de vista dos serviços ecossistêmicos e interações do homem com a natureza, especialmente na exposição sobre a Caatinga. Essas características têm forte ligação com o contexto de exposições na medida em que a descrição das espécies e/ou das interações estão mais baseadas em exemplos e fatos, portanto de mais fácil compreensão pelo público. Além disso, como foi mencionado anteriormente, podemos relacionar esse tipo de abordagem às áreas de conhecimento dos conceptores, especialmente a ecologia.

Vale destacar ainda, que apesar do componente estrutural da biodiversidade ter sido menos frequente nas unidades analisadas, as representações naturais presentes em exposições de imersão propiciam as relações entre composição e estrutura, pois apresentam espécies relevantes do bioma e a distribuição delas no ambiente. A análise de representações de ambientes por meio de dioramas realizado por Oliveira e Marandino (2012) mostra que essas montagens retratam principalmente a diversidade de espécies e ecossistemas, que inclui tanto os aspectos composicionais, quanto estruturais da biodiversidade, justamente por conta da possibilidade de representar tridimensionalmente o ambiente. Vale ressaltar que os dioramas apresentam ainda interações entre as espécies e/ou delas com o ambiente, contribuindo dessa forma para que a biodiversidade contenha aspectos funcionais.

Um aspecto final sobre a análise da intradisciplinaridade é a presença do ser humano no conceito de biodiversidade. A frequência de unidades de análise que tratem da diversidade de culturas e das formas como utilizam e interagem com os ambientes e outras espécies, entre os componentes de estrutura, função e composição, é maior na exposição sobre a Caatinga. Isso porque, como foi dito acima, havia entre a equipe de concepção dessa exposição uma intenção de retratar as culturas e comunidades que habitam a região da Caatinga Mineira. No entanto, nas duas exposições, a perspectiva de apresentar o homem como parte da natureza está circunscrita a um módulo, isto significa que esse viés não permeia o discurso expositivo como um todo, ainda que haja a intenção e seja dada importância, por parte dos conceptores, a essa visão.

A integração de pesquisas e dados sobre os diferentes aspectos da biodiversidade (composição, estrutura e função) é mais recente e faz parte de 
projetos e plataformas que visam a compreensão de cenários mais amplos e tomada de decisões tanto em âmbitos científicos como políticos. Atualmente, a Plataforma Intergovernamental de Biodiversidade e Serviços Ecossistêmicos/IPBES 49 busca associar esses aspectos a questões sobre desenvolvimento sustentável, conservação da biodiversidade, serviços ecossistêmicos. De acordo com Lude (2010), essa abordagem mais integrada acerca da biodiversidade, e que inclui o ser humano como mais uma espécie e/ou na relação com a natureza, está mais ligada às temáticas de desenvolvimento sustentável, tanto em currículos quanto em práticas pedagógicas, que muitas vezes valorizam atividades em espaços "fora" de sala de aula. Na pesquisa realizada por Bujis e colaboradores (2008), definições mais amplas de biodiversidade que incluem a diversidade cultural foram pouco frequentes entre o público de não especialistas, ocorrendo com maior frequência entre o público mais especializado, como os gestores de recursos naturais de Unidades de Conservação. A análise realizada por Marandino e colaboradoras (2015) sobre a compreensão da biodiversidade em museus, mostrou que a abordagem humana do termo não foi mencionada pelos visitantes.

Os resultados da análise das relações entre o ser humano e a natureza nos discursos expositivos, apresentados na figura 4.29, mostram que a perspectiva mais integradora dessas relações tem pouquíssima representatividade nas exposições. As unidades de análise de classificações mais fracas (C- e C--), que vão além da relação do ser humano como observador da natureza, representam apenas um terço da total. Isso significa que grande parte do discurso expositivo aborda a biodiversidade desde uma visão da natureza intrínseca ou de acordo com Mace (2014) "a natureza por si". Vale lembrar que essa visão pode transmitir a ideia dos atributos e valores da biodiversidade pelo que ela é, sem incluir no entanto, os benefícios dela para o ser humano. Ainda de acordo com a autora, essa abordagem não exclui necessariamente a ideia de que nossa espécie não é mais importante que as outras.

\footnotetext{
${ }^{49}$ A Plataforma-política da ciência Intergovernamental sobre Biodiversidade e Serviços dos Ecossistemas (IPBES) é um organismo intergovernamental independente criado para reforçar a interface entre ciência e política para a biodiversidade, serviços ambientais, conservação e uso sustentável da biodiversidade, bemestar humano a longo prazo e desenvolvimento sustentável.
} 
A maior presença das unidades de classificações fortes reflete também a forma descritiva e detalhada que se apresentam as informações, especialmente sobre as espécies e fisionomias, remetendo-nos às características dos discursos da história natural. Vale destacar que as instituições museológicas de história natural têm relação com a consolidação da ciência moderna (LOPES, 1997) e, assim, essas instituições estruturaram-se a partir de uma dicotomia entre natureza e cultura. No entanto, conforme Haraway (1992), a suposta ausência de intervenção dos humanos sobre os espécimes naturais que compõem as coleções e exposições em museus pode ser questionada, pois é, geralmente, a partir de um modelo ou concepção humana, que tais objetos da natureza acabam por estar presentes nos espaços museais.

As unidades de análise fracamente classificadas (C-) que se referem às relações de oposição e benefícios entre homem e natureza, encontram-se em maior frequência nos módulos finais das exposições. São justamente esses módulos que tratam das questões sobre a conservação da biodiversidade, enfatizando aspectos sobre a vulnerabilidade dos ambientes frente às interferências humanas e os serviços prestados pela natureza. As abordagens fatalistas e utilitaristas aparecem frequentemente entre as visões do público sobre biodiversidade e sobre as relações entre humanos e natureza. A análise de Fischer e Young (2007) com o público visitante de ambientes naturais na Escócia, mostrou que para o público as características da biodiversidade ressaltam aspectos negativos e/ou positivos da relação humana com a natureza. Outro aspecto importante da pesquisa das autoras é que para os grupos que têm uma interação mais frequente com a natureza, a ausência de influência humana sobre a biodiversidade é uma característica particularmente positiva. 0 trabalho de Bujis e colaboradores (2008), baseado nas representações sociais da biodiversidade em que se consideram opiniões sobre a relação homem-natureza inseridas no conhecimento, experiência e práticas das pessoas, mostrou que essas representações consistem em uma inter-relação entre diferentes abordagens da biodiversidade, tais como benefícios e funções, atributos e valores e intervenções humanas. De acordo com os autores, essas representações propiciam a compreensão das visões e atitudes acerca da gestão da biodiversidade. Nessa mesma linha, a pesquisa de Kaltenborn e colaboradores 
(2015) ressalta que as visões do público sobre a biodiversidade geralmente excluem o ser humano. No entanto, quando se trata da perda da biodiversidade, a ação humana foi bastante frequente nos discursos do público. Assim, como afirmam os autores, os aspectos da interação entre a nossa espécie e a natureza são fatores essenciais para determinar as atitudes dos indivíduos em relação à gestão da biodiversidade.

Na exposição sobre o Cerrado as unidades de classificação muito fraca(C-) são aquelas que tratam das interações entre as comunidade tradicionais e o bioma. 0 mesmo ocorre na "Estufa da Caatinga Mineira", na qual essas relações ocorrem nas unidades do módulo 3, no qual são tratados aspectos da cultura do Sertanejo. Nesses casos, as mensagens incluem processos sócio-ecológicos, abordados desde um ponto de vista do ser humano como parte da natureza. Ainda que consideremos a potencialidade dessa abordagem para a apresentação da biodiversidade de forma mais integradora e que permita o acesso a conteúdos sobre biodiversidade mais complexos, é importante ressaltar o descolamento dessa visão em relação à realidade da maior parte do público. Ao restringir as visões mais multifacetadas das relações entre humanos e natureza às populações tradicionais, podem ser reforçadas as ideias que distanciam outras populações e culturas da natureza.

No último módulo da "Estufa da Caatinga Mineira" a abordagem "Natureza com Seres Humanos" (relações muito fracas) estão associadas ao manejo da biodiversidade, abrangendo ações no âmbito da política, economia, ciência e educação. Caracterizando a multidimensionalidade dessas relações entre a nossa espécie e a natureza e as ações de conservação que tendem a permear diversos setores da sociedade.

Destacamos que as diferenças entre as abordagens podem não ser claras, além disso, elas convivem atualmente. Para Mace (2000), a categoria no qual o foco está nos humanos pode ser bastante semelhante àquela em que essa relação é muito distante (natureza intrínseca). Isso se deve ao fato de ambas incluírem esperanças e desejos acerca do ambiente em que querem viver e aquele que deixarão para as próximas gerações. A autora reforça também que ainda que a abordagem mais integradora seja mais condizente com o caráter multifacetado das relações entre nós e o ambiente, há um riso decorrente dessa própria 
característica, pela dificuldade em mensurar as múltiplas variáveis e agregar os diversos conhecimentos e discursos.

No que se refere ao nível de exigência dos conteúdos, notamos pela análise dos resultados apresentados na figura 4.32, que as relações interdisciplinares contribuem de forma mais significativa para a complexidade do discurso expositivo sobre biodiversidade. Conforme dito anteriormente, vários discursos estão em jogo nas exposições, ainda que as relações entre eles possam ser mais ou menos fracas, elas são condições essenciais para a existência de uma narrativa temática em um contexto com as especificidades do objeto e tridimensionalidade. Além disso, chamamos a atenção para a própria temática, propícia às relações entre diferentes conhecimentos e saberes.

De forma geral, considerando as especificidades da educação em museus no que se refere ao tempo de permanência nas exposições, aos objetos presentes, à quantidade de textos e informações, e especialmente quanto à heterogeneidade dos visitantes (níveis socioeconômicos, culturais, idade, escolarização etc.), podese afirmar que as exposições contribuem para o acesso ao conhecimento sobre biodiversidade relativamente complexo. Assumimos a necessidade de que esses espaços abordem temas complexos como a biodiversidade, permitindo que o público acesse conhecimentos científicos e competências de diferentes níveis de complexidade, e sobretudo permitindo a integração dos conteúdos.

Vale por fim destacar que a análise realizada levou em consideração as potencialidades dos discursos expositivos na promoção do acesso a conteúdos de maior complexidade sobre a biodiversidade. No entanto, quanto ao fato de se os visitantes compreendem ou acessam tais conhecimentos, novas pesquisas devem ser realizadas, contribuindo para ampliar o panorama dos processos e práticas da educação em museus. 


\section{Considerações finais}

O presente trabalho propiciou uma análise sociológica do processo de produção de exposições de imersão, com base na teoria de Basil Bernstein. A pesquisa caracterizou os agentes e agências que compõem os campos recontextualizadores, além de identificar os textos oficiais acerca das temáticas das exposições. Nesta investigação foi também caracterizado o discurso expositivo das exposições de imersão, por meio da análise do "o que" (complexidade dos conhecimentos científicos e competências cognitivas) e do "como" (relações entre discursos).

Os biomas da Caatinga e do Cerrado são os temas centrais das exposições "Estufa do Cerrado" e "Estufa da Caatinga Mineira" analisadas nesta investigação. Nos módulos expositivos, aspectos específicos ou subtemas acerca desses ambientes são apresentados por meio da representação do ambiente natural, objetos, painéis com textos e imagens, além de outros tipos de aparatos.

A análise foi realizada com dados de entrevistas, observações e documentos. Vale lembrar que os instrumentos de coleta utilizados nas entrevistas e observações foram elaborados com base na teoria de Basil Bernstein. Os roteiros de entrevista e observação possuem questões que estão diretamente relacionadas aos instrumentos que foram desenvolvidos e utilizados na análise do discurso expositivo.

Em relação ao processo de produção do discurso, destacamos que não há um discurso oficial único no caso dos museus, haja vista a variedade de tipologias e afiliações dessas instituições. Assim como foi afirmado por Martins (2011), nossa análise mostra também que o campo de recontextualização dos museus (CRO) é composto por diferentes agentes e agências. Além da atuação do Ministério da Cultura (Minc)/Instituto Brasileiro de Musues (Ibram) e do Ministério da Ciência, Tecnologia, Inovação e Comunicações (MCTIC), identificados por Martins (op. cit.), e do Ministério da Saúde (MS), identificado por Marandino (2015), destacamos, nesta pesquisa, a atuação do Ministério do Meio Ambiente (MMA) e órgãos a ele vinculados, no CRO dos museus. Além do MMA, outros ministérios e entidades são responsáveis por produzir e implementar políticas públicas relacionadas à educação em espaços museais como os jardins botânicos, tais 
como o Programa Nacional de Educação Museal - PNEM (Ibram/MinC), Programas de Popularização da Ciência (MCTIC) e Política Nacional de Educação Ambiental - PNEA (MMA).

Um ponto importante para a implementação dessas políticas e programas é a atuação dos ministérios e suas entidades, além das agências correlatas em âmbito estadual e municipal, no financiamento de ações de educação e divulgação em museus. Outras agências ligadas ao campo da economia e ainda as organizações não-governamentais também atuam no financiamento na área da educação museal, como a Fundação Vitae, Botanic Gardens Conservation International (BGCI), entre outras. Consideramos que os discursos produzidos no campo de atuação dessas agências são recontextualizados na produção dos discursos pedagógicos, tais como os discursos expositivos.

Desse modo, considerando a tipologia da instituição que abriga as exposições analisadas e a temática que apresentam, destacamos na composição do CRO o Ministério do Meio Ambiente (MMA) e órgãos vinculados, tais como o Instituto Brasileiro de Meio Ambiente (IBAMA), o Instituto Chico Mendes de Conservação da Biodiversidade (ICMBio) e o Jardim Botânico do Rio de Janeiro (JBRJ), bem como as secretarias de estado e município de meio ambiente. Para além delas, conforme apresentamos no capítulo 3, atuam, via programas específicos que abrangem ações de divulgação e educação sobre biodiversidade, o Ministério da Ciência, Tecnologia, Inovação e Comunicações (MCTIC) e o Conselho Nacional de Desenvolvimento Científico e Tecnológico (CNPq), entidade vinculada ao ministério.

É possível perceber nas políticas e programas dessas agências que o papel educativo dos jardins botânicos, assim como o dos zoológicos, aquários e UCs, está associado à educação ambiental, educação para conservação e/ou educação para o desenvolvimento sustentável. Essa característica fica nítida na denominação dos setores educativos dos jardins botânicos, como por exemplo, o Setor de Educação Ambiental (SEA) da FZB-BH, Núcleo de Pesquisa em Educação para Conservação do JBSP, ou ainda o Núcleo de Educação Ambiental do JBRJ. Isso mostra a importância do tratamento das questões ambientais nas ações educativas realizadas por essas instituições. 
Considerando o recorte temático desta investigação, notamos que na Política Nacional da Biodiversidade (PNB), programas do MMA e MCTIC para a biodiversidade e conservação, e nos programas específicos dos biomas da Caatinga e Cerrado, a educação pode ter maior ou menor destaque. Geralmente, as linhas de ação contemplam de forma conjunta e bastante sintética a educação para a conservação e divulgação científica.

Ainda que tenhamos identificado diferentes documentos oficiais, as entrevistas realizadas mostraram que os conceptores de conteúdo da "Estufa do Cerrado" não utilizaram, na concepção da exposição, documentos advindos das agências que atuam no CRO. Já os conceptores da "Estufa da Caatinga Mineira", apesar de não citar um documento específico, afirmaram que foram consultadas publicações do MMA sobre a Caatinga e publicações do órgão internacional de jardins botânicos (BCGI) sobre Educação Ambiental.

A análise realizada aponta também para a ampliação do campo de recontextualização pedagógica (CRP) dos museus. Conforme apontou Martins (2011), esse processo começou a ocorrer de forma mais acentuada a partir da década de 1960 com a estruturação dos setores educativos das instituições museais. Outro aspecto interessante apontado pela autora é o surgimento de associações especificas de educação em museus, tais como o Comitê Internacional para a Educação e Ação Cultural (CECA-ICOM) e as Redes de Educadores de Museus (REMs). No que concerne os jardins botânicos, destacamos também o surgimento do Botanic Gardens Conservation International (BGCI) e, no Brasil, da Rede Brasileira de Jardins Botânicos (RBJB), associações que têm em suas frentes de atuação, a educação ambiental e a educação para a conservação. Outros aspectos relacionados à ampliação do CRP dos museus são a criação de cursos de graduação e pós-graduação na área de museologia e patrimônio, além do aumento no número de publicações voltadas para profissionais de educação museal, principalmente a partir da década de 2001.

No que se refere ao processo de recontextualização dos discursos expositivos analisados, identificamos que na "Estufa do Cerrado" do JB de SP atuaram com maior poder de decisão, agentes que compõem o campo do controle simbólico na área das Ciências Biológicas, pesquisadores das áreas de ecologia e botânica do Cerrado. Além deles, outros agentes e discursos estiveram 
presentes e participaram do processo de concepção da exposição, estabelecendo relações com o discurso científico. No caso dessa exposição, há um menor número agentes e campos recontextualizadores, uma vez que parte dos agentes que atuam na produção do conhecimento são os mesmos que o recontextualizaram. Com isso, poderíamos apontar para um menor número de recontextualizações, que influenciaram na dinâmica de manutenção de um discurso mais próximo do científico nas mensagens da exposição.

A sobreposição entre agentes que atuam nos campos recontextualizadores em ações educativas de museus foi também apontado no trabalho de Martins (2011). Em seu trabalho a autora identificou que os educadores das exposições estudadas participavam como agentes tanto no campo de recontextualização oficial quanto pedagógica. Na presente pesquisa, destacamos o papel de outros agentes e discursos do campo de recontextualização pedagógica que participaram com maior ênfase do processo de produção da "Estufa da Caatinga" da FZB-BH, especialmente aqueles relacionados à expografia. De acordo com Marandino (2014), dar voz ou não aos demais discursos, além do científico, é uma decisão política e de gestão da própria instituição e recebe influência dos órgãos financiadores, das políticas governamentais de cultura e educação e dos grupos de controle que atuam no campo recontextualizador oficial ou no campo do controle simbólico.

A análise do processo de produção do discurso expositivo da "Estufa da Caatinga" mostra, por sua vez, uma participação mais partilhada entre os agentes que aturam na recontextualização pedagógica. Destaca-se, assim, o envolvimento de diversos setores da instituição, incluindo o Setor de Educação Ambiental, durante todas as fases do processo.

Outro aspecto interessante sobre a produção da exposição sobre a Caatinga diz respeito às viagens de coleta e às ações educativas realizadas junto às comunidades que habitam regiões da Caatinga Mineira. Ainda que a equipe de concepção da exposição tivesse desde o princípio uma preocupação com a inserção da cultura na exposição, essas viagens tiveram um papel ímpar na compreensão das especificidades culturais e dos saberes locais, fazendo com que esses aspectos sejam bastante valorizados no discurso expositivo.

Destacamos ainda sobre os processos de recontextualização que geraram 
os discursos expositivos, a questão da regulação por meio dos financiamentos e afiliações. Conforme apontamos anteriormente, as exposições uma vez sediadas em jardins botânicos possuem em algum grau uma regulação externa das agências que administram as instituições. No caso do jardim botânico de São Paulo há o vínculo com o Instituto de Botânica, e esse por sua vez faz parte da estrutura da Secretaria de Estado do Meio Ambiente (SMA). Por conta dessa vinculação foi possível obter a verba de compensação ambiental que financiou a exposição. No entanto, conforme apontou a conceptora entrevistada (CER1), não houve qualquer tipo de interferência da SMA ou do Instituto na concepção e implementação do exposição. Já a FZB-BH faz parte da administração indireta da prefeitura de Belo Horizonte, estando vinculada à secretaria municipal de meio ambiente. Nesse caso, a forma de financiamento foi realizada via um programa de investimento da associação BGCI em parceria com a iniciativa privada, e segundo os conceptores, o projeto teve que se adequar às diretrizes da chamada, não havendo outras formas explícitas de regulação.

Uma das características que mostra a importância de se realizar a análise de discursos expositivos é que as exposições são as formas fundamentais de comunicação do museu com seus públicos. Vale lembrar que, entre as missões dessas ações, estão a de promover experiências educacionais, mas também de legitimar a importância dos museus e exposições junto ao público (LOOMIS, 1987; DEAN, 1994, 1996; DAVALLON, 2010).

Além de comunicar a temática intencionada para uma grande variedade de públicos, as exposições trazem visões sobre as ideias e as formas de apresentá-las ao visitante. As mensagens expressas pelo discurso expositivo são a realização dessas visões, que incluem o que é legítimo e as formas legítimas de transmití-los (BERNSTEIN, 1996).

Considerando que o foco das exposições estudadas é o público espontâneo, que possui diferentes graus de conhecimento sobre biodiversidade, os índices de complexidade dos conteúdos revelaram que as exposições podem contribuir para o acesso dos vários tipos de visitantes às competências e conhecimentos mais simples e também aqueles razoavelmente complexos. Deste modo, em um contexto não-formal de educação, especialmente ao considerarmos o papel dos museus no processo de educação ao longo da vida, avaliamos que as 
exposições têm importante potencial para o processo de aquisição de conhecimentos sobre biodiversidade.

Dois aspectos fundamentais na concepção das exposições vieram à tona por meio da análise dos discursos. Em primeiro lugar, de acordo com Bernstein (1996, 2000), todo discurso e seus textos são ideologicamente reposicionados nos processos de recontextualização, assim, os objetivos dos conceptores, suas posições em relação à equipe e à instituição que abriga as exposições contribuíram em maior ou menor grau para a mensagem do discurso expositivo e para a manutenção das relações de poder e controle embutidas nele.

Em segundo lugar, ressaltamos as especificidades do contexto expositivo. A importância dos objetos, tridimensionalidade e tempo são aspectos cruciais para o reposicionamento dos discursos oriundos das áreas de conhecimento originais e/ou dos processos de recontextualização ocorridos na dimensão da produção dos discursos. Nas exposições estudadas, essas especificidades contribuíram, por um lado, para que o conhecimento científico recontextualizado tenha sido muito simplificado por conta da quantidade de textos e da heterogeneidade dos públicos. Por outro lado, sobressaem-se possibilidades de se tratar um tema complexo como a biodiversidade, mobilizando conceitos e competências de maior nível de complexidade por meio de estratégias expositivas das exposições de imersão que associam elementos textuais, imagens, objetos e representações do ambiente natural. As exposições analisadas potencializam também a sensibilização do indivíduo por meio de estímulos presentes nos ambientes naturais, abrindo novas possibilidades para a construção de conhecimentos, desenvolvimento de competências cognitivas, afetivas e atitudes.

Os trabalhos de Botelho e Morais $(2003,2004)$ sugerem que a interação de alunos com aparatos expositivos são instrumentos potenciais para a compreensão de conceitos em grupos socialmente diversificados. Contudo, segundo Bourdieu e Darbel (2003), a escola e museus que deveriam ser responsáveis pelo crescimento cultural do indivíduo, acabam por atuar como legitimadores de uma cultura elitizada, contribuindo para a manutenção de um sistema que dá vantagens àqueles que já se favorecem de vários benefícios e distancia sujeitos mais desfavorecidos culturalmente. Esse potencial dos museus 
em dar acesso ao conhecimento e, ao mesmo tempo, privilegiar os grupos mais favorecidos que estão mais próximos da cultura elitizada, revela os desafios e as contradições do papel educativo dos museus na sua relação com o público.

Chamamos atenção, assim, para a importância dos museus na democratização do acesso ao conhecimento científico. Para tal, é essencial que museus e outras instituições culturais ampliem seus públicos e contribuam para que esses detenham as regras que os permitam acessar as mensagens legítimas presentes nesses espaços. Partimos do pressuposto que os museus devem contribuir para que os cidadãos tenham acesso ao conhecimento poderoso, que de acordo com Galian e Louzano (2014), permita ver o mundo, interpretá-lo e que abra a possibilidade de transformá-lo.

De acordo com Galian (2011), a baixa exigência conceitual, que envolve a complexidade das competências, conhecimentos e relações entre discursos, limita a compreensão do mundo e das oportunidades de pensar em outras possibilidades de configuração do real. Ao permitir o acesso a uma diversidade de conhecimentos científicos e habilidades de pensamento de diferentes níveis de complexidade, as exposições contribuem para que, de acordo com Martins (2003), possam influenciar nas decisões político-sociais que envolvam a ciência e suas aplicações e "marquem posição diante do discurso do poder embutido nas relações sociais" (GALIAN, 2011 p. 765).

No que se refere à interdisciplinaridade, notamos que a mensagem da exposição "Estufa do Cerrado" valoriza menos as relações entre os diversos saberes e/ou áreas de conhecimento, quando comparada à mensagem presente na exposição sobre a Caatinga. No entanto, há que se ressaltar que somando as relações fracas e muito fracas, ambas as exposições possuem mensagens em que há interdisciplinaridade. Esse resultado, conforme apontamos na discussão, é devido tanto à temática das exposições, quanto às características do contexto em que se estabelecem diversas relações entre os discursos científico e expográfico.

Ao aprofundar a análise das relações entre os saberes e/ou áreas do conhecimento, veio à tona na exposição sobre o Cerrado a forte presença do discurso científico da biologia, especialmente da área da botânica e ecologia. Apontamos que o estatuto elevado dessas disciplinas está relacionado ao processo de recontextualização com a participação de agentes do campo 
simbólico, notadamente pesquisadores de referência em ecologia e botânica do Cerrado. Além disso, as agências que participaram desse processo, no que se refere ao financiamento e à sede da exposição, constituem órgãos governamentais do meio ambiente e pesquisa em botânica, respectivamente.

Vale lembrar que de acordo com Bernstein (2000) o campo simbólico é constituído por agentes e agências que operam discursos dominantes, esses por sua vez, regulam relações sociais e formas de consciência. Destacamos, com isso, as relações de poder que estão embutidas na mensagem da exposição do Cerrado, o predomínio dos discursos das áreas especializadas pode ser explicado por conta desses conhecimentos e das relações entre eles serem aqueles legitimados na sociedade, uma vez que originam-se no campo simbólico, dominado por uma elite que tem acesso ao conhecimento poderoso. Por sua vez, em um processo semelhante a um feedback, o discurso expositivo acaba por legitimar esses conhecimentos e relações.

A maior valorização da interdisciplinaridade presente na mensagem global da exposição "Estufa da Caatinga Mineira" está também relacionada ao processo de recontextualização que gerou o discurso expositivo. Nesse caso, a concepção foi desde o princípio bastante partilhada entre os agentes e a forma de financiamento, por meio de um prêmio aos projetos de educação para a conservação, o que propiciou dar "voz" a outros discursos. Destacamos a presença das questões sobre a cultura regional da Caatinga Mineira, agregando ao discurso expositivo saberes e conhecimentos de outras áreas, para além do discurso científico e expográfico.

Outro aspecto que merece destaque são as relações entre os componentes da biodiversidade, apontando para uma complexidade intermediária do termo científico nas exposições. Especificamente quanto à exposição sobre o Cerrado, notamos que há um equilíbrio entre as unidades que apresentam apenas um dos componentes do termo e aquelas em que há dois ou mais componentes. Esses resultados mostram que é possível tratar da biodiversidade em exposições com abordagens de maior complexidade do termo, fruto das pesquisas que aliam os diferentes componentes e ainda os relacione a saberes e conhecimentos de outras áreas.

Ainda que o discurso expositivo da "Estufa da Caatinga Mineira" tenha, em 
grande parte, uma mensagem menos integradora quanto às relações entre seres humanos e a natureza, a importância dada à cultura do Sertanejo influenciou o enfraquecimento das fronteiras no que se refere a essas relações. Uma mensagem menos integradora também ocorre na exposição sobre o Cerrado em que há predomínio da abordagem "natureza intrínseca". De forma geral, os resultados desse indicador chamam a atenção para a necessidade de que se adotem discursos mais atuais, que vão além do significado do termo na ciência, adotando vieses sociais, políticos e econômicos na abordagem da biodiversidade, revelando sua complexidade e os fatores que implicam na sua compreensão e conservação.

A maior presença da abordagem "natureza intrínseca" evidencia, nas mensagens expositivas, o distanciamento entre o homem e a natureza. De acordo com Fisher e Young (2007), são necessárias abordagens discursivas sobre a biodiversidade que reconheçam e abracem as visões multifacetadas e integradas, no sentido de propiciar maior engajamento do público nas questões ambientais.

Vale lembrar ainda que as relações entre humanos e natureza incluem aspectos ligados aos componentes reguladores do discurso, nesse caso, atitudes e valores sobre a biodiversidade e conservação. De acordo com Bernstein (1996), o discurso pedagógico é definido pela relação entre o discurso instrucional e o discurso regulador. Esse último diz respeito às competências sócio-afetivas, aquisição de valores e normas de conduta (MORAIS e NEVES, 2007b). 0 discurso regulador está ligado ao contexto e sofre influência dos discursos dos vários níveis do aparelho pedagógico.

Tendo em vista as características afetivas e de valores que permeiam as relações entre humanos e natureza nas exposições analisadas, levantamos dois aspectos a serem discutidos sobre a existência de um discurso regulador específico que exerce influência sobre as mensagens dos discursos expositivos. 0 primeiro deles está ligado ao contexto das exposições, sediadas em instituições com forte apelo à conservação da biodiversidade. Nesse caso, será possível considerar que o discurso da conservação constitui uma base moral desses contextos, influenciando portanto, na regulação do discurso instrucional? 0 segundo aspecto está relacionado à possível influência do discurso regulador geral sobre o discurso expositivo. Haverá um discurso regulador específico 
influenciado pelo regulador geral, dado que há entre os princípios gerais da sociedade ampla aceitação à ideia de que biodiversidade precisa ser conservada?

No que tange à dimensão interacional dos contextos de reprodução dos discursos expositivos é importante destacar os aspectos relacionados às regras discursivas. As características da prática educativa em museus determinam formas específicas das relações entre a exposição, considerada como mediadora dos conteúdos e os visitantes. De acordo com Bernstein (1996), as regras discursivas regulam as interações entre os sujeitos ao nível da transmissão do discurso. Essas regras dizem respeito ao controle que os indivíduos têm sobre a seleção de conteúdos, sequência, ritmo e avaliação.

Assim como em outros contextos educacionais, a seleção dos conteúdos em exposições é geralmente realizada pelos conceptores ou curadores, e o mesmo ocorreu nas exposições por nós estudadas. 0 trabalho de Botelho e Morais (2004) em centro de ciências mostrou que, no que se refere às relações de controle, em particular à seleção dos temas e conteúdos, o público visitante não tem qualquer participação na escolha dos temas/conteúdos, a seleção é de inteira responsabilidade dos conceptores, assim o enquadramento é forte.

Já a sequência em que os conteúdos são apresentados pode variar bastante entre as tipologias de museus e de temáticas. Nas exposições analisadas, a sequência de apresentação dos conteúdos está determinada pela estrutura expositiva com um caminho pré-determinado. Contudo, isso não significa que o visitante não possa ter algum controle sobre essa sequência e quanto aos conteúdos que vai se ater. As relações mais fracas entre as regras discursivas dizem respeito ao tempo. No trabalho de Agostinho e Morais (op. cit.), os autores mostraram que o controle do público sobre o tempo e a ordem de apropriação dos conteúdos é maior, assim o enquadramento nesses casos tende a ser mais fraco. Seria relevante estudar como os visitantes das duas estufas investigadas por nós se apropriam dos conhecimentos e que graus de controle possuem sobre formas e percursos expositivos.

Ainda que a exposição seja considerada uma das ações educativas realizadas em museus, configurando como mediadora da comunicação com o público, destacamos a importância dos processos de mediação humana entre a exposição e os visitantes, que podem conferir outras possibilidades de 
recontextualização do discurso expositivo. Conforme apontam Alves e Morais (2015), a atividade do professor como mediador das práticas pedagógicas em contextos escolares pode propiciar um espaço para incremento da complexidade dos conhecimentos no nível da reprodução do discurso. No caso dos museus, recursos como a ação de mediadores, o apoio de folders e guias de visitação, materiais para professores e alunos, dentre outros, podem também constituir importantes estratégias de mediação, ampliando os recursos para a negociação de significados e formas de usufruir as exposições.

Mesmo que a identificação do papel do mediador humano e análise de materiais não esteja entre os objetivos desta pesquisa, é pertinente questionar se e como a atuação dos educadores e/ou de materiais educativos podem constituir mecanismos para o incremento do nível de exigência dos conteúdos em exposições. No que concerne as exposições analisadas, destacamos que ambas contam com educadores para atendimento de grupos organizados. Para o público espontâneo, o atendimento varia conforme a disponibilidade de educadores. Quanto aos materiais educativos, foram produzidos, no âmbito do projeto da exposição "Estufa da Caatinga Mineira”, folders, guias e materiais para alunos e professores. Não havia no projeto da exposição "Estufa do Cerrado" a previsão de desenvolvimento de materiais educativos, ainda que, conforme tenham afirmado dois dos conceptores de conteúdo (CER1 e CER2), fosse intenção ter esses recursos. A ideia desses conceptores era de que os materiais fossem produzidos pelas equipes que atuam na educação ambiental no Jardim Botânico de São Paulo.

Concluímos, pela análise realizada, que os discursos expositivos, no que se refere ao nível de exigência dos conteúdos relacionados à biodiversidade, considerando a heterogeneidade dos níveis de conhecimentos dos visitantes, podem contribuir para acessar conhecimentos relativamente mais complexos. Estes resultados vão assim de encontro com a proposta de Young (2007), que é permitir o acesso a conhecimentos que possibilitem obter informações confiáveis e outras visões para a reflexão sobre o mundo.

Por fim, destacamos que a adoção de uma metodologia mista, embasada por uma teoria da área curricular com forte aporte sociológico, possui ampla potencialidade para a análise dos processos educacionais em museus. Os 
resultados dessa investigação e de outras que também utilizaram a teoria de Basil Bernstein (MARTINS, 2011; MARANDINO, 2001, 2014), permitiram identificar as especificidades dos processos de recontextualização dos discursos pedagógicos dos museus, tais como a diversidade de agências e agentes que compõem os campos de recontextualização, as diferentes formas de financiamento das ações educativas e a fraca regulação da educação em museus. Por meio da análise realizada nesta investigação, que incluiu um tratamento quantitativo dos dados, foi possível compreender também as especificidades dos discursos expositivos, explicitando como o posicionamento dos agentes e agências influenciaram nas mensagens presentes nas exposições.

Em um cenário de ampliação do papel educativo dos museus e frente à atual discussão de uma política própria da área, considerando ainda a função social dessas instituições na transmissão da cultura e para o exercício da cidadania, reforçamos a importância da realização de estudos sociológicos dos processos e práticas da educação em museus. 


\section{Bibliografia}

ACHIAM, M.; MARANDINO, M. A framework for understanding the conditions of science representation and dissemination in museums. Museum Management and Curatorship, v.29, n.1, p. 66-82, 2014.

ADEY, P., ROBERTSON, A., e VENVILLE, G. Effects of a cognitive acceleration programme on Year 1 pupils. British Journal of Educational Psychology, v.72, p.1-25, 2002.

AFONSO, A. J. Estado, mercado, comunidade e avaliação: Esboço para uma rearticulação crítica. Educação \& Sociedade, ano XX, n. 69, p. 139-164, dez. 1999.

ALLARD, M.; BOUCHER, S. Le musée et l'école. Québec: Hurtubise HMH, 1991. 136p.

; LEFEBVRE, B. Le musée, un lieu éducatif. Montréal: Musée d'Art Contemporain de Montréal, 1995. 416p.

ALMEIDA, G. S. B. ; HERENCIA, J. L. A Fundação Vitae e seu legado para a cultura brasileira - Parte I: fontes conceituais, linhas diretivas, programas próprios e legado.. In: III Seminário Internacional Políticas Culturais, 2012, Rio de Janeiro. Anais do Seminário Internacional Políticas Culturais. Rio de Janeiro: Fundação casa de Rui Barbosa, 2012.

ALVES, V. \& MORAIS, A. M. A Sociological analysis of Science curriculum and pedagogic praticies. Pedagogies: An International Journal, v.7, n.1, p. 52-71, 2013.

ANDRADE, I. R. Educação para conservação da CAATINGA no jardim botânico da Fundação Zoo-botânica de Belo Horizonte. Projeto submetido ao Prêmio para Projetos Educacionais - Modelos nos Jardins Botânicos Brasileiros "Educação para Conservação de espécies Nativas" HSBC, BGCI, Earthwatch e WWF. Fundação Zoo-botânica de Belo Horizonte, 2002.

. Projeto Educação para Conservação da Caatinga no Jardim Botânico" Recursos do Programa "Investing in Nature. Relatório Final. Fundação Zoo-Botânica de Belo Horizonte (FZB-BH) Sociedade de Amigos da Fundação Zoo-Botânica de Belo Horizonte. Belo Horizonte, 2004.

ANTUNES, C. Como desenvolver competências em sala de aula. Ed. Vozes. Petrópolis, 2001. 87p.

APPLE, M. W. Ideologia e currículo. 3a ed. Porto Alegre: Artmed, 2006. 288p. 
ARON, P. Class advantage : social class and knowledge production in Elementary classrooms under the new accountability. PhD Thesis. Faculty of the Graduate School of the University of Maryland, College Park, 2005. 346p.

ARNOT, M. Sociologia da Pedagogia de Basil Bernstein. Diálogos femininos e elaborações feministas. Educação, Sociedade \& Culturas, n. 19, p. 7-48, 2003.

ASENSIO, M. Nuevos escenarios para la interpretación del Patrimônio: el desarrollo de programas públicos. In: Dominguez et al. (Editores). El museo: un espacio para el aprendizaje. Huelva: Universidad de Huelva, p.47-77, 1999.

ATKINSON, P; DAVIES, S.; DELAMONT, S. Discourse and Reproduction: essays in honor of Basil Bernstein. Cresskill, N.J.: Hampton Press, 1995. 320p.

BARBOSA, 2013 . Uma Breve História do Programa de Pesquisas Ecológicas de Longa Duração (PELD-CNPq) do Brasil: da Semente ao Fruto In: Marcelo Tabarelli... [et al.]. PELD - CNPq : dez anos do Programa de Pesquisas Ecológicas de Longa Duração do Brasil : achados, lições e perspectivas. Recife : Ed. Universitária da UFPE, 2013. 446 p.

BARONGI, R., FISKEN, F. A., PARKER, M. \& GUSSET, M. (eds). Committing to Conservation: The World Zoo and Aquarium Conservation Strategy. Gland: WAZA Executive Office, 2015. 69 p.

BARRETO, E. S. S. Tendencias recentes do currículo no ensino fundamental no Brasil. In: Os currículos do ensino fundamental para as escolas brasileiras. Campinas: Autores asociados, 1998. 279p.

BELAËN, F. L'analyse de l'apparition d'un nouveau genre culturel dans les musées des sciences: les expositions d'immersion [Analysis of the appearance of a new cultural genre in science museums: immersion exhibitions]. Paper presented at the: International Cultural Heritage Informatics Meeting. Paris. September 2003.

BERNSTEIN, B. Poder, educacion y consciência. Sociología de la Transmisión Cultural. Barcelona: El Roure Editorial, 1990.164p.

A estruturação do discurso pedagógico. Classe, códigos e controle. Petrópolis: Vozes, 1996. 307p.

. Pedagogía, control simbólico e identidad: teoria, investigación y crítica. Madrid: Ediciones Morata, 1998. 240p.

Vertical and horizontal discourse: An essay. British Journal of Sociology os education, v.20, n.2, p.157-173, 1999.

Pedagogy, symbolic control and identity: Theory, research, critique (rev ed.). Londres: Rowman \& Littlefield. 2000. 229p. 
.; SOLOMON, J. Pedagogy, identity and the construction of a theory of symbolic control': Basil Bernstein questioned by Joseph Solomon. British journal of sociology of education, v. 20, n. 2, p. 265-279, 1999.

BGCI, 2017 - Investing in Nature - a Partnership between HSBC and BGCI. Disponível em: <https://www.bgci.org/worldwide/1823/>. Acesso em: 27 mar. 2017.

BITG00D, S. The Role of simulated immersion in exhibition, Technical Report, n. 90-20. Jacksonville, AL: Center for Social Design, 1990.

BIZERRA, A. Atividade de aprendizagem em museus de ciências. Tese (Doutorado em Ensino de Ciências e Matemática). Universidade de São Paulo, São Paulo, 2009.

BLOOM, B. S. What we are learning about teaching and learning: a summary of recente research. Principal, v. 66, n. 2, p. 6-10, 1986.

BORUN, M. et al. Planets and pulleys: studies of class visits to sciences museums. Philadelphia: Franklin Institute, 1983. 149p.

BOTELHO, A. Museus interactivos e desenvolvimento científico - Estudo sociológico de desempenhos e aprendizagens dos alunos. Tese de Mestrado em Educação (Ciências), Faculdade de Ciências da Universidade de Lisboa, 2001.

e MORAIS, A. M. O que fazem os alunos num centro de ciência: Uma análise das interacções com módulos científicos participativos. Revista Portuguesa de Educação, v. 16, n.1, p. 157-192, 2003.

e MORAIS, A. M. A aprendizagem de conceitos científicos em centros de ciência: Um estudo sobre a interacção entre alunos e módulos científicos participativos. Revista de Educação, v. XII, n. 1, p. 5-23, 2004.

BOURDIEU, P. Escritos de Educação. Introdução e organização de NOGUEIRA, Maria Alice; CATANI, Afrânio. Rio de Janeiro: Vozes, 2005, 7ạ ed., p. 229-237.

e DARBEL, A. 0 amor pela arte: os museus de arte na Europa e seu público. Trad. Guilherme João de Freitas Ferreira. São Paulo: Editora da Universidade de São Paulo: Zouk, 2003, 243 p.

BRANDÃO, C. R. F. Processo museológico: critérios de exclusão. O caso dos museus de História Natural. In: Semana de Museus da Universidade de São Paulo, 1999, São Paulo. Anais da Semana de Museus da Universidade de São Paulo. São Paulo: USP/ Pró-Reitoria de Cultura e Extensão Universitária, 1999, p.47-58.

BRASIL, 1988. Constituição da República Federativa do Brasil (1988). Constituição da República Federativa do Brasil. Brasília, DF: Senado, 1988.

BRASIL, 1999. Lei № 9795 de 1999 - Lei de Educação Ambiental - "Dispõe sobre 
a educação ambiental, institui a Política Nacional de Educação Ambiental e dá outras providências". Diário Oficial da União, Brasília, DF, 28 abr. 1999.

BRASIL 2000a. Lei Federal 9985, de 18 de julho de 2000. Regulamenta o art. 225, $\S 1$ o, incisos I, II, III e VII da Constituição Federal, institui o Sistema Nacional de Unidades de Conservação da Natureza e dá outras providências. Diário Oficial da União, Brasília, DF, 19 de jul. 2000.

BRASIL, 2000b. Parâmetros Curriculares Nacionais. Meio Ambiente: Saúde. Secretaria de Educação Fundamental. 2.ed. Rio de Janeiro: DP\&A, 2000.

BRASIL, 2002a. Decreto no. 4.339. Institui princípios e diretrizes para a implementação da Política Nacional da Biodiversidade. Diário Oficial da União, Brasília, DF, 23 ago. 2002.

BRASIL, 2002b Decreto no. 4.340. Regulamenta artigos da Lei no 9.985, de 18 de julho de 2000, que dispõe sobre o Sistema Nacional de Unidades de Conservação da Natureza - SNUC, e dá outras providências. Diário Oficial da União, Brasília, DF, 23 ago. 2002.

BRASIL, 2003. Decreto no. 4.703 de 21 de maio de 2003. Dispõe sobre o Programa Nacional de Diversidade Biológica - PRONABIO e a Comissão Nacional da Biodiversidade, e da outras providências. Diário Oficial da União, Brasília, DF, 21 maio 2003.

BRASIL, 2005. Decreto no. 5.577, de 8 de novembro de 2005. Institui, no âmbito do Ministério do Meio Ambiente, o Programa Nacional de Conservação e Uso Sustentável do Bioma Cerrado - Programa Cerrado Sustentável, e dá outras providências. Diário Oficial da União, Brasília, DF, 8 nov. 2005

BRASIL, 2009 Lei no. 11.904, de 14 de janeiro de 2009. Institui o Estatuto de Museus e dá outras providências. Diário Oficial da União, Brasília, DF, 14 jan. 2009.

BRASIL, 2012. Ministério do Meio Ambiente. Secretaria de Articulação Institucional e Cidadania Ambiental. 0 que o brasileiro pensa do meio ambiente e do consumo sustentável: Pesquisa nacional de opinião. Principais resultados. Rio de Janeiro: Overview, 2012. 82 p.

BRUNO, M. C. O. Museologia para professores: os caminhos da educação pelo patrimônio. São Paulo: Centro Estadual de Educação Tecnológica Paula Souza, 1998.

BUENO, J. P. de P. Objetos que ensinam em museus: análise do diorama do Museu de Zoologia da USP na perspectiva da praxeologia. 2015. Dissertação (Mestrado em Ensino de Biologia) - Ensino de Ciências (Física, Química e Biologia), Universidade de São Paulo, São Paulo, 2015. 
BUIJS, A. E.; FISCHER, A.; RINK, D.; YOUNG, J. Looking beyond superficial knowledge gaps: Understanding public representations of biodiversity. International Journal of Biodiversity Science and Management, v.4 n. 2, p. 65-80. 2008.

CALADO S.; NEVES, I. P. Currículo e manuais escolares em contextos de flexibilidade curricular: Estudo dos processos de recontextualização. Revista Portuguesa de Educação, v.25, n. 2, p.53-93, 2012.

.; NEVES, I. P.; MORAIS, A. M. Conceptual demando f Science curricula: A study at level of middle school. Pedagogies: An International Journal. V.8, n.3, p. 255-277, 2013.

CANTU, L. L. AND HERRON, J. D. Concrete and formal piagetian stages and science concept attainment. Journal of Research in Science Teaching. v.15 p. 135143. 1978.

CARDIM, R. USP destrói raro Cerrado em São Paulo onde seria construído "Museu Vivo". Espécies nativas e material genético únicos na cidade foram perdidos. 30 de maio de 2014. Disponível em: <http://ciclovivo.com.br/noticia/usp-destroi-raro-cerrado-em-sao-paulo-quehavia-sido-prometido-museu-vivo-em-2011/> Acesso em 30 mar. 2017.

CARDOSO, I. PPBio no Semi-árido. Meio ambiente Brasil, 2009. Disponível em: $<$ https://sites.google.com/site/aabrasilma/Home/planos-de-

acao/pdctbrasil/pdctoutros/p-d-t-i-do/ppbionosemi-arido> Acesso em 23 mar 2017.

CAZELLI, S. Alfabetização científica e os museus interativos de ciência. Dissertação (Mestrado) - Pontifícia Universidade Católica do Rio de Janeiro, 1992.

Divulgação Científica em espaços não formais. In Anais do XXIV Congresso da Sociedade de Zoológico do Brasil, p. 10-20, Belo Horizonte, 2000.

. MARANDINO, M.; STUDART, D. Educação e Comunicação em museus de ciência: aspectos históricos, pesquisa e prática. In: GOUVÊA, Guaracira et al. (orgs.). Educação e Museu. A construção social do caráter educativo dos museus de ciências. Rio de Janeiro: Acces, 2003, p. 83-106.

CHAGAS, M. Memória e poder: contribuição para a teoria e a prática nos ecomuseus. Simpósio Museologia e Desenvolvimento Sustentável na América Latina e Caribe. ICOFOM LAM, Santa Cruz, RJ, Subcomitê Regional para a América Latina e Caribe/ICOFOM LAM: 12-17. 2000

CNE, 2012. Resolução CNE/CP no. 2. Estabelece as Diretrizes Curriculares Nacionais para a Educação Ambiental. Diário Oficial da União, Brasília, DF, 15jun. 2012. 
CONAMA, 2003. Resolução CONAMA no. 339. Dispõe sobre a criação, normatização e o funcionamento dos jardins botânicos, e dá outra providências. Diário Oficial da União, Brasília, DF, 03 nov. 2003.

CONAMA, 2006 Resolução no. 371 Revoga a Resolução no 2/96 Estabelece diretrizes aos órgãos ambientais para o cálculo, cobrança, aplicação, aprovação e controle de gastos de recursos advindos de compensação ambiental, conforme a Lei no 9.985, de 18 de julho de 2000, que institui o Sistema Nacional de Unidades de Conservação da Natureza-SNUC e dá outras providências. Diário Oficial da União, Brasília, DF, 6 abr. 2006.

COSTA, M. V. Poder, discurso e política cultural: constribuições dos Estudos Culturais ao campo do currículo. In: LOPES, A. C. e MACEDO, E. (orgs.) Currículo: debates contemporâneos. São Paulo: Cortez, 2002. p. 133-149.

CRESWELL, J. W. Projeto de pesquisa: métodos qualitativo, quantitativo e misto. Porto Alegre: Artmed, 2007. 248p.

., \& PLANO CLARK, V. Designing and Conducting Mixed Methods Research. Thousand Oaks, CA, 2007.488p.

CRUZ, W. P. S. Educação e conservação da biodiversidade no contexto escolar da Reserva Extrativista Terra Grande Pracúba. Dissertação (Mestrado) - Universidade Federal do Pará, Instituto de Ciências da Educação, Programa de Pós-Graduação em Educação, Belém, 2014.

DAMIANI, M. F. Discurso pedagógico e fracasso escolar. Ensaio: Avaliação e Políticas Públicas em Educação, Rio de Janeiro, v.14, n.53, p. 457-478, out./dez. 2006.

DASMANN, R. F. A Different Kind of Country. New York: MacMillan Company, 1968. 276p.

DAVALLON, J. Comunicação e sociedade: pensar a concepção da exposição. in: BENCHETRIT, Sarah Fassa; BEZERRA, R. Z. e MAGALHÃES, A. M. (org.). Museus e comunicação - exposições como objeto de estudo. Rio de Janeiro, Museu Histórico Nacional, 2010, pg. 21-34.

DAVALLON, J., GRANDMONT, G. \& SCHIELLE, B. L'environnement entre au Musée. Collection Muséologies. Lyon: Presses Universitaires de Lyon, 1992. 208p.

DAVIES, B. Introdução. In: MORAIS, A.M., NEVES, I. P. DAVIES, B. E DANIELS, H. (eds.), Towards a sociology of pedagogy: The contribution of Basil Bernstein to research. Nova Iorque: Peter Lang, 2001.

DEAN, D. Museum Exhibition: theory and practice. New York: Routledge, 1994. 177p. 
DELAMONT, S. The anomalous beasts: hooligans and the sociology of education. Sociology, v. 34, n. 1, p. 95-111, 2000.

DESCOLA, P. Ecologia e Cosmologia. In: CASTRO, E. \& PINTON, F. (orgs.) Faces do Trópico Úmido: conceitos e questões sobre desenvolvimento e meio ambiente. Belém: Ed. Cejup/UFPA/NAEA, , 1997, p. 243-261.

DESVALLÉS, A. A few problems raised by the identity definition and the way the museum deals with the theorethical and practical questions raised by it. In: SOFKA, Vinos (Coord.). Symposium Museology and Identity. Basic papers: mémoires de base. Stockholm: International Committee for Museology: Museum of National Antiquities, p. 73-77, 1986.

DRISCOLL, M. Psychology of learning for instruction. Needhan Heights: Allyn \& Bacon, p. 476, 2000. 472p.

DUSSEL, I. A transmissão cultural assediada: metamorfoses da cultura comum na escola. Cadernos de Pesquisa, v.39, n.137, p.351-365, 2009.

EGLER, I. Biodiversidade, Ciência e Tecnologia. Revista CEJ, v. 3, n. 8, 1999.

FALK, J. Free-Choice Science Learning: Framing the Discussion. In FALK, J. FreeChoice Science Education - How We Learn Science Outside of School. Teachers College Press, Nova York, 2001. Cap.1.

; STORKSDIECK, M. Learning science from museums. História, ciências, saúde: Manguinhos, v.12. Rio de Janeiro: Fundação Casa de Oswaldo Cruz, p.117144, 2005.

FERREIRA, S., MORAIS, A. M. \& NEVES, I. P. Science curricula design. Analysis of authors' ideological and pedagogical principles. International Studies in Sociology of Education, v. 21, n. 2, p. 137-159, 2011.

.; MORAIS, A. M. The nature of science in science curricula: Methods and concepts of analysis. International Journal of Science Education, v.35, n.16, p. 2670-2691, 2013.

FISCHER, A.; YOUNG, J. Understanding mental constructs of biodiversity: Implications for biodiversity management and conservation. Biological Conservation, v.136, n. 2, p. 271-282, 2007.

FORTIN-DEBART, C. Le Musée de Sciences Naturelles, un partenaire de l'école pour une education relative a l'environnement :du message scientifique au débat de société. In: ERE, Nature et Culture: Art et science au service de l'éducation relative à l'environnement. In: GIRARD, M. e DUCHEMIN, R. (dirs.), Vertigo, la revue électronique en sciences de lenvironnement. Montréal: Université du Québec à Montréal, v. 4, n.2, 2003. 
FORQUIN, J. C. Esola e Cultura. Bases Sociais e epistemologicas do conhecimento escolar. Porto Alegre: Artmed, 1993. 208p.

FZB-BH. Homepage: Institucional. Disponível em: <http://portalpbh.pbh.gov.br/pbh/ecp/comunidade.do?evento=portlet\&pIdPlc= ecpTaxonomiaMenuPortal\&app=fundacaobotanica\&tax=6770\&lang=pt_BR\&pg= 5522\&taxp=0\&> Acesso em: 15 mar. 2017.

GALIAN, C. V. A. A recontextualização e o nível de exigência conceitual do conhecimento escolar. Educação e Pesquisa, v. 37, p. 763-778, 2011.

.; LOUZANO, P. B. J. Michael Young e o campo do currículo: da ênfase no "conhecimento dos poderosos" à defesa do "conhecimento poderoso". In: Educação e Pesquisa, São Paulo, v. 40, n. 4, p. 1109-1124, out./dez., 2014.

GASTON, K.J. What is biodiversity? In: Biodiversity: A Biology of Numbers and Difference (ed. K.J. Gaston). Blackwell Science, Oxford, 1996. p. 1-9

GIL-PÉREZ, D.; VILCHES, A. e GONZÁLEZ, M. Otro mundo es posible: de la emergencia planetaria a la sociedad sostenible. Didáctica delas ciencias experimentales y sociale, n. 16, p. 57-81, 2002.

GÓMEZ, G. C. e ARIZA, M. C. R. Investigación en museografía de espacios arqueológicos. In: CARDONA, F. X. H. E ARIZA, M. C. R. (coords.) Museografía Didáctica e Interpretación de espacios arqueológicos. Ediciones Trea, 2012. P. 59-80.

GÓMEZ-POMPA, A. \& KAUS, A. Domesticando o Mito da Natureza Selvagem. In: DIEGUES, A. C. S. (org.) Etnoconservação: novos rumos para a conservação da natureza, São Paulo: Hucitec/Annablume/Nupaub-USP, 2000. p. 125-148.

GOHN, Maria da Glória. Educação não-formal, participação da sociedade civil e estruturas colegiadas nas escolas. Ensaio: Avaliação e Políticas Públicas em Educação, vol. 4, n. 50, 2006.

GONZÁLEZ, M.; GIL-PÉREZ, D.; VILCHES, A. La atención a los problemas del planeta en las grandes exposiciones internacionales. Enseñanza de las ciencias, Número Extra VI Congreso, p. 75-76, 2001.

GOODSON, I. F. Currículo: teoria e história. Petrópolis, RJ: Vozes, 1995. 144p.

HARAWAY, D. J. The Promises of Monsters: A Regenerative Politics for Inappropriate/ d Others. In: Grossberg, L., Nelson, C. and Treichler, P. A. (orgs) Cultural Studies. New York: Routledge, 1992, p. 295-337.

HARRISON, I.; LAVERTY, M. E STERLING, E. Definition of biodiversity. Disponível em: http://cnx.org/content/m12151/1.2/, 2004. Acesso em: 15 jul. 2015. 
HEIN, G. What can Museum Educators learn from construtivist theory? Study Series. CECA/ICOM, p.3-5, 1996.

; ALEXANDER, M. Museums. Places of learning. Washington D.C.: AAM/Edcom, 1998. 57p.

HOEHNE, F.C. Relatório anual do Departamento de Botânica: exercício de 1939. Secretaria da Agricultura, Indústria e Comércio, São Paulo, 1940.

HOOPER-GREENHILL, E. Education, communication and interpretation: towards a critical pedagogy in museums. In: The educational role of the museum. London: Routledge, ,1994a, p. 3-25.

Museum learners as active postmodernists: contextualizing constructivism. In: The Educational role of The Museum. Routledge, London, 1994b, p., 67-72.

IBRAM. Museus em números volume 1. Brasília: IBRAM, 2011. 240p.

INSA, 2017. O SIGSAB. Disponível em: <http://sigsab.insa.gov.br/sobre> Acesso em: 23 abr. 2017.

JBSP, 2017. Homepage: Institucional - Missões. Disponível em <http://jardimbotanico.sp.gov.br/o-jardim/missao/> Acesso em 23 abr. 2017.

JEFFS, T.; SMITH, M. K. Using Informal Education, Buckingham: Open University Press. 1990.

JOHNSON, R. B., \& ONWUEGBUZIE, A. J. Mixed Methods Research: A Research Paradigm Whose Time Has Come. Educational Researcher, v.33, n.7, p. 14-26, 2004.

JOLY, C. A. ; HADDAD, C. F. B.; VERDADE, L. M.; OLIVEIRA, M. C.; BOLZANI, V. S. Science Plan \& Strategies for the next decade. São Paulo: Fapesp, 2009

KALTENBORN, B. P.; GUNDERSEN, V.; STANGE, E.; HAGEN, D.; SKOGEN, K. Public perceptions of biodiversity in Norway: From recognition to stewardship? Norsk Geografisk Tidsskrift - Norwegian Journal of Geography v. 70 , n. 1, 2016.

KAPLAN, F. E. S. Exhibitions as communicative media. In: HOOPER-GREENHILL, Eilean. Museum, media, message. Routledge, London, 1995. P. 37-58.

KAWASAKI, C. S. e OLIVEIRA, L.B. Biodiversidade e educação: as concepções de biodiversidade dos formadores de professores de biologia. In.: Atas do IV Encontro Nacional de Pesquisa em Educação em Ciências. Baurú, SP, 2003.

KELSEY, L. H. E. Learning about biodiversity: a first look at the theory and practice of biodiversity education, awareness and training in Canada. 
Working document. The Biodiversity Convention Office and Environment Canada, 1998.

KRESS, G; JEWITT, C.; TSATSARELIS, C. Knowledge, Identity, Pedagogy: Pedagogic Discourse and the Representational Environments of Education in Late Modernity. Linguistics and Education, v.11, n.1, p. 7-30, 2000.

KRATHWOHL, D. R. A revision of Bloom's taxonomy: an overview. Theory in Practice, v. 41, n. 4, p. 212-218, 2002.

LEITE, M. S. Recontextualização e transposição didática. Introdução à leitura de Basil Bernstein e Yves Chevallard. Araraquara: Junqueira \& Marin. 2007. 95p.

LERNER, L. C. Políticas públicas de implementação da convenção da diversidade biológica no Brasil: o caso do Baixo Juruá. Dissertação (Mestrado em Ciência Ambiental) - Ciência Ambiental, Universidade de São Paulo, São Paulo, 2008.

LEWINSOHN, T.M. \& PRADO, P.I. Biodiversidade brasileira: síntese do estado atual do conhecimento. Contexto, São Paulo. 2002. 110p.

LOOMIS, R. J. Museum visitor evaluation : new tool for management. English, Book, Illustrated edition: 1987.306p.

LOPES, A. C. e MACEDO, E. (orgs.) Currículo: debates contemporâneos. São Paulo: Cortez, 2002. 240p.

LOPES, A. C.; GOMES, M. M.; LIMA, I. S. Diferentes Contextos na Área de Ciências nos PCNs para o Ensino Médio: limites para a integração. Revista Contexto \& Educação. n.69 p. 45-67, 2013.

LOPES, M. M. O Brasil descobre a pesquisa científica: os museus e as ciências naturais no século XIX. São Paulo: Hucitec, 1997. 369p.

LUDE, A. The Spirit of Teaching ESD - Biodiversity in Educational Projects. In ULBRICH K, SETTELE J, BENEDICT FF (eds). Biodiversity in Education for Sustainable Development - Reflection on School-Research Cooperation. Pensoft Publishers, Sofia-Moscow, 2010. P. 17-30.

MACE, G. Whose conservation? Science, v. 345, n.6204, p. 1558-1560, 2014.

MAINARDES, J. Moving away from a graded system : a policy analysis of the Cycles of Learning Project (Brazil). Thesis (Doctor of Philosophy) - Institute of Education, University of London, London, 2004.

MAINARDES, J. \& STREMEL, S. A teoria de Basil Bernstein e algumas de suas contribuições para as pesquisas sobre políticas educacionais e curriculares. Revista Teias, proPEd/UERJ, v. 11, n. 22, 2010. 
MANTOVANI, W.; MONTEIRO, R; ANJOS, L.; CARIELlO, M. O. Pesquisas em unidades de conservação no domínio da caatinga: subsídios à gestão. Fortaleza: Edições UFC, 2017. 605p.

MARANDINO, M. O Conhecimento Biológico nas Exposições de Museus de Ciências: análise do processo de construção do discurso expositivo. Tese (doutorado) - Faculdade de Educação, Universidade de São Paulo (USP), São Paulo, 2001.

A biologia nos museus de ciências: a questão dos textos em bioexposições. Ciência e Educação (Bauru), v. 8, n. 2, p. 187-202, 2002.

The expositive discourse as pedagogical discourse: studying recontextualization in the production of a science museum exhibition. Cultural Studies of Science Education, v.10, 2014.

. Análise sociológica da didática museal: os sujeitos pedagógicos e a dinâmica de constituição do discurso expositivo. Educação e Pesquisa, v.41 n.3. São Paulo, 2015.

e DIAZ ROCHA, P. E. . La Biodiversidad en Exposiciones inmersivas de museos de ciencias: implicaciones para educación en museos. Enseñanza de las Ciencias, v. 29.2, p. 221-236, 2011

;) SELLES, S. E; FERREIRA, M. S. Ensino de biologia: histórias e práticas em diferentes espaços educativos. São Paulo: Cortez, 2009, 215 p.

; CAMPOS, N. F.; CAFFAGNI, C. W.; et al. A percepção de biodiversidade em visitantes de museus: um estudo no Brasil e na Dinamarca antes da visita. Tempo Brasileiro, Rio de Janeiro, n. ja/mar. 2012., p. 97-112, 2012.

; LAURINI, C. R.; SILVA, A. B. F; PRADO, F. A.; BRANCO, M. F.; UEZONO, P. Y. $O$ que o público adulto entende sobre biodiversidade durante visitas a museus de ciência? X Encontro Nacional de Pesquisa em Educação em Ciências - X ENPEC. Águas de Lindóia, 2015.

. ; SILVEIRA, R. V. M. ; CHELINI, M. J. e ; GARCIA, V. A. R. ; MARTINS, L. C. ; LOUREnÇO, M. F. ; Florentino, H. A. . A Educação Não Formal e a Divulgação Científica: o que pensa quem faz? In: IV Encontro Nacional de Pesquisa em Ensino de Ciências - ENPEC, 2004, Bauru. Atas do IV Encontro Nacional de Pesquisa em Ensino de Ciências - ENPEC, 2004.

.; SOUZA, M. P. C.; PUGLIESE, A. Como, o que e para quem se divulga a biodiversidade. Refletindo sobre as relações entre pesquisa, educação e divulgação científica. In: MANTOVANI, W.; MONTEIRO, R; ANJOS, L.; CARIELLO, M. O. Pesquisas em unidades de conservação no domínio da caatinga: subsídios à gestão. Fortaleza: Edições UFC, 2017. 
MARTINS, L. C. A constituição da educação em museus: o funcionamento do dispositivo pedagógico museal por meio de um estudo comparativo entre museus de artes plásticas, ciências humanas e ciência e tecnologia. Tese (doutorado) - Faculdade de Educação, Universidade de São Paulo (USP), São Paulo, 2011.

MARTINS, I. P. Literacia Científica e Contributos do Ensino Formal para a Compreensão Pública da Ciência. Lição Síntese apresentada para Provas de Agregação em Educação. Universidade de Aveiro. 2003.

MARTINS, I.; GOUVÊA, G.; PICCININI, C. Aprendendo com Imagens. Ciência e Cultura, v.57, n.4, 38-40, 2005.

MARZANO, R.J.; J.S. KENDALL, EDS. The New Taxonomy of Educational Objectives. 2 ed. Corwin Press: Thousand Oaks, California. 2007, 208p.

MAZZAROLO, L. A. Conceitos Básicos de Filogenética. Curso de graduação em biologia. Uenf, 2005, 24p.

MCT, 2005. Programa de Pesquisa em Biodiversidade - PPBio. Documento Básico. Brasília, 52p.

MCT, 2010. Plano de Ação em Ciência, Tecnologia e Inovação 2007-2010. Principais Resultados e Avanços. Ministério da Ciência e Tecnologia. Brasília, DF, 168 .

MCTIC, 2017a. Apresentação das linha IV - Ciência, Tecnologia e Inovação para Desenvolvimento Social das ações em CT\&I. Disponível em: <http://www.mct.gov.br/index.php/content/view/73413.html> Acesso em 09 mai. 2017.

MCTIC, 2017b. PELD - Programa de Pesquisa Ecológica de Longa Duração. Disponível em: <http://cnpq.br/apresentacao-peld> Acesso em: 15 nov. 2016.

MEDEIROS, R.; ARAÚJO, F. F. S. Dez anos do Sistema Nacional de Unidades de Conservação da Natureza: lições do passado, realizações presentes e perspectivas para o futuro. Brasília: MMA, 2011, 220 p.

MENZEL, S. \& BÖGEHOLZ, S. The Loss of Biodiversity: How do Students in Chile and Germany perceive resource dilemmas and what solutions do they see? Research in Science Education, v.39, n. 4, p. 429-447, 2009.

Values, Beliefs, and Norms that Foster Chilean and German Pupils' Commitment to Protect Biodiversity. International Journal of Environmental and Science Education,v. 5, n.1, p. 33-49, 2010.

MMA, 2011. Plano de Divulgação do Bioma Caatinga. Brasília: 2011. 9p. Disponível em: 
<http://www.meioambiente.gov.br/estruturas/203/_arquivos/plano__comunic ao_jorge_1_203_1.pdf> Acesso em 23 fev. 2017.

MMA, 2015. Mapeamento do uso e cobertura da terra do Cerrado. Projeto Terra Cerrado 2013. Ministério do Meio Ambiente; 1 ed. 67p. Brasília - DF. Disponível: <http://www.dpi.inpe.br/tccerrado/TCCerrado_2013.pdf>_Acesso em 23 fev. 2017.

MMA, 2017a. Homepage - Institucional. Disponível em: <http://www.mma.gov.br/o-ministerio/apresentacao> Acesso em 20 maio 2017.

MMA, 2017b. Homepage - Início. Disponível em: <http://www.mma.gov.br> Acesso em 20 maio 2017.

MMA, 2017c. Caatinga. Disponível em: <http://www.mma.gov.br/biomas/caatinga> Acesso em 20 maio 2017.

MMA/MEC, 2014. Por um Brasil Sustentável ProNEA, Marcos Legais \& Normativos . 4ed - Brasília: Ministério do Meio Ambiente/Ministério da Educação. 2014.

MOORE, R; MATON, K. Founding the sociology of knowledge: Basil Bernstein, intellectual fields and the epistemic device. Towards a sociology of pedagogy: The contribution of Basil Bernstein to research,, 2001, p. 153-82.

MORAIS, A. M. Influência do nível de exigência conceptual dos professores no sucesso dos alunos em Ciências: Um estudo sociológico. Revista de Educação, v.II, n. 1, p.62-80, 1991.

Basil Bernstein: Sociologia para a educação. In: TEODORO, A. e TORRES, C. (ed.), Educação crítica \& utopia - Perspectivas para o século XXI. Lisboa: Edições Afrontamento, 2004.

e NEVES, I. P. Pedagogic social contexts: Studies for a sociology of learning. In A. Morais, I. Neves, B. Davies \& H. Daniels (Eds.), Towards a sociology of pedagogy: The contribution of Basil Bernstein to research (Cap. 8). Nova Iorque: Peter Lang, 2001.

e NEVES, I. P. Processos de intervenção e análise em contextos pedagógicos. Educação, Sociedades e Culturas, v.19, p. 49-87, 2003.

e NEVES, I. P. Fazer uma investigação usando uma abordagem metodológica mista. Revista Portuguesa de Educação. v.20, n. 2, p. 75-104, 2007a.

e NEVES, I. P. A teoria de Basil Bernstein. Alguns aspectos fundamentais. Revista Praxis Educativa, v. 2, n. 2, p. 115-130, 2007b. 
e NEVES, I. P. Textos e contextos educativos que promovem aprendizagem. Optimização de um modelo de prática pedagógica. Revista Portuguesa de Educação, v.22, n. 1, p. 5-28, 2009.

e NEVES, I. P. Educational texts and contexts that work: Discussing the optimization of a model of pedagogic practice. In: D.Frandji \& P. Vitale (Ed.), Knowledge, pedagogy \& society: International perspectives on Basil Bernstein`s sociology of education. Londres: Routledge, 2011.

e NEVES, I. P. Estruturas de conhecimento e exigência conceitual na educação em ciências. Educação, Sociedade \& Culturas. V. 37, p.63-88, 2012.

; NEVES, I. P.; FERREIRA, S. Currículos, Manuais Escolares e Práticas Pedagógicas: estudo de processos de estabilidade e mudança no sistema educativo. Edições Sílabo, Lisboa, 2014. 358p.

MOREIRA, A. F. Currículo, utopia e pós-modernidade. In: Currículo: Questões atuais. Campinas, SP: Papirus, p.9-28, 2000, p. 65-80.

e SILVA, T. T. (orgs.). Currículo, cultura e sociedade. São Paulo: Cortez, 1995. 154p.

MORTENSEN, M. F. Exhibit Engineering: A new research perspective. Doctoral Dissertation. Department of Science Education University of Copenhagen. 2010.

MOSS, G. Informal Literacies and Pedagogic Discourse. Linguistics and Education. V. 11, no.1, p. 47-64, 2000

MOTOKANE, T. M; KAWASAKI, S. C; OLIVEIRA, B. L. Por que a Biodiversidade pode ser um tema para o Ensino de Ciências? In: MARANDINO, M. et. al. Olhares sobre os diferentes contextos da biodiversidade. FEUSP: São Paulo, 2010, p. 30-60.

NAVAS, A. M. Concepções de popularização da ciência e da tecnologia no discurso político: impactos nos museus de ciências. Dissertação (Mestrado) Faculdade de Educação, Universidade de São Paulo, São Paulo, 2008.

NEVES, I. P., MORAIS, A. M., MEDEIROS, A., \& PENEDA, D. Os discursos instrucional e regulador em programas de ciências: Estudo comparativo de duas reformas. Revista Portuguesa de Educação, v. 13, n. 1, p. 209-245, 2000.

NOSS, R. Indicators for monitoring biodiversity: A hierarchical approach. Conservation Biology, v.4, p. 355 - 364, 1990.

OLIVEIRA, D. Biodiversidade em políticas públicas de ciência, tecnologia e inovação: caracterização e perspectivas na integração do fomento à divulgação e educação em ciências. Tese (doutorado) - Universidade Federal do Rio Grande - 
FURG, Faculdade de Educação, Programa de Pós Graduação em Educação em Ciências: Química da Vida e Saúde, 2016.

OLIVEIRA, A. D. Biodiversidade e museus de ciências: um estudo sobre transposição museográfica nos dioramas. Dissertação (mestrado). São Paulo: Interunidades Ensino de Ciências, USP, 2010.

e MARANDINO, M. A Biodiversidade no Saber Sábio: investigando concepções de biodiversidade na literatura e entre pesquisadores. Revista de Educação, Ciências e Matemática, v.1, n.1, p. 51-66, 2011.

e MARANDINO, M. Dioramas e biodiversidade: estudando um museu de ciências brasileiro. Educacion y Futuro: revista de investigacion aplicada y experiencias educativas, v.27, p. 107-120, 2012.

OVIGLI, D. F. B. As pesquisas sobre educação em museus e centros de ciências no Brasil: estudo descritivo e analítico da produção acadêmica. 2013. 376 f. Tese (doutorado) - Universidade Estadual Paulista Júlio de Mesquita Filho, Faculdade de Ciências de Bauru, 2013.

PASCUAL, U., BALVANERA, P., DÍAZ, S., PATAKI, G., ROTH, E., STENSEKE, M., WATSON, R.T., BAŞAK DESSANE, E., ISLAR, M., KELEMEN, E., MARIS, V., QUAAS, M., SUBRAMANIAN, S.M., WITTMER, H., ADLAN, A., AHN, S., ALHAFEDH, Y.S., AMANKWAH, E., ASAH, S.T., BERRY, P., BILGIN, A., BRESLOW, S.J., BULLOCK, C., CÁCERES, D., Valuing nature's contributions to people: the IPBES approach(Review). Current Opinion in Environmental Sustainability. Volume 26-27, p 7-16, 2017.

PAULO, C. M. As políticas de biodiversidade e de mudanças climáticas: (des) articulações e reflexos sobre o mosaico de conservação do Cristalino/ MT. Tese (Doutorado em Ciência Ambiental) - Instituto de Energia e Ambiente, Universidade de São Paulo, São Paulo, 2016.

PEDRETTI, E. G. Perspectives on Learning Through Research on Critical IssuesBased Science Center Exhibitions. Science Education, v.88 (Suppl. 1), p. 34-47, 2004.

PEREIRA, T S ; COSTA, M L. N. Os Jardins Botânicos brasileiros - desafios e potencialidades. Ciência e Cultura, v.62, n.1, São Paulo, 2010.

PORCEDDA, A., LANDRY, J. LEPAGE, L. Musées de sciences et développement durable: militantisme ou changement de paradigme?, en Emond, A. (org). L'éducation muséale vue du Canada, des Etats-Unis et d'Europe: recherché sur les programmes et les expositions. Editions Multimondes. Montreal, 2006, p. 279-292.

PRIMI, R. et al . Competências e habilidades cognitivas: diferentes definições dos mesmos construtos. Psic.: Teor. e Pesq., Brasília, v. 17, n. 2, p. 151-159, Aug. 2001

Disponível

em: 
<http://www.scielo.br/scielo.php?script=sci_arttext\&pid=S0102-

$37722001000200007 \& \operatorname{lng}=e n \& n r m=i s o>$. Acesso em: 10 Jun. 2017.

PUGLIESE, A. Os museus de ciências e os cursos de licenciatura em ciências biológicas: o papel desses espaços na formação inicial de professores. Tese (Doutorado em Educação) - Faculdade de Educação, Universidade de São Paulo, São Paulo, 2015.

ROCHA, Y. T. E CAVALHEIRO, F. Aspectos históricos do Jardim Botânico de São Paulo. Rev. bras. Bot. v.24, n.4, suppl.0, São Paulo, 2001.

ROQUE, M. I. R. Comunicação no museu. in: BENCHETRIT, S.F.; BEZERRA, R. Z. e MAGALHÃES, A. M. (org.) Museus e comunicação - exposições como objeto de estudo. Rio de Janeiro, Museu Histórico Nacional, 2010, p. 48-65.

SADOVNIK, A.R. Basil Bernstein (1924-2000). Perspectivas: revista trimestral de educación comparada, Paris, v.XXXI, n.4, p.687-703, 2001. Disponível em:http://www.ibe.unesco.org/fileadmin/user_upload/archive/publications/Th inkersPdf/bernsteine.pdf. Acesso em: 08 ago. 2015.

. Toward a sociology of educational change: an application of Bernstein to the US. No Child Left Behind Act. In: MOORE, R.; ARNOT, M.; BECK, J.; DANIELS, $\mathrm{H}$. Knowledge, power and educational reform: applying the sociology of Basil Bernstein. London: Routledge, 2006, p. 196-210.

SAMPAIO E SOUSA, A.; FERREIRA, A. J.; CARVALHO, P. S. ; PAIVA, J. Ensino Experimental das Ciências. Um Guia para Professores do Ensino Secundário. Física e Química. Universidade do Porto Edições, 2012, 273p.

SANDELL, R. Means to an End: Museums and the combating of social inequality . In: SEMEDO, A. et al. A cultura em ação - impactos sociais e território. Porto: Edições Afrontamento, 2003, p. 63-67.

SANTOS, M. C. Repensando a Ação Cultural e Educativa dos Museus. Salvador: Centro Editorial e Didático da UFBA, 1993, 135p.

SANTOS, L. L. de C. P. Bernstein e o campo educacional: relevância, influências e incompreensões. Cadernos de Pesquisa , São Paulo, n. 120, p. 15-49, nov. 2003.

SANTOS, B. S.; MENESES, M. P. G.; NUNES, J. A. Para ampliar o cânone da ciência: a diversidade epistemológica do mundo. In: SANTOS, B. S. (org.). Semear outras soluções: Os caminhos da biodiversidade e dos conhecimentos rivais. Rio de Janeiro: 2005.

SANTOS, A. P. S.; CUNHA, A. R. B. A.; DENIS, A. A. C.; PEREZ-MARIN, A. M (orgs.) Vivências e práticas para a coabitação no Semiárido: ensaios e reflexões. Ed.: Instituto Nacional do Semiárido. Campina Grande, 2016, 206p. 
SARKAR, Sahotra. Defining "Biodiversity”, Assessing Biodiversity. The Monist, v. 85, n. 1, p. 131-155, 2002.

SCHWARCZ, L. K. M. O nascimento dos museus brasileiros 1870-1910. In: História das Ciências Sociais no Brasil. São Paulo: IDESP/ Vértice/ FINEP, p.20-7, 1989, 576p.

SENA, E.. Secretaria do Verde decreta criação de reserva de cerrado no Butantã. Diário Oficial de São Paulo (DOC), v. 55, n.122, 2010.

SENE, J. E. A sociedade do conhecimento e as reformas educacionais. Diez años de cambios en el Mundo, en la Geografía y en las Ciencias Sociales, 1999-2008. Actas del X Coloquio Internacional de Geocrítica, Universidad de Barcelona, 26-30 de maio de 2008. Disponível em: <http://www.ub.es/geocrit/xcol/91.htm>

SHAMOS, M. The myth of scientific literacy. New Brunswick, New Jersey: Rutgers University Press, 1995. 261p.

SHAYER, M.; ADEY, P.S. Towards a science of science teaching. London, Heinemann, 1981.

SILVA, P; MORAIS, A. M.; NEVES, I. P. O currículo de ciências no 10 ciclo do ensino básico: estudo de (des)continuidades na mensagem pedagógica. Revista Portuguesa De Educação, v.26, n. 1, p. 179-217, 2013b.

Materiais curriculare, práticas e aprendizagens: estudo no contexto das ciências do 10 ciclo do ensino básico. Revista Práxis Educativa,v. 8, n. 1, p. 133-172, 2013.

SILVA, S. D.; LOUREIRO, J. M. M. XIV Gênese e Singularidades nos Processos Curatoriais nos Espaços de História Natural: dos Gabinetes aos Museus como espaços discursivos da ciência e da "Ideia de Nação". Anais do Encontro Nacional de Pesquisa em Ciência da Informação - ENANCIB, 2013.

SILVA, T. T. 0 currículo como fetiche: a poética e a política do texto curricular. Belo Horizonte: Autêntica, 1999, 117p.

Documentos de identidade: uma introdução às teorias do currículo. Belo Horizonte: Autêntica, 2002. 156p.

SMITH, M. K. Non Formal Education. 2001 Disponível em: <http://infed.org/mobi/what-is-non-formal-education/> Acessado em 05 ago. 2013.

SMITH, S.C. Classroom Interaction and Pedagogic Practice: A Bernsteinian Analysis. International Journal of Sociology of Education, v.2, n. 3, p.2013, 263-291. doi: 10.4471/rise.2013.34 
SOULÉ, M. E. \& WILCOX, B. A. (eds.). Conservation Biology: An evolutionaryecological perspective. Massachusetts: Sinauer, 1980, 395p.

SOUZA, M. P. C. 0 papel educativo dos jardins botânicos: análise das ações educativas do Jardim Botânico do Rio de Janeiro. 2009. Dissertação (Mestrado em Educação) - Faculdade de Educação, Universidade de São Paulo, São Paulo, 2009.

.; MARANDINO, M. . Jardim Botânico e Público: trajetórias educacionais. In: SElles, S. E. ; CASSAB, M.. (Org.). Currículo, Docência \& Cultura. 1ed.Niteroi: EDUFF, 2012, v. 1, p. 303-330.

SPEGLICH, E. Duração: entre imagens do Programa Biota. Tese (Doutorado em Doutorado em Educação) - Universidade Estadual de Campinas, 2009.

STUDART, D. C. A produção intelectual do CECA-Brasil nas conferências internacionais do Comitê de Educação e Ação Cultural do ICOM de 1996 a 2004. Musas - Revista de museus e Museologia. v.1, n.1. Rio de Janeiro: IPHAN, p. 11$18,2004$.

; AlMEIDA, A.; VALENTE, M. E.. Pesquisa de público em museus: desenvolvimento e perspectivas. In: GOUVÊA, G.; MARANDINO, M.; LEAL, M. C. Educação e Museu: a construção social do caráter educativo dos museus de ciências. Rio de Janeiro: Access, 2003, p. 129 - 160.

TEDDLIE, CH., \& TASHAKKORI, A. Foundations of Mixed Methods Research: Integrating Quantitative and Qualitative Approaches in the Social and Behavioral Sciences. Thousand Oaks, CA: Sage, 2009, 387p.

TEIXEIRA, A.R. Resenha histórica do Instituto de Botânica de São Paulo. Ciência e Cultura, v.40, p. 1045-1054, 1988.

THOMAS, K. 0 Homem e o Mundo Natural: mudanças de atitude em relação às plantas e aos animais (1500-1800), São Paulo: Cia das Letras, 1983, 537p.

TRAJANO, E. Políticas de conservação e critérios ambientais: princípios, conceitos e protocolos. Estudos Avançados. vol.24 no.68, São Paulo, 2010.

TUFFANI, M. Após fundir ciência e comunicação, Temer junta secretarias de inclusão e políticas. Direto da Ciência, 2016 disponível em: http://www.diretodaciencia.com/2016/06/30/apos-fundir-ciencia-ecomunicacoes-temer-junta-secretarias-de-inclusao-e-de-politicas/ Acesso em: 01 abr. 2017.

ULBRICH K, SETTELE J, BENEDICT FF (eds). Biodiversity in Education for Sustainable Development - Reflection on School-Research Cooperation. Pensoft Publishers, Sofia-Moscow, 2010, 149p. 
VALLE, A. L. R. 10 referências sobre educação em museus 16. set/Artes Educação Humanidades Links para referências. Livros. 2014. http://pitacodemia.com/10-referencias-sobre-educacao-em-museus/Educação e Pesquisa acesso em 15 abr. 2017.

VAN PRAET, M.; DAVALLON, J. e JACOBI, D.: Três olhares de além-mar: o museu como espaço de divulgação da ciência. (Entrevistas concedidas a Luciana Sepúlveda Koptcke e Luisa Massarani). História, Ciências, Saúde - Manguinhos, v. 12 (suplemento), p. 349-64, 2005.

VIGOTSKY, L. Pensamento e linguagem. São Paulo, Martins Fontes, 1996, 194p.

VILCHES, A.; GIL-PÉREZ, D.; GONZÁLEZ, M. e GONZÁLEZ, E. La atención a la situación de emergencia planetaria en los museos de ciencias: el Inicio de un cambio necesario. Ciência\&Educação, v.12, n. 1, p. 39-55, 2006.

WILLISON, J. Education for Sustainable Development: Guidelines for Action in Botanic Gardens. Botanic Gardens Conservation International, Richmond, Reino Unido, 2006, 25p.

YOUNG, M. Para que servem as escolas? Educação \& Sociedade, v. 28, n. 101, p. 1287-1302, 2007.

. O futuro da educação em uma sociedade do conhecimento: argumento radical em defesa de um currículo centrado em disciplinas. Revista Brasileira de Educação. São Paulo, v. 19, n. 48, p.609-623, 2011. 


\section{Anexos}

\section{A. Roteiro de observação da exposição}

\begin{tabular}{|c|c|}
\hline Ficha & técnica \\
\hline Instit & içãa \\
\hline Títul & da exposição \\
\hline Tem & \\
\hline Loca & zação da exposição na instituição \\
\hline Cura & oria/equipe principal \\
\hline Ano & e inauguração \\
\hline Instit & ição/setor responsável pela manutenção \\
\hline Instit & ição/setor responsável pelo educativo \\
\hline & $\begin{array}{l}\text { sta conceitual } \\
\text { lagem epistemológica) }\end{array}$ \\
\hline $1.1-$ & $\begin{array}{l}\text { ientífica } \\
\text { Temática geral da exposição } \\
\text { Subtemas abordados nos espaços } \\
\text { Conceitos e conteúdos abordados } \\
\text { Relação entre os conceitos e conteúdos }\end{array}$ \\
\hline $1.2-$ & $\begin{array}{l}\text { Museográfica } \\
\text { Tipos de objetos (científicos, históricos ou de divulgação ou hands on, minds on, hearts } \\
\text { on...) } \\
\text { Tipos de textos (científicos, didáticos, de divulgação ou de museus; acadêmico/não } \\
\text { acadêmico; interdisciplinar/intradisciplinar) } \\
\text { Tipos de imagem } \\
\text { a) técnica de produção (fotos, desenho ilustrativo, esquemas, mapas, tabelas) } \\
\text { b) tipo de estrutura (naturalística, realística, conceitual, abstrata etc.) }\end{array}$ \\
\hline $1.3-$ & $\begin{array}{l}\text { ducacional/Comunicacional (informacional? Dialógica?) } \\
\text { papel da texto } \\
\text { papel do objeto } \\
\text { papel da imagem } \\
\text { papel do público } \\
\text { papel do mediador? }\end{array}$ \\
\hline Espa & o expositivo \\
\hline $\begin{array}{l}\text { Desc } \\
\text { apar }\end{array}$ & $\begin{array}{l}\text { ção geral a partir da planta baixa (presença de percurso principal, módulos/subtemas, } \\
\text { tos e painéis) }\end{array}$ \\
\hline & $\begin{array}{l}\text { tos ambientais } \\
\text { iluminação natural alta } \\
\text { iluminação artificial ambiental e de acento (objetos, arquitetura do edifício etc.) } \\
\text { climatização adequada à arquitetura } \\
\text { adequada ao uso expositivo } \\
\text { segurança (equipamentos e sinalização e esta em compatibilidade com a da exposição) } \\
\text { sinalização com fins expositivos (uso de cores, setas de percurso, identificação de } \\
\text { módulos etc.) }\end{array}$ \\
\hline
\end{tabular}




\begin{tabular}{|l|}
\hline \multicolumn{1}{|c|}{$\cdot \begin{array}{l}\text { mobilidade (espaços adequados as paradas de observação e manutenção do fluxo) } \\
\text { acessibilidade }\end{array}$} \\
\hline $\begin{array}{l}\text { Aspectos de conservação e segurança (conservação do espaço, objetos, aparatos, painéis e } \\
\text { funcionalidades; manutenção da mobilidade; segurança) }\end{array}$ \\
\hline Linguagens da exposição (descrição) \\
\hline Textos \\
\hline Objetos (biológicos, modelos, históricos) \\
\hline Suportes interativos, mecanismos/eletrônicos \\
\hline imagens, gráficos e infográficos \\
\hline \\
\hline Intenção do uso do espaço pelo público e interação com linguagens \\
\hline Descrição da funcionalidade do percurso previsto \\
\hline Interação com objetos e aparatos (localização, altura, procedimentos de operação) \\
\hline $\begin{array}{l}\text { Interação com textos e painéis } \\
\text { (tamanho dos textos, da letra, altura para leitura, presença e localização de elementos gráficos } \\
\text { de apoio) }\end{array}$ \\
\hline \\
\hline Outros materiais \\
\hline Catálogos/impressos/mapa-guia \\
\hline Recursos Complementares \\
\hline Comentários \\
\hline
\end{tabular}




\section{B. Roteiro de entrevista}

Instrumento de coleta de dados $\mathbf{1}$ - Roteiro de entrevista para conceptores das exposições com lembrança estimulada via imagens da exposição

A ser aplicado junto aos membros da instituição museal envolvidos com a concepção das exposições.

Objetivo: levantar as seleções, escolhas, formas de participação, conteúdos e relações entre os agentes que atuaram na produção do discurso pedagógico.

\section{Aos elaboradores e/ou coordenadores das exposições analisadas}

Nome da Instituição:

Nome do/a Entrevistado/a:

Ocupação:

Formação:

Data:

\section{I.I) Vínculo Institucional:}

1) Que tipo de vínculo você possui com a Instituição?

2) Como se deu seu envolvimento com a Exposição?

3) Qual seu papel nas etapas de desenvolvimento da Exposição?

\section{II) Elaboração da Exposição:}

4) Como surgiu a ideia da exposição? Como foi viabilizada?

5) Quem (pessoa/instituição) participou deste primeiro momento da concepção?

6) Qual o seu nível (ideias, decisões, coordenação) de participação neste momento?

7) Havia algum tipo de contrapartida para alguma instituição? Em caso positivo:

a) Quais instituições?

b) Que tipo de contrapartida (número de público, temática, participação na elaboração, montagem ou gestão)?

8) Como a exposição foi elaborada (equipe - permaneceu a mesma desde a concepção da exposição, organização interna, prazos, custos etc.)?

9) De que trata a exposição? Qual o seu tema? 
10) Por quê este tema foi escolhido?

11) Quais eram os principais objetivos da exposição? Eles se mantiveram ao final do processo? (perguntar sobre os objetivos educacionais, caso não apareça na fala)

12) Quais acervos foram considerados para ser objetos da Exposição?

a) Eles foram coletados em função dos conteúdos, expografia e/ou disponibilidade?

b) No último caso (disponibilidade), a seleção de objetos interferiu nos conteúdos e expografia?

13) Como foi escolhido o espaço expositivo?

14) Que tipo de infraestrutura foi pensada para a exposição (mobiliário, suportes, iluminação, cores básicas etc.)? Todas as equipes participaram dessas escolhas? Em caso negativo, quais equipes participaram?

15) Quais linguagens de apoio foram pensadas para exposição (textos, etiquetas, painéis, ilustrações, recursos gráficos, eletrônicos etc.)? Todas as equipes participaram dessas escolhas? Em caso negativo, quais equipes participaram?

16) Foi elaborado um roteiro expositivo? Quem esteve envolvido neste processo? Você julga que todas as equipes tiveram autonomia para participar deste processo?

17) Como foi elaborado o discurso expositivo? Quais as características dos textos elaborados para a exposição?

18) Há um público alvo da exposição? Ele foi escolhido desde a concepção dela?

19) Há algum documento que tenha servido de referencia para a concepção da exposição do ponto de vista museográfico e expográfico (manuais museografia, expografia)?

20) Houve consulta a algum documento oficial sobre conteúdos das áreas específicas?

21) Houve consulta a documentos oficiais de educação ou educação em museus (PCN, LDB, IBRAM)?

\section{III) Execução da Exposição}

22) Todas as etapas do planejamento foram colocadas em prática?

a) Em caso positivo, como isso foi feito? Quais foram as etapas? 
b) Em caso negativo, quais as etapas que não foram realizadas? Por que isso ocorreu?

23) Foram produzidos materiais de apoio ou catálogos para exposição? Em caso positivo, com que objetivo? Para que público?

24) Houve divulgação da exposição? Em quais mídias? Para qual público? Com que objetivo?

\section{IV) Análise sobre os conteúdos da exposição}

25) Qual seria a proposta conceitual da exposição?

26) Como esta proposta foi elaborada (quem participou, objetivos)

27) Foram realizadas pesquisas prévias sobre a temática da exposição junto ao público da instituição? De que tipo?

28) Foram consultados pesquisadores da instituição e de outras instituições?

a) Qual o objetivo desta consulta?

b) Como ela foi feita (via e-mail, conversas, entrevistas),

c) Quais profissionais participaram (área de atuação)?

29) Realizou-se levantamento bibliográfico? Em quais tipos de suporte? Com quais objetivos?

OBS: temas atuais na divulgação cientifica, livros didáticos, outros materiais - podem indicar que houve uma tentativa de aproximação com conhecimento prévio/educação; verificar se houve consulta a artigos de educação em museus

30) Como foi a seleção de conteúdos e conceitos abordados na exposição? Quem participou desta seleção? Por quê estes conteúdos foram escolhidos?

OBS: tentar fazer vinculo com os pesquisadores consultados, caso houver, levantamento bibliográfico (acadêmico, não acadêmico), poder de decisão dos envolvidos.

31) Há conteúdos essenciais para a compreensão da temática principal da exposição e que não poderiam ser deixados de fora? Você considera que há unanimidade em relação a estes conteúdos entre os especialistas da área?

32) Como você diria que se dá a relação entre as pesquisas existentes sobre o conhecimento específico e a sua apresentação na exposição?

33) Estão presentes na exposição temas ou conceitos científicos atuais? Por quê?

34) Você considera a exposição atual, do ponto de vista científico? Por quê? 
35) Do ponto de vista museográfico (explicar o que é), como você percebe a atualidade da exposição?

OBS: questão da imersão, aparatos interativos, comunicação visual

36) Foram percebidas dificuldades na apresentação de algum dos temas abordados na exposição? Quais? Por que?

\section{I.V) Compreensão Do Público}

37) Na sua opinião, o público compreende a proposta conceitual da exposição? Por quê isso ocorre?

38) Você considera que as escolhas e seleções (conteúdos, mobiliário, suportes, interativos) realizadas na concepção da exposição influenciam a forma como o público percebe a exposição?

OBS: Dar exemplos como a escolha do tema principal, conteúdos e sua complexidade, apresentar conhecimento acadêmico (usar também a resposta da questão da compreensão conceitual pelo público), ser uma exposição de imersão, escolha dos objetos, expografia. Como?

39) De forma geral, você considera que ocorre aprendizagem na exposição? De quais dimensões de conteúdos (conceitos, procedimentos, habilidades, atitudes, valores)?

\section{VI) Avaliação da Exposição:}

40) A exposição já passou por algum tipo de avaliação?

a) Em caso positivo, de que tipo? Com que objetivos? Foi proposto algum tipo de reformulação?

b) Em caso negativo, por quê?

41) Qual o público que mais visita a exposição? Você saberia dizer a razão disso?

42) Quais são, na sua opinião, os pontos positivos, os elementos fortes da exposição? Por quê?

43) Em que aspectos que você a considera frágil? Por quê?

44) Você proporia algum tipo de modificação na exposição? Por quê?

45) Em sua opinião, o público aprende os conceitos tratados na exposição? Por quê? 